\title{
THE ROLE OF SALT IN THE STRUCTURAL DEVELOPMENT OF CENTRAL UTAH
}

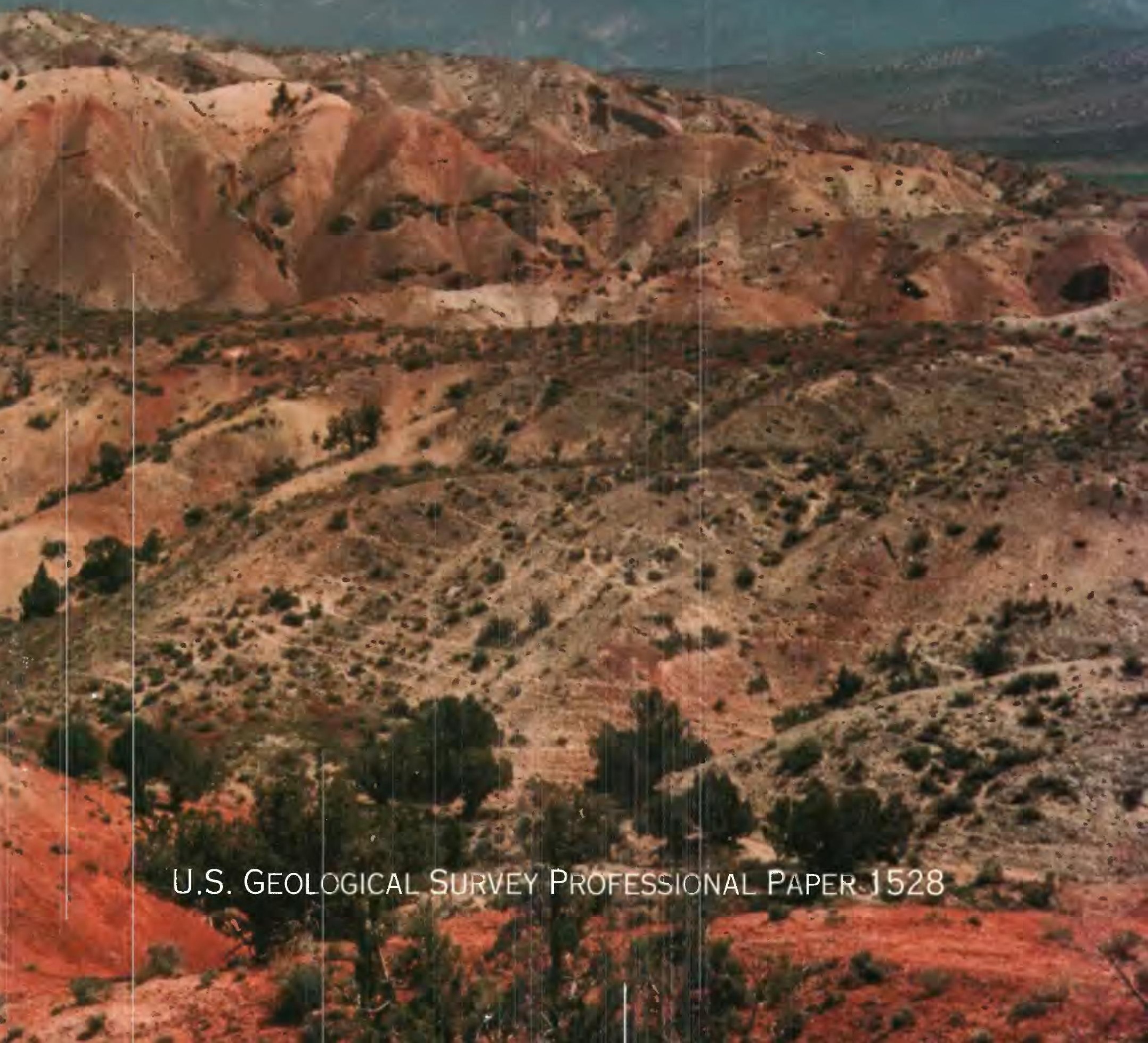




\section{AVAILABILITY OF BOOKS AND MAPS OF THE U.S. GEOLOGICAL SURVEY}

Instructions on ordering publications of the U.S. Geological Survey, along with prices of the last offerings, are given in the current-year issues of the monthly catalog "New Publications of the U.S. Geological Survey." Prices of available U.S. Geological Survey publications released prior to the current year are listed in the most recent annual "Price and Availability List." Publications that may be listed in various U.S. Geological Survey catalogs (see back inside cover) but not listed in the most recent annual "Price and Availability List" may no longer be available.

Reports released through the NTIS may be obtained by writing to the National Technical Information Service, U.S. Department of Commerce, Springfield, VA 22161; please include NTIS report number with inquiry.

Order U.S. Geological Survey publications by mail or over the counter from the offices listed below.

\section{BY MAIL}

\section{Books}

Professional Papers, Bulletins, Water-Supply Papers, Techniques of Water-Resources Investigations, Circulars, publications of general interest (such as leaflets, pamphlets, booklets), single copies of Earthquakes \& Volcanoes, Preliminary Determination of Epicenters, and some miscellaneous reports, including some of the foregoing series that have gone out of print at the Superintendent of Documents, are obtainable by mail from

\section{U.S. Geological Survey, Map Distribution Box 25286, MS 306, Federal Center Denver, CO 80225}

Subscriptions to periodicals (Earthquakes \& Volcanoes and Preliminary Determination of Epicenters) can be obtained ONLY from the

\section{Superintendent of Documents Government Printing Office Washington, DC 20402} Documents.)

(Check or money order must be payable to Superintendent of

\section{Maps}

For maps, address mail orders to

$$
\begin{aligned}
& \text { U. S. Geological Survey, Map Distribution } \\
& \text { Box 25286, Bldg. 810, Federal Center } \\
& \text { Denver, CO } 80225
\end{aligned}
$$

Residents of Alaska may order maps from

\author{
U.S. Geological Survey, Earth Science Information Center \\ 101 Twelfth Ave., Box 12 \\ Fairbanks, AK 99701
}

\section{OVER THE COUNTER}

\section{Books and Maps}

Books and maps of the U.S. Geological Survey are available over the counter at the following U.S. Geological Survey offices, all of which are authorized agents of the Superintendent of Documents.

- ANCHORAGE, Alaska-Rm. 101, 4230 University Dr.

- LAKEWOOD, Colorado-Federal Center, Bldg. 810

- MENLO PARK, California-Bldg. 3, Rm. 3128, 345 Middlefield Rd.

- RESTON, Virginia-USGS National Center, Rm. 1C402, 12201 Sunrise Valley Dr.

- SALT LAKE CITY, Utah-Federal Bldg., Rm. 8105, 125 South State St.

- SPOKANE, Washington-U.S. Post Office Bldg., Rm. 135, West 904 Riverside Ave.

- WASHINGTON, D.C.-Main Interior Bldg., Rm. 2650, 18th and C Sts., NW.

\section{Maps Only}

Maps may be purchased over the counter at the following U.S. Geological Survey offices:

- FAIRBANKS, Alaska-New Federal Bldg, 101 Twelfth Ave.

- ROLLA, Missouri-1400 Independence Rd.

- STENNIS SPACE CENTER, Mississippi-Bldg. 3101 


\section{The Role of Salt in the Structural Development of Central Utah}

By IRVING J. WITKIND

U.S. GEOLOGICAL SURVEY PROFESSIONAL PAPER 1528

Multiple episodes of diapirism, probably salt-generated, have determined the structural pattern of central Utah. The causative salt and other evaporites are integral components of the Arapien Shale of Middle Jurassic age, one of the most unusual stratigraphic units in central Utah

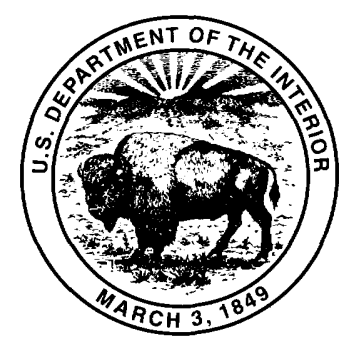




\title{
U.S. DEPARTMENT OF THE INTERIOR BRUCE BABBITT, Secretary
}

\author{
U.S. GEOLOGICAL SURVEY
}

Gordon P. Eaton, Director

\begin{abstract}
Any use of trade, product, or firm names in this publication is for descriptive purposes only and does not imply endorsement by the U.S. Government.
\end{abstract}

\section{Library of Congress Cataloging-in-Publication Data}

Witkind, Irving Jerome, 1917-

The role of salt in the structural development of central Utah / by Irving J. Witkind.

p. $\quad$ cm.-(U.S. Geological Survey professional paper ; 1528)

Includes bibliographical references.

Supt. of Docs. no.: I 19.16: 1528

1. Diapirs-Utah. 2. Salt domes-Utah. 3. Geology, Structural-Utah. 4. Geology, Stratigraphic-Jurassic. 5. Arapien Shale (Utah). I. Title. II. Series.

QE75.P9 no. 1528

[QE606.5.U6]

$557.3 \mathrm{~s}-\mathrm{dc} 20$

[551.8 7 ]

$92-15520$

CIP

For sale by USGS Map Distribution

Box 25286, Building 810

Denver Federal Center

Denver, CO 80225 


\section{CONTENTS}

Abstract

Introduction

Previous work

Current work

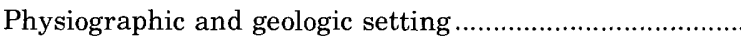

Middle Rocky Mountains province Southern Wasatch Range.....

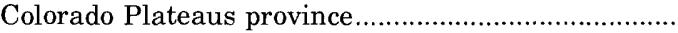
Wasatch Plateau .......................................................

Sanpete-Sevier Valley area ....................................

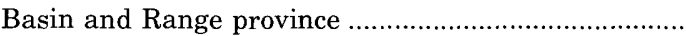
Great Basin section.

Disturbed zone

Definitions.

Stratigraphy

General stratigraphy

The Arapien Shale

Nomenclature

Twist Gulch Formation.

Arapien Shale (geologic aspects)

Lithology

Contact relations...

Lower contact

Upper contact

Areal extent

Arapien embayment and the Arapien basin..

Contained salt

Lithology

Thickness of salt.

Age

Diapiric structures

Intrusive aspects of the Arapien Shale

Minor structures

Thistle area

Dome near ancestral Willow Creek

Red Knolls area.

Cuesta north of Redmonc

Hogbacks in eastern Sevier Valley

Small hill near Ninemile Reservoir

Major structures (diapiric folds).

Sanpete-Sevier Valley diapiric fold...

Red Rocks Sixmile Canyon area..

Red Rocks area

Sixmile Creek canyon area ............................ 48

Wales Gap ................................................. 50

Ancestral Willow Creek area.................................. 51

Geologic setting ….......................................... 51

Discussion .................................................... 51

Gunnison Reservoir area .................................... 55

Redmond diapiric fold..
Diapiric structures-Continued

Major structures-Continued

Sevier Bridge Reservoir diapiric fold ......................... 57

Geologic setting.................................................. 61

Complex structural relations......................... 61

Anomalous depositional thinning................... 63

Red Canyon area (Valley Mountains) ............ 63

Discussion

First diapiric episode...................................... 66

Second diapiric episode .................................. 67

Third diapiric episode ................................... 67

Levan diapiric fold ……............................................. 69

Pigeon Creek area ............................................ 69

Gardner Canyon-Red Canyon area ..................... $\quad 70$

Gardner Canyon area.................................... $\quad 70$

Red Canyon area (southern Wasatch Range) 75

Skinner Peaks area ....................................... $\quad 75$

Pole Creek diapiric fold ............................................... 77

Geologic setting.................................................. 77

KOA Campground area.................................. 77

Middle Fork Pole Creek .................................. 77

Discussion ….......................................... 81

Footes Canyon diapiric(?) fold..................................... 81

Dry Hollow diapiric fold .............................................. 83

Thistle Creek diapiric(?) fold........................................ 83

Geologic setting................................................. 83

Charleston-Nebo thrust plate ......................... 83

Sedimentary sequence of younger rocks........ 84

Strata north of Spanish Fork Canyon

("Billies Mountain" area) ...................... 84

Strata south and west of Spanish Fork Canyon

Discussion of alternative interpretations ...... $\quad 92$

Faulted terrain .................................. 92

Diapiric deformation ............................... 92

Hjorth Canyon diapiric fold …….................................. 93

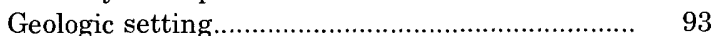

Discussion ........................................................ 95

Little Clear Creek diapiric fold ................................... 96

Geologic setting................................................ 96

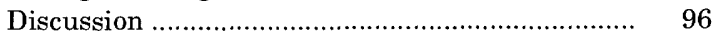

Fairview diapiric(?) fold ........................................ 98

Geologic setting................................................. 98

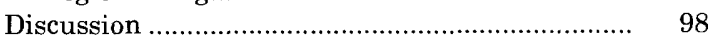

West Hills diapiric(?) fold ......................................... 100

Geologic setting......................................... 100

Discussion ........................................................... 101

Valley Mountains diapiric(?) fold ................................ 101

Geologic setting.............................................. 101

Discussion ....................................................... 102

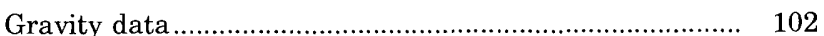


Diapiric deformation of the east flank of the Charleston-Nebo

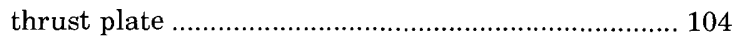

Implications of the tilted strata ................................... 104

Drag along normal fault or faults .......................... 105

Movement along the Wasatch fault zone .............. 105

Uneven compaction of unconsolidated North Horn

Formation and younger sediments.................... 105

Uplift as a result of salt diapirism ........................ 105

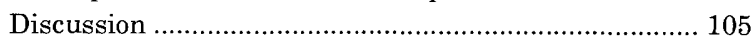

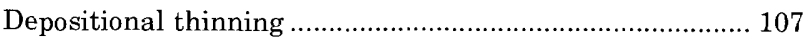

Sanpete-Sevier Valley diapiric fold ............................. 109

Sevier Bridge Reservoir diapiric fold ............................ 109

Pole Creek diapiric fold ................................................... 111

Thistle Creek diapiric fold ............................................ 111

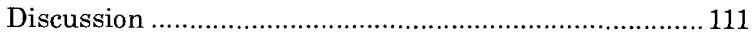

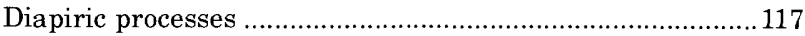

Growth and collapse of diapiric folds..............................117

Growth of diapiric folds........................................117

Slow upwelling................................................119

Rapid, upward, forceful surges........................119
Page

Diapiric processes-Continued

Growth and collapse of diapiric folds-Continued

Collapse of diapiric folds ..................................... 119

Paired, facing monoclines ............................... 121

Diapiric stages and episodes........................................ 124

Geologic pattern .......................................................... 125

Cyclical aspects....................................................... 129

Localization and causative forces .................................... 129

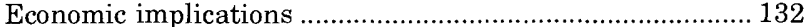

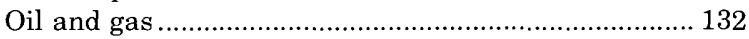

Source beds..................................................... 132

Mancos Shale ........................................... 132

Manning Canyon Shale ................................. 132

Arapien Shale .................................................... 133

Reservoir beds ................................................... 133

Potential traps................................................... 133

Salt-bearing and younger strata ..................... 133

Pre-salt strata ............................................... 134

Overthrust belt and salt diapirs...................... 134

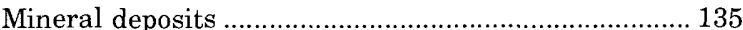

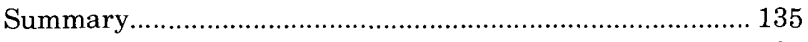

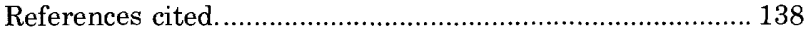

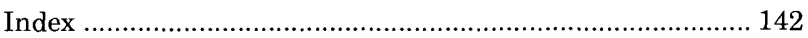

\section{ILLUSTRATIONS}

FIGURE 1. Map showing physiographic provinces in central Utah

2. Index map of central Utah

3. Index map showing sites of geologic maps.

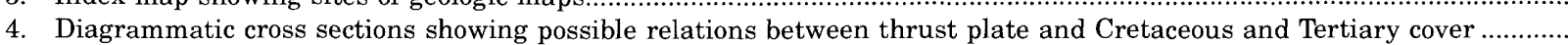

5. Cross section of diapiric fold.

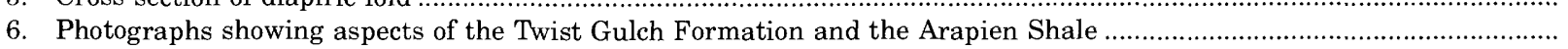

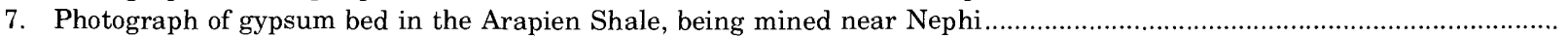

8. Map showing distribution of Arapien Shale exposures

9. Map showing location of major test wells in central Utah, and their spatial relation to recognized diapiric folds ..............

10. Photographs of deformed beds of the Arapien Shale.

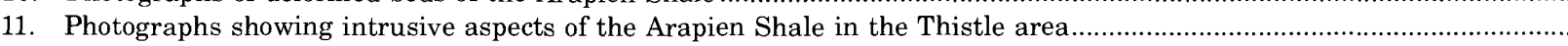

12. Geologic map and cross section of an intrusive mass of Arapien Shale in the ancestral Willow Creek area..

13. Geologic map of the Red Knolls area

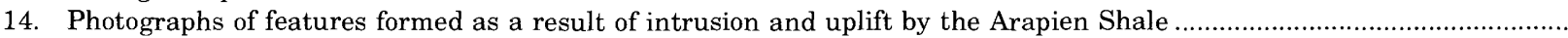

15. Geologic map and cross section of an isolated hill near Ninemile Reservoir

16. Map showing distribution pattern of major diapiric folds.....

17. Photographs showing deformation along east flank of Gunnison Plateau

18. Photographs and annotated sketch of Red Rocks area.

19. Geologic map and cross section of Red Rocks area.

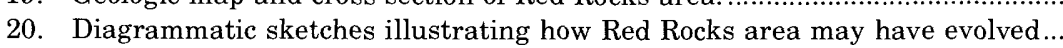

21. Geologic map and cross section of Sixmile Creek canyon area, and annotated sketch of north valley wall, Sixmile Creek canyon

22. Diagrammatic sketches illustrating how Sixmile Creek canyon area may have evolved.

23. Photographs of overturned strata as exposed along east flank of Gunnison Plateau.........

24. Geologic map and cross section near Wales Gap........

25. Diagrammatic sketches illustrating how Wales Gap area may have evolved...........

26. Photographs of cuestas in the ancestral Willow Creek area......

27. Geologic map of ancestral Willow Creek area, and diagrammatic sketches illustrating how area may have evolved ...........

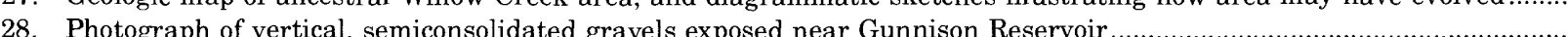

29. Photographs of complex geologic relations along northeast flank of Valley Mountains, near Yuba Dam..........................

30. Geologic map of northeast flank of Valley Mountains, and diagrammatic sketches illustrating how area may have evolved. 
FiguRE 31. Photograph and annotated sketch of Red Canyon area, Valley Mountains

32. Diagrammatic sketches illustrating how Red Canyon area, Valley Mountains, may have evolved

33. Geologic map and cross section of Pigeon Creek area

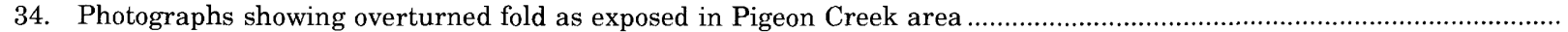

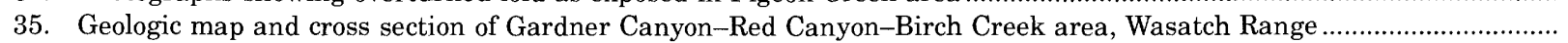

36. Photograph of overturned fold as exposed in Gardner Canyon

37. Photograph of Twin Creek Limestone, Red Canyon, Wasatch Range

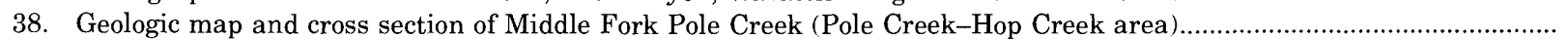

39. Photographs showing geologic relations in and near Middle Fork Pole Creek.....

40. Photographs of complex geologic relations along Hop Creek Ridge and in Hop Creek .

41. Geologic map and cross section of Dry Hollow area

42. Photograph showing angular unconformity between vertical Indianola beds and near-horizontal North Horn strata as exposed near head of Dry Hollow.....

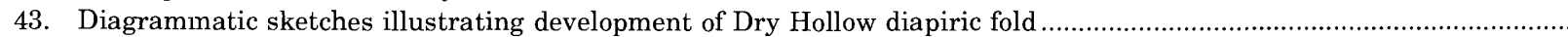

44. Geologic map and cross sections of Thistle area .....

45. Photographs of Thistle area showing relations between the Charleston-Nebo thrust plate and an overlying mantle of Cretaceous and Tertiary rocks.

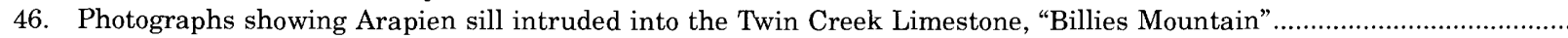

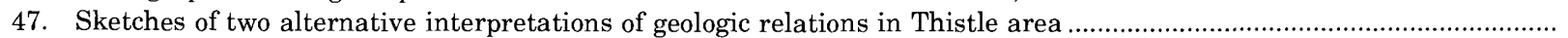

48. Geologic map and cross section, Hjorth Canyon area.....

49. Geologic map and cross sections, Little Clear Creek area

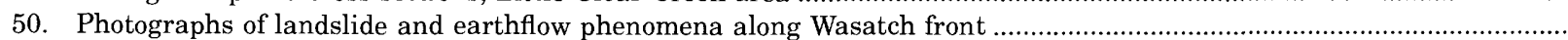

51. Stereographic pair of vertical aerial photographs showing landslide block on which Mormon temple at Manti is built...

52. Bouguer gravity map of central Utah on which axes of major diapiric folds are superimposed...

53. Photographic overviews of localities adjacent to Charleston-Nebo thrust plate........

54. Geologic map of Salt Creek area...

55. Geologic map of Black Canyon area.

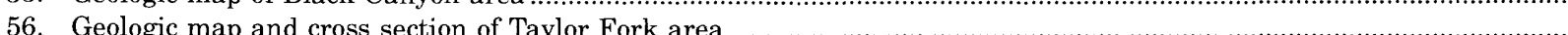

57. Geologic map and cross section of Red Lake area......

58. Geologic map and cross section of Payson Canyon and Bennie Creek area

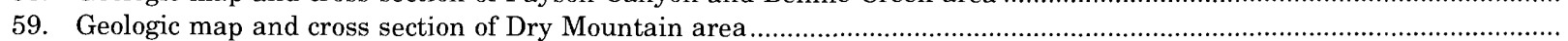

60. Diagrammatic cross sections illustrating two alternative interpretations of how diapiric folds may fail ........................

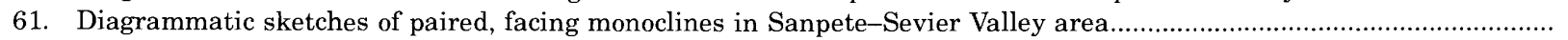

62. Diagrammatic cross sections showing suggested geologic relations along both east and west flanks of Gunnison Plateau

63. Diagrammatic cross sections illustrating pattern of repeated growth and collapse of diapiric folds during three major diapiric episodes

64. Diagrammatic cross section illustrating how extent of erosion can influence interpretation of a geologic pattern

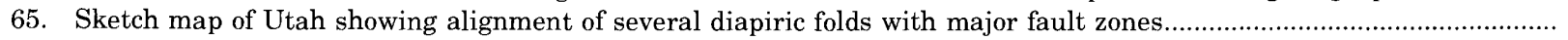

66. Geologic map and cross sections near "Redmond silver mine"

Page 66

\section{TABLES}

TABLE 1. Some stratigraphic units exposed in the Sanpete-Sevier Valley area, central Utah

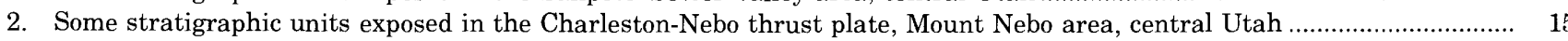

3. Correlation chart for some Middle Jurassic formations in central Utah... 


\title{
THE ROLE OF SALT IN THE STRUCTURAL DEVELOPMENT OF CENTRAL UTAH
}

\author{
By IRVING J. WITKIND
}

ABSTRACT

Multiple episodes of salt diapirism can explain the complex structural history of central Utah. Previous workers in that area have ascribed the intense localized deformation between the Colorado Plateaus and the Basin and Range provinces either to multiple episodes of orogeny, or to repeated mobilization of plastic mudstones. An alternative interpretation, offered here, is that salt, contained within the Arapien Shale of Middle Jurassic age, has been moving continuously almost since it was deposited. Some of this movement has been a slow upwelling, but at times this slow upwelling appears to have been disrupted by sudden and sporadic upward surges of the salt during which the calcareous mudstones and gypsiferous shaly siltstones of the Arapien have been forced upward. They, in turn, have bowed up and folded back the overlying younger sedimentary strata to form elongate, narrow, saltcored anticlines (here termed diapiric folds). These upwarps are fan-shaped in cross section, and are as much as 100 kilometers (60 miles) long. I view the Arapien Shale, thus, as an intrusive sedimentary unit; and the contacts between it and the overlying consolidated sedimentary rocks, described by others in the past as strip-thrusts or unconformities, I consider as chiefly intrusive.

The salt has surged upward repeatedly, and time and again has been removed chiefly by extrusion or dissolution, causing the folds to fail. This cyclical growth and subsequent failure of the diapiric folds has occurred at least three times; each time the reactivated younger folds occupied the same sites and had the same trends as the previous older folds. This pattern, involving the growth and collapse of discrete diapiric folds, is here called a diapiric episode, and each episode is arbitrarily divided into three stages:

1. An intrusive stage during which the salt surges upward and forces the Arapien mudstones to deform the overlying sedimentary rocks into a diapiric fold.

2. An erosional stage during which the removal of the salt results in failure of the fold. Subsequent erosion removes the collapsed and brecciated remnants of the fold leaving a widespread surface of low relief.

3. A depositional stage during which younger sediments are deposited across this newly cut surface.

As the sedimentary units either wedge out or thin along the flanks of these folds, it is probable that the salt, during this stage, was slowly rising and gradually forcing up the overlying strata to form a barrier-in essence, a paleo-high. In those localities where the sedimentary units pass over the crests of the folds, the strata, invariably, are anomalously thin and represent the youngest parts of the formations. Seemingly, the slowly growing barrier was not high enough to block deposition completely, but was able to restrict it. The depositional stage ends with a renewed surge of salt, marking the intrusive stage of the next diapiric episode.

This repeated movement of the Arapien suggests that it has different "ages." Its depositional age is Middle Jurassic; it contains Middle Jurassic fossils. It has several emplacement ages-different geologic ages of movement-each reflecting an upward surge of salt.

Although tenuous evidence suggests that the first major diapiric episode occurred prior to Late Cretaceous time, possibly during the Late Jurassic, the earliest recognizable diapiric episode began in Late Cretaceous time and probably extended into the early Paleocene. A second episode began then and lasted into the late(?) Oligocene, or possibly the Miocene. The third major episode began in the late(?) Oligocene (or Miocene) and persisted into the Pliocene or Pleistocene. A minor diapiric episode may have occurred during the late Pliocene or Pleistocene; if so, this implies that the salt diapirs that underlie the area may still be active.

I recognize 13 major diapiric folds; of these, many of the smaller folds appear to branch off the larger ones much as distributary streams branch off a major stream. The longest fold appears to be the Sanpete-Sevier Valley diapiric fold, which extends northeastward at least 100 kilometers $(60$ miles) from near Richfield on the south to beyond Fountain Green on the north. Its core, exposed along the east side of Sevier Valley as a continuous belt of Arapien mudstones, is concealed northward beneath the alluvial fill of Sanpete Valley. The Redmond fold, which seems to branch off the south end of the Sanpete-Sevier Valley fold, extends northward about 50 kilometers ( 30 miles) from near Sigurd on the south to near Gunnison on the north. The Levan diapiric fold, possibly the northern extension of the Redmond fold, is about 40 kilometers ( 25 miles) long, and extends northward along the west flank of the Gunnison Plateau. The Levan fold starts near Little Salt Creek; at Salt Creek, near Nephi, the fold appears to split into three branches. The western branch, for which I retain the name Levan fold, extends northward and passes beneath and deforms the 
Charleston-Nebo thrust plate. The eastern branch, known as the Pole Creek diapiric fold (probably about 25 kilometers (15 miles) long), extends northeastward and has determined the structural pattern of Cedar Hills; this branch is probably continuous with the Dry Hollow diapiric fold, of which only about 6 kilometers (4 miles) is exposed near Thistle. The middle branch, which I call the Footes Canyon fold, is concealed for the most part but possibly is about 45 kilometers ( 27 miles) long. It may extend along and deform the east flank of the Charleston-Nebo thrust plate. The Sevier Bridge Reservoir fold extends northwestward about 24 kilometers (15 miles) from near Fayette to near Yuba Dam. Probably the Sevier Bridge Reservoir fold is an offshoot of the Redmond fold.

Other large diapiric folds are partly exposed in the IndianolaThistle area; Little Clear Creek follows the crest of a fold that I refer to as the Little Clear Creek fold, which is about 20 kilometers (12 miles) long. Another fold, the Hjorth Canyon fold, which I estimate to be about 10 kilometers ( 6 miles) long, crops out in Hjorth Canyon, and still a third fold, the Thistle Creek fold (about 20 kilometers (13 miles) long), is near the junction of Thistle and Soldier Creeks. The Thistle Creek fold may be the northern extension of the Footes Canyon fold. Tenuous evidence suggests that another diapiric fold (Fairview diapiric(?) fold) underlies the eastern fork of Sanpete Valley, extending northeastward from near Ephraim to near Indianola. This fold may be as long as 40 kilometers (25 miles). Other diapiric folds may underlie the Valley Mountains (Valley Mountains diapiric(?) fold, about 30 kilometers (19 miles) long), and the West Hills, the southern extension of Long Ridge (the West Hills diapiric(?) fold; about 18 kilometers (11 miles) long).

Arapien mudstones have deformed the eroded upper plate of the Charleston-Nebo thrust fault, which forms the southern Wasatch Range. In places, they have intruded and broken the thrust plate; elsewhere they have bowed it up and arched it. This upper plate, known as the Charleston-Nebo thrust plate, is the lower limb of an overturned, almost recumbent anticline; most of the strata, thus, are overturned.

Collapsed diapiric structures, almost certainly salt-controlled, are along the southwest flank of the Gunnison Plateau between Mellor and Timber Canyons. A small salt plug probably underlies the westward-trending transverse graben that lies along the east margin of the Gunnison Plateau between Dry and Maple Canyons.

The trends of the diapiric folds appear to parallel the major tectonic lineaments, implying some form of structural control. Such control is emphasized by the striking linearity of the diapiric folds and their great lengths; two folds are collinear with major fault zones. Moreover, the cyclical nature of the diapirism also hints at some form of structural control-the same sequence of diapiric episodes can be recognized in many widely separated exposed folds. This suggests that the diapirism is regional in extent, and that all diapirs in the area were reactivated, not only repeatedly, but more or less in unison.

I propose that the salt, under static load, was triggered into movement by reactivation of old well-established faults. The salt, presumably, was deposited in a Middle Jurassic saline Arapien basin that overlay preexisting, deep-seated, fundamental faults. As the salt was buried ever more deeply beneath younger sediments, it was placed under increasing static load. When these ancient faults reactivated, probably in response to regional compressive forces-the Sevier orogeny-in pre-Paleocene time and extensional forces from late(?) Oligocene time on, they broke through both the salt and the overlying beds. The salt and accompanying mudstones, under great confining load, sought relief by surging up the newly formed fault planes, using them as conduits. As a result, these parts of the fault planes were obliterated and in their place were formed a series of long, linear, fan-shaped diapiric folds, the trends and extent of which reflect the trends and extent of the buried faults. Subsequent reactivation of these same ancient faults resulted in renewed movement of the salt and mudstones; predictably the younger diapiric folds followed the same trends and occupied the same sites as the older folds.

As a result of the repeated episodes of salt diapirism, there appears to be a contrast in structural style between an upper sequence of salt-bearing and younger rocks and a lower sequence of older pre-salt rocks. The upper sequence is intensely deformed by the repeated episodes of salt movement; the lower sequence, essentially uninfluenced by the salt, may not be as intensely deformed.

This division of the sedimentary stack into two structurally distinct sequences, as well as the type of structural deformation involved, implies that each sequence may contain specific types of potential oil and gas traps. Potential traps in the intensely deformed (salt-bearing and younger) beds would coincide closely with the salt walls and the upthrust masses of the Arapien. Potential traps in the pre-salt strata would include structures of various sizes and shapes that resulted from a variety of orogenic (compressive) forces; such structures may well be wholly unrelated to those formed in the salt-bearing and younger beds.

Possible source rocks for oil and gas include the Mancos Shale of Late Cretaceous age, the Manning Canyon Shale of Pennsylvanian and Mississippian age, and the Arapien Shale of Middle Jurassic age. Of these, however, the Mancos Shale probably extends no farther west than a north-trending line through Wales, the Manning Canyon Shale is probably supermature, and the Arapien Shale is submature.

Suitable reservoir rocks include the Ferron Sandstone Member of the Mancos Shale, and various sandstone beds in the Emery Sandstone Member of the Mancos Shale of Late Cretaceous age. Degree of fracturing may be more important than inherent primary porosity in determining which units are good reservoir rocks.

Mineral deposits, mainly zinc, were probably derived from saline solutions that appear to have been localized along the contacts between the intrusive Arapien Shale and the country rocks.

\section{INTRODUCTION}

A broad, ill-defined zone, commonly referred to as a transition zone, trends southward through central Utah, separating the Colorado Plateaus province from the Basin and Range province (fig. 1). Within this zone, the stratigraphic units, for the most part, are but gently to moderately folded; locally, however, they are tilted into vertical or overturned attitudes, and form belts of unusual structural complexity. Commonly these structurally complex belts are linear and narrow; some extend for many kilometers. Striking angular unconformities abound within these complex belts, and in places, several such unconformities are exposed in a single outcrop. Surprisingly, these unconformities do not persist for long distances perpendicular to the structurally complex belts. Strata that are separated by an angular unconformity, when traced away from these belts, rapidly approach parallelism and commonly become conformable in distances as short as three-fourths of a kilometer $(1 / 2 \mathrm{mi})$. These singularly complex areas tend to coincide with 
elongate, northward-trending upwarps that dominate the area. Where exposed within these structurally complex areas, an entire sequence of stratigraphic units thins anomalously toward the crest of one of these upwarps, and locally some units in the sequence pinch out against the flanks of the upwarp.

This unusual structural and stratigraphic complexity has attracted geologists since the days of Gilbert and Dutton, and its fascination stems in large part from the fact that the field evidence lends itself to conflicting interpretations. Many workers, both past and present, attribute this localized deformation either to multiple episodes of orogeny (Spieker, 1946, 1949; Standlee, 1982; Lawton, 1985; Villien and Kligfield, 1986), or to mobilization of the plastic mudstone beds of the Middle Jurassic Arapien Shale (Gilliland, 1963). I believe, however, that much of the complexity stems from multiple episodes of salt diapirism-in essence, the repeated growth and collapse of salt-cored anticlines (here called diapiric folds). These folds, of prime importance, have determined both the local and regional structural framework of this sector of central Utah. Major geologic misconceptions are inevitable unless one grasps their significance. Nearly a half-century ago, Stokes (1952, p. 961), referring to salt-generated structures of the Sanpete-Sevier Valley area, wrote: "Caution is suggested in interpreting strong local structures of the sort found in these areas [central Utah] as evidence for orogenic activity." I concur in the strongest possible way.

The causative rock salt (halite) is contained within the Arapien Shale of Middle Jurassic depositional age, and I propose that upward, near-vertical, local

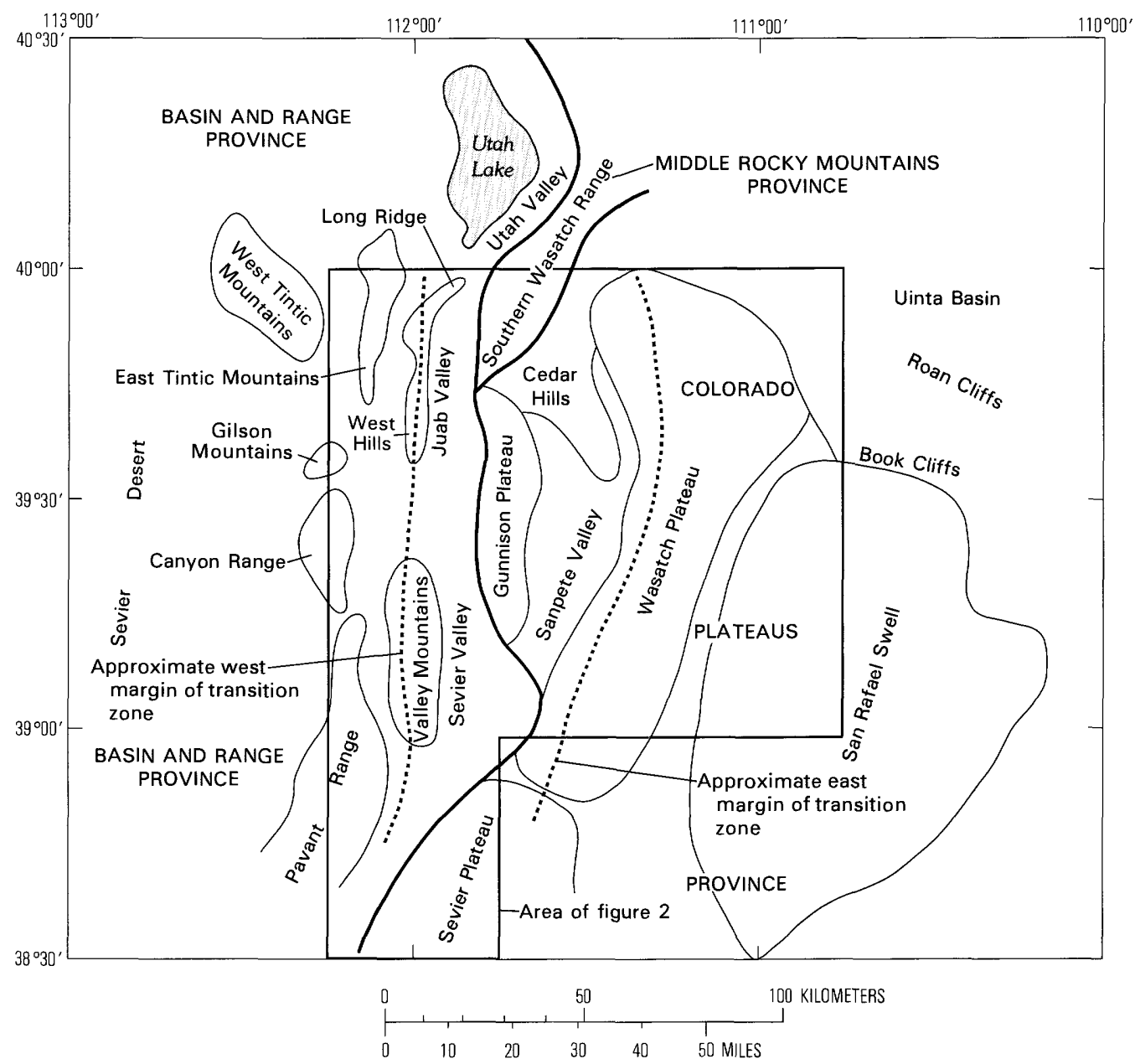

FIGURE 1.-Physiographic provinces in central Utah. Parts of three major physiographic provinces meet in central Utah - the Colorado Plateaus on the east, the Basin and Range on the west, and the Middle Rocky Mountains, represented by the southward-pointing wedge of the southern Wasatch Range, on the north. 


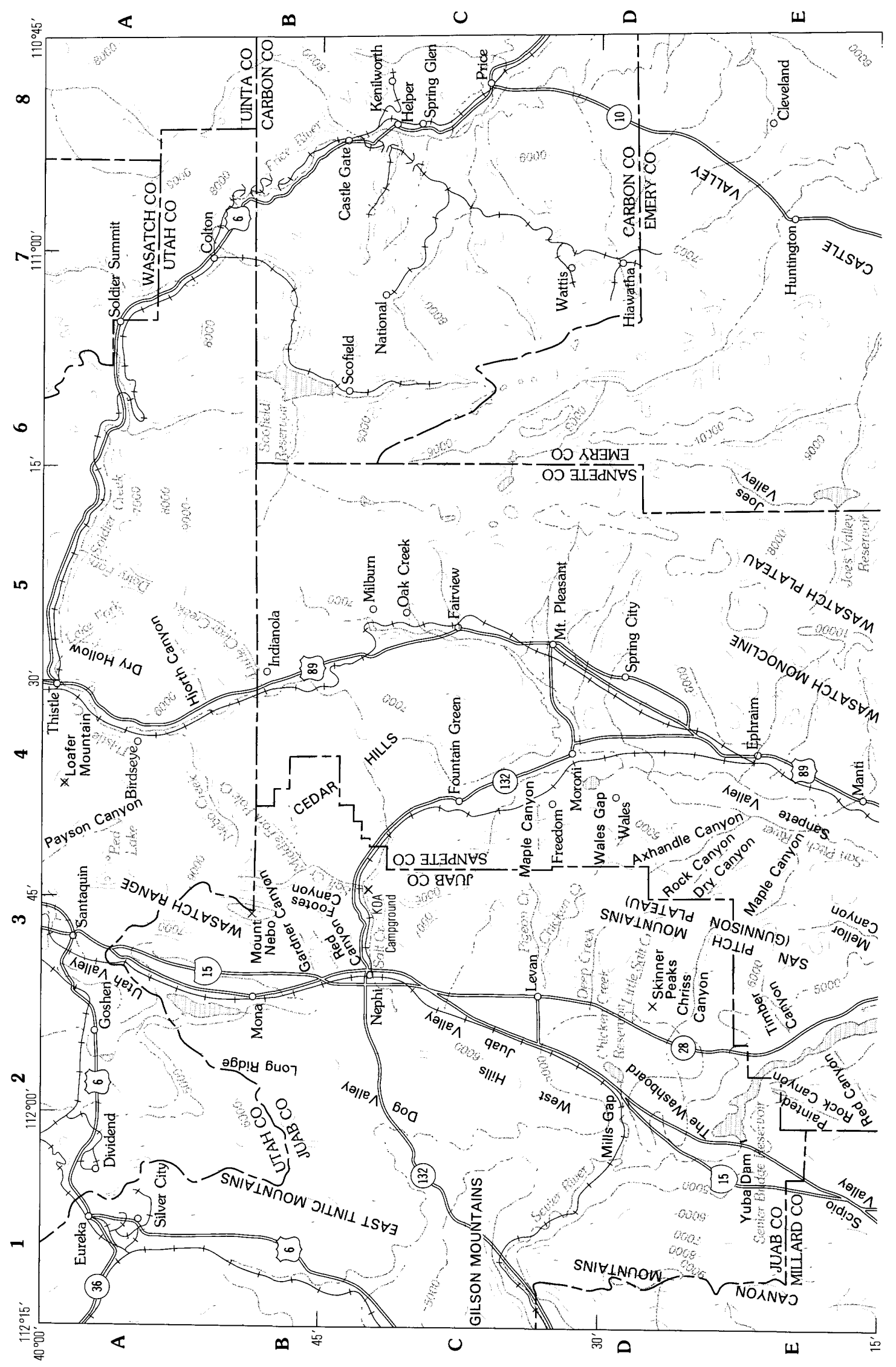


INTRODUCTION

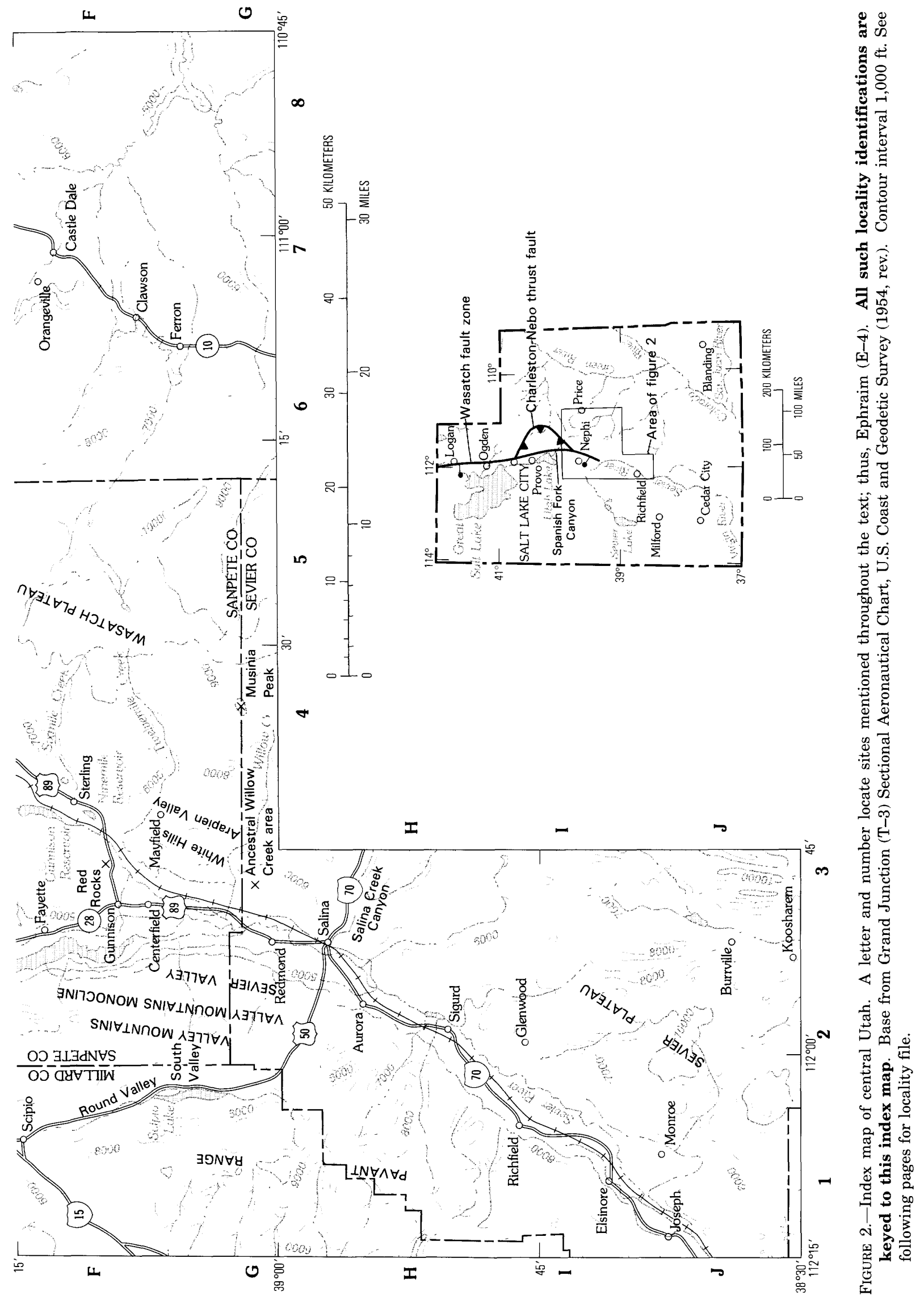


FIGURE 2-Continued.-Locality file for index map of central Utah.

\section{Name}

Ancestral Willow Creek

Arapien Valley

Aurora

Axhandle Canyon

Birdseye

Burrville

Canyon Mountains

Castle Dale

Castle Gate

Castle Valley

Cedar Hills

Centerfield

Chicken Creek Reservoir

Clawson

Cleveland

Colton

Deep Creek

Dividend

Dry Canyon

Dry Hollow

East Tintic Mountains

Elsinore

Ephraim

Eureka

Fairview

Fayette

Ferron

Footes Canyon

Fountain Green

Freedom

Gardner Canyon

Gilson Mountains

Glenwood

Goshen

Gunnison

Gunnison Plateau (San Pitch Mountains)

Gunnison Reservoir

Helper

Hiawatha

Hjorth Canyon

Huntington

Indianola

Joes Valley

Joes Valley Reservoir

Joseph

Juab Valley

Kenilworth

KOA Campground

Koosharem

Lake Fork

Levan

Little Clear Creek

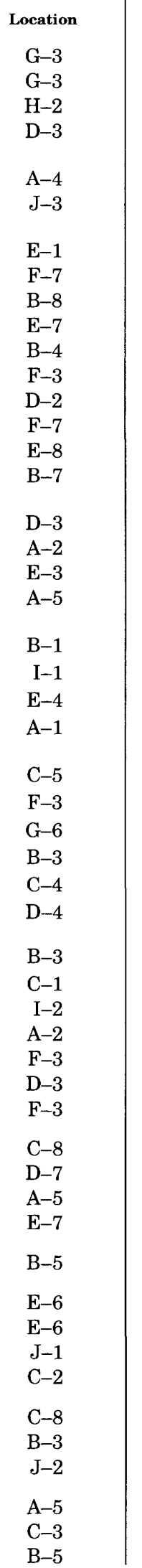

FIGURE 2-Continued.-Locality file for index map of central Utah.

Name

Little Salt Creek

Loafer Mountain

Long Ridge

Manti

Maple Canyon (Northeast flank-Gunnison Plateau)

Maple Canyon (Southeast flank-Gunnison Plateau)

Mayfield

Mellor Canyon

Middle Fork Pole Creek

Milburn

Mona

Monroe

Moroni

Mount Nebo

Mount Pleasant

Musinia Peak

National

Nebo Creek

Nephi

Oak Creek

Orangeville

Painted Rock Canyon

Pavant Range

Pigeon Creek

Pole Creek

Price

Price River

Red Canyon (Valley Mountains)

Red Canyon (Wasatch Range)

Red Rocks

Redmond

Richfield

Rock Canyon

Round Valley

Salina

Salina Canyon (Salina Creek Canyon)

Salt Creek

Sanpete Valley

San Pitch Mountains (Gunnison Plateau)

San Pitch River

Santaquin

Scipio

Scipio Lake

Scipio Valley

Scofield

Scofield Reservoir

Sevier Bridge Reservoir (Yuba Lake)

Sevier Plateau

Sevier River

Sevier Valley

Sigurd

Silver City

Sixmile Canyon (Sixmile Creek canyon)

Soldier Creek
Location

$\mathrm{D}-3$

A-4

B-2

E-4

C-4

E-3

F-3

E-3

B-4

B-5

B-3

J-1

D-4

B-3

D-5

G-4

C-7

B-4

B-3

C-5

F-7

E-2

H-1

C-3

B-4

C-8

B-8

E-2

B-3

F-3

G-3

I-1

E-3

F-2

G-3

$\mathrm{H}-3$

B-3

E-4

D-3

E-4

A-3

F-1

F-2

E-1

B-6

B-6

E-2

J-2

I-2

G-2

$\mathrm{H}-2$

A-1

F-4

A-5 
FIGURE 2-Continued.-Locality file for index map of central Utah.

$$
\text { Name }
$$

South Valley (Valley Mountains)

Southern Wasatch Mountains (Wasatch Range)

Spring City

Spring Glen

Sterling

The Washboard

Thistle

Thistle Creek

Timber Canyon

Twelvemile Creek

Valley Mountains

Valley Mountains monocline

Wales

Wales Gap

Wasatch monocline

Wasatch Plateau

Wasatch Range (Southern Wasatch Mountains)

Washboard, The

Wattis

West Hills

White Hills

Willow Creek

Yuba Dam

Yuba Lake (Sevier Bridge Reservoir)

Location
G-2
A-3
D-5
C-8
F-4
D-2
A-5
A-4
E-3
F-3
G-2
G-2
D-4
D-4
E-5
F-5
A-3
D-2
D-7
D-2
G-3
G-3
E-2
E-2

movements of the buried salt are ultimately responsible for the intense deformation. I am much impressed by the striking similarities between the salt-generated features exposed in the Paradox Basin of southwestern Colorado and southeastern Utah and almost identical features exposed in this sector of central Utah (fig. 2). Stokes (1982), similarly impressed, has proposed the name "Arapien basin" for this salt-rich sector of central Utah.

In this Professional Paper, I bring together many of the data and views that I have published elsewhere, either as articles in scientific journals or as descriptive textual material accompanying geologic maps. This report is thus a synthesis-in essence, a comprehensive discussion in one publication of my views on the role of salt in the structural evolution of central Utah. It might ease the burden of searching for and digging out the pertinent literature even for those who have ready access to modern, well-stocked geologic libraries.

Locations mentioned in the text are keyed to figure 2, the index map of central Utah, by an arbitrary grid placed on the map. Figure 3 shows those areas for which geologic maps have been prepared.

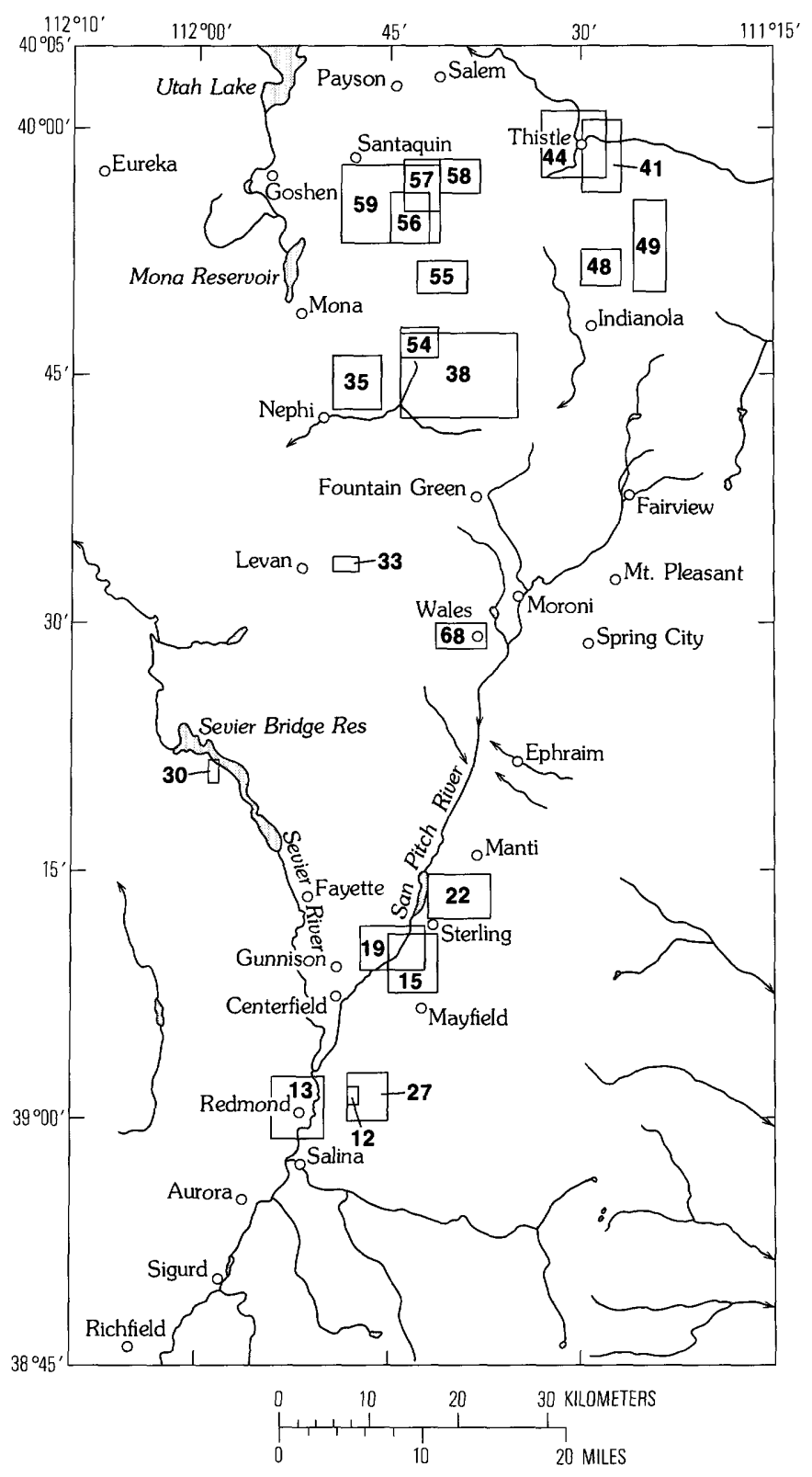

FIGURE 3.--Index map of central Utah showing locations of all geologic maps discussed in this report, listed by illustration number. Figure 12, Intrusive mass of Arapien Shale; 13, Red Knolls area; 15, Hill near Ninemile Reservoir; 19, Red Rocks area; 21, Sixmile Creek canyon area; 27, Ancestral Willow Creek area; 30, Northeast flank of Valley Mountains; 33, Pigeon Creek area; 35, Gardner Canyon-Red Canyon area, Wasatch Range; 38, Middle Fork Pole Creek; 41, Dry Hollow area; 44, Thistle area; 48, Hjorth Canyon area; 49, Little Clear Creek area; 54, Salt Creek area; 55, Black Canyon area; 56, Taylor Fork area; 57, Red Lake area; 58, Payson Canyon and Bennie Creek area; 59, Dry Mountain area. Base from Grand Junction (T-3) Sectional Aeronautical Chart, U.S. Coast and Geodetic Survey (1954, rev.). 


\section{PREVIOUS WORK}

Stokes, in two perceptive abstracts (1952, 1956), first advanced the possibility that the growth and collapse of salt structures might be significant in the structural development of central Utah. Regrettably, he never fully developed his views in the published literature. Because the evidence, on the whole, is inconclusive, Stokes' views initially failed to gain much acceptance. As the search for oil in central Utah led to more and more exploratory drilling, the extent of the Arapien salt became evident, and the importance of salt diapirism in the structural development of central Utah was again emphasized by Christiansen (1963), Eardley (1969), Moulton (1975), and Baer (1976). Baer, in particular, stressed the importance of periodic diapirism in the area, noting that diapirism seemingly had persisted from the Cretaceous through the Pleistocene, and he attributed much of the structural deformation in central Utah to this diapirism. The diapiric concept has gradually gained adherents, and additional papers by workers in central Utah have added to our knowledge. Runyon $(1977 \mathrm{a} ; 1977 \mathrm{~b})$ described collapsed diapirs near Indianola. Hawks (1980) described several diapiric localities in the Cedar Hills, and Taylor (1980) has attributed the deformation in the Sterling area to diapirism. Recently Picard (1980) discussed the stratigraphy and petrography of the Arapien Shale, and speculated about the origin of this salt- and evaporite-rich unit. Hansen (1976) suggested that the beds of salt in central Utah are but part of a much larger Jurassic evaporite belt that extends from southeast Arizona to southeast Idaho.

\section{CURRENT WORK}

I began work in central Utah in 1977 as part of the U.S. Geological Survey's Coal Exploratory Program. By 1979 I had become convinced that salt had played, and continues to play, a dominant role in the structural evolution of central Utah. My views have been offered in a series of maps and papers published in various guidebooks and journals (Witkind, 1981, 1982, 1983, 1986, 1987, 1988, 1992; Sprinkel, Witkind, and Baer, 1982; Witkind and Page, 1984; Witkind, Weiss, and Brown, 1987, and Witkind and Marvin, 1989). Those who oppose the salt-diapiric concept question whether the vast amounts of salt called for by that concept ever did underlie central Utah (Standlee, 1982, p. 376-377).

The existence of concealed salt diapirs in central Utah is inferred to some extent from test-well data, but chiefly from the shapes of the minor and major landforms that extend across this sector of Utah. Although the area has been crisscrossed repeatedly by seismic surveys, all the resultant reflection profiles are proprietary. Chevron USA, Inc., has been kind enough to permit me to examine some of their seismic profiles that cross the Wasatch Plateau and the Sanpete Valley area. The general structural pattern reflected by various of the reflection profiles is perhaps best described as upturned Cretaceous beds overlain by downturned Tertiary strata-a pattern displayed in many surface exposures (p. 121).

\section{PHYSIOGRAPHIC AND GEOLOGIC SETTING}

This sector of central Utah includes parts of three major physiographic provinces: the Middle Rocky Mountains, the Colorado Plateaus, and the Basin and Range (fig. 1). A broad north-trending lowland formed by the collinear alignment of three major valleysUtah, Juab, and Sevier Valleys-effectively divides the area into two unequal sectors. Parts of both the Middle Rocky Mountains and Colorado Plateaus provinces are east of the lowland; the Basin and Range province is wholly west of the lowland.

\section{MIDDLE ROCKY MOUNTAINS PROVINCE}

\section{SOUTHERN WASATCH RANGE}

The north-trending Wasatch Range, one of the great mountain masses of Utah, extends for about $240 \mathrm{~km}(150 \mathrm{mi})$ from near the Idaho border into central Utah. The south half of the range is formed by the upper plate of a thrust fault that I refer to as the Charleston-Nebo thrust fault. Other geologists, notably Bruce Bryant (U.S. Geological Survey, written commun., 1989), have objected to this coupling of what they perceive to be two separate thrust faultsthe Charleston and the Nebo thrust faults. Bryant believes that my Charleston-Nebo upper plate is divisible into two parts-a lower segment that is the upper plate of the Charleston thrust fault, and an upper segment that is the upper plate of the Nebo thrust fault. In Bryant's view, then, the Nebo thrust fault is an upper split off the Charleston thrust fault, and the Nebo fault dies out in the area northeast of Nephi (fig. 2, B-3) and southwest of Thistle (A-5).

I disagree with Bryant's interpretation. The stratigraphic units that I have mapped as part of the upper plate of the Charleston-Nebo thrust fault can be traced northeastward to Thistle where they join similar units that are part of the upper plate of the Charleston thrust fault. Neither the Nebo nor the 
Charleston thrust fault is exposed in the sector between Nephi and Thistle. Consequently, I am uncertain not only as to how many thrust faults underlie the area, but also as to where the fault(s) end (fig. 4). I believe that the Nebo thrust fault trends northeastward and eventually merges with the Charleston thrust fault; hence my use of the terms "Charleston-Nebo thrust fault" and "upper plate of the Charleston-Nebo thrust fault."

This upper plate of the Charleston-Nebo thrust fault, which reaches from near Salt Lake City southward to Nephi (B-3) (fig. 2, inset map), consists of a mass of basin-type rocks, at least $9,150 \mathrm{~m}(30,000 \mathrm{ft})$ thick (Crittenden, 1961) that was transported southeastward and eastward along the Charleston-Nebo thrust fault. How far the plate moved is unknown; various lines of evidence suggest a displacement of about $65 \mathrm{~km}$ (40 mi) (Crittenden, 1961, p. D-129).

Very generally, this upper plate can be divided into two segments: A northern part, east of Provo, that extends as far south as Spanish Fork Canyon; and a southern part, a wedge-shaped, imposing mountain range known locally as the southern Wasatch Mountains (or the southern Wasatch Range), that extends southward from Spanish Fork Canyon to Nephi (B-3). The extent of the plate south and west of Nephi is less certain, owing to basin and range structures. Part of the plate may be preserved west of Juab Valley (C-2), near the south end of Dog Valley (C-2), along the northwest flank of the West Hills (C-2). An erosional outlier near Levan (C-3) may be still another part of the plate (Witkind, 1983 , p. 49). Morris (1983, p. 77) has suggested, however, that near Nephi the causative, underlying Charleston-Nebo thrust fault may merge with the Leamington transcurrent fault.

The southern Wasatch Mountains now appear as the huge, intensely dissected east limb of an overturned, almost recumbent anticline. At the north end of the mountains, near Santaquin (A-3), the beds are right side up and dip moderately southeastward. Farther south the beds steepen, and near Mona (B-3), they are vertical. Still farther south, at the south end of the mountains, near Nephi, the beds are overturned and dip moderately to the northwest. The Wasatch fault zone truncates the west edge of the mountains, which thus appears as a straight, commanding escarpment overlooking Juab Valley. The east margin of the mountains-which I view as an erosional escarpment cut across the Charleston-Nebo thrust plate-is much less imposing, chiefly because it has been extensively eroded and then partly buried beneath younger Mesozoic and Tertiary rocks (Witkind, 1987). This erosional escarpment, which extends northeastward from Nephi toward Thistle
(A-5), may be the distal margin of the thrust plate (fig. $4 B$ ), or the distal margin may be concealed somewhere to the east beneath younger Mesozoic and Tertiary strata (fig. $4 C$ ). Near Thistle, the attitude of the beds that form the thrust plate in the subsurface is conjectural; they may be overturned.

\section{COLORADO PLATEAUS PROVINCE}

The terrain south and east of the southern Wasatch Mountains, and east of the lowland formed by the collinear alignment of Utah, Juab, and Sevier Valleys, is within the Colorado Plateaus province. I arbitrarily divide the area into two parts: the huge mass of the Wasatch Plateau, and the remainder to which I apply the well-established name SanpeteSevier Valley area.

\section{WASATCH PLATEAU}

The Wasatch Plateau, the northernmost of the High Plateaus of Utah, is a flat-topped mass about $130 \mathrm{~km}(80 \mathrm{mi})$ long that extends from Salina Creek Canyon (fig. 2, $\mathrm{H}-3$ ) on the south to the valleys of Soldier Creek (A-6) and Price River (B-8) on the north. The plateau trends about N. $20^{\circ}$ E., maintaining a nearly constant width of about $40 \mathrm{~km}(25 \mathrm{mi})$, and an altitude of about $3,050 \mathrm{~m}(10,000 \mathrm{ft})$. It separates Sanpete Valley (E-4) on the west from Castle Valley $(\mathrm{E}-7)$ on the east.

The plateau is underlain by flat-lying Cretaceous and Tertiary beds, most of which are well exposed in the dissected cliffs that delineate its eastern flank. These strata flex down sharply along much of the western flank of the plateau to form the Wasatch monocline (E-5). The monocline, about $100 \mathrm{~km}(62 \mathrm{mi})$ long, extends northward from Salina Creek Canyon (H-3) to its end, north of Milburn (B-5) and east of Indianola (B-5), near the north end of the east fork of Sanpete Valley. Westward-flowing consequent streams on the monocline have locally cut through the tilted beds, exposing them along the walls of deep, serpentine canyons that extend far back toward the crest of the plateau. Much of the plateau and the monocline are broken by high-angle normal faults that trend between due north and about N. $20^{\circ} \mathrm{E}$. and that locally are paired to form grabens.

\section{SANPETE-SEVIER VALLEY AREA}

The term "Sanpete-Sevier Valley area" refers to an ill-defined area drained by both the southflowing San Pitch River and the lower reaches of the north-flowing Sevier River. Over the years the 

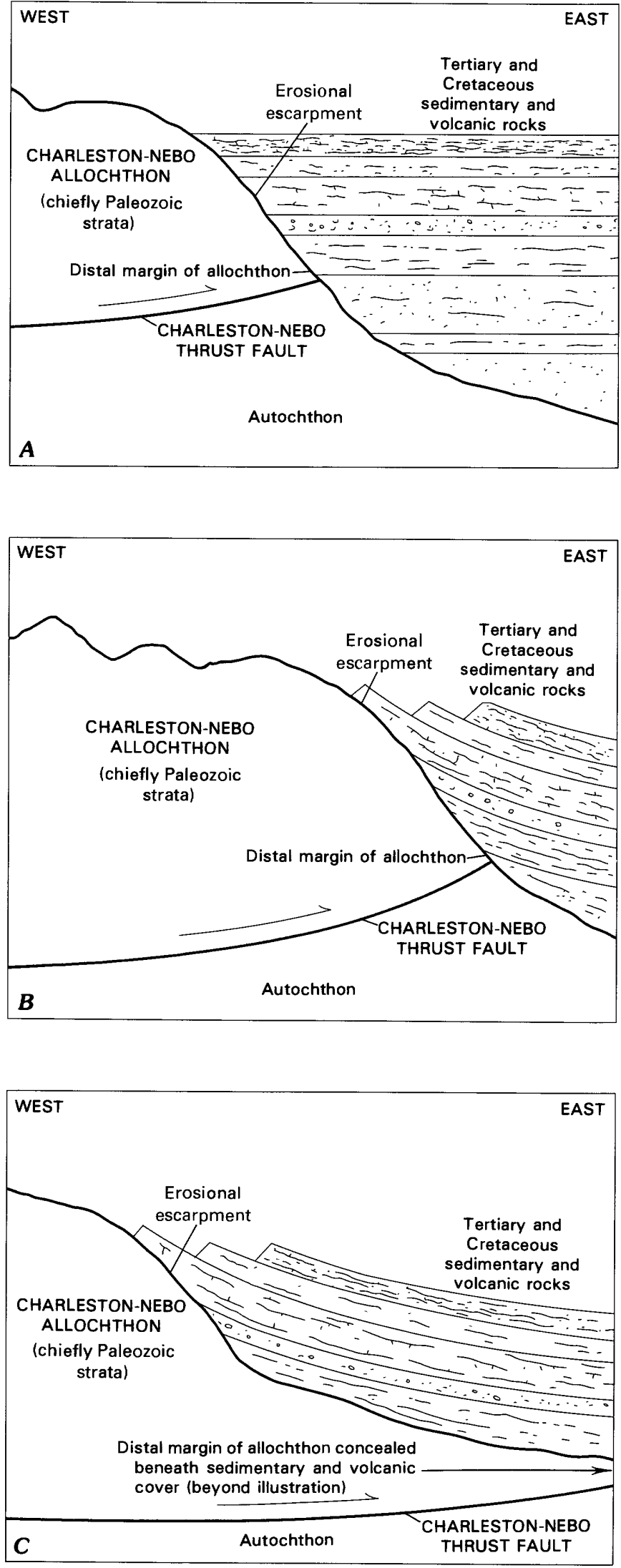

FIGURE 4.-Diagrammatic cross sections illustrating possible relations between an eastward-facing erosional escarpment formed on the Charleston-Nebo thrust plate and a partial cover of Cretaceous and Tertiary rocks. Escarpment was formed as the plate was thrust eastward. $A$, After eroded plate ground to a halt, sedimentary units of Cretaceous and Tertiary age, as well as some Tertiary volcanic units, were deposited against it, and in time may even have buried the entire plate. $B$, Erosional escarpment is at the distal margin of eroded thrust plate. $C$, Erosional escarpment is along east flank of eroded thrust plate but not at distal margin, which is farther to the east concealed beneath the Cretaceous and Tertiary cover. $B$ and $C$ represent two possible alternatives to explain present geologic relations. Both alternatives are viable; lack of data precludes a definitive statement as to position of the thrust plate's distal margin.

name San Pitch-derived from the name Sam Pete, a local Indian-has been garbled to Sanpete (M.P. Weiss, Northern Illinois University, oral commun., 1989), and this latter name is applied to the valley occupied by the San Pitch River. The SanpeteSevier Valley area has figured prominently in the geologic literature describing central Utah, and although certain localities in central Utah discussed in this report extend beyond the generally accepted limits of the Sanpete-Sevier Valley area, the name is so well known that I have used the name for the larger area.

In general, the Sanpete-Sevier Valley area appears as a series of north-trending plateaus and low hills, considerably lower than the adjacent Wasatch Range. Among the major landmasses in the Sanpete-Sevier Valley area are the Gunnison Plateau (D-3) (also known as the San Pitch Mountains), ${ }^{1}$ the Cedar Hills (B-4), and the Valley Mountains (G-2).

Jurassic, Cretaceous, and Tertiary sedimentary strata underlie the Sanpete-Sevier Valley area. Locally, these units are overlain by layered volcanic rocks and volcaniclastic detritus of Tertiary age. Commonly, both the sedimentary strata and the volcanic units are gently warped, to form broad folds that are broken, in places, by small high-angle normal faults. Here and there, however, these strata are complexly deformed into narrow elongate belts that trend northward.

"The range of hills known to geologists as the "Gunnison Plateau" is known to governmental agencies as the "San Pitch Mountains." Indeed, the latter name is used on published topographic maps of the U.S. Geological Survey. Nevertheless, the name Gunnison Plateau is so deeply entrenched in the geologic literature, chiefly as a result of the reports of the late Prof. E.M. Spieker and his many Ohio State University graduate students, that the name is retained and used throughout this report to avoid confusion. 


\section{BASIN AND RANGE PROVINCE}

\section{GREAT BASIN SECTION}

The Great Basin section is an arid lowland that ends abruptly eastward against the north-trending lowland formed by the collinear alignment of Utah, Juab, and Sevier Valleys. The abrupt change is emphasized by the impressive topographic high formed by the combined masses of the southern Wasatch Range (A-3) and the Gunnison Plateau (D-3) along the east side of the lowland. This abrupt topographic change is directly attributable to movement along the Wasatch fault zone, a major high-angle normal fault zone that trends northward across this part of central Utah, and along which the crustal block west of the fault zone has been downthrown relative to the block east of the fault zone.

The Great Basin sector consists of a series of thrust slices, composed chiefly of Precambrian and Paleozoic rocks. These thrust slices were deeply eroded during transport and after being emplaced, then buried beneath younger rocks, and broken by block faulting. Much of our knowledge of the Great Basin sector within this part of central Utah comes from two major mountain ranges that dominate the area: the Canyon Mountains (E-1), on the north, which have been described by Campbell (1979), Christiansen (1952), and Stolle (1978); and the Pavant Range (H-1) on the south, which has been described in part by Crosby (1959), and Lautenschlager (1952). As this discussion of diapirism in central Utah is confined chiefly to areas east of these ranges, no summary description is given here of the units that form them.

\section{DISTURBED ZONE}

Previous workers have suggested that the SanpeteSevier Valley area is best visualized as a transition zone between the Basin and Range province on the west and the Colorado Plateaus province on the east (Spieker, 1949). I suggest instead that although a zone does separate the two provinces, that zone is not a true transition zone in which features of one province gradually give way laterally to features of the adjacent province. Rather, I see the area between the two provinces as a disturbed zone marked by unusual, almost unique structural features that, for the most part, are foreign to both provinces. So, for example, the zone is unusual in that, in places, it is marked by both localized depositional thinning and complex structural deformation. Elongate, northwardtrending upwarps-huge upthrown masses of sedimentary rock-dominate the zone, yet comparable downwarps of the sedimentary units are nowhere to be found. In places, the beds are overturned, stand on end, or are downdropped to form long, linear grabens. Angular unconformities, otherwise sparse throughout this part of central Utah, are common and widespread. Locally, single outcrops contain several angular unconformities (figs. 19 and 32). The sedimentary beds thin drastically and anomalously, and locally pinch out near the crestal parts of these upwarps, but assume their regional thicknesses just short distances away. Those sedimentary units that do extend across the crestal parts of the upwarps are the uppermost, youngest parts of the formations. The contrast between the attitudes of the beds exposed in this zone and those flanking it is striking, and made even more so by the fact that this intense structural complexity is localized. In places, the overturned beds, traced laterally, resume their near-horizontal attitudes in distances as short as a kilometer (half a mile). Units that are in angular discordance can be traced laterally and within several kilometers become conformable. The rocks in the zone have been much disturbed, hence my preference for the term Disturbed Zone, rather than the more commonly accepted Transition Zone.

In my opinion, the trend and position of this disturbed zone reflect a fundamental flaw in the underlying basement rocks. This view is supported by the fact that three major structural elements have influenced this part of central Utah during time periods that span most of geologic time:

1. During the Paleozoic, the hingeline between the Cordilleran geosyncline on the west and the craton on the east trended northward through this area.

2. During the Jurassic, essentially the same geographic area was occupied by a major, structurally determined saline basin, termed the Arapien basin by Stokes (1982).

3. During the Tertiary and Quaternary, the structural seam between the Basin and Range and the Colorado Plateaus provinces extended northward through the area.

The disturbed zone overlies much of Stokes' Arapien basin. The greatest thickness of salt appears to have been deposited in this saline basin (D.A. Sprinkel, Placid Oil Co., oral commun., 1983), implying strongly that the anomalous sedimentary thinning and the complex structures so characteristic of the disturbed zone stem, in one way or another, from 
movement of these thick salt deposits. As Halbouty noted (1967, p. 5): "The major salt basins of the world * * *are not simple, arbitrarily positioned evaporite pans* * *but rather* * *reflect major negative elements which are probably related to re-activation of basement structures."

\section{DEFINITIONS}

I use four terms throughout this Professional Paper, and it seems wise to explain my usage of them and how they differ from similar or comparable terms used in and near the Gulf Coast.

Salt diapir. As used along the Gulf Coast, "salt diapir" commonly refers to a body of almost pure rock salt, generally round or crudely elliptical and with nearly vertical sides, whose shape has determined the configuration of a salt-cored dome. By contrast, in this part of central Utah, I believe that the salt diapirs are elongate, narrow, somewhat sinuous bodies of salt and intercalated mudstone that extend for tens of kilometers. They appear to be comparable to the linear "salt cores" of the Paradox Basin, Colorado and Utah (Shoemaker and others, 1958, p. 39), or the "salt walls," described by Trusheim (1960, fig. 4), that formed in the Zechstein salt of northern Germany. Rather than almost pure rock salt, the salt diapirs in central Utah consist of thick beds and stringers of salt and anhydrite interlayered with calcareous mudstone and shaly siltstone. I visualize these salt diapirs, like those along the Gulf Coast, as piercement structures which, in their upward rise, intruded, arched, and deformed the overlying sedimentary rocks (fig. 5). The salt diapirs in central Utah probably stem from one or more source beds of salt.

Diapiric sheath. I believe that each salt diapir in central Utah is sheathed by calcareous mudstone and shaly siltstone beds that deformed plastically with the rising salt. These rocks are part of the Arapien Shale; pushed up by the driving salt they have intruded and deformed the overlying sedimentary rocks. I interpret them as intrusive sedimentary beds. In most places, I suspect that these calcareous mudstone beds are in intrusive contact with those consolidated and semiconsolidated rocks that overlie them. Although a similar sheath, but of shale, was called a "diapiric shale" by Atwater and Forman (1959), I believe the term "sheath" better describes the relations between the enveloping mudstone beds and the salt diapir.

Diapiric fold. The younger sedimentary rocks deformed by the diapiric sheaths are generally flexed up to form elongate, faintly sinuous, narrow upwarps, whose trend and extent reflect the underlying causative salt diapir. These upwarps, most of which probably were originally fan-shaped in cross section, can be traced for long distances through central Utah. Other workers (Spieker, 1949; Gilliland, 1963; Willis, 1986) have referred to these linear upwarps as "anticlines," but I prefer the term "diapiric folds," to emphasize the critical concept that only the salt-bearing and younger beds have been intensely deformed by the rising salt. The pre-salt units may be greatly deformed, but that deformation probably stems from orogenic forces, and not from the rising salt (p. 16). In this sense, then, I view the stack of sedimentary units in central Utah as consisting of two parts: the salt-bearing and overlying younger rocks, and an older pre-salt sequence. The complex structures I describe stem from repeated movement of the salt-bearing and younger rocks. Another acceptable term to describe these upwarps is "salt-cored anticline"; I arbitrarily chose "diapiric fold" because it clearly conveys the diapiric concept and also contains fewer letters.

Salt is the motive force ultimately responsible for development of the diapiric folds. Subsequent withdrawal of the salt, by dissolution or extrusion, resulted in failure of the folds. Prior to erosion, these diapiric folds must have resembled the "salt anticlines" (salt-cored anticlines) of the Paradox Basin.

Diapiric core. The core of a diapiric fold consists of both the innermost salt diapir and its surrounding diapiric sheath. In most localities in central Utah, it is mainly the diapiric sheath of Arapien Shale mudstone beds that is exposed.

\section{STRATIGRAPHY}

\section{GENERAL STRATIGRAPHY}

The sedimentary rocks that crop out in this part of central Utah consist of two sequences: one sequence comprises the autochthonous plate that underlies much of the Sanpete-Sevier Valley area (table 1); the second forms much of the Charleston-Nebo thrust plate, which extends northeastward from the Mount Nebo area to Thistle and beyond (table 2). No attempt is made to describe either of these sequences in detail. The rocks of the Sanpete-Sevier Valley area have been described repeatedly and thoroughly by Spieker and his many graduate students (Spieker, 1946, 1949; Gilliland, 1948, 1951; Hardy, 1952; Schoff, 1951; Hardy and Zeller, 1953; and McGookey, 1960, among others). Those underlying the area are from Cambrian to Holocene in age; most of the indurated units that 


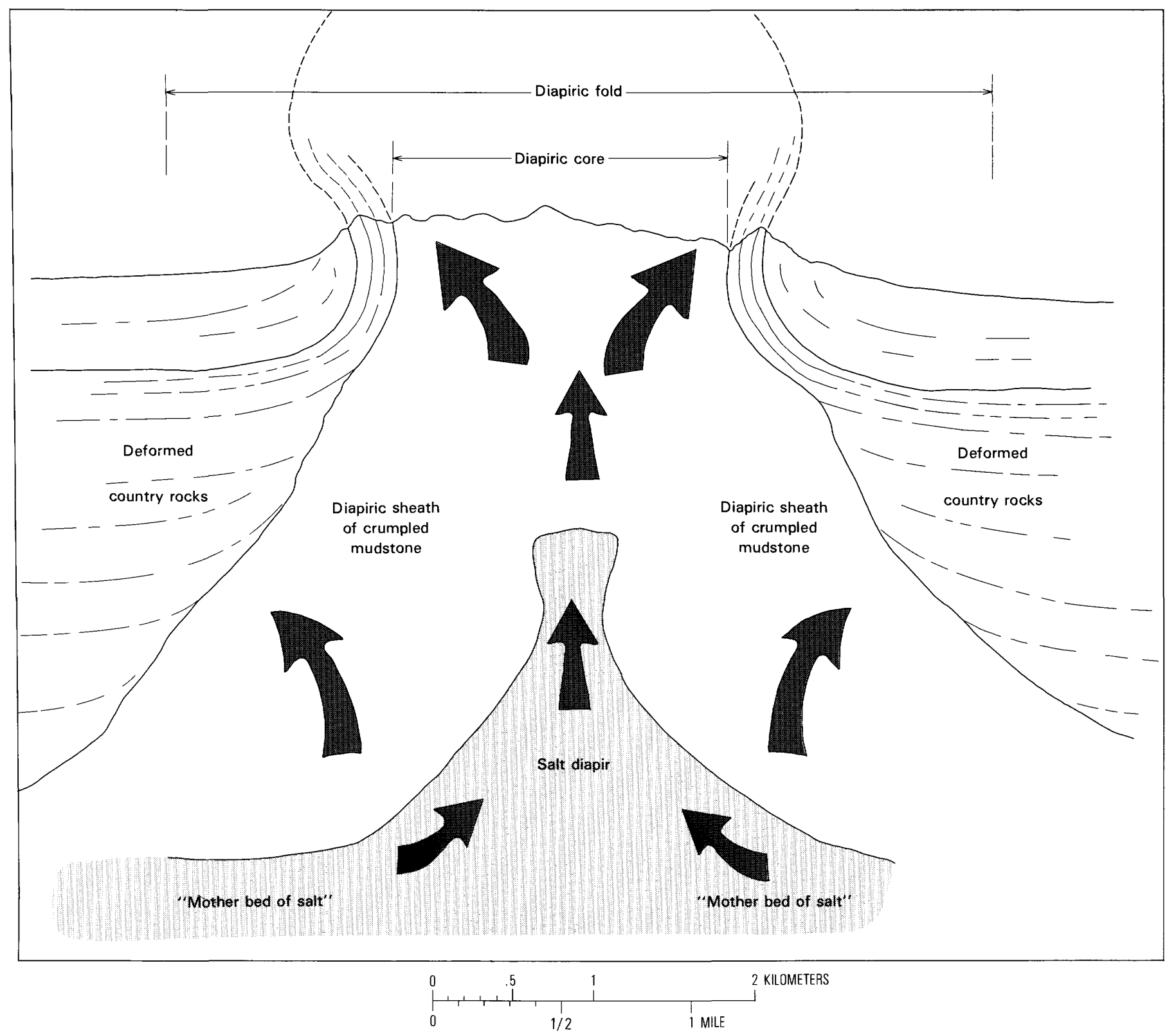

FIGURE 5.-Possible geologic relations between a salt diapir, the diapiric sheath of mudstones of the Arapien Shale, and the upturned country rock that together form the diapiric fold. The salt diapir and its diapiric sheath compose the diapiric core of the fold. Arrows denote general direction of movement of plastic and mobile salt and mudstone. In places, vertical forces, stemming from the intrusive salt diapir, are translated laterally into horizontal compressive forces. Scale is approximate.

figure prominently in my report are of Mesozoic and Cenozoic age. The rocks of the thrust plate have been described by Eardley (1933a, 1933b), Muessig (1951), Johnson (1959), Hintze (1962), Bissell (1962), Rigby and Clark (1962), Black (1965), and most recently by LeVot (1984), Banks (1986, 1988), and Biek (1988a, b). Exposed units range in age from Pennsylvanian to Jurassic. Tables 1 and 2 summarize the salient details of the stratigraphic section.
As noted previously, I attribute much of the structural deformation in central Utah to multiple episodes of salt diapirism. The rock salt (halite) and other evaporites that I believe are ultimately responsible for this structural complexity in central Utah are contained within the Arapien Shale-one of the most unusual stratigraphic units in central Utah. Consequently, in the following pages, I discuss that unit in considerable detail. 
TABLE 1.-Some stratigraphic units exposed in the Sanpete-Sevier Valley area, central Utah

[Query, age, boundary, or thickness uncertain]

\begin{tabular}{|c|c|c|c|c|c|c|}
\hline \multirow[t]{2}{*}{ SYSTEM } & \multirow[t]{2}{*}{ SERIES } & \multirow{2}{*}{\multicolumn{2}{|c|}{ UNIT }} & \multicolumn{2}{|c|}{$\begin{array}{l}\text { APPROXIMATE } \\
\text { THICKNESS }\end{array}$} & \multirow[t]{2}{*}{ LITHOLOGY } \\
\hline & & & & METERS & FEET & \\
\hline \multirow{10}{*}{ Tertiary } & Pliocene(?) & \multicolumn{2}{|c|}{$\begin{array}{l}\text { Axtell Formation } \\
\text { of Spieker (1949) }\end{array}$} & $15-23$ & $50-75$ & $\begin{array}{l}\text { light gray to gray; thin bedded to massive; semiconsolidated; } \\
\text { forms broad gravel-capped benches that flank modern major } \\
\text { stream valleys. }\end{array}$ \\
\hline & Miocene & \multicolumn{2}{|c|}{ Osiris Tuff } & 152 & 500 & $\begin{array}{l}\text { Tuff, light-gray to dark-gray to black, thick- bedded to massive, } \\
\text { fine-grained, porphyritic; disintegrates into angular blocks and } \\
\text { fragments that form extensive debris fields. }\end{array}$ \\
\hline & \multirow{2}{*}{ Oligocene } & \multicolumn{2}{|c|}{$\begin{array}{l}\text { Gray Gulch Formation } \\
\text { of Spieker (1949) }\end{array}$} & $\begin{array}{c}0- \\
213\end{array}$ & $\begin{array}{c}0- \\
700\end{array}$ & $\begin{array}{l}\text { Volcanic ash beds, with interbedded sandstone, shale, and } \\
\text { limestone; mostly light gray, thin bedded to massive; friable; } \\
\text { weathers to moderate slopes. }\end{array}$ \\
\hline & & $\begin{array}{l}\text { Bald Knoll For } \\
\text { of Gilliland ( } 1\end{array}$ & $\begin{array}{l}\text { mation } \\
951)^{1}\end{array}$ & $305 ?$ & $1,000 ?$ & $\begin{array}{l}\text { Mudstone, siltstone, and sandstone, light-gray to tan, } \\
\text { thin-bedded; few thin intercalated light-gray, aphanic limestone } \\
\text { beds. }\end{array}$ \\
\hline & \multirow{4}{*}{ Eocene } & \multicolumn{2}{|c|}{$\begin{array}{l}\text { Crazy Hollow Formation } \\
\text { of Spieker (1949) }\end{array}$} & $\begin{array}{c}0- \\
305\end{array}$ & $\begin{array}{c}0- \\
1,000\end{array}$ & $\begin{array}{l}\text { Sandstone, shaly siltstone, and some conglomerate; light gray } \\
\text { to reddish brown; thin to medium bedded, locally crossbedded. } \\
\text { Light-gray salt-and-pepper sandstone containing distinctive } \\
\text { black, well-rounded chert pebbles at base. }\end{array}$ \\
\hline & & \multicolumn{2}{|c|}{ Green River Formation } & 365 & 1,200 & $\begin{array}{l}\text { Consists of a limestone unit underlain by a shale unit. Limestone } \\
\text { unit. - Yellowish gray to yellow brown to light brown; thin to thick } \\
\text { bedded; even bedded. Contains thin sandstone and tuff beds. } \\
\text { Limestone beds are dense and commonly oolitic. Forms resistant } \\
\text { ledges and low cliffs. Shale unit. - Light green to grayish green; } \\
\text { fissile; thin bedded; a few interleaved limestone beds. Forms } \\
\text { gentle slopes. }\end{array}$ \\
\hline & & \multicolumn{2}{|c|}{ Colton Formation } & $\begin{array}{l}137- \\
487\end{array}$ & $\begin{array}{l}450- \\
1,600\end{array}$ & $\begin{array}{l}\text { Claystone and mudstone, variegated in shades of red and gray; } \\
\text { few thin interbeds of light-brown to reddish-brown siltstone, } \\
\text { fine-grained sandstone, and conglomerate; sparse thin beds of } \\
\text { light-gray aphanic limestone; irregularly bedded. Locally, basal } \\
\text { units are coarsely conglomeratic. }\end{array}$ \\
\hline & & \multirow{2}{*}{\multicolumn{2}{|c|}{ Flagstaff Limestone }} & $16-$ & $50-$ & $\begin{array}{l}\text { Limestone and dolomitic limestone, light-gray to yellowish-gray } \\
\text { to light-brown; locally pale red; thin to thick bedded, locally }\end{array}$ \\
\hline & \multirow{2}{*}{ Paleocene } & & & 548 & 1,800 & $\begin{array}{l}\text { massive; even bedded, aphanic. Contains subordinate inter- } \\
\text { bedded dark-gray, gray, and greenish-gray shale. }\end{array}$ \\
\hline & & \multirow{2}{*}{\multicolumn{2}{|c|}{ North Horn Formation }} & $45-$ & $150-$ & $\begin{array}{l}\text { Mudstone, sandstone, conglomeratic sandstone, and sparse } \\
\text { limestone; units alternate irregularly. Light yellow, buff, and light }\end{array}$ \\
\hline \multirow{6}{*}{ Cretaceous } & \multirow{6}{*}{$\begin{array}{c}\text { Upper } \\
\text { Cretaceous }\end{array}$} & & & 915 & 3,000 & $\begin{array}{l}\text { brown, locally reddish brown; thin to thick bedded. Unstable, } \\
\text { marked by many mass-wasting deposits. }\end{array}$ \\
\hline & & \multicolumn{2}{|c|}{ Price River Formation } & $\begin{array}{c}6- \\
609\end{array}$ & 2,000 & $\begin{array}{l}\text { Conglomerate, conglomeratic sandstone, sandstone, and sparse } \\
\text { shaly siltstone; light gray to gray; thin to thick bedded, locally } \\
\text { crossbedded. Forms steep slopes and low cliffs. }\end{array}$ \\
\hline & & \multirow{4}{*}{$\begin{array}{l}\text { Indianola Group, un- } \\
\text { divided }(915-2,130 \mathrm{~m} \\
(3,000-7,000 \mathrm{ft})) \text { : Con- } \\
\text { glomerate, red to } \\
\text { reddish brown, thick- } \\
\text { bedded to massive, } \\
\text { well-cemented; con- } \\
\text { sists of well-rounded } \\
\text { pebbles, cobbles, and } \\
\text { boulders of quartizite, } \\
\text { quartz, chert, and } \\
\text { limestone; few inter- } \\
\text { leaved reddish-brown } \\
\text { sandstone beds. }\end{array}$} & $\begin{array}{l}\text { East of } \\
\text { Sanpete Valley: } \\
\text { Sixmile Canyon } \\
\text { Formation }\end{array}$ & 830 & 2,725 & $\begin{array}{l}\text { Sandstone, conglomeratic sandstone, carbonaceous shale, and } \\
\text { some coal; brown to brownish gray, locally light tan to light gray; } \\
\text { thin to medium bedded; conglomeratic in basal part. }\end{array}$ \\
\hline & & & $\begin{array}{l}\text { Funk Valley } \\
\text { Formation }\end{array}$ & 685 & 2,250 & $\begin{array}{l}\text { Sandstone and interbedded shale; sandstone is light brown to } \\
\text { yellow brown, thin to medium bedded, fine to medium grained; } \\
\text { shate is gray, even bedded, and fissile. }\end{array}$ \\
\hline & & & $\begin{array}{l}\text { Allen Valley } \\
\text { Shale }\end{array}$ & $\begin{array}{l}182- \\
245\end{array}$ & $\begin{array}{l}600- \\
800\end{array}$ & $\begin{array}{l}\text { Shale, dark-gray to black, thin- and even bedded; contains thin } \\
\text { beds of "siltstone, of very fine-grained sandstone, and gray } \\
\text { limestone" (Spieker, 1946, p. 128). }\end{array}$ \\
\hline & & & $\begin{array}{l}\text { Sanpete } \\
\text { Formation }\end{array}$ & 410 & 1,350 & $\begin{array}{l}\text { Sandstone and conglomeratic sandstone, brown to } \\
\text { brownish-gray; thin-to medium bedded: sandstones are fine to } \\
\text { medium grained; basal part of formation is conglomeratic. }\end{array}$ \\
\hline
\end{tabular}


TABLE 1.-Some stratigraphic units exposed in the Sanpete-Sevier Valley area, central Utah-Continued

\begin{tabular}{|c|c|c|c|c|c|}
\hline \multirow[t]{2}{*}{ SYSTEM } & \multirow[t]{2}{*}{ SERIES } & \multirow{2}{*}{ UNIT } & \multicolumn{2}{|c|}{$\begin{array}{l}\text { APPROXIMATE } \\
\text { THICKNESS }\end{array}$} & \multirow[t]{2}{*}{ LITHOLOGY } \\
\hline & & & METERS & FEET & \\
\hline Cretaceous & $\begin{array}{l}\text { Lower } \\
\text { Cretaceous }\end{array}$ & Cedar Mountain Formation & $\begin{array}{l}90- \\
610\end{array}$ & $\begin{array}{l}300- \\
2,000\end{array}$ & $\begin{array}{l}\text { Shaly siltstone and mudstone; reddish brown to light gray, but } \\
\text { locally variegated in shades of pink and violet; contains white } \\
\text { limestone bed. Contains abundant light-gray, small, rounded } \\
\text { limestone nodules. Unstable, marked by many earthflows and } \\
\text { landsides. }\end{array}$ \\
\hline \multirow{4}{*}{ Jurassic } & \multirow{3}{*}{$\begin{array}{l}\text { Middle } \\
\text { Jurassic }\end{array}$} & Twist Gulch Formation & 915 & 3,000 & $\begin{array}{l}\text { Shaly siltstone and sandstone, reddish-brown, thin- and even } \\
\text { bedded; contains many very thin interbeds of light-gray, } \\
\text { fine-grained sandstone and siltstone. }\end{array}$ \\
\hline & & Arapien Shale & $\begin{array}{l}1,220- \\
3,960\end{array}$ & $\begin{array}{l}4,000- \\
13,000\end{array}$ & $\begin{array}{l}\text { Calcareous mudstone, shaly siltstone, shale, sparse limestone, } \\
\text { with much salt and other evaporites. Variegated; commonly } \\
\text { mottled red and gray. }\end{array}$ \\
\hline & & $\begin{array}{l}\text { Members of the } \\
\text { Twin Creek Limestone }\end{array}$ & $\begin{array}{c}100- \\
137\end{array}$ & $\begin{array}{l}320- \\
450\end{array}$ & $\begin{array}{l}\text { Dominantly limestone, light- to dark-gray, thin to massive, } \\
\text { even-bedded, dense, argillaceous. In places, intensely folded and } \\
\text { fractured. Includes the following seven members in descending } \\
\text { order: Giraffe Creek, Leeds Creek, Watton Canyon, Boundary } \\
\text { Ridge, Rich, Sliderock, and Gypsum Spring. All members except } \\
\text { the Giraffe Creek are exposed in central Utah. }\end{array}$ \\
\hline & $\begin{array}{l}\text { Lower } \\
\text { Jurassic }\end{array}$ & $\begin{array}{l}\text { Navajo Sandstone } \\
\text { (Nugget Sandstone) }\end{array}$ & $\begin{array}{l}150- \\
305\end{array}$ & $\begin{array}{l}500- \\
1,000\end{array}$ & $\begin{array}{l}\text { Sandstone, light-brown to buff, locally reddish orange, medium- } \\
\text { to thick-bedded, massive, fine-to medium-grained, quartzose. }\end{array}$ \\
\hline
\end{tabular}

${ }^{1}$ Recent work by Willis (1986) has suggested that the Bald Knoll strata exposed in the type section are not correlative with other rocks mapped as Bald Knoll elsewhere in central Sevier Valley. Pending resolution of this problem, Willis $(1986, p$. 6) used the term "The formation of Aurora" for the units here designated as the Bald Knoll Formation of Gilliland (1951).

TABLE 2.-Some stratigraphic units exposed in the Charleston-Nebo thrust plate, Mount Nebo area, central Utah

[Query, boundary or thickness uncertain]

\begin{tabular}{|c|c|c|c|c|c|}
\hline \multirow[t]{2}{*}{ SYSTEM } & \multirow[t]{2}{*}{ SERIES } & \multirow[t]{2}{*}{ UNIT } & \multicolumn{2}{|c|}{$\begin{array}{l}\text { APPROXIMATE } \\
\text { THICKNESS }\end{array}$} & \multirow[t]{2}{*}{ LITHOLOGY } \\
\hline & & & METERS & FEET & \\
\hline \multirow{2}{*}{ Jurassic } & $\begin{array}{l}\text { Middle } \\
\text { Jurassic }\end{array}$ & Twin Creek Limestone & $?$ & $?$ & $\begin{array}{l}\text { Chiefly light gray, thin-bedded limestone; includes interbedded } \\
\text { reddish-brown shaly siltstone members. }\end{array}$ \\
\hline & $\begin{array}{l}\text { Lower } \\
\text { Jurassic }\end{array}$ & Navajo Sandstone & 180 & $600 ?$ & $\begin{array}{l}\text { Orange-brown to reddish-brown to light-brown, thick-bedded, fine- to } \\
\text { medium-grained quartzose sandstone. }\end{array}$ \\
\hline \multirow{3}{*}{ Triassic } & $\begin{array}{l}\text { Upper to } \\
\text { Lower } \\
\text { Triassic }\end{array}$ & Ankareh Formation & 122 & 400 & $\begin{array}{l}\text { Reddish-brown shaly siltstone and crossbedded sandstone with some } \\
\text { intercalated thin conglomerate beds. }\end{array}$ \\
\hline & \multirow{2}{*}{$\begin{array}{l}\text { Lower } \\
\text { Triassic }\end{array}$} & Thaynes Limestone & $\begin{array}{l}90- \\
305\end{array}$ & $\begin{array}{l}300- \\
1,000\end{array}$ & $\begin{array}{l}\text { Chiefly light gray limestone with some reddish-brown to light-gray shaly } \\
\text { siltstone and sandstone beds. }\end{array}$ \\
\hline & & Woodside Sandstone & 120 & 400 & $\begin{array}{l}\text { Reddish-brown shaly siltstone and crossbedded, fine- to medium-grained } \\
\text { sandstone. }\end{array}$ \\
\hline \multirow{3}{*}{ Permian } & \multirow{3}{*}{$\begin{array}{l}\text { Lower } \\
\text { Permian }\end{array}$} & Park City Formation & 200 & 650 & $\begin{array}{l}\text { Chiefly light gray to pale-red, thin- to thick-bedded limestone; includes beds } \\
\text { of brownish-black cherty limestone. }\end{array}$ \\
\hline & & Diamond Creek Sandstone & 120 & 400 & $\begin{array}{l}\text { Reddish-brown to light-brown crossbedded sandstone; some intercalated } \\
\text { limestone. }\end{array}$ \\
\hline & & Kirkman Limestone & 113 & 320 & Light- to medium-gray, thin- to thick-bedded limestone; contains chert. \\
\hline Pennsylvanian & $\begin{array}{c}\text { Upper to } \\
\text { Lower } \\
\text { Pennsylvanian }\end{array}$ & Oquirrh Group & 3,505 & 11,500 & $\begin{array}{l}\text { Gray to brownish-gray, thin- to thick-bedded limestone and interbedded } \\
\text { light-brown, fine- to medium-grained sandstone. }\end{array}$ \\
\hline
\end{tabular}

${ }^{1}$ Thicknesses from Eardley, 1933a; Johnson, 1959; and Black, 1965. 
The stratigraphic units that form the autochthonous plate are divisible into two parts-the saltbearing (Arapien Shale) and younger strata, which locally are intensely deformed, and the pre-salt units, which, although deformed, owe their deformation to orogenic forces and not to the repeated movement of the salt. This division of the sedimentary stack is important, not only in visualizing more clearly the structural relations, but also for economic reasons: suitable traps for the accumulation of oil and gas may be formed either along the flanks of the salt diapirs, or in those folded, older rocks that underlie the masking blanket of diapirically folded rocks. Unless one recognizes this structural discontinuity, one might never realize that two different types of structural traps are in the area.

\section{THE ARAPIEN SHALE}

\section{NOMENCLATURE}

The Arapien was originally defined by Spieker (1946, p. 123-125) who recognized five lithologic rock types. He described them as follows (1946, p. 124):

$* * *$ there are five different types of lithologic assemblage, in which the order of succession, beginning with the lowermost, is commonly but by no means regularly as follows: (1) Gray limestone, generally thin-bedded; (2) light-gray siltstone and shale, very thin-bedded, with occasional thin beds of finely rippled sandstone; (3) gray shale, argillaceous and gypsiferous, with irregular red blotches, which locally become dominant; (4) compact red saltbearing shale; (5) thin-bedded red siltstone and shale with many thin layers of greenish white siltstone and occasional zones of gray sandstone, some of which is fairly coarse grained.

Of the five units recognized, Spieker believed that the first four could not be traced over long distances. Type 5 , by contrast, appeared to Spieker to be sufficiently consistent in lithology and appearance to warrant its being a named member. Spieker, therefore, divided the five types into two members; he named type 5 the "Twist Gulch member," and grouped and named the underlying four units the "Twelvemile Canyon member."

In the late 1940's, Clyde T. Hardy, then one of Spieker's graduate students, began a study of the Twelvemile Canyon Member. Hardy soon became convinced that the Twist Gulch and Twelvemile Canyon Members were sufficiently distinct and widespread to warrant separate formational status. Spieker agreed, and consequently Hardy (1952, p. 14) noted: "The Arapien shale was defined by E.M. Spieker in 1946, as a formation with two distinct members (Spieker, 1946, pp. 123-125). The term is now restricted to the strata formerly included in the Twelvemile Canyon member, and the Twist Gulch member is redesignated as a formation because of its great areal extent in central Utah (Hardy and Spieker, in preparation)."

The Hardy-Spieker paper was never published, but most subsequent authors seemingly assumed that the paper was in print, or simply accepted the reasonableness of Hardy's proposal, and used the term "Arapien shale" in a formational sense much as proposed by Hardy, and as an exact replacement for the name "Twelvemile Canyon Member." Regrettably, Hardy's proposal infringed on the existing code of stratigraphic nomenclature, which forbade using the original name of a unit ("Arapien shale") for one of its divisions ("Twelvemile Canyon Member"). The result was dual usage of the name "Arapien shale." U.S. Geological Survey geologists used the name in its original sense, as a formation with an upper Twist Gulch Member and a lower Twelvemile Canyon Member. Industry and academic geologists used the name in its formational sense and as a direct replacement for the term "Twelvemile Canyon member." This dual usage caused much confusion. To resolve the problem, Hardy and I proposed (Witkind and Hardy, 1984) that the Twist Gulch Member be raised to formational rank, that the units now grouped as the Twelvemile Canyon Member be known as the Arapien Shale, and that the name Twelvemile Canyon Member be abandoned. Although this action also violates Article $19 \mathrm{~g}$ of the North American Stratigraphic Code (North American Commission on Stratigraphic Nomenclature, 1983), we believed that widespread and common usage argued persuasively for such a change. In this Professional Paper I follow this terminology and treat the Twist Gulch and the Arapien Shale as separate formations.

FIGURE 6 (facing page).-Aspects of the Twist Gulch Formation, and the Arapien Shale. A, Exposure of the Twist Gulch Formation at north end of a low hogback near an ancestral course of Willow Creek. Twist Gulch strata, downthrown along a near-vertical, normal fault, dip westward and abut vertical beds of the Flagstaff Limestone. Structural relations in this locality are discussed in the section, "Ancestral Willow Creek area." $B$, Arapien Shale exposure in the White Hills, Willow Creek area. Masses of pale-red mudstone scattered irregularly through light-gray mudstone give unit a distinctive mottled appearance. As mudstone beds are readily dissected, badland topography commonly characterizes Arapien exposures. $C$, View looking eastward across Sanpete Valley at a low, gray, unnamed, north-trending ridge (west of Ninemile Reservoir), composed of Arapien strata, chiefly overturned beds of limy mudstone, siltstone, and sandstone. Overturned beds of the Indianola Group (foreground) are part of the exposure that makes up the Red Rocks area. $D$, Exposure about 5 $\mathrm{km}$ (3 mi) east of Nephi, along north valley wall of Salt Creek, of light-gray, thin, vertical platy beds characteristic of some facies of the Arapien Shale. 

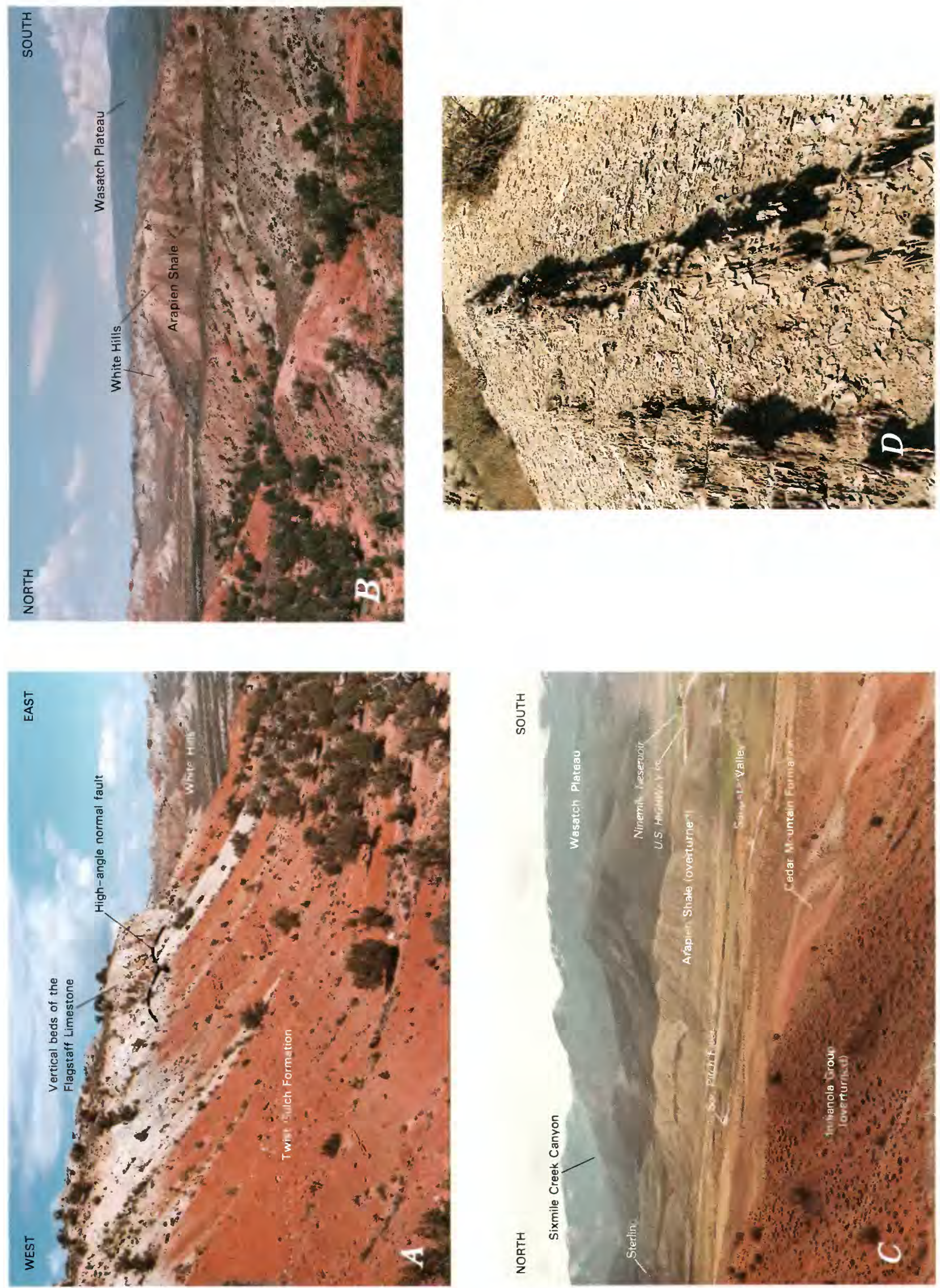


\section{TWIST GULCH FORMATION}

The Twist Gulch Formation consists of a series of reddish-brown to brown, thin- to medium-bedded shaly siltstone and fine- to medium-grained sandstone beds. Light-gray to gray, thin, fine- to mediumgrained sandstone beds and laminae are interleaved in the sequence. The unit weathers to moderate slopes broken by small steplike ridges formed by the more resistant sandstone beds (fig. 6A). The unit is distinctive and differs strikingly in details of weathering and lithology from the underlying Arapien Shale (fig. 6B). The thickness of the Twist Gulch Formation ranges from about $60 \mathrm{~m}(200 \mathrm{ft})$ to about $915 \mathrm{~m}$ (3,000 ft) (Spieker, 1946, p. 125).

Twist Gulch strata, in central Utah, seemingly grade into the overlying mudstones of the Cedar Mountain Formation of Early Cretaceous age. Much uncertainty surrounds both the age of the Twist Gulch and the units with which it is correlative. Imlay (1980, p. 74) assigned the Twist Gulch to the Middle Jurassic (Callovian). Its upper age limit is uncertain. It may extend into the Late Jurassic (Witkind, Standlee, and Maley, 1986), or Early Cretaceous (Villien, 1984, p. 40). Although Imlay (1980, p. 74) suggested that the Twist Gulch is essentially equivalent to the Entrada, I follow Hardy (1949, p. 36), and believe the Twist Gulch is probably correlative with the Middle Jurassic (Callovian) Entrada, Curtis, and Summerville Formations of the San Rafael Group.

\section{ARAPIEN SHALE (GEOLOGIC ASPECTS)}

\section{LITHOLOGY}

Hardy's (1949, 1952) exhaustive study of the Arapien Shale (then known as the Twelvemile Canyon Member) was an attempt to understand better the bewildering lateral and vertical changes in that unit. As a result of his work, he divided Spieker's original four rock types into five lithologic units. Hardy's description of these units (which exclude the Twist Gulch Formation) is listed, in ascending order, herein (Hardy, 1949, p. 15-16):

\section{Unit E:}

Brick-red silty shale locally salt-bearing. The salt appears to be stratified and commonly contains a considerable amount of red clay. At least 200 feet $[60 \mathrm{~m}]$ of salt is exposed east of Redmond, and north of Redmond in the Sevier Valley.

\section{Unit D:}

Alternate layers of bluish-gray and red gypsiferous shale. Blotched appearance of the outcrop due to lenticular nature of the beds, facies changes, and complex structures.
Unit C:

Bluish-gray calcareous shale with gray thin-bedded calcareous sandstone. Several prominent layers of arenaceous limestone with fossils. Massive lenticular beds of gypsum.

Unit B:

Bluish-gray and red gypsiferous shale. Blotched appearance as Unit D. Red gypsiferous shale in upper part locally salt-bearing.

\section{Unit A:}

Gray shale, gray thin-bedded limestone weathers brown, red shale, gypsum in thin lenticular beds; or gray thin-bedded argillaceous limestone with massive lenticular beds of gypsum.

Although these units appear as sequential stratigraphic units in the Salina area (Willis, 1986), in most places where I have examined the Arapien, the units appear to intermingle, and are perhaps best described as distinctive lithologic rock types. Seemingly, these units occur irregularly at various stratigraphic intervals, and, as a result, rapid lateral changes in lithology and color are characteristic.

In some localities, as in Salt Creek Canyon east of Nephi (B-3), the Arapien Shale changes radically in appearance from place to place. Commonly, the Arapien is a light-gray calcareous mudstone mottled here and there with pale-red blotches. This is its appearance in the White Hills (G-3) near Mayfield (F-3) (fig. 6B). In other places, it is uniformly drab gray, as in the Pigeon Creek-Chicken Creek (C-3) area along the west flank of the Gunnison Plateau (D-3); still elsewhere, it is uniformly reddish brown, as in the North Fork of Salt Creek (east of Nephi), or near Redmond (G-3).

In general, the Arapien consists of an alternating sequence of beds of calcareous mudstone (the "micrite" of Picard, 1980, p. 137), gypsiferous shale, siltstone, fine-grained sandstone, and sparse limestone. Most of these units are so soft that the formation tends to form badland topography marked by intricately dissected low hills and ridges separated by narrow, sinuous valleys. Thin to thick beds of evaporite, chiefly rock salt (halite), gypsum, anhydrite, and calcite are integral parts of the formation (fig. 7). Selenite crystals litter many outcrops. At one time salt was mined in Salt Creek, north of the KOA Campground (B-3), and near Sterling ( $\mathrm{F}-4)$. Currently, it is being mined near Redmond; large amounts of it underlie central Utah (Moulton, 1975), and large amounts have been dissolved and removed. Virtually all the diapiric features discussed in this report formed in response to movement of salt masses many of which have since been dissolved. The critical factor is not how much salt underlies central Utah at the present time, but rather how much salt underlay the area in the past when most of the diapiric structures were formed. 


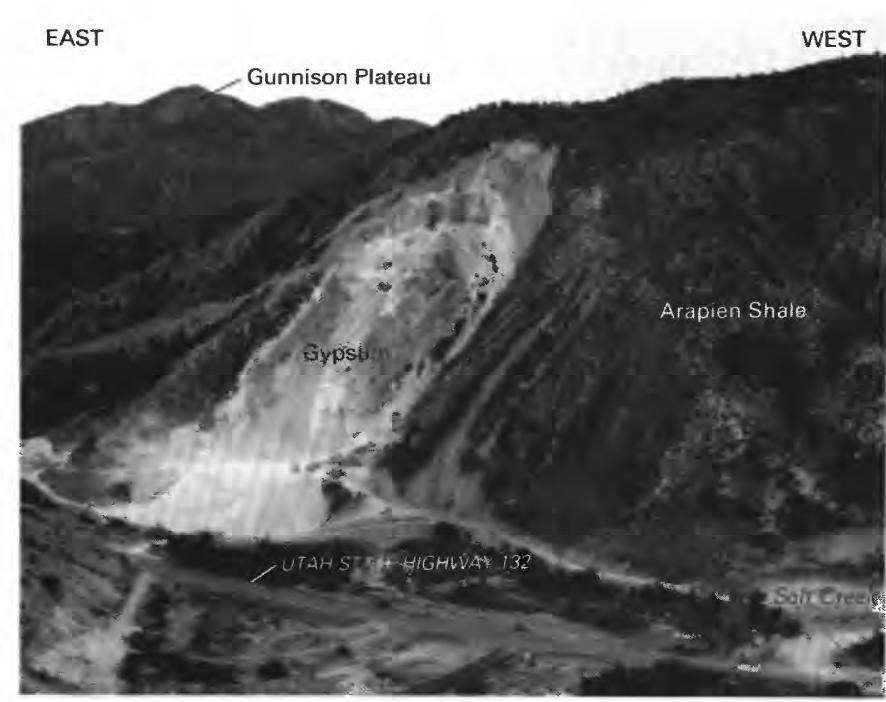

FiguRE 7.-Gypsum mass within the Arapien Shale. Mine is about $1.5 \mathrm{~km}(1 \mathrm{mi})$ east of Nephi.

In places, the Arapien Shale appears as an uninterrupted sequence, traceable for thousands of meters, of alternating thin sandstone and mudstone beds (fig. $6 \mathrm{C}$ ), but elsewhere it crops out as an amorphous mass totally devoid of bedding.

Although other workers (Hardy, 1949; Hunt, 1950; Spieker, 1949, p. 17; Standlee, 1982, p. 363) have suggested that considerable limestone (Hardy's unit A) is in the Arapien Shale, I suggest that the formation, in fact, contains little actual limestone. The Arapien is certainly calcareous; the mudstone beds that compose the bulk of the formation contain much carbonate, but these mudstone beds are wholly different from the limestone beds other workers have included in the Arapien Shale.

The assumption that the Arapien Shale contains much limestone probably stems from geologic mapping at the north end of the Gunnison Plateau (Hunt, 1950). A major north-trending anticline is well exposed in Chicken and Pigeon Creeks along the northwest flank of the Gunnison Plateau, east of Levan (C-3). Exposed units consist of light-gray to gray, thin to massive, dense beds of fine-grained limestone. East of and abutting these limestone beds are drab-gray calcareous mudstone beds of the Arapien Shale. The limestone beds, much crumpled, were considered to be the lower part of the Arapien (Spieker, 1949 , p. 48), and the mudstone beds the upper part (Hardy, 1949, p. 16). Consequently, these limestone beds were grouped with the contiguous well-exposed mudstone beds of the Arapien Shale, and both units were mapped as the undivided Arapien Shale (Hunt, 1950).
I believe, however, that the limestone beds are correctly assigned to the Twin Creek Limestone of Middle Jurassic age (Bajocian to Callovian). Seemingly, long after these Twin Creek strata were thrust into position, probably as part of the Charleston-Nebo thrust plate, the Arapien Shale intruded, crumpled, and deformed them. Regrettably, the presence of Jurassic fossils in both units led to the two lithologies being assigned to one formation.

This infelicitous grouping led to a major misconception: that attitudes measured on Arapien Shale beds would give some indication of the configuration of the underlying, concealed Navajo Sandstone (also known as the Nugget Sandstone north of Thistle, Utah (A-5)), one of the major reservoir rocks in central Utah. In my opinion, however, contorted Arapien strata exposed in central Utah have been deformed too intensively too many times to indicate the configuration of the underlying strata. By contrast, where the limestone beds of the Twin Creek are exposed in the Chicken and Pigeon Creek area, attitudes measured on them do indeed indicate the configuration of the fold, and also reflect the attitude of the underlying Navajo Sandstone; they have no bearing on the attitude of the Arapien Shale which intrudes that fold, deforms it, and probably underlies it.

\section{CONTACT RELATIONS}

LOWER CONTACT

Although other workers (Spieker, 1949, p. 17; Moulton, 1975, p. 9; Picard, 1980, p. 131; Standlee, 1982 , p. 363) have stated that the Arapien Shale rests on the Navajo Sandstone, I believe that the Arapien rests on the Twin Creek Limestone. Seemingly, our different interpretations stem from the fact that these other workers have included the limestone beds, here considered to be the lower and medial parts of the Twin Creek Limestone, in the lower part of the Arapien Shale.

In Wyoming and northern Utah, the Twin Creek Limestone consists of seven members, which are, in ascending order: the Gypsum Spring, Sliderock, Rich, Boundary Ridge, Watton Canyon, Leeds Creek, and Giraffe Creek (Imlay, 1967). In central Utah, the series of sandstone and limestone beds intercalated between the Arapien and the Navajo Sandstone consist of the lower five members of the Twin Creek, in essence, from the Gypsum Spring up to and including the Watton Canyon. This Gypsum Spring to Watton Canyon sequence has been repeatedly cut by exploratory wells drilled by Placid Oil Company in the Juab and Sevier Valleys (Sprinkel, 1982). The sequence thins eastward. Although Arapien 
TABLE 3.-Correlation chart for some Middle Jurassic formations in central Utah

[Modified slightly from correlation charts prepared by Imlay (1980, p. 74), and D.A. Sprinkel (Placid Oil Company, written commun., 1981). Query, relationship uncertain]

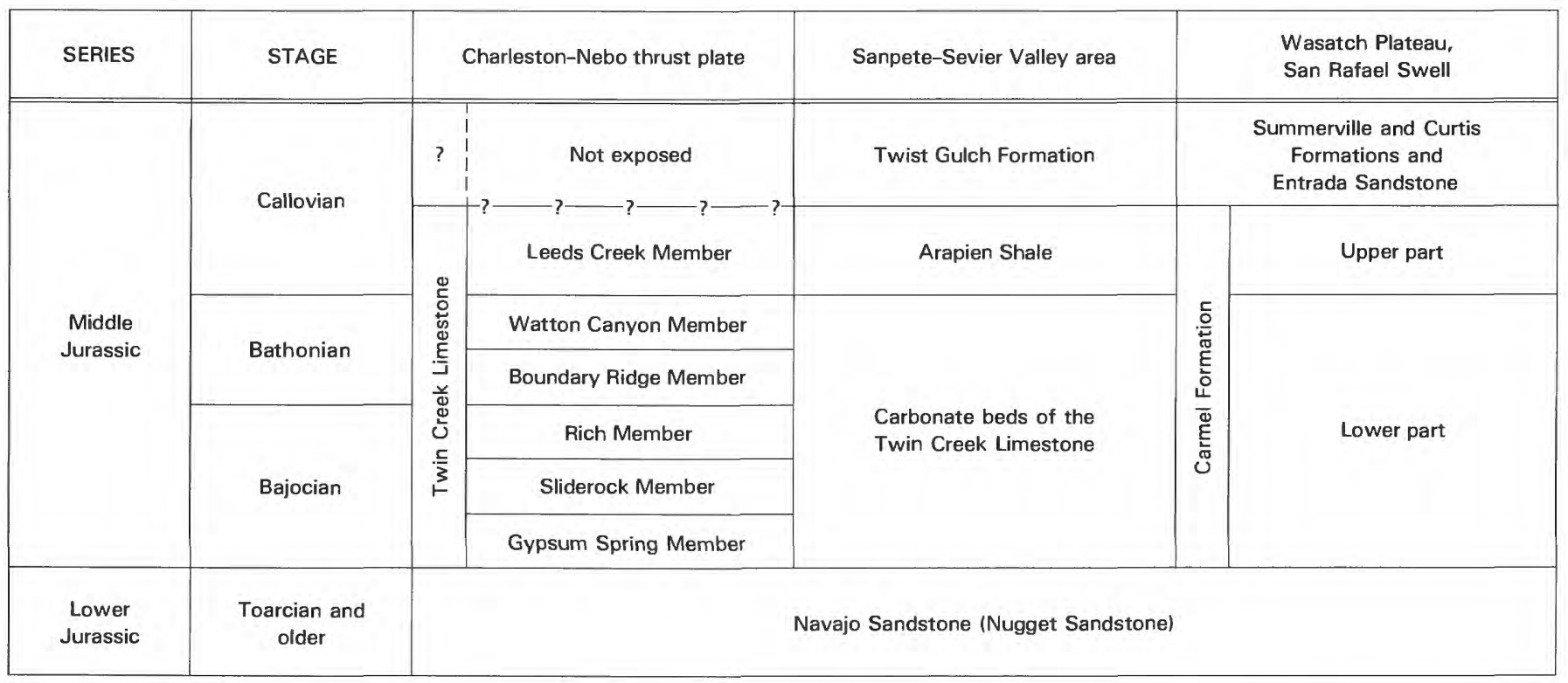

mudstone may locally rest on the Navajo Sandstone, in most localities throughout the Sanpete-Sevier Valley area, the mudstone probably rests on one or another of the members (Gypsum Spring to Watton Canyon) of the Twin Creek Limestone.

I suspect that this intercalated sequence of Twin Creek beds is correlative with the lower part of the Carmel Formation of the San Rafael Group. If so, the Arapien is probably correlative with the Leeds Creek Member of the Twin Creek Limestone-the member that commonly overlies the Watton Canyon. Table 3, modified from correlation charts prepared by Imlay (1980, p. 74 ), and by D.A. Sprinkel (1982), summarizes the stratigraphic relations between the Twin Creek Limestone and the Arapien Shale.

In Red Canyon (B-3) near Nephi (B-3), in the Thistle (A-5) area, and in the Pigeon Creek-Chicken Creek (C-3) area, the Arapien is underlain by beds of the Gypsum Spring to Watton Canyon sequence. I believe that in all three localities these Twin Creek units are part of the Charleston-Nebo thrust plate, and that they have been intruded and deformed by the adjacent Arapien Shale (Witkind, 1983, p. 51-54, 55; Witkind, 1987). Exposures in the three areas suggest that the Arapien, originally in its normal stratigraphic position, was mobilized, and, as a result, intruded and deformed the adjacent rocks.

\section{UPPER CONTACT}

Where exposed in central Utah a bewildering variety of units, ranging in age from Jurassic to
Holocene, overlies the Arapien Shale. This variety probably reflects the intrusive nature of the Arapien. The Twist Gulch Formation probably overlies the Arapien conformably; seemingly the two formations do not intertongue. In most localities where I have seen the contact, the Twist Gulch strata that overlie the Arapien have been turned on end or tilted upward moderately to steeply. Thus, in the Middle Fork Pole Creek (B-4) (east of Nephi), the Twist Gulch beds are vertical where they abut the Arapien (fig. 39). In the ancestral Willow Creek area (G-3) (northeast of Salina (G-3)), Twist Gulch beds that overlie the Arapien are inclined westward at dips that range from $35^{\circ}$ to $85^{\circ}$, and they abut vertical beds of the Flagstaff Limestone (fig. $6 \mathrm{~A}$ ). Although the contact between the Twist Gulch and the underlying Arapien, in both localities, appears conformable, I believe the beds of the Twist Gulch have been tilted upward by the upthrust mudstone beds, which have been forced upward by the driving salt.

In various localities throughout the Sanpete-Sevier Valley area, the Arapien is unconformably overlain by tilted oolitic limestone beds of the Green River Formation. These beds, integral parts of the flanks of salt-cored anticlines, dip away from the crests of these folds.

\section{AREAL EXTENT}

The Arapien Shale is exposed here and there throughout central Utah (fig. 8). The most extensive exposures are in the southern sector of the Sanpete- 
Sevier Valley area, chiefly in Sanpete, Sevier, and Juab Counties. There the Arapien is concentrated in three belts reflecting, in my opinion, the exposed cores of five major salt-cored anticlines, here called diapiric folds (fig. 8).

1. A northeast-trending broad belt of Arapien Shale, along the east side of the Sevier Valley, that extends into Sanpete Valley and reaches from near Richfield (I-1) on the south to near Manti (E-4) on the north. This is the exposed core of the SanpeteSevier Valley diapiric fold.

2. A much smaller and narrower belt of Arapien Shale, trending north, that crops out along the west side of the Sevier Valley. This belt, which extends from near Redmond ( $\mathrm{G}-3)$ on the south to near Gunnison $(F-3)$ on the north, is part of the exposed core of the Redmond diapiric fold.

3. Other extensive exposures of the Arapien Shale, along the west flank of the Gunnison Plateau, that extend around the north end of the plateau and into the north-trending sector of Salt Creek canyon (B-3). These outcrops form parts of the cores of the Levan, Footes, and Pole Creek diapiric folds. As these Arapien exposures along the west flank of the Gunnison Plateau appear to align with similar outcrops farther south that form the core of the Redmond diapiric fold, it may be that the Levan and Redmond folds are joined in the subsurface.

In the northern sector of the area, a few small, isolated Arapien exposures are between Indianola (B-5) and Thistle (A-5). Most of these exposures are part of the Thistle Creek diapiric fold.

Although the three belts represent the major outcrops of the Arapien Shale, the Arapien probably underlies a large area. Just how large, however, is difficult to determine. Test wells indicate that the Arapien underlies much of Sanpete Valley; apparently the core of the Sanpete-Sevier Valley diapiric fold continues northward beyond Manti (E-4) but is concealed beneath the surficial deposits that floor the valley.

The Arapien Shale may also underlie all of central Sevier Valley (that sector between the Valley Mountains $(\mathrm{G}-2)$ on the west and the Wasatch Plateau (F5) on the east) possibly at shallow depth. At least one water well in the valley, near Centerfield ( $F-3$ ), penetrated red shale and found saline water at a depth of about $165 \mathrm{~m} \mathrm{(550} \mathrm{ft)} \mathrm{(Gilliland,} \mathrm{1948,}$ p. 109).

The exposures of the Arapien Shale in Salt Creek (B-3) seemingly are concealed beneath the CharlestonNebo thrust plate (Witkind, 1983, p. 51-54; this report, fig. 35). How far to the north the Arapien extends beneath the thrust plate is unknown. Deformation along an erosional escarpment along the east flank of the thrust plate has led me to suggest that the Arapien extends at least as far north as Payson Canyon (A-4) (Witkind, 1987). Northeast of Salt Creek, the Arapien crops out near Thistle (A-5), and there too, the field relations imply that the unit is concealed beneath the Charleston-Nebo thrust plate (Witkind, 1983, p. 55; Witkind, 1988; this report, fig. 44). I am uncertain how far the Arapien extends to the north beyond Thistle. Possibly the salt in the lower part of the Preuss Sandstone, of southwestern Wyoming and northern Utah, may be correlative with the uppermost units of the Arapien Shale. Probably, the bulk of the Preuss correlates with the Twist Gulch Formation of central Utah.

I am also uncertain how far the Arapien extends to the east. If the many north- and northeast-trending grabens that mark the crest of the Wasatch Plateau do stem from dissolution of salt beds, as proposed by Stokes and Holmes (1954, p. 40), and implied by Walton (1955, p. 409-410), the Arapien may once have reached at least as far east as a north-trending line through Scofield Reservoir (B-6). I, too, favor the concept that the many grabens and high-angle faults that break the crest of the Wasatch Plateau are the result of dissolution of salt beds once contained within the Arapien Shale. Several proprietary seismic reflection profiles that I have examined through the courtesy of Chevron Oil Company convince me that the faults do not extend below the Arapien and Carmel Formations. Walton (1955), discussing the gas fields of the Wasatch Plateau, cited a thickness of $375 \mathrm{~m}(1,230 \mathrm{ft})$ of highly contorted Arapien (1955, p. 398) cut by the Gordon Creek well (fig. 9). This well, in the SE1/4 NE 1/4 sec. 24 , T. 14 S., R. 7 E., was drilled about $19 \mathrm{~km}(12 \mathrm{mi})$ southeast of the Scofield Reservoir (B-6). Both Moulton (1975, fig. 13), and Stokes (1982, fig. 1) have drawn the zero isopach of the salt near the east edge of the Wasatch Plateau.

To the south the Arapien Shale disappears beneath volcanic flows east of Richfield (I-1). Little evidence indicates how far south the Arapien persists beneath this volcanic mantle. The Paxton No. 1 test well (SW $1 / 4 \mathrm{NW}^{1 / 4}$ sec. 28 , T. 23 S., R. 3 W.) (fig. 9), drilled by Placid Oil Company near Elsinore (a small community about $16 \mathrm{~km}$ (10 mi) south of Richfield), penetrated both mudstone beds and salt of the Arapien Shale.

The western extent of the Arapien, too, is uncertain. Recent drilling in the Valley Mountains (G-2), in Round Valley ( $\mathrm{F}-2$ ), and in the West Hills (D-2) indicates that the Arapien extends at least as far west as the east flanks of the Pavant Range ( $\mathrm{H}-1)$ and Canyon Mountains (E-1). Brown and Cook (1982, p. 123) proposed, on the basis of gravity data, that the 


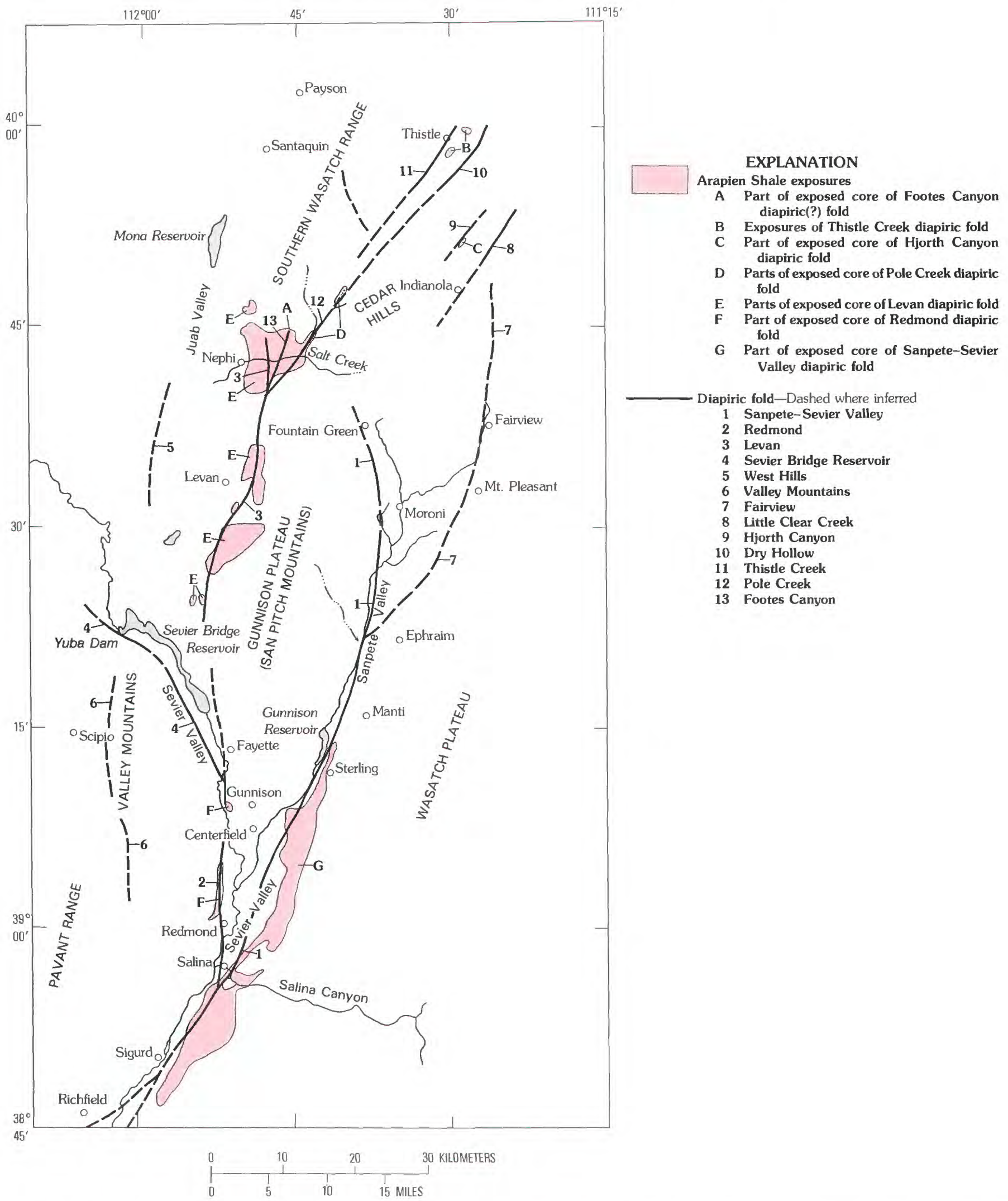

FIGURE 8.-Distribution of Arapien Shale exposures throughout the Sanpete-Sevier Valley area. These exposures represent parts of 7 of the 13 major diapiric folds (salt-cored anticlines) recognized. Base from Grand Junction (T-3) Sectional Aeronautical Chart, U.S. Coast and Geodetic Survey (1954, rev.). 
Arapien lenses out under the Pavant Range. Eardley (1969, p. 58, fig. 2), however, seemingly considered the Arapien to underlie the Pavant Range; and if this is correct, the Arapien may extend still farther west, at least to the east edge of the Sevier Desert. Deformation along the northeast flank of the Valley Mountains suggests that a major diapiric fold reaches as far west as Yuba Dam (E-2) and probably extends much farther to the west (Witkind and Page, 1984).

In summary, then, it would appear that in central Utah the Arapien Shale underlies an area of at least $11,700 \mathrm{~km}^{2}\left(4,500 \mathrm{mi}^{2}\right)$. On the basis of exposures or test-well data, the Arapien extends westward some 80 $\mathrm{km}(50 \mathrm{mi})$ from the Wasatch Plateau to the Canyon Mountains and the Pavant Range. It extends southward some $150 \mathrm{~km}(90 \mathrm{mi})$ from Thistle (A-5) on the north to near Elsinore on the south. I suspect that the Arapien underlies a vastly larger area.

Arapien Embayment And The Arapien Basin

Sprinkel and Waanders (1984) have suggested that most of Utah, during Middle Jurassic time (Bajocian, Bathonian, and Callovian), was the site of a large marine embayment, which they named the "Arapien embayment." As visualized by them, the embayment probably extended westward into what is now eastern Nevada, northward into southern Idaho, southward at least as far as northern Arizona, and eastward to the Utah State line. Highlands on the west, south, and east flanked the embayment during its early stages. Subsequently, as an uplift, now known as the Uinta Mountains, rose above sea level, the embayment also became confined on the north.

During the early stages of the embayment, carbonates were deposited that now form the lower and medial parts of the Twin Creek Limestone interval. Most likely, the lower five members-the Gypsum Spring, Sliderock, Rich, Boundary Ridge, and Watton Canyon Members-of the seven members of the Twin Creek Limestone were formed during that time. Subsequently, the embayment shrank to form a smaller basin-the Arapien basin of Stokes (1982)-and shallow-water and saline deposits, the bulk of the Arapien Shale, formed in that basin under hypersaline conditions. Apparently, Arapien mudstones and evaporites were being deposited even as units of the Leeds Creek Member of the Twin Creek, above the Watton Canyon, were forming in deeper waters marginal to the basin.

The extent of the Arapien basin is problematical. Stokes (1982, fig. 1) suggested that it occupied most of Sevier and Sanpete Counties. Sprinkel and Waanders, on the basis of isopach maps, chiefly of
Arapien strata, proposed that the basin was considerably larger. In their view, the basin occupied most of central Utah, reaching as far north as Provo, as far east as Green River, as far south as St. George, and as far west as Delta. The deepest part of the basin underlay Sanpete and Sevier Counties; presumably most of the evaporites accumulated there.

Much salt must have been deposited in the Arapien basin, and large volumes of that salt must have been dissolved and moved elsewhere. Indeed, that an Oligocene salt diapir was penetrated by the Argonaut-Federal well near Delta, far to the west of the Sanpete-Sevier Valley area (p. 24), implies such dissolution and mobilization of the Jurassic salt. Although Standlee (1982) has argued that the well data for central Utah indicate only relatively minor to moderate amounts of salt-in essence, insufficient salt to support the salt diapiric concept-the critical factor is not the amount of salt currently available, but rather the amount of salt that was available in the geologic past.

Moulton (1975, p. 90, and fig. 13), prior to the work of Sprinkel and Waanders, and of Stokes, had speculated that the depocenter for much of the Arapien Shale must have been a northeastward trending rift valley, which Moulton named the "Sanpete-Sevier rift." In his view, the rift, bounded by growth faults, contained the thickest accumulations of salt and was filled with about $3,350 \mathrm{~m}(11,000 \mathrm{ft})$ of evaporites and shales. Moulton believed that the east edge of the rift was delineated by an "ancient Ephraim fault," and, thus, he saw the saline basin as being essentially asymmetric - deepest along its east edge-as a result of repeated movement along this ancient fault. In Moulton's view (1975, p. 91), the ancient Ephraim fault has been inactive since Middle Jurassic time. Picard (1980, p. 133) objected to the concept of a rift valley and proposed that the basin be termed instead a "Jurassic marginal basin." $\mathrm{He}$ believed that the position of the basin and its general shape were determined by the regional uplift of a western Mesocordilleran anticline.

\section{CONTAINED SALT}

LITHOLOGY

Salt is mined from the Arapien Shale near Redmond (G-3), and is exposed in the mines there; salt also crops out in several small salt mines in Salina Canyon (H-3) east of Salina (G-3). As far as known, salt is not exposed elsewhere in this part of central Utah, although it was mined by the Great Western Salt Company from pits some $8 \mathrm{~km}(5 \mathrm{mi})$ northeast 
of Salina. Salt was also mined near Sterling (F-4), and from two rock-salt pits in the Arapien Shale along the north bank of Salt Spring Creek (a tributary to the North Fork of Salt Creek), some $11 \mathrm{~km}$ ( $7 \mathrm{mi}$ ) east of Nephi (B-3). In all localities, the salt is intercalated with mudstone beds of the Arapien Shale, chiefly red shaly siltstone and earthy material, probably correlative with Hardy's unit E. Its great extent, however, is evident in the names the early settlers gave to the creeks and communities in central Utah-Salt Creek, Little Salt Creek, Salina.

Picard (1980, p. 145), has described the salt in the Redmond area: "In general appearance, the salt is massive and coarse-grained. $* * *$ because of the intense deformation and flowage much of the salt is oriented and drawn out into acicular crystals $* * *$.

The salt is ordinary halite, but tinted a pale to deep reddish brown by disseminated clay particles.

Although the salt exposed in the Redmond mines is highly deformed, at least one small salt mine east of Salina exposes bedded salt-somewhat of a surprise, for one might not expect bedded salt in an area marked by intense and repeated diapiric activity. Jackson (1985, p. 4), however, discussing Iranian diapirs, noted that although most of the Iranian salt is intensely deformed, some $" * * *$ *ock salt is horizontally stratified in some diapirs* * *suggesting emplacement in a pistonlike manner with little internal deformation***."

THICKNESS OF SAIT

Where exposed in most places the salt is much crumpled and contorted; near Redmond (G-3), for example, the salt beds are vertical, and may range in thickness from 180 to $300 \mathrm{~m}$ (600 to $1,000 \mathrm{ft}$ ) (Pratt and others, 1966, p. 54). One bed being mined in the Redmond area in 1980 was about $60 \mathrm{~m}(200 \mathrm{ft})$ thick (Picard, 1980, p. 145).

Although the drilling that has been done in central Utah demonstrates that salt is widespread in the subsurface (Moulton, 1975; Standlee, 1982, fig. 5), little salt is exposed at the surface. Probably this lack of surface exposures is due to the extreme solubility of the salt; no sooner is it exposed than it is dissolved and removed. Pratt and his co-workers (1966, p. 55) have suggested that the salinity of Great Salt Lake may stem in some measure from the solution of exposed Arapien salt by the ancestral Sevier River, which flowed north and discharged into Lake Bonneville during Pleistocene time.

The salt diapir cut by the Argonaut-Federal well (C, NW, sec. 23, T. 15 S., R. 7 W., Millard County), near Delta (some $70 \mathrm{~km}(45 \mathrm{mi})$ northwest of the Sanpete-Sevier Valley area), also suggests dissolution and transport of Arapien salt. This well passed through some $1,570 \mathrm{~m}(5,152 \mathrm{ft})$ of salt (Mitchell, 1979 , p. 505). On the basis of palynological studies and fission-track dating of intercalated volcanics, the basin sediments penetrated by the well have been tentatively dated as late Oligocene (Lindsey and others, 1981). The salt, part of these basin sediments, has been interpreted as former Mesozoic salt deposited during Oligocene-Miocene time in the large ancestral Sevier Lake into which the ancestral Sevier River emptied (Mitchell, 1979, p. 505-508). Presumably when the salt-rich units of the Arapien Shale in this part of central Utah broke through to the surface during the late Oligocene or Miocene, the exposed salt was dissolved by the ancestral San Pitch and Sevier Rivers and their tributaries, carried north and west around the north ends of both the Valley (G-2) and Canyon (E-1) Mountains, and discharged into ancestral Sevier Lake. Subsequent evaporation resulted in the deposition of the salt, which eventually migrated laterally to form the discrete diapir drilled by the Argonaut-Federal well. I believe that many other salt diapirs, comparable to the one penetrated by the Argonaut-Federal well, are in the general area near Sevier Lake.

Other workers have assumed that although salt is in the area, there just was not enough for it to have played any significant role in the structural development of central Utah (Gilliland, 1963, p. 123; Standlee, 1982; Lawton, 1985). I suggest instead that large amounts of salt have been removed from the area in the past and that large amounts still underlie the area. The Phillips Price "N" well, in Sanpete Valley near Moroni (D-4) (fig. 9) ( $\mathrm{SE} 1 / 4 \mathrm{SE} 1 / 4$ sec. 29, T. 15 S., R. 3 E.), penetrated salt and interbedded subordinate calcareous mudstone some $621 \mathrm{~m}(2,038$ ft) thick. Near Salina (G-3), the Chevron U.S.A. Salina Unit No. 1 well (sec. 33, T. 22 S., R. 1 W.) cut more than $300 \mathrm{~m}(1,000 \mathrm{ft})$ of salt and interbedded mudstone (Standlee, 1982, p. 366). In the West Hills (D-2), west of Juab Valley, Placid Oil Company's Howard 1-A WXC well ( $\mathrm{NE} 1 / 4 \mathrm{NW}_{1 / 4}$ sec. 5, T. 14 S., R. $1 \mathrm{~W}$.) cut about $170 \mathrm{~m}(550 \mathrm{ft})$ of salt. And Chevron's Chriss Canyon No. 1 well (NE $1 / 4 \mathrm{SW}_{1 / 4}$ sec. 33, T. 16 N., R. 1 E.), near the center of the Gunnison Plateau (D-3), cut through about $245 \mathrm{~m}(800 \mathrm{ft})$ of salt (Standlee, 1982, p. 362).

Moulton's (1975, fig. 13) isopach map shows the distribution and thickness of the salt. His sparse data show a remarkable lack of uniformity, suggesting that the salt varies greatly in thickness. Data from test wells indicate that great thicknesses of salt give way 
laterally to zones that either contain no salt or contain but thin salt stringers. So, although the Price "N" well penetrated a great thickness of salt, the Moroni wells (sec. 14, T. 15 S., R. 3 E.), only $5 \mathrm{~km}$ ( $3 \mathrm{mi})$ to the east, found none, even though they cut great thicknesses of Arapien mudstone. In like fashion, the State No. 1 well (sec. 36, T. 15 S., R. 1.5 W.) cut through $1,050 \mathrm{~m}(3,450 \mathrm{ft})$ of salt. The Monroe 13-7 well (sec. 13 , T. 16 S., R. 2 W.), about $5 \mathrm{~km}$ (3 mi) to the southeast, cut only about $210 \mathrm{~m}(688 \mathrm{ft})$ of salt, and the Barton No. 1 (sec. 32, T. 16 S., R. 1 W.) well, about $8 \mathrm{~km}(5 \mathrm{mi})$ southeast of the Monroe well, found none, even though it drilled great thicknesses of Arapien mudstone.

It seems to me that the absence of salt from some wells does not necessarily mean nondeposition, or areally erratic dissolution, but rather lateral migration of salt toward the diapirs. Much of the salt, thus, may now be in the diapirs. Those wells that cut great thicknesses of salt, such as the Phillips Price "N" well, or Chevron's U.S.A. Salina Unit No. 1 (sec. 33, T. 22 S., R. 1 W.), probably are near the axial part of a diapiric fold (fig. 5). Those wells that found no salt but did drill through much mudstone (such as the Hanson wells) either are along the flanks of the diapiric core, or have drilled into localities where the source ("mother") bed of salt has been depleted. As Sannemann (1968) noted, once salt diapirs begin to form, the bedded salt migrates laterally toward the rising salt stocks (diapirs). It seems unreasonable to assume that salt was deposited only in restricted areas of the large Arapien basin.

Furthermore, the amount of salt found throughout the area now may have little or no bearing on the purported thickness of the salt. The critical factor is the amount of salt that was available during the times the diapiric folds were formed. Much of the salt that was present then may have been removed as a result of either dissolution or extrusion.

This migration of the salt may be the result of autonomous, isostatic movement (halo-kinesis), or the result of tectonic impulses (halo-tectonism) (Trusheim, 1957; see also pages 129 and 131).

\section{THICKNESS OF ARAPIEN SHALE}

In most exposures the Arapien Shale is greatly deformed; crumpled and contorted beds are widespread, small folds accompany larger ones, and overturned folds are common (fig. 10). Deformation is intense, and so many beds are repeated that the original thickness of the Arapien is uncertain; estimates range from 1,200 to $4,000 \mathrm{~m}(4,000$ to $13,000 \mathrm{ft})$ (Spieker, 1949, p. 17; Gilliland, 1948, p. 30; 1951, p. 11; Hardy, 1949, p. 16, 17; Eardley, 1933a, p. 331; Standlee, 1982, p. 363). Standlee (1982, p. 363), in particular, suggested that a thickness of about $1,675 \mathrm{~m}(5,500 \mathrm{ft})$ " **** *losely approximate $(\mathrm{s})$ the original stratigraphic thickness of the Arapien $* * *$ in the Gunnison Plateau region." Standlee's thicknesses, based on the Dixel Resources and the Chevron U.S.A. Chriss Canyon wells (fig. 9), include oolitic limestone beds that I assign instead to the Twin Creek Limestone. Thus, his Arapien includes not only Arapien mudstones but also Twin Creek limestones.

I doubt whether any of the thicknesses cited above is a reliable indicator of the original thickness of the Arapien. The Arapien is probably thickest near the axes of the diapiric folds, thinnest between them.

\section{AGE}

The Arapien Shale is of Middle Jurassic (Callovian) depositional age. Formerly the Arapien was assigned to the Bathonian (Witkind and Hardy, 1984). Sprinkel and Waanders (1984, p. 950), through study of the Twin Creek and Arapien relations, identified three distinct dinoflagellate assemblages which they assigned to the Bajocian(?), Bathonian, and Callovian Stages of the Middle Jurassic. The Bajocian(?) assemblage characterizes the lower part of the Twin Creek sequence, essentially the Sliderock and Rich Members. The Bathonian assemblage marks the medial part of the Twin Creek, chiefly the Boundary Ridge and Watton Canyon Members. And the Callovian assemblage is found in the Arapien Shale (Waanders and Sprinkel, 1984)-additional support for the contention that the Arapien is essentially equivalent to the Leeds Creek Member.

Although the Arapien Shale was deposited during the Middle Jurassic, its age seemingly has changed throughout geologic time. In places, it deforms Cretaceous beds, elsewhere Eocene or Oligocene strata, and in several places it probably has deformed Pliocene or Quaternary units. Thus, although its depositional age is Middle Jurassic; its emplacement ages have changed repeatedly. To indicate the several emplacement ages, I have, on a published map (Witkind, 1981), and on figures in other published articles (Witkind, 1982; 1983), used such symbols as "O(Jat)," "K(Jat)," and "T(Jat)" to indicate the major times ( $\mathrm{Q}=$ Quaternary, $\mathrm{K}=$ Cretaceous, and $\mathrm{T}=$ Tertiary) during which the country rocks were deformed by the upward movement of the Arapien Shale (formerly known as the Twelvemile Canyon Member of the Arapien Shale; $\mathrm{J}=J$ urassic, $\mathrm{a}=$ Arapien Shale, $\mathrm{t}=$ Twelvemile Canyon Member). In this paper I have omitted the " $t$ " from the 


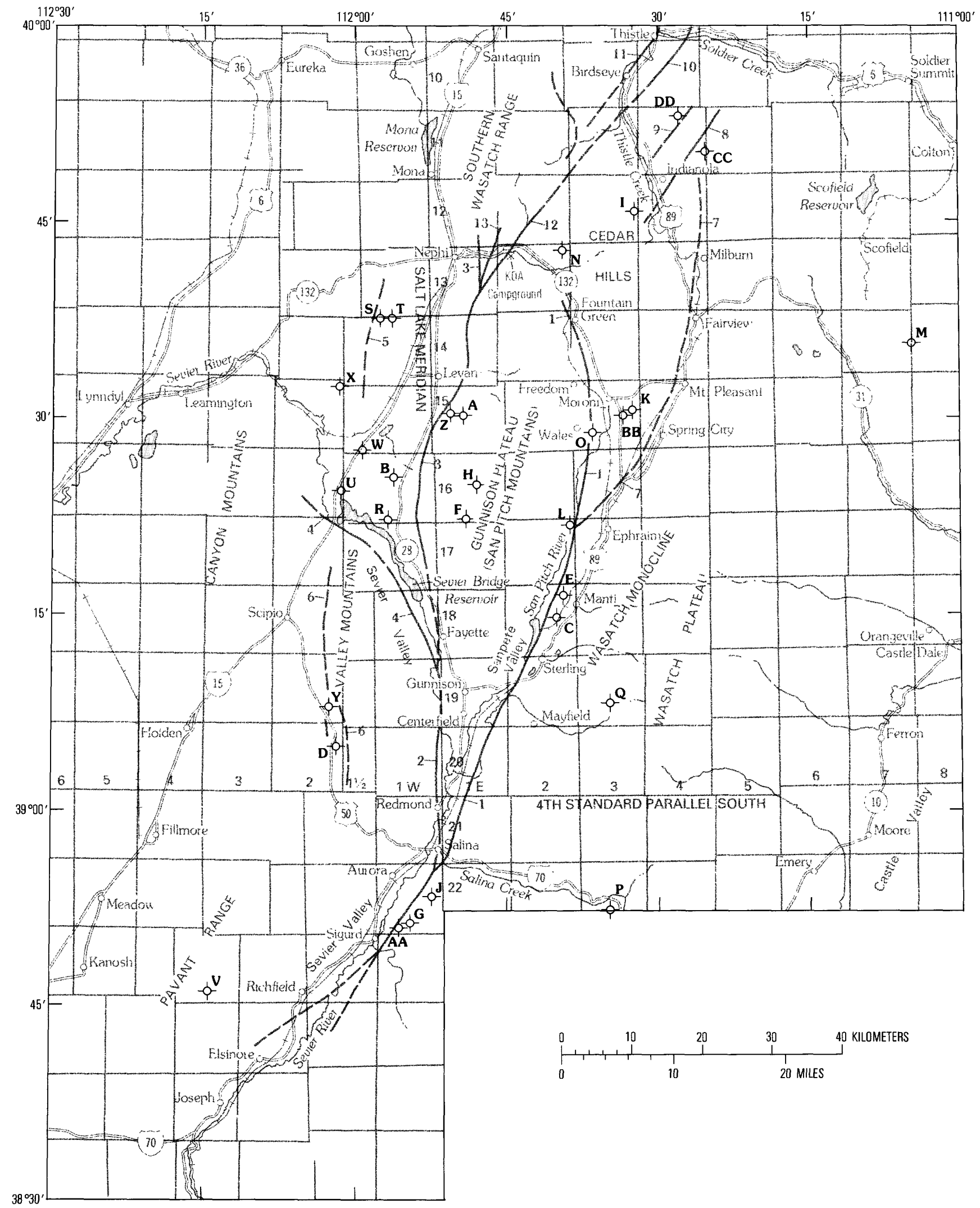

FIGURE 9 (above and facing page).-Major test wells in central Utah, and their spatial relation to recognized diapiric folds. All wells are approximately located. Index $A$, location of figure 9 ; index $B$, general structural setting. 


\section{EXPLANATION}

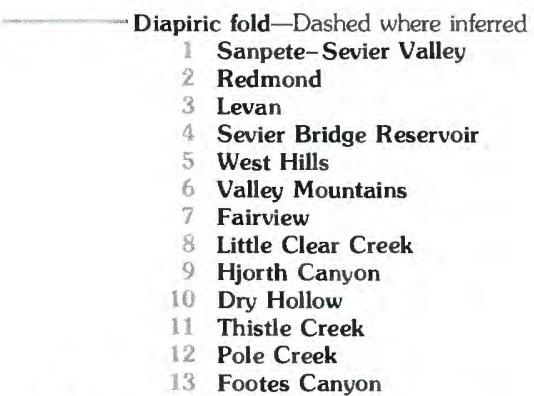

B Well names and locations (Listed alphabetically)

A American Quasar-Chicken Creek Fed. No. 16-34, sec. 16, T. 15 S., R. 1 E.

B Amoco-Sevier Bridge No. 1, sec. 11, T. 16 S., R. 1 W.

C Anderson No. 13-14, sec. 14, T. 18 S., R. 2 E.

D Anschutz Corp., Williams Energy Monroe Fee No. 1, sec. 14 , T. 20 S., R. 2 W.

E Chandler and Assoc.-Barton No. 4-2, sec. 2, T. $18 \mathrm{~S}$. R. $2 \mathrm{E}$.

F Chevron U.S.A.-Chriss Canyon No. 1, sec. 33, T. 16 S., R. 1 E.

G Chevron U.S.A.-Salina Unit No. 1, sec. 33, T. 22 S. R. $1 \mathrm{~W}$.

H Dixel Resources-Gunnison State No. 1, sec. 15, T. 16 S., R. 1 E.

I Exxon-Mt. Baldy, sec. 24, T. 12 S., R. 3 E

J Forest-Sigurd No. 1, sec. 14, T. 22 S., R. 1 W.

K Hanson-Moroni No. 1, sec. 14, T. 15 S., R. 3 E.

L Mobil-Larson No. 1, sec. 1, T. 17 S., R. 2 E.

M Pacific Western-Gordon Creek No. 1, sec. 24, T. 14 S., R. 7 E.

N Phillips Petroleum-Nielson, sec. 1, T. 13 S., R. 2 E.

O Phillips Petroleum-Price "N", sec. 29, T. 15 S., R. 3 E.

P Phillips Petroleum-USA "D", sec. 20, T. 22 S., R. 3 E.

Q Phillips Petroleum-USA "E", sec. 27, T. 19 S., R. 3 E.

$R$ Placid-Barton No. 1, sec. 32, T. 16 S., R. 1 W.

S Placid-Howard 1-A WXC, sec. 5, T. 14 S., R. 1 W.

T Placid-Howard 2 WXC, sec. 5, T. 14 S., R. 1 W.

U Placid-Monroe No. 13-7, sec. 13, T. 16 S., R. 2 W.

V Placid-Paxton No. 1, sec. 28, T. 23 S., R. 3 W.

W Placid-State No. 1 WXC, sec. 36, T. 15 S., R. 1.5 W.

$X$ Placid-State No. 2 WXC, sec. 1, T. 15 S., R. 2 W.

Y Placid-USA-1-2 WXC, sec. 24, T. 19 S., R. 2 W.

Z Standard Oil of California-Levan Unit No. 1, sec. 17, T. 15 S., R. $1 \mathrm{E}$

AA Standard Oil of California-Sigurd No. 1, sec. 32, T 22 S., R. 1 W.

BB Tennessee Gas Transmission-J.W. Irons No. 1, sec. 16, T. 15 S., R. 3 E.

CC Union Oil-G-24, sec, 24, T, 11 S., R. 4 E.

DD Union Oil-J-9, sec. 9, T. 11 S., R. 4 E.
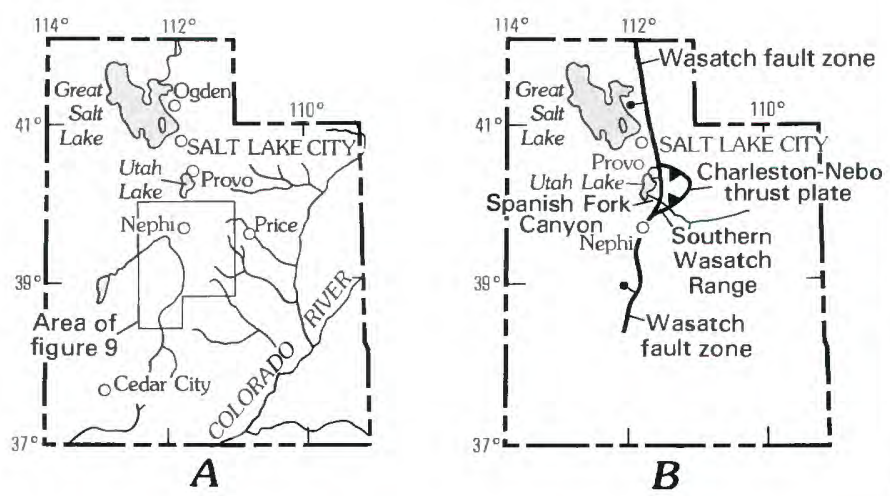

symbol to conform with the recent Witkind-Hardy (1984) proposal that the name "Twelvemile Canyon Member" be abandoned and its units be known simply as the "Arapien Shale" (p. 16).

\section{DIAPIRIC STRUCTURES}

\section{INTRUSIVE ASPECTS OF THE ARAPIEN SHALE}

The evidence I have seen in central Utah suggests that the salt in the Arapien Shale has been moving since shortly after it was deposited, and may well be moving today. Some of this movement has been a slow, continuous, persistent upwelling, best demonstrated by the anomalous thinning of sequences of sedimentary units near the crests of major upwarps, but at times the salt seemingly has moved upward rapidly. ${ }^{2}$ During these rapid upward movements the salt has acted much like a viscous fluid and has repeatedly pushed the enveloping Arapien mudstones both vertically and laterally, forcing them to intrude and deform, and locally to bow up and break the overlying sedimentary beds. Although I describe the Arapien Shale as an intrusive sedimentary unit, it is mainly the salt that is intrusive; the mudstones, shales, and other lithologic units of the Arapien, essentially passive, have been forced upward and laterally by the dynamic salt. Salt is the driving force, driven to some extent by buoyancy, and to some extent by static load stemming from the gradual accumulation of sediments in nearby areas. An analogy that comes readily to mind is that of a hydraulic car jack. The salt represents the hydraulic fluid, the Arapien mudstones and shales, the bearing platform of the jack, and the uplifted younger strata, the car. The buoyancy and static load, in this analogy, represent the mechanism that pumps the fluid-in essence, the person laboriously raising and lowering the handle of the car jack.

Locally, where the beds have been bowed up, folded back, and overturned, the uppermost (older) beds have been shoved along bedding planes and across the underlying (younger) beds to create a series of both low- and high-angle reverse faults of minor displacement. Seemingly, the upward movements of the Arapien mudstone beds have been translated laterally into localized horizontal compressional forces. This has resulted in the many features along the east flank of the Gunnison Plateau (Weiss, 1982), or along the northeast flank of the Valley Mountains, that

${ }^{2}$ I use the term "rapid" in the context of geologic time. The upward movements I visualize are not sudden, cataclysmic events. The salt-generated folds described in this report probably developed quickly when contrasted with the time needed to form most other geologic features. 

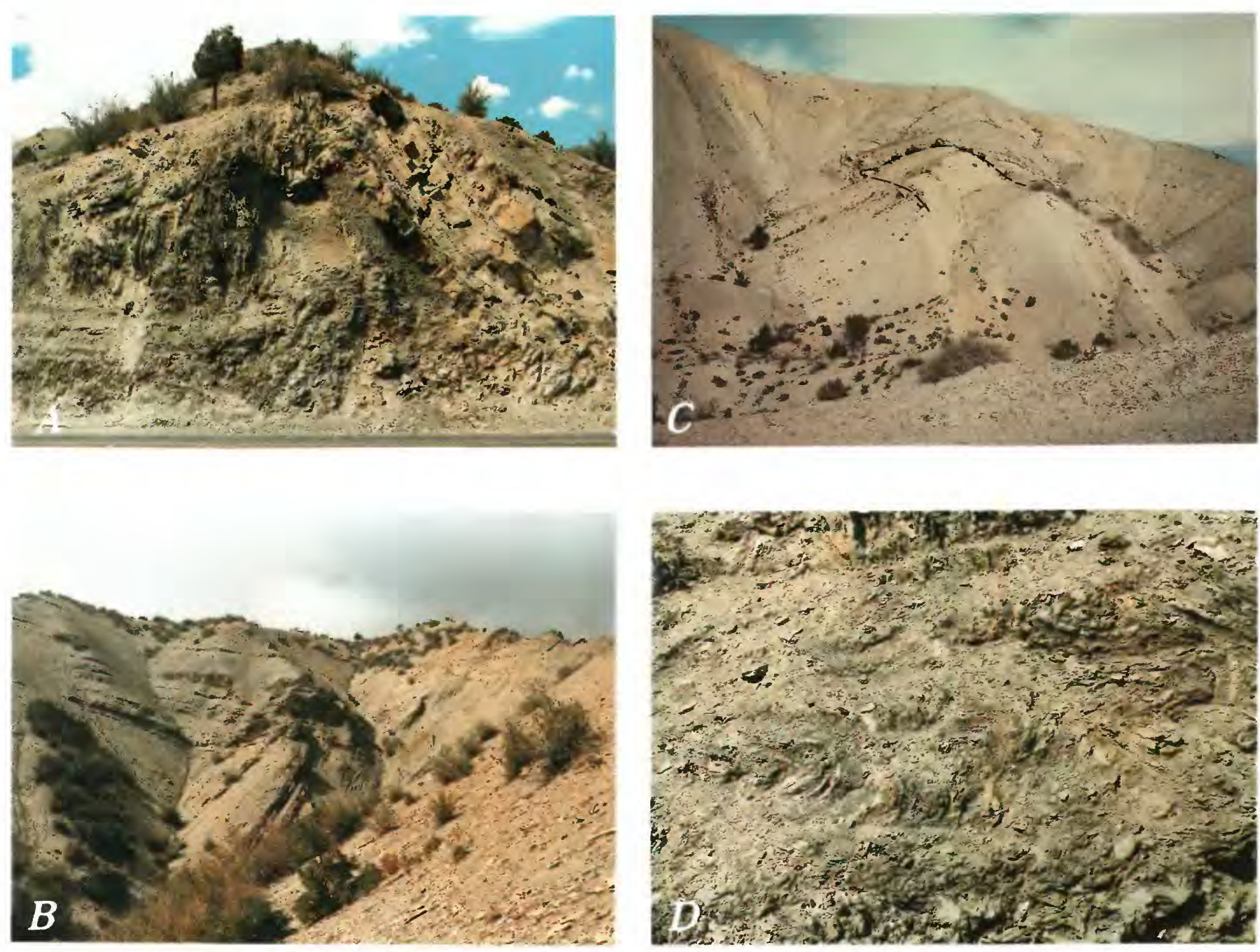

Figure 10.-Deformed beds of the Arapien Shale. A, Crumpled and contorted light-gray to gray mudstone and shaly siltstone beds of the Arapien Shale exposed in Salt Creek canyon along north side of Utah Highway 132, about $5 \mathrm{~km}$ ( $3 \mathrm{mi}$ ) east of Nephi. $B$, Overturned beds of the Arapien Shale exposed along Utah Highway 132 , about $5 \mathrm{~km}$ ( $3 \mathrm{mi}$ ) east of Nephi. C, Overturned fold (dashed line) in the Arapien Shale exposed in the White Hills

near Mayfield. Photograph by Mathis Zimmermann, ElfAquitaine Oil Company. $D$, Intricate deformation within the crumpled mudstone and siltstone beds of the Arapien Shale. Comparable large- and small-scale deformation is common throughout the Sanpete-Sevier Valley area, implying that the Arapien Shale is more or less deformed in central Utah.

suggest repeated compression from the east. Examples are the many minor "thrust faults" in which older, overturned units have been shoved westward onto younger right-side-up beds (Weiss, 1982), and the Z-fold in Dry Canyon (along the east flank of the Gunnison Plateau) (Spieker, 1949, p. 75), which reflects westward-directed compression.

The Arapien mudstone beds have been deformed so many times by their contained salt that their present attitude merely reflects the last episode of salt movement. The next diapiric episode will distort them once more into new and different attitudes.

Evidence of the mobile and intrusive nature of the Arapien Shale is widespread. On a small scale are minor structures, such as "dikes" and "sills" of Arapien Shale in country rock (figs. 11 and 46), that seem reasonably explained only by visualizing the Arapien Shale as an intrusive unit. On a large scale are the steeply tilted to overturned sedimentary beds that not only extend along strike for long distances but also flank those Arapien outcrops that I interpret as the cores of the major diapiric folds. This is perhaps most dramatically shown near Sterling ( $\mathrm{F}-4)$, where to the west, in and near the Red Rocks (F-3) 
area (fig. 19), those conglomerate beds in the Indianola Group that form the southeast flank of the Gunnison Plateau stand vertical or are overturned. East of Sterling, in Sixmile Creek canyon (F-4) (fig. 21), Indianola equivalents are also vertical or dip steeply eastward. Between these two sequences of steeply tilted beds, which I interpret as the west and east flanks respectively of the Sanpete-Sevier Valley diapiric fold, are the contorted shale and mudstone beds of the Arapien Shale - the core of the fold.

The plastic and mobile aspects of the Arapien were noted by previous workers. So, for example, Spieker (1949, p. 68), impressed by the fact that the soft Arapien Shale formed hills even as the more resistant units were planed off, commented: “****the cheese-like shale rose under pressure while the more resistant sandstones stood firm." It is clear from Spieker's discussion, however, that, in his mind, the responsible forces were orogenic in nature, and wholly unrelated to the salt in the Arapien. Gilliland (1963, p. 122), also impressed by the high mobility of the Arapien Shale, attributed the development of the Sanpete-Sevier Valley anticline (my Sanpete-Sevier Valley diapiric fold) to flowage of the Arapien into the axial part of the anticline. He attributed the flowage to a combination of compressional forces and geostatic load, and noted: "****although salt and gypsum certainly must have aided in the growth of the anticline, their role was minor."

In the following pages, I first describe several minor structures that display the intrusive characteristics of the Arapien Shale (p. 29-37), then describe the huge diapiric folds that dominate this sector of central Utah (p. 37-102), and finally suggest how I believe the diapiric folds grew and collapsed (p. 117132).

\section{MINOR STRUCTURES}

\section{THISTLE AREA}

The intrusive aspects of the Arapien Shale are well shown in the Thistle (A-5) area. As a result of the disastrous Thistle landslide of April 1983 (Duncan and others, 1986; Kaliser and Fleming, 1986), a new segment of U.S. Highway 6 and 89 had to be cut through a large hogback known locally, and erroneously, as Billies Mountain. ${ }^{3}$ The hogback, in sec. 28, T. $9 \mathrm{~S}$., R. 4 E., is east of the landslide and consists of

${ }^{3}$ The crews involved in the conversion of the Thistle landslide into an earthfilled dam (Thistle dam), and in the construction of the new segment of U.S. Highway 6 and 89, incorrectly called the ridge "Billies Mountain." In fact, Billies Mountain is some $3 \mathrm{~km}(2 \mathrm{mi})$ northeast of the ridge. Continued incorrect usage has transferred the name Billies Mountain to the hogback. the Navajo Sandstone overlain by Twin Creek Limestone, both of which dip steeply eastward. These units are part of the eastern mass of the CharlestonNebo thrust plate, and an erosional escarpment has been cut across them (Witkind, 1988, p. 86 and fig. 2). The escarpment is partly concealed beneath a series of Cretaceous and Tertiary units, chiefly beds of the North Horn, Flagstaff, and Colton Formations that unconformably overlie the Navajo and Twin Creek strata. The new segment of U.S. Highway 6 and 89, that cuts through the Twin Creek beds, exposed large and small irregular wedgelike masses of Arapien Shale that not only intrude and deform the limestone beds of the Twin Creek (fig. 11A), but also follow the unconformable contact between the Twin Creek and the overlying Colton Formation (fig. 11B).

\section{DOME NEAR ANCESTRAL WILLOW CREEK}

A small, elongate dome about $8 \mathrm{~km}(5 \mathrm{mi})$ northeast of Salina (G-3), occupies the $\mathrm{SE} 1 / 4$ sec. 33 , T. 20 S., R. 1 E. (fig. 14A). The core of the dome, north of an ancestral course of Willow Creek (G-3), consists of deformed beds of the Arapien Shale (fig. 12). Salt was once mined from these Arapien beds, and even now salt bloom mantles many of the Arapien mudstones. Green River strata overlie these Arapien mudstones along the margins of the dome, and in places, Crazy Hollow beds overlie the Green River strata.

About $3 \mathrm{~km}(2 \mathrm{mi})$ east of the dome the Green River beds dip westward toward the dome at angles of about $30^{\circ}$. At the east edge of the Arapien outcrop the westward-dipping Green River beds flex up sharply and dip eastward at about $30^{\circ}$. On the opposite side of the dome, at the west edge of the Arapien outcrop, Green River beds dip steeply $\left(60^{\circ}\right)$ northwestward. They are overlain by semiconsolidated sands and gravels, probably the Axtell Formation of Pliocene and (or) Pleistocene age, that dip northwestward at about $20^{\circ}$.

I interpret these exposures to mean that the Arapien Shale intruded and deformed this area twice. During the first intrusive event (late Eocene(?) or Oligocene(?)) the Green River was bowed up. Subsequently, these upturned beds were beveled and then buried by near-horizontal sand and gravel beds of the Axtell Formation. During the second intrusive event (Pliocene(?)-Pleistocene(?)) the Green River beds were bowed up once again to a still steeper angle, and the newly deposited, near-horizontal sand and gravel beds were tilted to an attitude considerably steeper than their former angle of repose. 

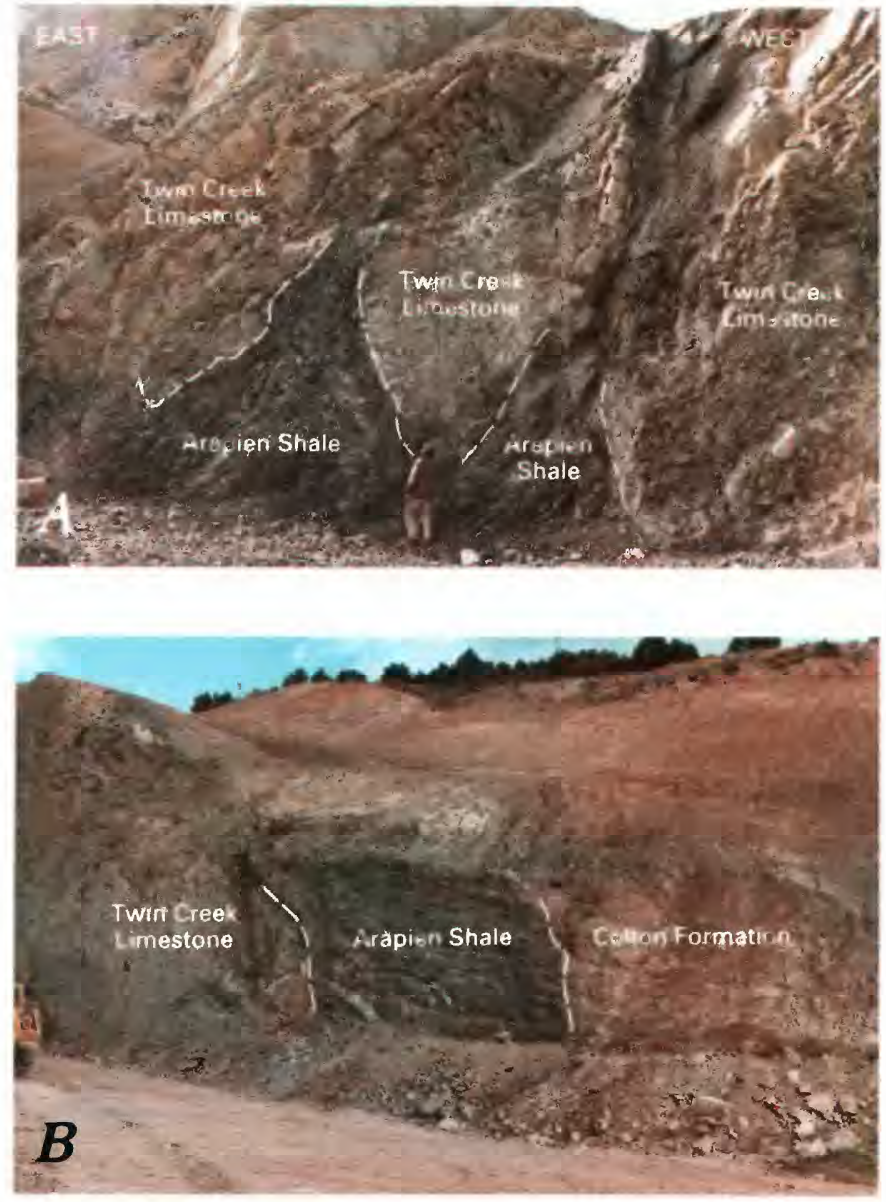

Figure 11.-Intrusive aspects of the Arapien Shale. Exposures are near Thistle, Utah. A, Beds of the Arapien Shale intrude and deform tilted beds of the Middle Jurassic Twin Creek Limestone, part of the erosional escarpment formed on the Charleston-Nebo thrust plate. $B$, View looking northward in roadcut where a segment of U.S. Highway 6 and 89, relocated following the Thistle landslide of April 1983, crosses the crest of "Billies Mountain." A dikelike mass of Arapien Shale is intruded between the Twin Creek Limestone (which here forms part of the erosional escarpment cut on the Charleston-Nebo thrust plate) and the Colton Formation, one unit in a mantle of younger Cretaceous and Tertiary rocks that partly overlies the thrust plate.

Elsewhere in this general area, an isolated outcrop of the semiconsolidated beds of sand and gravel (the Axtell Formation) has been warped into a syncline above an even more pronounced syncline in the Arapien (Gilliland, 1963, p. 121, and pl. 3, fig. 2). The evidence attests to the recency of the upward movement of the Arapien, and strongly suggests that similar movements have occurred repeatedly during the Tertiary and Quaternary.

\section{RED KNOLLS AREA}

At the three Red Knolls, along the west side of Sevier Valley near the small community of Redmond (G-3), the Arapien Shale appears to have intruded and bowed up the toe of an alluvial fan (fig. 13). The knolls coalesce to form a low ridge that trends about N. $30^{\circ} \mathrm{E}$. and that rises some 35 to $70 \mathrm{~m}(110$ to 230 $\mathrm{ft}$ ) above the adjacent ground surface. The ridge, which extends through parts of sec. 35 , T. 20 S., R. 1 W., and sec. 2, T. 21 S., R. 1 W., is underlain by soft reddish-brown mudstone and shaly siltstone of the Arapien Shale; the surrounding terrain by sand and gravel. The gravel is unusually rich in volcanic clasts, possibly derived from the Osiris Tuff (Willis, 1986). The volcanic clasts are so plentiful that the gravel has a gray to dark-gray hue; Gilliland (1948, p. 103), impressed by the volcanic detritus, referred to the gravels as the "volcanic gravels." These gravels are inclined away from the ridge.

Comparable volcanic clasts are widespread in the uplands near Salina (G-3), but are not found in the nearby Valley Mountains (G-2) west of the Red Knolls. Thus, it would seem that the volcanic-rich gravel deposits near Redmond may represent part of an old alluvial fan that spread northwestward from the Salina area. Since the development of the fan, erosion has removed the bulk of the fan, leaving only the remnant near Redmond. This remnant, which I view as the toe of the fan, is split into two parts by the northeast-trending ridge formed by the coalescence of the Red Knolls. One cannot help but be impressed by the contrast between the soft mudstones that form the Red Knolls, and the unconsolidated, lower, more durable sand and gravel deposits that flank them. It seems unreasonable to assume that these soft mudstone knolls could have remained high when more durable units were being eroded and removed. The knolls must have been elevated at some time in the recent past. This bifurcation of a former unified mass can only mean that at some time after the fan was formed, the Arapien Shale intruded the fan, bowed it up, and effectively split the toe of the fan into two parts. Since then, erosion has removed the former gravel cap from the knolls and now is rapidly lowering the knolls.

I am uncertain just when the Arapien intruded the fan. The sand and gravel mantle probably was formed during the Pleistocene; hence, a reasonable assumption is that the uplift began and ended during the late Pleistocene or early Holocene.

Others have also noted the intrusive nature of the Arapien Shale in the Redmond area, and they, too, 


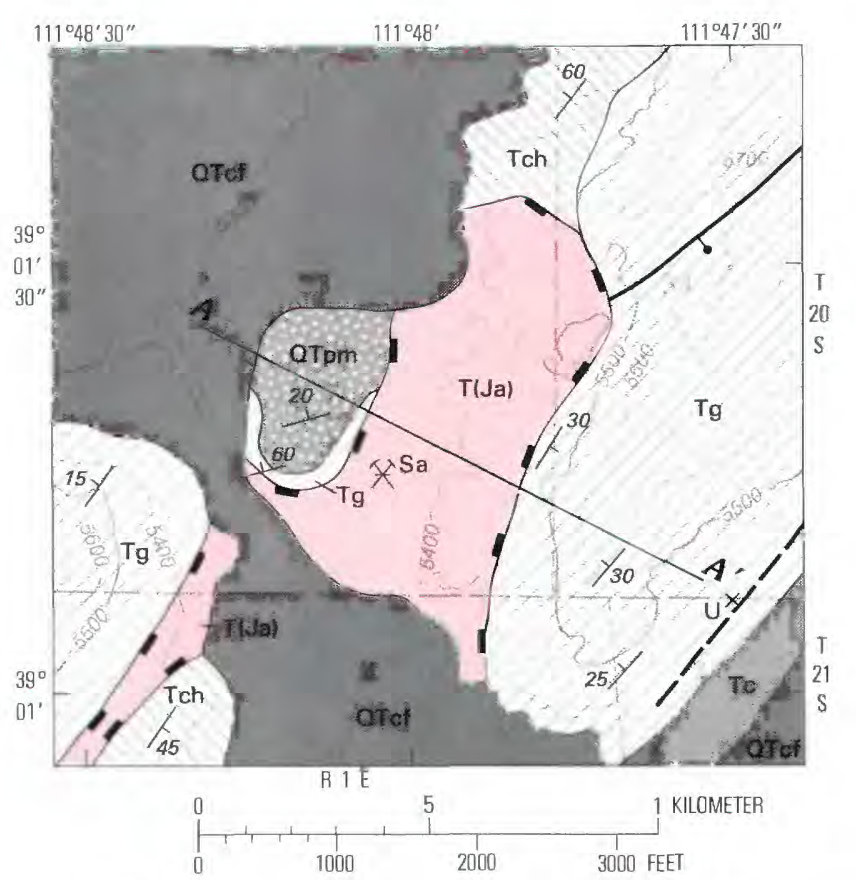

A

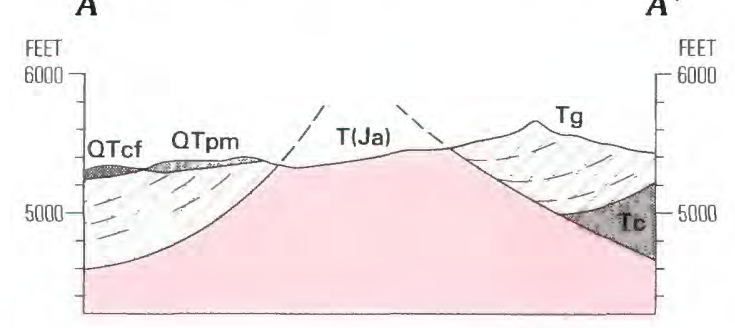

Figure 12.-Geology of an area near an ancestral course of Willow Creek, in which Arapien Shale mudstones ( $\mathrm{T}(\mathrm{Ja})$ ) have intruded and bowed up younger sedimentary rocks to form an elongate dome. Along east edge of area, Green River strata (Tg) dip westward, but farther west, at east edge of the intrusive mass, they flex up sharply, reverse dip, and dip eastward at angles of about $30^{\circ}$. Green River strata ( $\mathrm{Tg}$ ) that overlie west edge of intrusive mass (near center of map area) dip

\section{EXPLANATION}
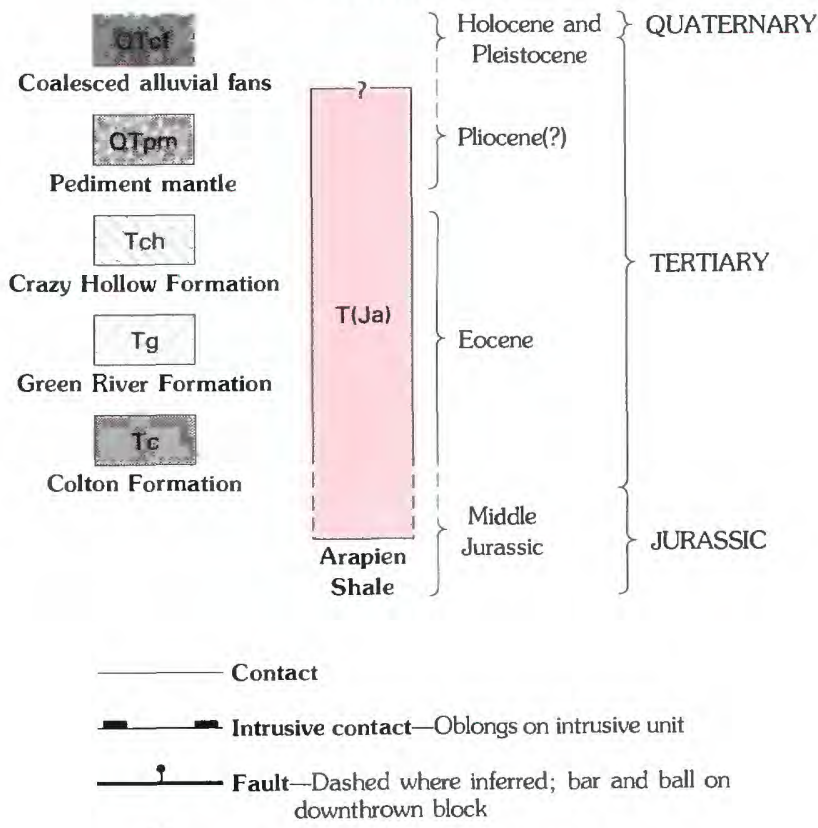

$\stackrel{25}{1}$ Strike and dip of inclined beds

$x^{\mathrm{Sa}}$ Abandoned salt mine

$x^{U} \quad$ Uranium prospect

northwestward at high angles. Semiconsolidated sands and gravels, here mapped as pediment mantle ( $Q T p m)$ but probably part of the Axtell Formation, overlie these steeply tilted Green River strata. These surficial deposits also dip northwestward at angles greater than their normal angle of repose. Fig. $14 \mathrm{~A}$ gives a photographic overview of the intrusive dome. Base modified from U.S. Geological Survey 1:24,000 Redmond (Utah), 1966. Topographic contour interval $100 \mathrm{ft}$.

attributed that movement to salt (Pratt, Heylmun, and Cohenour, 1966, p. 52; Picard, 1980, p. 145).

\section{CUESTA NORTH OF REDMOND}

A small north-trending cuesta that occupies the $\mathrm{SE} 1 / 4 \mathrm{SW} 1 / 4$ sec. 12 , T. 20 S., R. 1 W., just north of Redmond (G-3), illustrates still another example of the intrusive nature of the Arapien Shale. The cuesta is underlain by beds of the Green River(?) Formation. The strata dip eastward (valleyward) at about $35^{\circ}$, and rise above an even surface underlain by Arapien Shale mudstone and siltstone. A small mound, about $8 \mathrm{~m}(25 \mathrm{ft}) \mathrm{high}$, formed by the Arapien Shale, bulges above the ground surface and abuts the south end of the ridge (fig. 14B).

I interpret the cuesta as a remnant of the east flank of the Redmond diapiric fold. Presumably, the Green River(?) beds were bowed up by upward movement of the Arapien Shale, which in this area is part of the diapiric core of the fold. The Arapien mudstones in the small mound probably did not break through to the surface during this intrusive stage; if they had, they would have been removed long ago. More likely, in view of their soft and easily eroded nature, they broke through at some time-late Pleistocene or early Holocene-after the erosion surface that encircles the ridge was formed. 


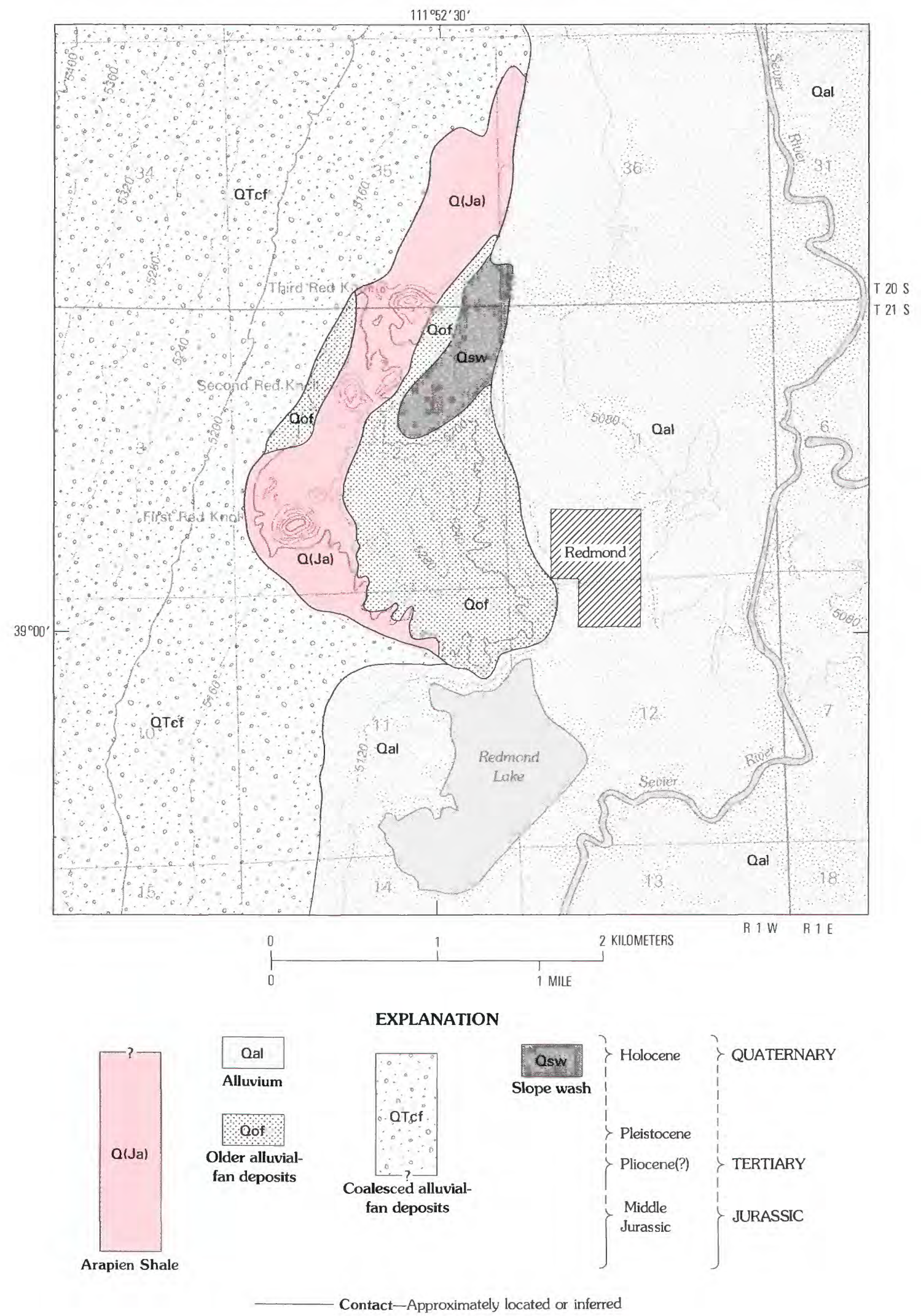


Figure 13 (facing page)_-Geology of the Red Knolls area near Redmond, Utah. Base modified from U.S. Geological Survey 1:24,000 Redmond Canyon and Redmond (1966). Contour interval $40 \mathrm{ft}$. Each of the Red Knolls is composed of red mudstones of the Arapien Shale ( $\mathrm{O}(\mathrm{Ja})$ ), and all are part of a northeast-trending ridge formed of the same material. The older alluvial-fan deposits (Qof) are rich in basaltic fragments not found in the Valley Mountains west of Redmond. Presence of these older fan deposits (Qof) on both sides of the northeast-trending Arapien ridge suggests that they were once a continuous deposit that has since been separated by the upthrust mass of the Arapien Shale.

NORTH

SOUTH
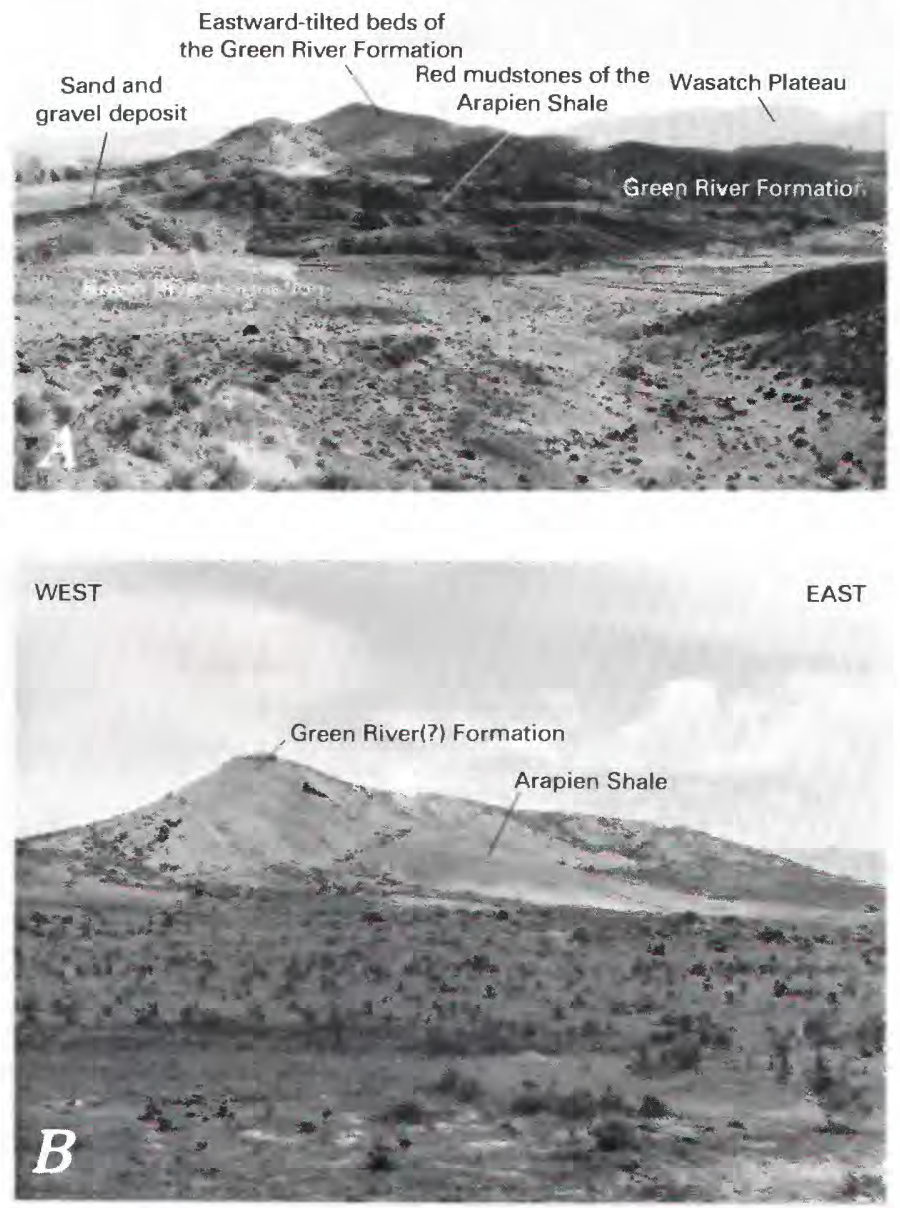

FIGURE 14.-Small-scale features throughout the Sanpete-Sevier Valley area that suggest intrusive movement by the Arapien Shale. A, Small intrusive dome near an ancestral course of Willow Creek. The red mudstones of the Arapien Shale have bowed up the overlying Green River strata to form an elongate, northeast-trending dome. See figure 12 for geologic map of area. $B$, Small mound composed of mudstones of the Arapien Shale that abut, deform, and probably intrude units of the Green River(?) Formation. Because the mudstones are soft and easily eroded, their presence in the mound suggests that they probably broke through to the surface only in late Pleistocene or even Holocene

\section{HOGBACKS IN EASTERN SEVIER VALLEY}

The moderately to steeply inclined beds that form the hogbacks in the eastern Sevier Valley (between Mayfield (F-3) and Salina (G-3)) also strongly imply upward movement of the Arapien Shale. The hogbacks consist of Green River beds unconformably overlying the Arapien Shale; the Green River beds, in turn, are conformably overlain by beds of the

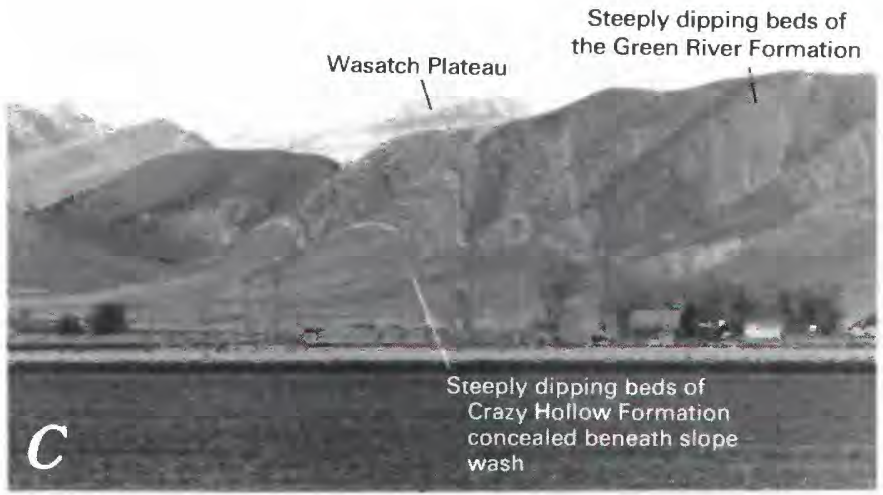

NORTH

SOUTH

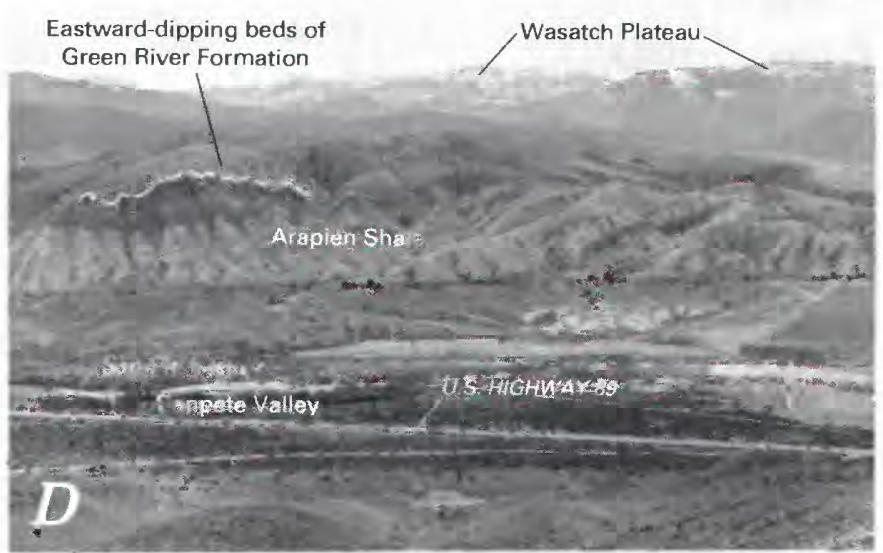

time. $C$, One of several large northeast-trending hogbacks north of Salina in which Green River beds, dipping steeply to the west and that form the back slope of the hogback, overlie Arapien mudstones (not shown). View is eastward. These relations have been interpreted by Billings (1933) to be the result of strip-thrusting. I suggest instead that they stem from the intrusive action of the Arapien mudstones that were forced upward by upwelling salt. $D$, View looking southeastward across Sanpete Valley at the face of a small knoll south of Ninemile Reservoir that displays upward tilting of the Green River Formation by the underlying Arapien Shale. See figure $\mathbf{1 5}$ for geologic map of area. 


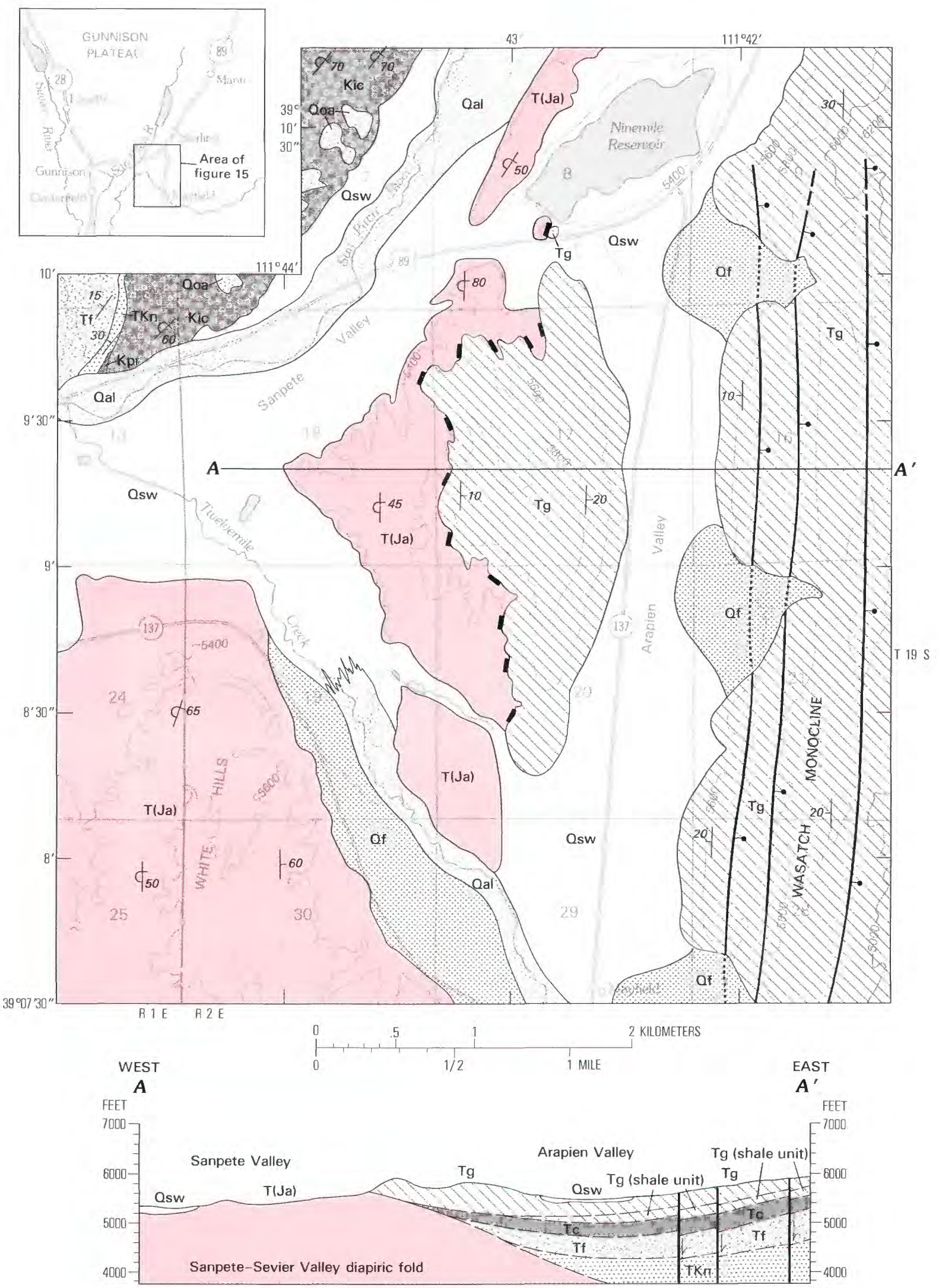



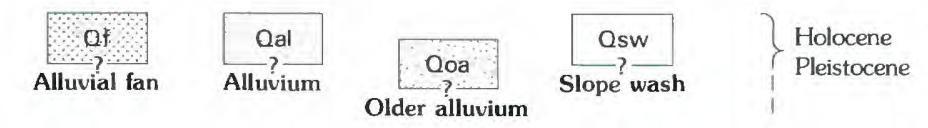

EXPLANATION

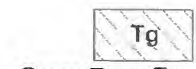

Green River Formation
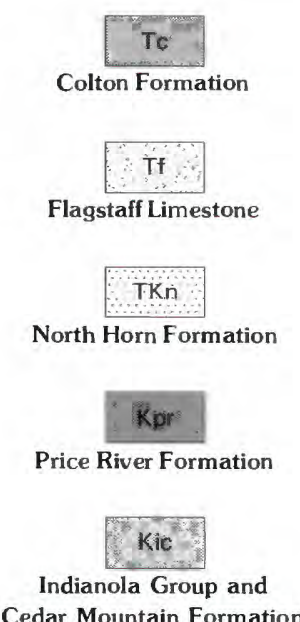

Cedar Mountain Formation

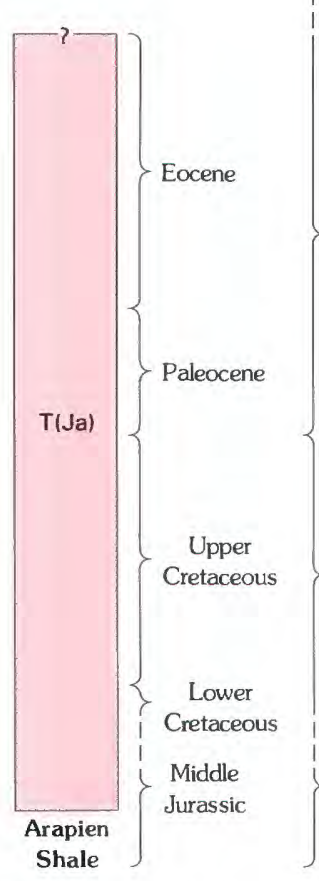

\}
1
\}
QUATERNARY

TERTIARY

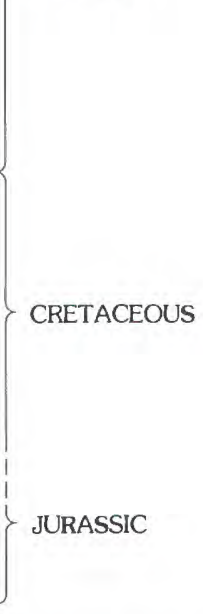

upward movement of the Arapien mudstones, which have been forced upward by the upwelling of the Sanpete-Sevier Valley salt diapir under Sanpete Valley. Base modified from U.S. Geological Survey 1:24,000 Sterling (1966). Contour interval $200 \mathrm{ft}$.

Figure 15 (above and facing page).-Geology of an isolated, unnamed hill directly south of Ninemile Reservoir. Strata of the Green River Formation ( $\mathrm{Tg}$ ) dip west as part of the Wasatch monocline. West of Arapien Valley the Green River directly overlies the Arapien Shale and dips east, reflecting

Crazy Hollow Formation of Eocene age. The Green River and younger beds dip westward at moderate to steep angles, and in a few places are near-vertical (fig. 14C). Commonly, the contact between the Green River and Arapien beds is even and regular, but locally it is ragged and irregular. In one or two places the Green River strata are broken to form an imbricate sheet, and here and there these strata dip into the contact at angles of $30^{\circ}$ to $60^{\circ}$ (Billings, 1933 , p. 153-154). Billings interpreted these relations to be the result of thrusting during which younger beds (the Green River and overlying strata) were shoved eastward along a preexisting unconformity onto older Jurassic shales (Arapien Shale). The term "strip-thrust" was coined by Billings to describe these thrust relations.

It is difficult to visualize, however, how the steep to vertical dip of these beds could have been formed solely by strip-thrusting. A more reasonable explanation, it seems to me, involves the bowing up and folding back of the Green River and younger strata by the upward movement of the Arapien Shale. Some support for this intrusive concept is given by the age relations. If the Green River Formation overlies the Arapien mudstones as a result of strip-thrusting, this thrusting must have begun at some time following deposition of the Crazy Hollow Formation of Eocene age, presumably during either the late Eocene, Oligocene, or later. This, however, raises vexatious problems. The thrusting that marks the Sevier orogeny began in either Late Jurassic (Armstrong, 1968) or Early Cretaceous (Heller and others, 1986) time, continued as episodic pulses throughout much of Cretaceous time, and seems to have ended during the Late Cretaceous or early Paleocene (Armstrong, 1968, p. 449). This lengthy episode of thrusting was followed by one of extensional tectonism that began during either the late Oligocene or 


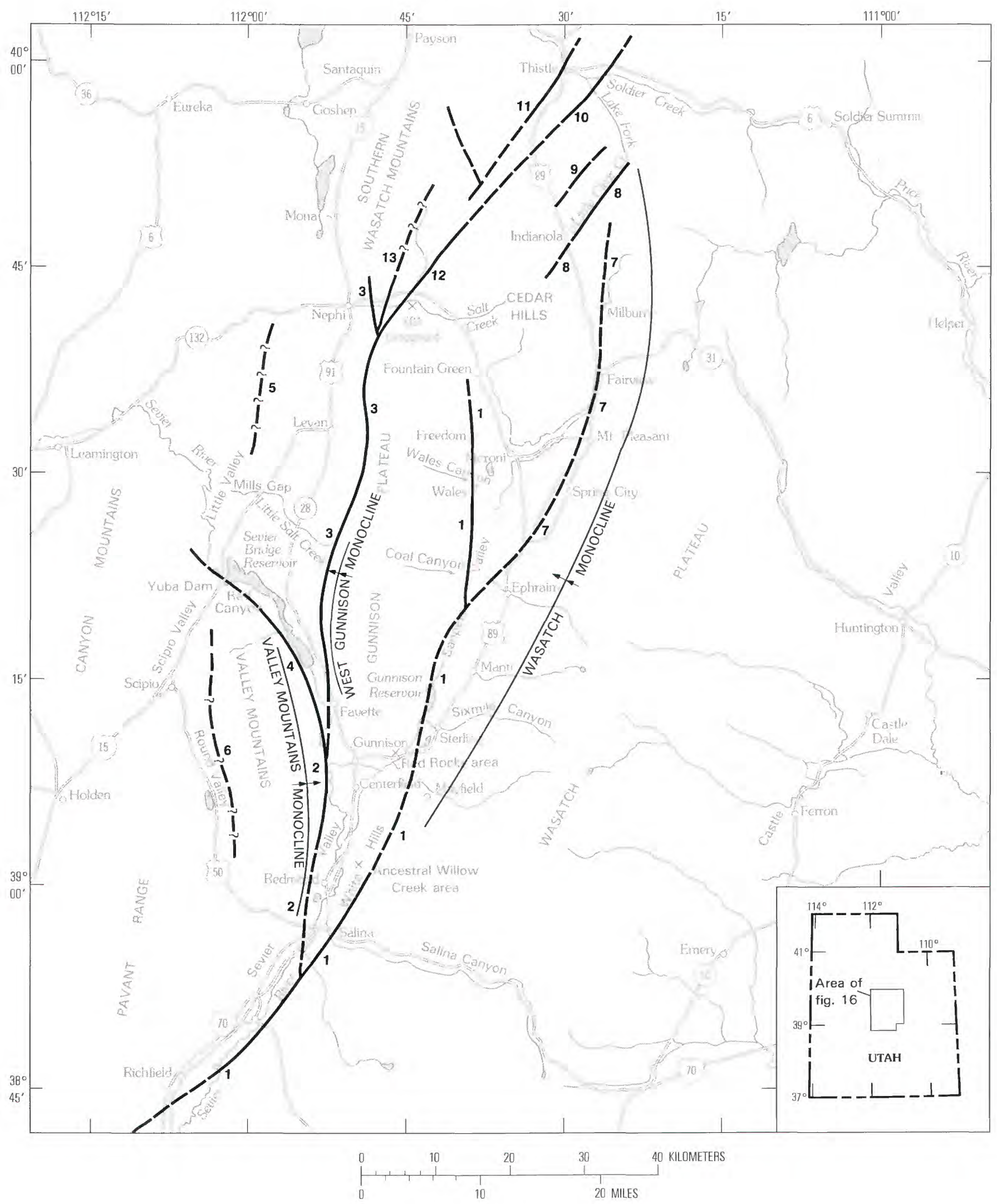


Miocene and that has persisted to the present. If strip thrusts were indeed formed during the Oligocene, or later, as Billings suggested for this sector of the Sevier Valley, this Tertiary thrusting would have begun long after thrusting ended elsewhere, and even as block faulting was beginning in this area in response to the widespread episode of crustal extension. The pattern of crustal deformation, so widespread throughout the Western Interior of the United States, argues against thrusting in this area after Paleocene time. In my view, the most plausible explanation for the structural deformation of these hogbacks involves the upward tilting of the Green River beds by the upward, rising movement of the Arapien Shale.

\section{SMALL HILL NEAR NINEMILE RESERVOIR}

A small hill directly south of Ninemile Reservoir (F-3) displays upward tilting of Green River beds by the Arapien Shale. Directly east of the hill, Green River limestone beds, dipping west as part of the Wasatch monocline, pass below the east edge of Arapien Valley (fig. 15). These Green River limestone beds reappear along the west side of the valley, but dip east, and thus form a small north-trending syncline whose axis has determined the trend of Arapien Valley. These limestone beds, part of the upper unit of the Green River Formation, directly overlie the Arapien Shale. The fact that units commonly found below these limestone beds, such as the shale unit that makes up the lower part of the Green River Formation, fail to crop out implies that these

FIGURE 16 (facing page)--Major diapiric folds in central Utah. Thick dark lines represent approximate position of fold crests; dashed lines represent inferred position. Query reflects uncertainty as to whether mapped structure is a diapiric fold. Encircled numbers identify folds. Page numbers refer to description of fold in text.

1 Sanpete-Sevier Valley diapiric fold (p. 38).

2 Redmond diapiric fold (p. 57).

3 Levan diapiric fold (p. 69).

4 Sevier Bridge Reservoir diapiric fold (p. 57).

5 West Hills diapiric(?) fold (p. 100).

6 Valley Mountains diapiric(?) fold (p. 101).

7 Fairview diapiric(?) fold (p. 98).

8 Little Clear Creek diapiric fold (p. 96).

9 Hjorth Canyon diapiric fold (p. 93).

10 Dry Hollow diapiric fold (p. 83).

11 Thistle Creek diapiric(?) fold (p. 83).

12 Pole Creek diapiric fold (p. 77).

13 Footes Canyon diapiric(?) fold (p. 81). older units pinched out against a rising paleo-highthe core of the Sanpete-Sevier Valley diapiric fold (cross section, fig. 15). The abrupt reversal of the Green River beds to an eastward dip must reflect the upward push of Arapien beds. The relations between the intrusive Arapien and the upward tilted Green River beds are well exposed along the west flank of the knoll (fig. 14D).

\section{MAJOR STRUCTURES (DIAPIRIC FOLDS)}

I recognize 13 diapiric folds in and adjacent to the Sanpete-Sevier Valley area (fig. 16), and believe that other comparable folds are still to be found. The folds appear as elongate, narrow, linear to faintly sinuous upwarps whose trend and extent reflect the underlying salt diapirs. The folds are much like the "salt anticlines" (salt-cored anticlines) of the Paradox Basin in southwestern Colorado and northeastern Utah (Cater, 1955, p. 125), and the "elongate salt structures" of northern Germany (Trusheim, 1960, fig. 3). Although the folds in central Utah have been deeply eroded, one is impressed by the similarities between the central Utah folds and those exposed in the Paradox Basin. These central Utah diapiric folds extend for tens of kilometers. In places, the position and trend of individual folds are expressed by outcrops of the calcareous mudstones of the Arapien Shale, which I interpret as the "diapiric core" of the fold (fig. 5). Elsewhere, the Arapien Shale is concealed beneath surficial deposits, and the fold is expressed by elongate, linear belts of steeply dipping to vertical and overturned sedimentary beds (the deformed country rocks of fig. 5). I interpret these complexly deformed sedimentary beds to be the eroded flanks of the fold. I believe that the strike of these vertical or overturned beds precisely reflects the trend of the diapiric fold and its underlying causative salt diapir.

The contorted beds of Arapien Shale that underlie the White Hills (G-3), along the east side of Sevier Valley, are an excellent example of the exposed core of a north-trending diapiric fold; the vertical to overturned beds that delineate much of the east flank of the Gunnison Plateau are an outstanding example of the eroded west flank of the same north-trending fold-the Sanpete-Sevier Valley diapiric fold.

These vertical to overturned beds of the deformed country rock (fig. 5) are typically confined to a narrow zone. In place after place, these beds, traced perpendicular to strike, abruptly lessen in dip away 
from the diapiric core and conform to the regional dip in distances as short as several kilometers. If these steeply tilted beds were concealed beneath surficial deposits, it would be almost impossible from surface exposures to recognize the presence of one of these folds (fig. 64).

The 13 diapiric folds trend generally northward through the Sanpete-Sevier Valley area (fig. 16), more or less parallel to the many grabens and highangle normal faults that break the crest of the Wasatch Plateau. Most of the folds trend northeast; a few-mainly those that flank the Gunnison Plateautrend north; a single fold, the Sevier Bridge Reservoir fold, trends northwest. Their spatial distribution suggests that most are interrelated, each branching off another much as distributary streams branch off a master stream.

The Sanpete-Sevier Valley fold (fig. 16, 1) appears to be the master fold. Branching off its south end is the Redmond fold (2), which extends at least from Redmond (possibly Sigurd) to near Gunnison and may continue northward to join the Levan fold (3). Near Fayette, the Sevier Bridge Reservoir fold (4) may branch off the Redmond fold. The West Hills fold (5), trending north, has been drilled and much salt found in its core. The Valley Mountains fold (6) also may once have had a salt core; recent drilling failed to penetrate any salt. A north-trending graben in the Valley Mountains, Japanese Valley, suggests that the salt core of the fold may have been dissolved and removed, with subsequent collapse of the overlying strata to form the graben. The Fairview diapiric(?) fold (7) may branch off the master Sanpete-Sevier Valley fold near Ephraim and extend northeastward to near Indianola. The Little Clear Creek fold (8) trends northeastward; its crest has determined the position of Little Clear Creek. The northeast end of the Little Clear Creek fold passes directly into the Dairy Fork graben, implying dissolution of the salt core with subsequent collapse of the overlying beds to form a graben. The Hjorth Canyon fold (9) appears as an elongate northeast-trending dome. The Dry Hollow fold (10) is collinear with and may be the north end of the northeast-trending Pole Creek fold (12). The Thistle Creek fold (11) and the Footes Canyon fold (13) seemingly have deformed part of the Charleston-Nebo thrust plate.

\section{SANPETE-SEVIER VALLEY DIAPIRIC FOLD}

The Sanpete-Sevier Valley diapiric fold (the Sanpete-Sevier Valley anticline of Gilliland (1963)) appears to be the longest of the 13 folds so far recognized (fig. 16, 1). On the basis of diverse geologic evidence (such as exposures of the Arapien Shale, steeply tilted to overturned sedimentary beds, testwell data, and collapse phenomena), I believe that the fold extends northward from near Richfield (I-1) to at least Moroni (D-4). Gravity data (fig. 52) imply that the fold extends northward beyond Moroni, possibly reaching Fountain Green (C-4). If so, the fold has a minimum length of at least $95 \mathrm{~km}(60 \mathrm{mi})$, and may be as much as $125 \mathrm{~km}$ (75 mi) long. In general, the fold trends about N. $30^{\circ} \mathrm{E}$., although its course is faintly sinuous.

The exposed diapiric core of the fold, expressed as an unbroken belt of Arapien mudstone, extends from near Richfield on the south to near Manti (E-4) (fig. 8). Northward, beyond Manti, the core is completely concealed beneath the surficial deposits that floor Sanpete Valley. Between Richfield and Salina (G-3), the core clings to the east side of Sevier Valley, where volcanic flows mantle both flanks. Those volcanic rocks along the east flank of the core dip eastward; those along the west flank dip westward. Locally, these volcanic rocks are overturned (Gilliland, 1963, p. 121). Farther north, between Salina and Mayfield (F-3), the core of the fold still hugs the east side of Sevier Valley, but here the core's west flank is overlain by Green River strata that dip moderately to steeply westward. The core's east flank, presumably eroded, is concealed beneath the surficial deposits that floor Arapien Valley (G-3). Near Sterling (F-4), the core fills the narrow mouth of Sanpete Valley; both flanks of the fold are exposed as near-vertical to overturned beds of Cretaceous rocks (figs. 19 and 21).

The vertical to overturned Indianola beds along the east flank of the Gunnison Plateau (D-3) represent the partly eroded west flank of the fold (fig. 17). These strata are unconformably overlain either by the Price River Formation, or, where Price River strata pinch out presumably against the flanks of the fold, by the North Horn Formation. Invariably, these younger Price River and North Horn strata dip away from the crestal part of the fold at moderate angles $\left(20^{\circ}\right.$ to $\left.30^{\circ}\right)$. In the Sterling area, where both flanks of the fold are exposed, Indianola beds east of the core are overlain by North Horn strata that dip east $20^{\circ}$ to $30^{\circ}$. West of the core, North Horn strata dip west at comparable angles.

I believe that the Sanpete-Sevier Valley diapiric fold abuts the east side of the Gunnison Plateau as far north as Freedom (D-4); beyond Freedom the crestal part of the fold trends northward toward Fountain Green (C-4), even as the front of the Gunnison Plateau bends to the northwest. In this sector, thus, the crest of the fold may be about $2.5 \mathrm{~km}(1.5 \mathrm{mi})$ east of the steep slopes and cliffs that mark this part of the plateau front. I suspect that the fold curves near 

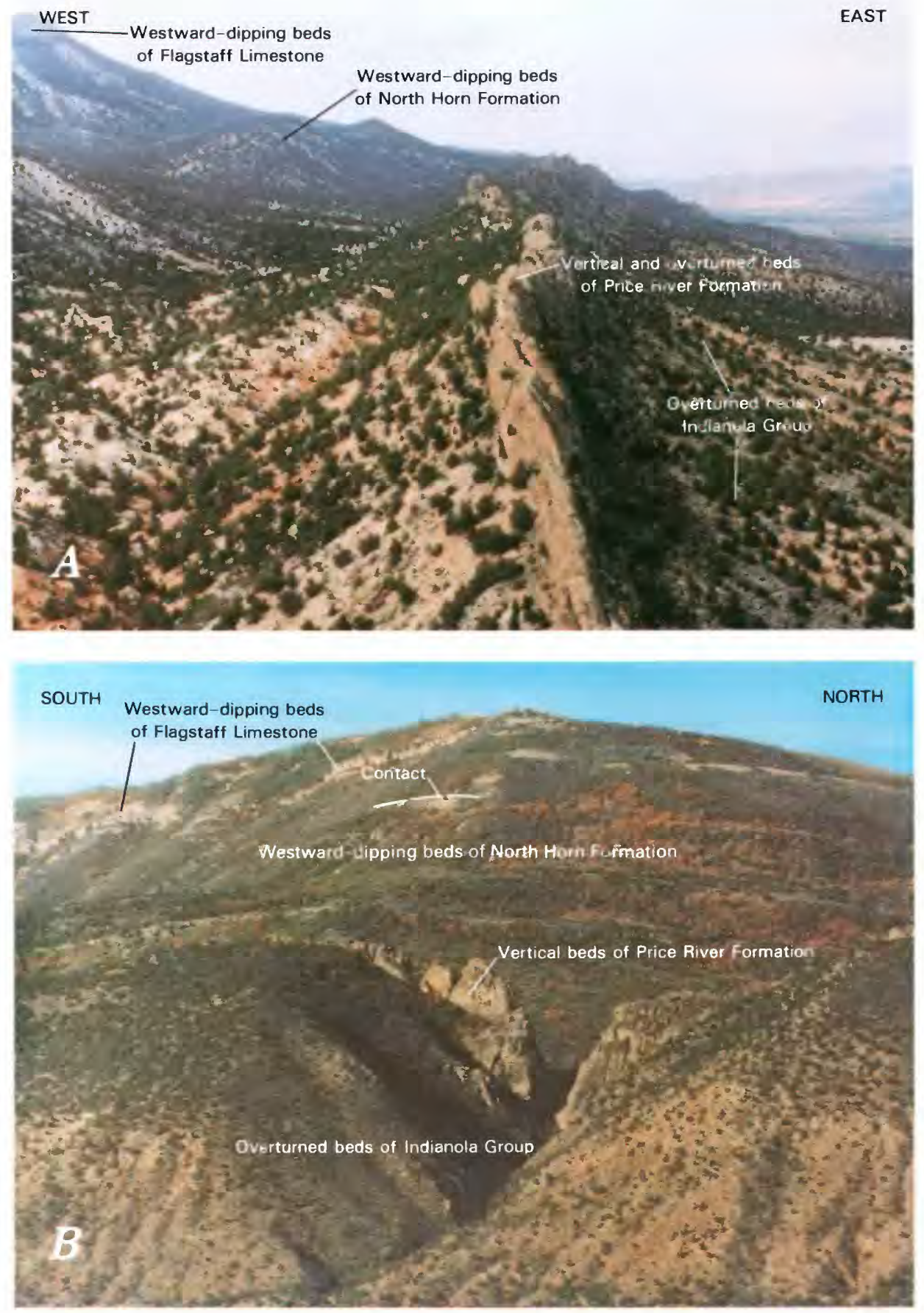

Figure 17.-Aerial views along east flank of Gunnison Plateau. Vertical to overturned beds of the Indianola Group and Price River Formation form a striking reef along part of the plateau's east front. In most places, gently to moderately inclined Price River strata unconformably overlie vertical and overturned beds of the Indianola Group. $A$, In the view shown here (looking northward), the Price River beds, along with the underlying Indianola strata, have been tilted upward to vertical and overturned attitudes. These vertical and overturned beds flatten westward and underlie the westward-dipping, reddish-brown mudstones and brown sandstone beds of the North Horn Formation, which form the steep escarpment. The North Horn Formation, in turn, is overlain conformably by westwarddipping beds of the Flagstaff Limestone. $B$, View looking westward, showing reef formed by vertical and overturned beds of the Price River and Indianola Group (center of photograph), and still farther west, the westward-dipping North Horn strata conformably overlain by the Flagstaff Limestone (on horizon). See cross section $A-A^{\prime}$, figure 24, for details. Photographs by D.A. Sprinkel, Placid Oil Company. 

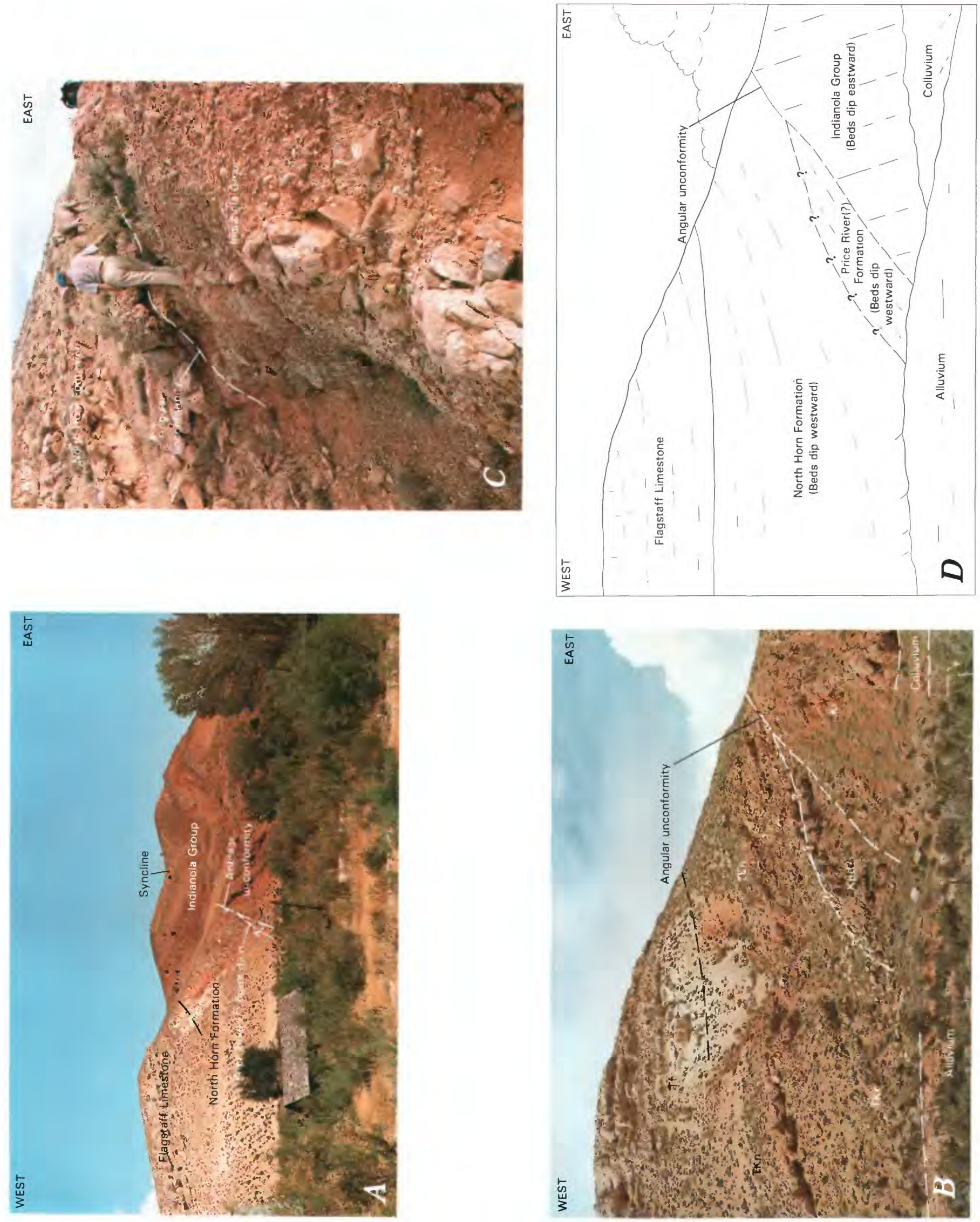
Fountain Green and trends northwestward, conforming to the trend of the west fork of Sanpete Valley.

In my view, the $620 \mathrm{~m}(2,038 \mathrm{ft})$ of salt and interlayered subordinate mudstone penetrated by the Price "N" well (fig. 9), which was about $2.8 \mathrm{~km}$ (1.7 mi) east of the Gunnison Plateau front, reflects the east flank of the causative salt diapir. Had the well been drilled farther to the west, in essence, closer to the plateau front, I believe that thicker deposits of salt would have been found. The Hanson Oil Company's Moroni wells, drilled about $5 \mathrm{~km}$ ( $3 \mathrm{mi}$ ) east of the Price "N" well, penetrated great thicknesses of Arapien mudstone, but found no salt. Seemingly, the Moroni wells are substantially east of and beyond the flanks of the salt diapir.

Unusual geologic and structural relations at four discrete localities along the flanks of the fold demonstrate how this fold repeatedly grew and collapsed. These localities are: (1) the Red Rocks (F-3)-Sixmile Canyon area (F-3), (2) Wales Gap (D-4), (3) the ancestral Willow Creek area (also known as the Willow Creek gap), and (4) the Gunnison Reservoir (F-3) area. For each area, I discuss the salient features and propose a sequence of diapiric events to explain the present configuration of the strata.

RED ROCKS-SIXMIIE CANYON AREA

The Red Rocks (Christianburg) and Sixmile Canyon areas represent the west and east flanks, respectively, of the Sanpete-Sevier Valley fold. In these two areas the exposed rocks demonstrate not only depositional thinning but also how diapiric folds grew and collapsed.

FIGURE 18 (facing page).-Red Rocks area, north of U.S. Highway 89, between Gunnison ( $\mathrm{F}-3)$ and Sterling $(\mathrm{F}-4)$. A, Distant view, looking north at the Red Rocks area. As the open syncline (along skyline), in conglomerate beds of the Indianola Group, is traced southward (toward camera), the syncline closes to become an isoclinal fold whose axial plane dips steeply eastward. The eastward-dipping conglomerate ledges (slightly to right of center) are part of the west flank of that fold. These conglomerate beds are overlain with striking angular unconformity by both Price River and North Horn strata. B, Close-up view of Red Rocks exposure showing unconformable relations between eastward-dipping beds of the Indianola Group (right side of photo), and westward-dipping beds of the Price River and North Horn Formations. $C$, Detailed view of angular unconformity between Indianola Group and the overlying North Horn strata. Geologist stands on eastward-dipping Indianola strata; dog stands on westward-dipping North Horn. $D$, Sketch illustrating details of photograph shown in $B$.
Rtio Rocks ARta

The southeast end of the Gunnison Plateau, north of U.S. Highway 89 between Gunnison $(\mathrm{F}-3)$ and Sterling (F-4), is known locally as the "Red Rocks area" because of the well-exposed reddish conglomerate beds that here make up the undivided Indianola Group (fig. 18A, and fig. 19). Spieker (1949, p. 76) referred to the site as the Christianburg area; I have not used that name because Christianburg is not on modern highway maps. The critical exposures occupy parts of secs. 12 and 13, T. 19 S., R. 1 E., and sec. 7, T. 19 S., R. 2 E.

Among the oldest units exposed in the Red Rocks area are the steeply inclined and overturned, coarse conglomerate beds of the Indianola Group (fig. 18A, $B$ ). These beds dip eastward, and are flexed to form an isoclinal syncline whose axial plane dips steeply to the east. An angular unconformity that dips about $25^{\circ} \mathrm{W}$. (fig. $18 A-D$ ) truncates the conglomerates, and an unusually thin section of the Price River Formation ( 0.5 to $1.5 \mathrm{~m}$ ( 2 to $5 \mathrm{ft}$ ) thick) overlies the unconformity. The Price River is, in turn, conformably overlain by about $40 \mathrm{~m}(135 \mathrm{ft})$ of North Horn strata. The Price River and North Horn sequence dips northwestward at about $30^{\circ}$. The North Horn strata are overlain by beds of the Flagstaff Limestone, which also dip northwest at about $30^{\circ}$. These limestone beds belong to a zone in the Flagstaff Limestone that is "some distance above the North Horn" (Spieker, 1949, p. 76). Thus, the structural relations between the North Horn and Flagstaff are uncertain. Spieker (1949, p. 76), referring to these relations, commented: "The question is whether or not there is an angular relation at the contact between the Flagstaff and North Horn formations, and it is not settled. The contact is concealed***." I suspect that an unconformity separates the North Horn beds from the Flagstaff, and that this unconformity, too, is tilted northwestward.

In gross aspect, then, the exposed sequence is broken by an angular unconformity between the Indianola beds and the Price River and North Horn sequence, and a disconformity(?) between North Horn and Flagstaff strata.

All units exposed in the Red Rocks area, from the Price River to the Flagstaff, are anomalously thin compared with their thicknesses some $13 \mathrm{~km}(8 \mathrm{mi})$ to the east along the flanks and crest of the Wasatch Plateau.

Figure 20, which schematically depicts the west limb of the Sanpete-Sevier Valley fold, illustrates the sequence of events that I believe led to the present 


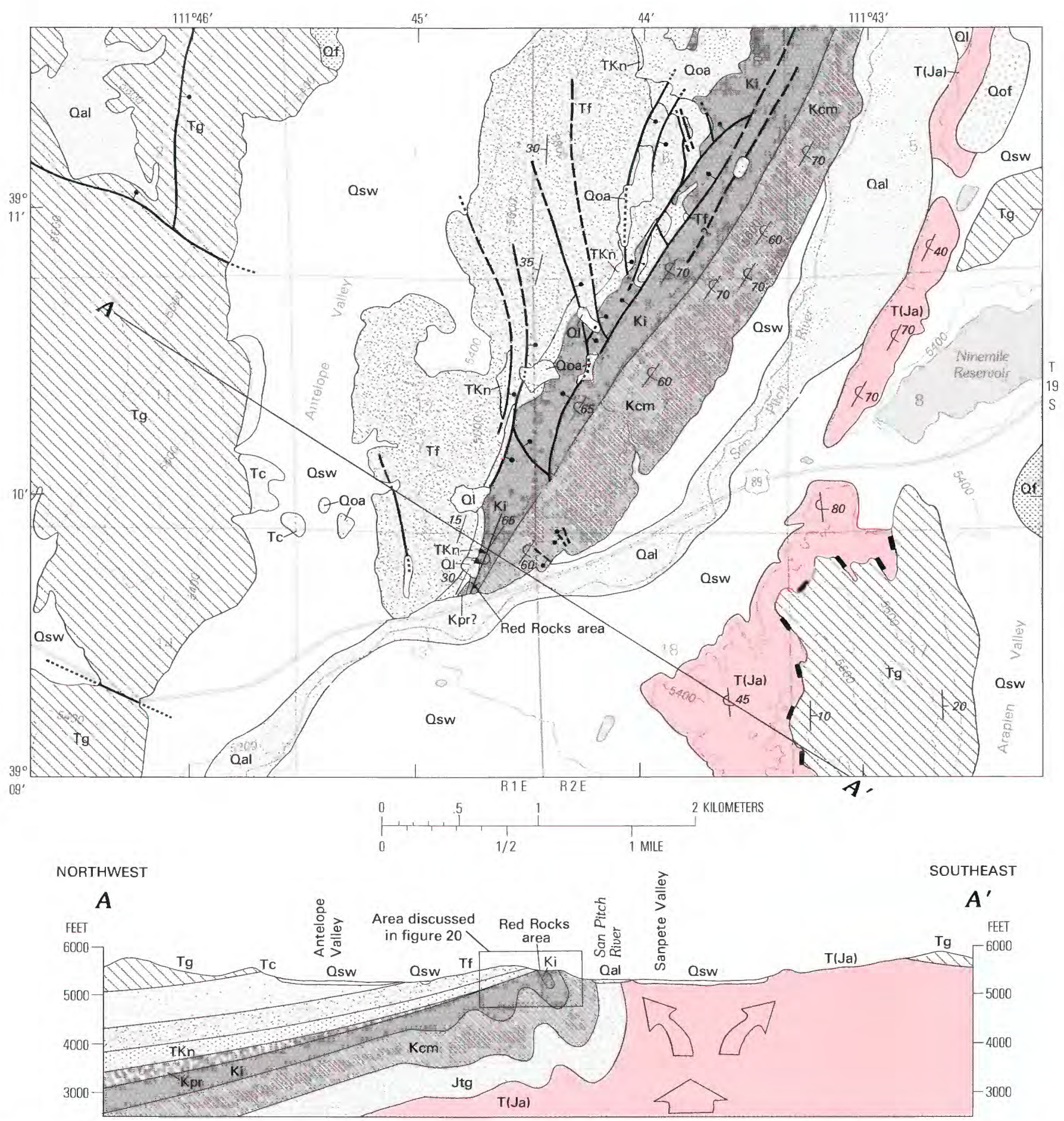

FIGURE 19 (above and facing page).-Geology of Red Rocks area (F-3). Strata represent part of the west flank of the Sanpete-Sevier Valley diapiric fold. Base modified from U.S. Geological Survey 1:24,000 Sterling and Gunnison (1966). Contour interval $200 \mathrm{ft}$.

geologic relations; the following discussion is keyed to that figure.

The isoclinal fold in the Indianola conglomerates (fig. 20, I) suggests that major movement of the Sanpete-Sevier Valley diapir first occurred after consolidation of the Indianola, probably during Late Cretaceous (Campanian?) time. The Indianola beds were bowed up and then steeply tilted or overturned as the diapiric fold developed. Probably, Indianola strata on both sides of the fold were overturned 


\section{EXPLANATION}
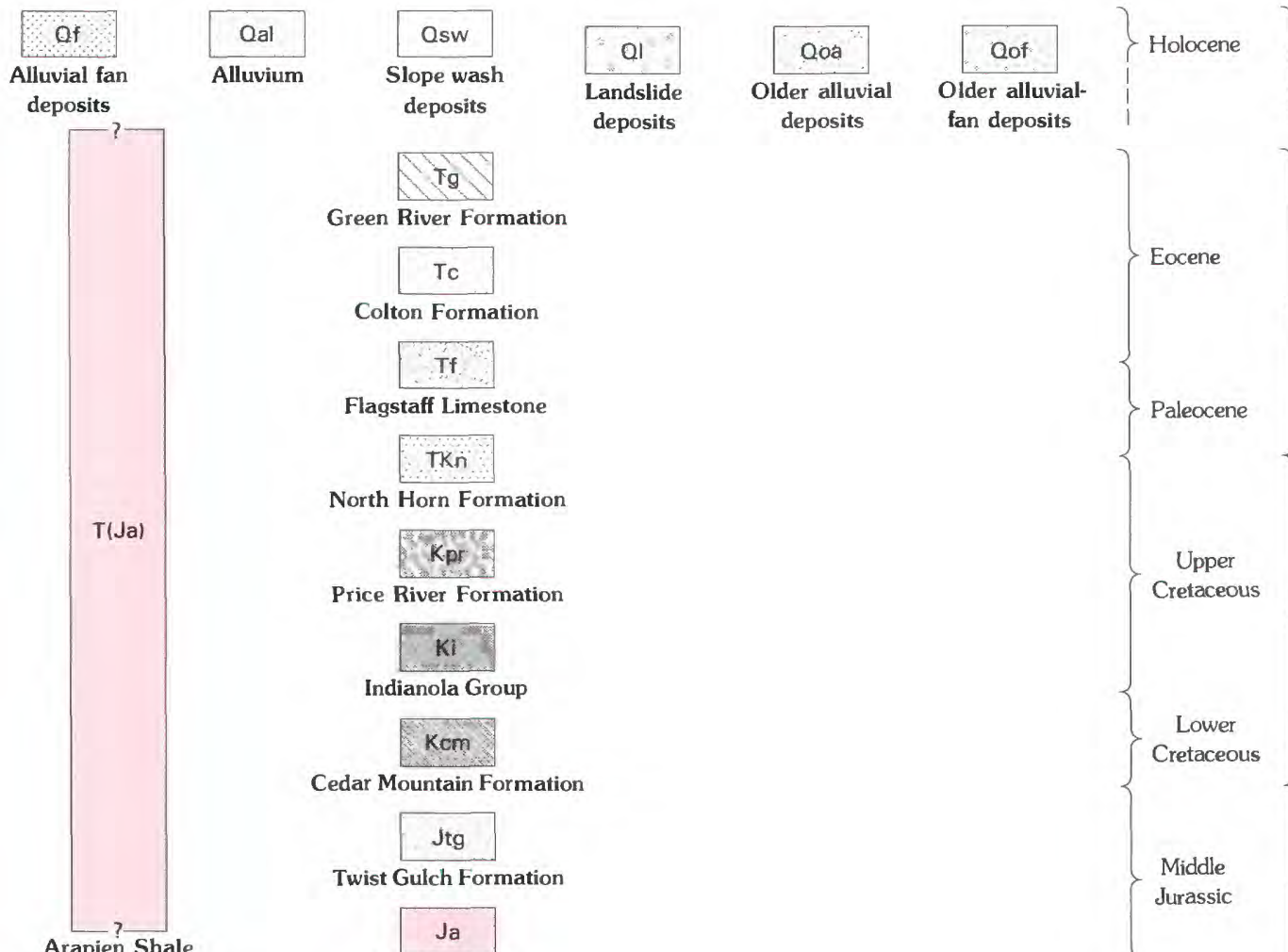

QUATERNARY

Green River Formation

$$
\text { Tc }
$$

Colton Formation

$$
\begin{gathered}
\text { Tf } \\
\text { Flagstaff Limestone } \\
\text { TKn }
\end{gathered}
$$

North Horn Formation

$$
\mathrm{K} p \mathrm{pr} \text { : }
$$

Price River Formation

$$
\begin{gathered}
\mathrm{Ki} \\
\text { Indianola Group } \\
\mathrm{Kcm}
\end{gathered}
$$

Cedar Mountain Formation

$$
\begin{gathered}
\text { Jtg } \\
\text { Twist Gulch Formation } \\
\mathrm{Ja} \\
\text { Arapien Shale }
\end{gathered}
$$
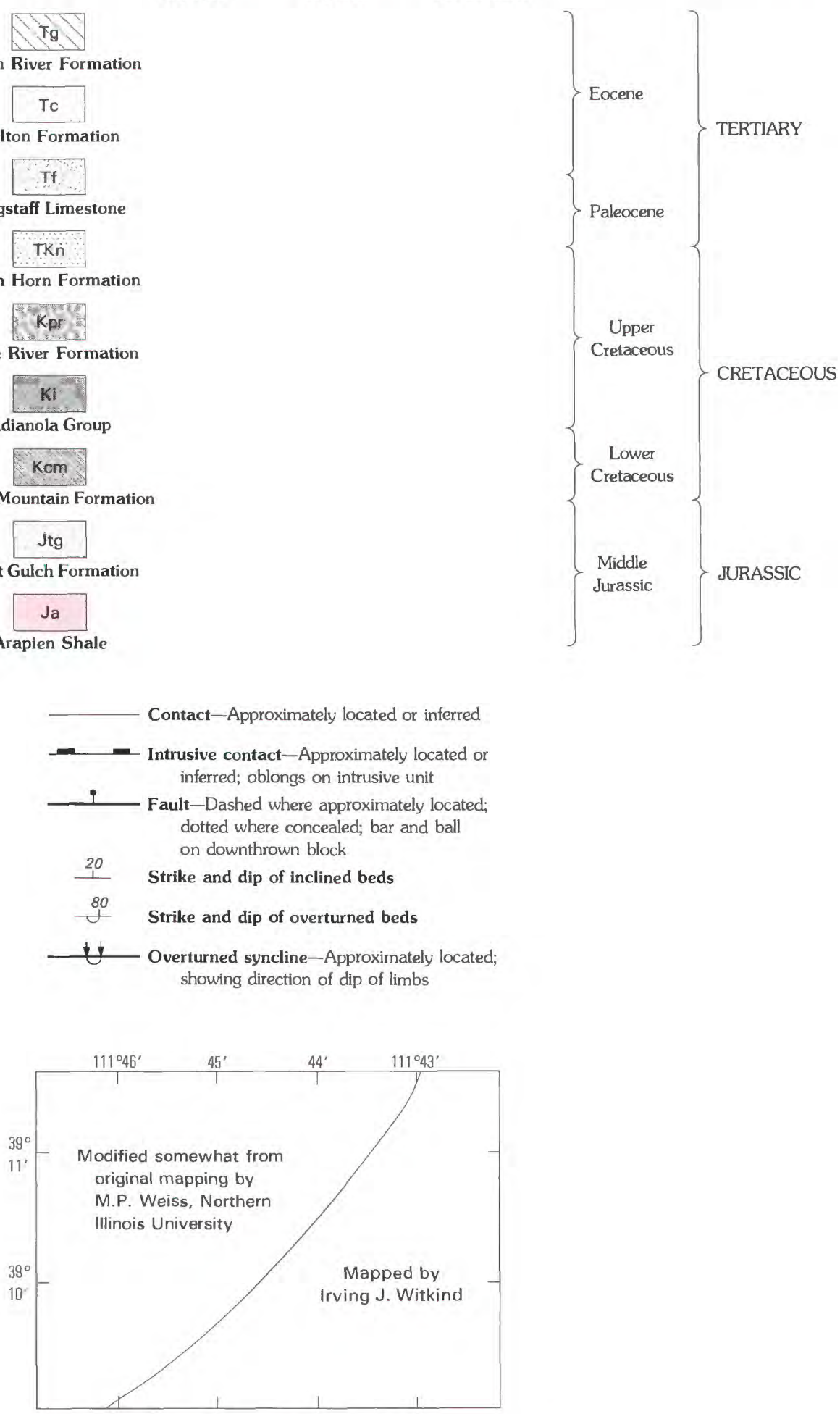

SOURCES OF GEOLOGIC DATA 

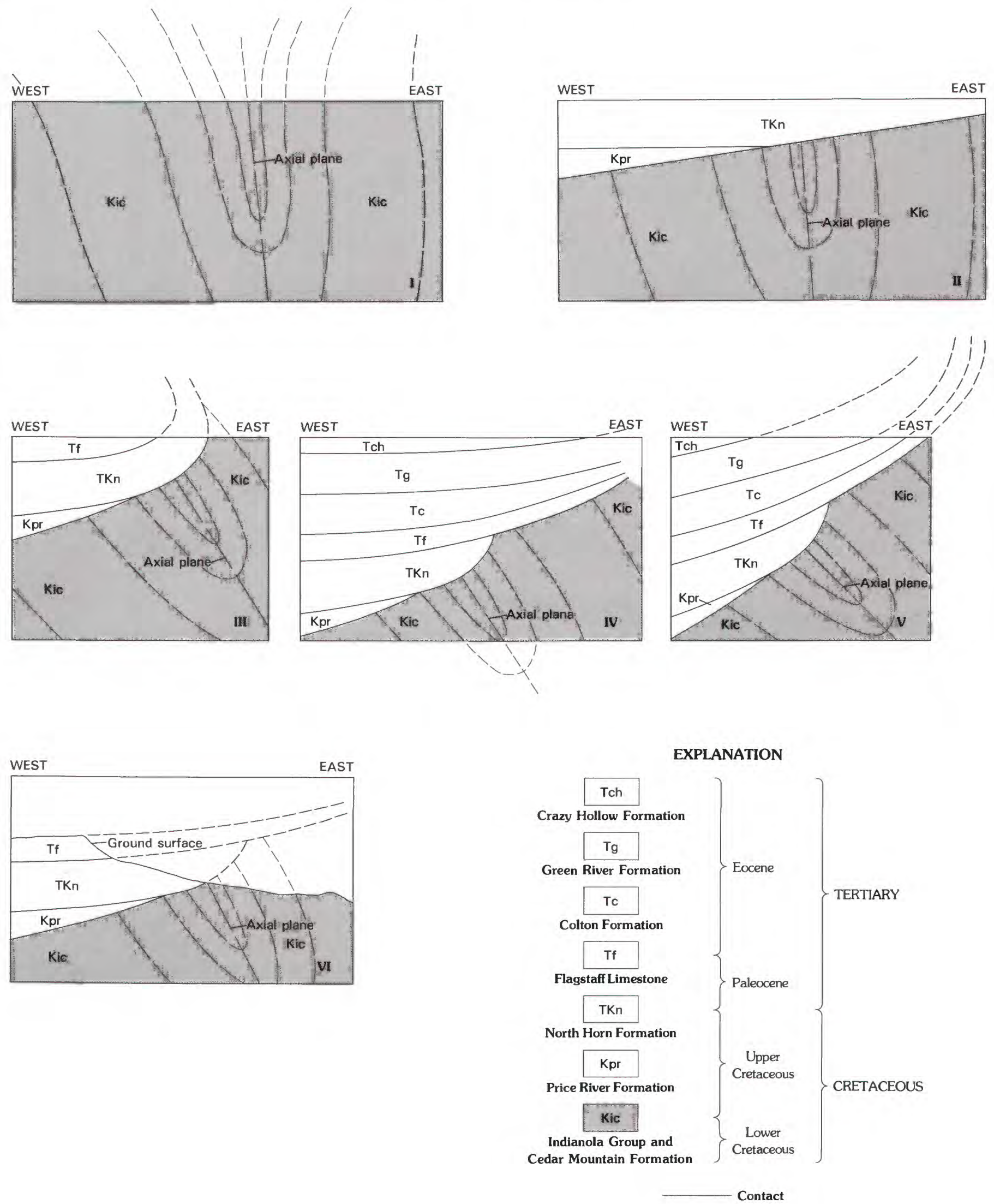
FiguRE 20 (facing page).-Diagrammatic cross sections suggesting how the Red Rocks area evolved. All sketches depict part of the west flank of the Sanpete-Sevier Valley diapiric fold. Ground surface in $\mathrm{I}-\mathrm{V}$ speculative, not shown.

I. At some time during the Late Cretaceous (Campanian?), beds of the Indianola Group and the underlying Cedar Mountain Formation (Kic) were folded and locally overturned as a result of upward movement of the Sanpete-Sevier Valley salt diapir. A small isoclinal syncline, whose axial plane dips steeply eastward, was formed in the Red Rocks area.

II. As rate of upward movement decreased, erosion cut a surface of low relief across the diapiric fold. Price River strata (Kpr), deposited on this surface, thin eastward (toward the diapir) and locally pinch out, reflecting the diapir's slow persistent upward movement. North Horn strata (TKn), deposited conformably on the Price River (Kpr), also thin eastward; both North Horn and Price River were warped upward in response to the slowly rising diapir.

III. A renewed upward surge of the salt diapir warped up and deformed the Price River (Kpr) and North Horn (TKn) sequence, and Flagstaff Limestone (Tf) deposited above. Underlying Indianola and older strata $(\mathrm{Kic})$ were tilted to more recumbent positions.

IV. Again a surface of low relief was cut across the fold; this time, however, the surface beveled both the Price River (Kpr) and North Horn (TKn) sequence and some of the underlying Indianola and Cedar Mountain strata (Kic). Flagstaff sediments (Tf), deposited on this surface, thin eastward and were warped up in response to the slow, persistent upward movement of the diapir. Younger sediments (Colton (Tc), Green River ( $\mathrm{Tg}$ ), and probably Crazy Hollow (Tch)) also thin eastward and also were warped by movement of the diapir.

V. As in the Sixmile Creek canyon area to the east, two alternatives can explain what occurred next. The first suggests that the newly deposited Tertiary strata (Flagstaff to Crazy Hollow strata) were warped up to form a diapiric fold by a renewed upward surge of the diapir. A second alternative is that the newly deposited strata subsided, presumably as a result of removal of salt, to form the eastward-facing East Gunnison monocline that has since been destroyed by erosion.

For the Red Rocks area, as for the Sixmile Creek canyon area to the east (fig. 22), the first alternative would seem to be correct, based on the vertical attitudes of the Flagstaff and younger strata in the ancestral Willow Creek area, just some $11 \mathrm{~km}$ (7 mi) south of the Red Rocks area.

After this new fold was destroyed and much of the underlying salt was removed, the upwarped strata subsided to form the eastward-facing East Gunnison monocline.

VI. Erosion has since destroyed the monocline, removed much of the younger sedimentary cover, and exposed part of the intensely folded underlying Indianola and older strata (Kic). Compare this illustration with the photographs and sketch of figure 18 and with that part of the cross section indicated in figure 19.

during this intrusive stage: those in the Red Rocks area were overturned to the west (and so dipping east), those in the Sixmile Canyon area were overturned to the east (and so dipping west).

I suspect that the fold failed shortly after it was formed and the remnants then quickly eroded.
Erosion beveled the tilted beds to a broad surface of low relief. As Price River strata unconformably overlie this erosional surface, the surface must have been formed during the Late Cretaceous, presumably during middle Campanian time, assuming that Price River beds are correctly dated as late Campanian (Fouch and others, 1982, chart, p. 270-271).

Even as Price River sediments were spread across this erosion surface, the slow, imperceptible upwelling of the diapir gradually arched the surface, effectively restricting deposition of these sediments. In places, Price River sediments pinched out against this rising barrier (fig. 20, II). In time, North Horn sediments were deposited, conformably overlying Price River units. As North Horn strata also thin in this general area, I assume that the slow, continuous upwelling of the salt persisted into North Horn time. In central Utah the North Horn ranges in age from Late Cretaceous (Maastrichtian) to Paleocene, possibly early Eocene (Fouch and others, 1982, chart, p. 270-271), so deposition must have continued uninterrupted during this interval.

Reactivation of the salt diapir during the Paleocene resulted in a new daughter fold that appears to have occupied the same site and had the same trend as the earlier parent fold. The recently deposited Price River and North Horn sequence was bowed up to form a fan-shaped diapiric fold (fig. 20, III), even as the older, underlying Indianola strata were tilted to still steeper angles. Again the fold failed, presumably as a result of renewed removal of salt from the underlying causative salt diapir. The fold partially collapsed; its remnants were then once again quickly eroded to form a surface of low relief-one, however, that truncated both the upturned Price River and North Horn sequence as well the near-vertical Indianola strata. Even as sediments of the Flagstaff Limestone began to be deposited upon this newly formed erosion surface, the persistent slow upwelling of the salt forced up the crestal part of the fold, and the lower and medial parts of the Flagstaff Limestone wedged out against this rising barrier. The younger (upper) parts of the Flagstaff extended across the crest of the fold, but they, too, were greatly attenuated by the rising fold. In time, still younger sediments (now represented by the Colton and Green River Formations) were deposited. The anomalous thinness of these units near the crestal part of the diapir suggests that the salt continued its persistent upward movement even as these units were being formed (fig. 20, IV). 

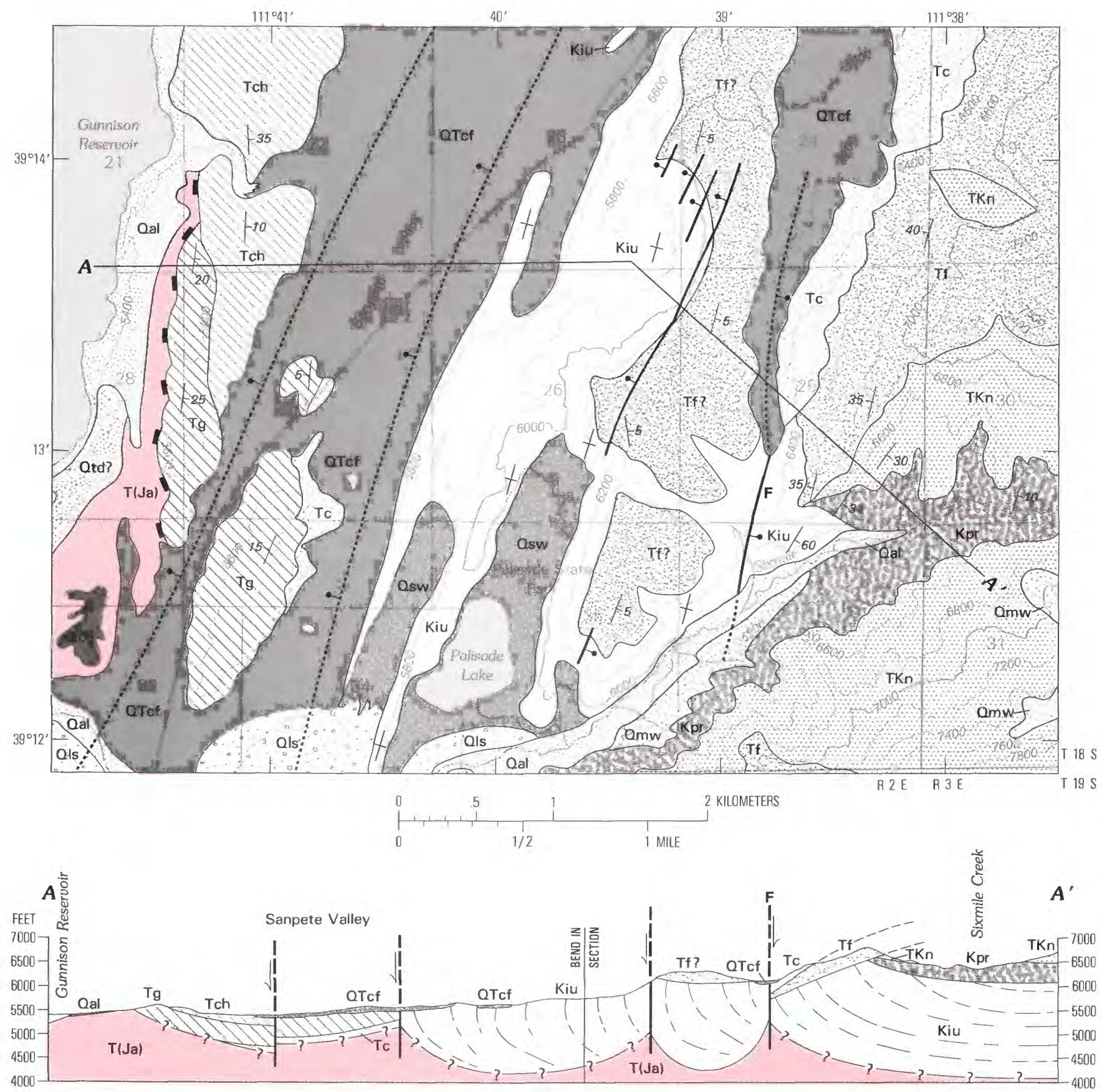

FIGURE 21 (above and facing page).-Geology of Sixmile Creek canyon area. Map and cross section show geology of part of area. Base modified from U.S. Geological Survey 1:24,000 Sterling (1966). Contour interval $200 \mathrm{ft}$. Area includes sectors north of Sterling, including part of Sanpete Valley, Palisade State Park, and the mouth of Sixmile Creek canyon. Strata represent part of east flank of Sanpete-Sevier Valley diapiric fold. When all or part of the Sanpete-Sevier Valley salt diapir was removed, the late Oligocene(?) version of the fold collapsed. Arapien mudstones, which I believe underlie the entire area, subsided into the newly formed void; this effectively removed the support for the overlying sedimentary strata which then collapsed, in part along high-angle faults and in part by gradual subsidence. Most of the crustal blocks were downthrown (western part of cross section) toward core of fold. Westward tilt of the Flagstaff
Limestone (Tf) defines the Wasatch monocline, which formed in response to this subsidence of the mudstones. Fault " $F$ " marks west margin of Wasatch monocline.

Sketch shows north valley wall at mouth of Sixmile Creek canyon. Two angular unconformities are exposed: The older is between the Sixmile Canyon Formation of the Indianola Group and the overlying Price River and North Horn Formations. The younger is between the Flagstaff Limestone and underlying strata. Near center and right edge of sketch, the Flagstaff Limestone truncates both North Horn and Price River strata. Left side of sketch shows Flagstaff strata cutting across steeply dipping beds of the Sixmile Canyon Formation of the Indianola Group. Compare this sketch with figure 31 , which displays relations near the mouth of Red Canyon in the Valley Mountains, some $20 \mathrm{~km}$ (12 mi) west. 

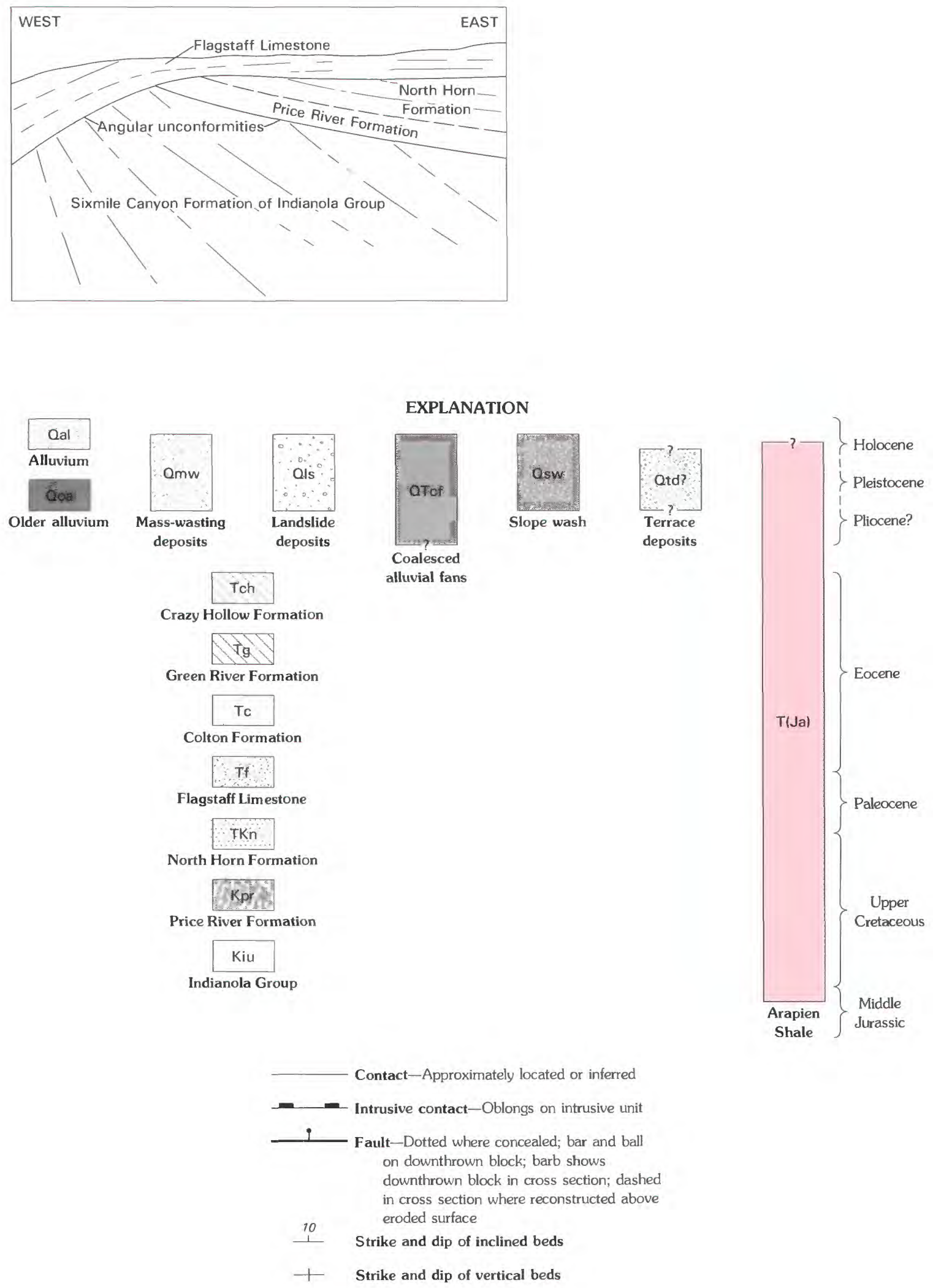

The salt diapir may have reactivated a third time to form still another daughter fold that again occupied the same site and had the same trend as the previous two folds (fig. 20, V). This reactivation is suggested by the westward dip of the Flagstaff strata exposed in the Red Rocks area (fig. 20, VI). Subsequently, the 
diapiric fold failed again, as salt was removed from the underlying diapir, and the overlying beds subsided into the resultant void. The end result was the development of the Wasatch monocline along the west flank of the Wasatch Plateau, even as another opposing monocline probably developed along the east flank of the Gunnison Plateau. This second monocline along the east flank of the Gunnison Plateau has been destroyed by erosion, and its remnants are now concealed beneath the alluvial floor of Sanpete Valley.

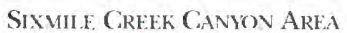

The Sixmile Creek canyon (F-4) area, east of Sterling, is some $10 \mathrm{~km}(6 \mathrm{mi})$ northeast of the Red Rocks area; the critical exposures underlie parts of secs. 25 , 26, 35, and 36 of T. 18 S., R. 2 E.

The exposures here closely resemble those of the Red Rocks area. The Indianola Group, exposed at and near the mouth of Sixmile Creek canyon, consists of vertical to steeply tilted beds that dip eastward (fig. 21). Near the east edge of its exposure, the uppermost unit of the Indianola Group-the Sixmile Canyon Formation-dips southeastward $30^{\circ}$ to $60^{\circ}$, and is truncated by an angular unconformity that also dips eastward but at about $10^{\circ}$. This unconformity is overlain by a thin sequence of Price River strata, which, in turn, is conformably overlain by a thin North Horn sequence. The Price River and North Horn sequence dips about $30^{\circ} \mathrm{E}$., and totals about $20 \mathrm{~m}(65 \mathrm{ft})$. This sequence is cut out near the western part of the exposure by Flagstaff Limestone, some 10 to $15 \mathrm{~m}$ ( 35 to $50 \mathrm{ft}$ ) thick, which dips westward at about $35^{\circ}$. Thus, the upturned edges of both the Price River and North Horn are unconformably overlain by Flagstaff Limestone. West of the pinchout of the Price River and North Horn sequence, the downwarped Flagstaff Limestone unconformably overlies the steeply tilted to vertical beds of the Sixmile Canyon Formation.

In summary, the stratigraphic sequence at the mouth of Sixmile Creek canyon is broken by two distinct unconformities: the first truncates the Indianola beds and is overlain by the Price River and North Horn sequence. The second not only truncates the upturned Price River and North Horn beds but also extends across the steeply inclined Indianola beds; west-dipping Flagstaff beds overlie this unconformity. Figure 22 depicts, in a series of diagrammatic sketches, how I visualize the relations in Sixmile Creek canyon to have formed. Subsidence of the sedimentary units, as shown in the last sketch, resulted in the development of the Wasatch monocline.
FIGURE 22 (facing page).-Diagrammatic cross sections suggesting how Sixmile Creek canyon area evolved, with resultant formation of the Wasatch monocline. All sections represent part of east limb of Sanpete-Sevier Valley diapiric fold. In views I-VII, ground surface speculative, not shown.

I. Geologic relations at the mouth of Sixmile Creek canyon. See figure 21 for geologic map of the area and sketch of north valley wall at the mouth of Sixmile Creek canyon. The geologic pattern is almost a mirror image of that exposed in the Red Rocks area to the west (assumed to be west limb of SanpeteSevier Valley diapiric fold); in essence, steeply dipping beds of the Sixmile Canyon Formation of the Indianola Group (Kis) are unconformably overlain by a Price River $(\mathrm{Kpr})$ and North Horn (TKn) sequence, which in turn is unconformably overlain by the Flagstaff Limestone ( $\mathrm{Tf}$ ).

II. During the first diapiric episode, an upward surge of the Sanpete-Sevier Valley salt diapir warped rocks of the Sixmile Canyon Formation (Kis) into a diapiric fold, mushroom-shaped in cross section.

III. The rate of uplift decreased and the fold was eroded to a surface of low relief. A Price River (Kpr) and North Horn (TKn) sequence was deposited on this surface.

IV. The beginning of the second diapiric episode was marked by a second upward surge of the salt diapir, which raised and deformed all strata. The newly deposited Price River and North Horn sequence was warped to form a diapiric fold, and the previously tilted beds of the Sixmile Canyon Formation were rotated to still steeper angles.

V. This second diapiric fold also was eroded to a near-horizontal surface. Flagstaff (Tf) was deposited across this surface, and in time still younger units (at least the Colton (Tc), and Green River ( $\mathrm{Tg}$ ) Formations) accumulated.

VI. Two alternative interpretations for what occurred next are possible: In the first, a renewed upward surge of the salt warped these newly deposited Tertiary units into a new diapiric fold. The second alternative suggests that as part of the salt diapir was removed, the overlying sedimentary units subsided into the resultant void to form a westward-facing monocline. I sketch the first alternative here, chiefly because the westward tilt of the Flagstaff and younger strata in the Red Rocks area to the west imply that a new fold was formed shortly after deposition of these younger Tertiary strata.

VII. Subsequent removal of salt from the Sanpete-Sevier Valley diapir resulted in failure of the fold. The mudstones of the Arapien sank into the newly created void, and the upturned country rocks, lacking the support of the mudstones, subsided to form the westward-facing Wasatch monocline.

VIII. Erosion and removal of younger units (Green River ( $\mathrm{Tg}$ ), and Colton (Tc)) expose the westward-dipping Flagstaff Limestone (Tf) overlying eastward-dipping strata (Kis, Kpr, TKn).

The Red Rocks and Sixmile Creek canyon exposures are unusual in two respects: (1) Most of the units are much thinner in these areas than in the Wasatch Plateau to the east, and (2) strata that are conformable only a kilometer or two away are separated here by striking angular unconformities. In the Sixmile Creek canyon area, for example, where exposures are good and easily traceable, the Price River and North Horn strata thicken gradually eastward, and attain thicknesses of hundreds of meters just a 

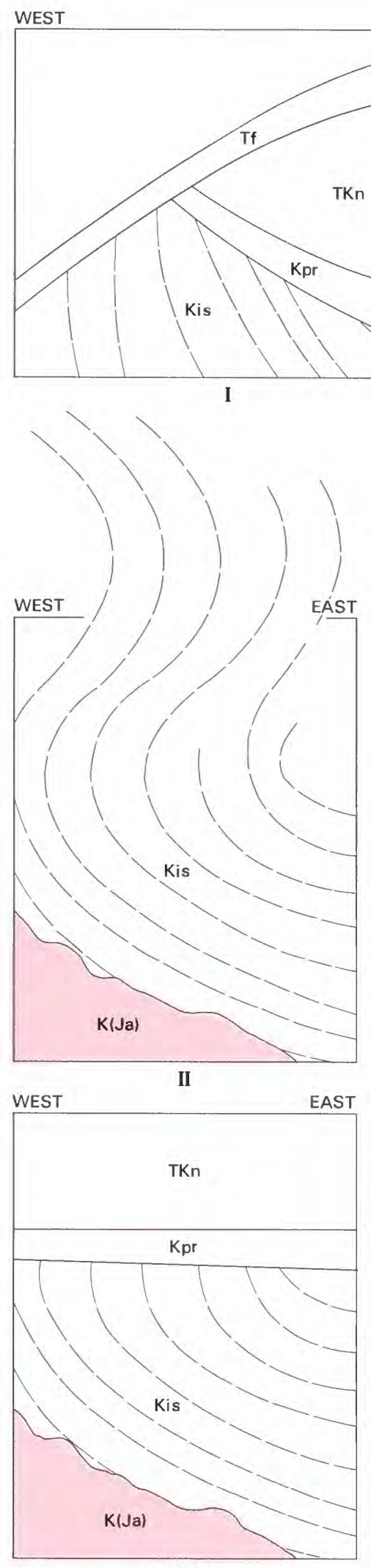

III
EAST
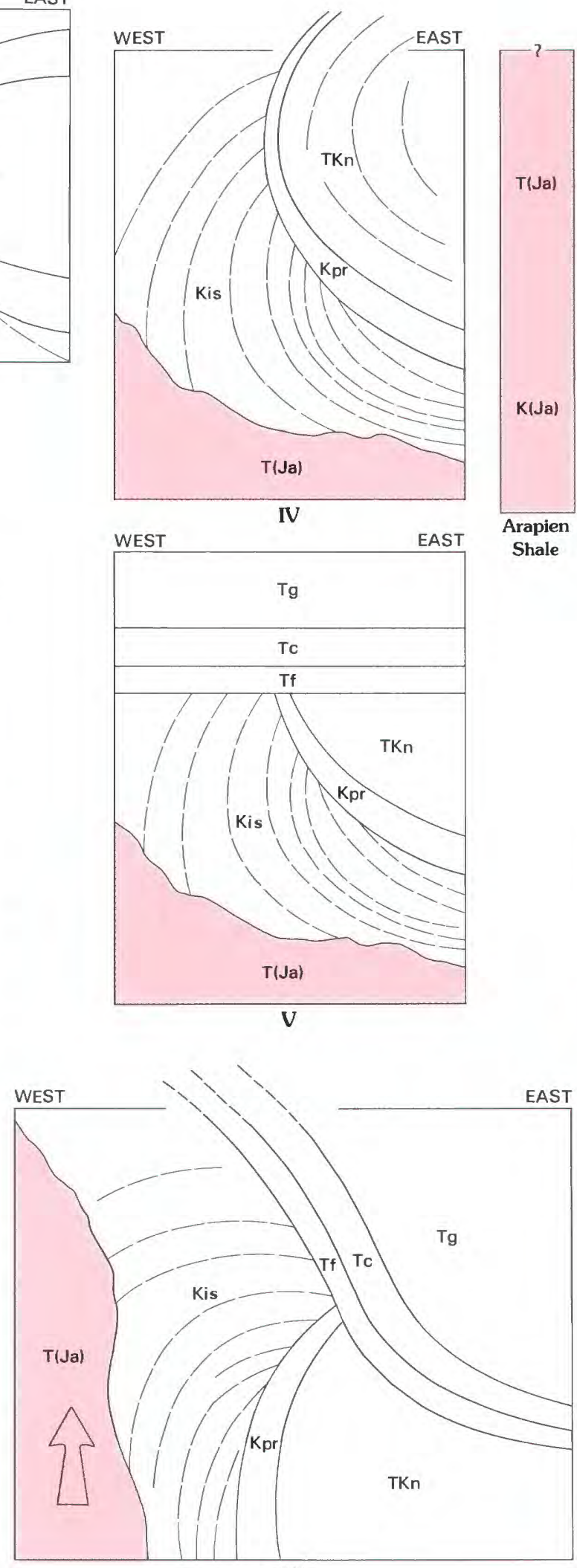

VI
EXPLANATION
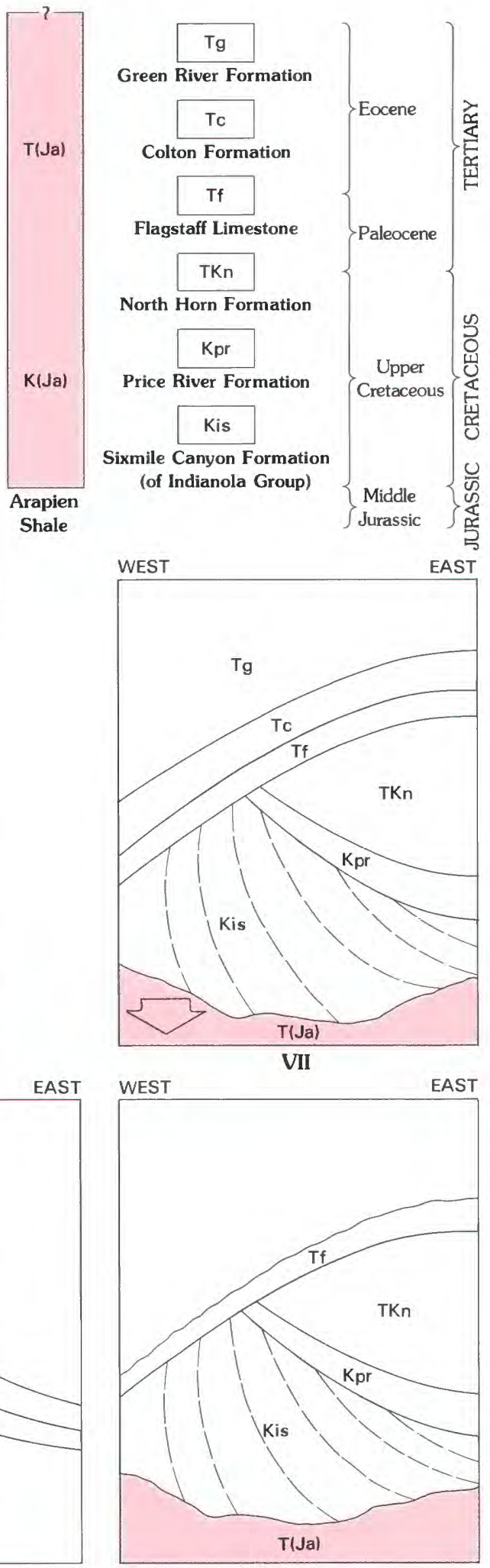

VIII 
few kilometers to the east. The North Horn and Flagstaff beds, unconformable at the canyon mouth, are conformable about $2 \mathrm{~km}(1.2 \mathrm{mi})$ to the east.

I interpret the exposures in the Red Rocks area to be remnants of the west limb of the Sanpete-Sevier Valley diapiric fold, and the similar exposures in Sixmile Creek canyon to be remnants of the opposite (east) limb of the same fold.

WALES GAP

Wales Gap (D-4), at the mouth of Wales Canyon, is along the east flank of the Gunnison Plateau, some $37 \mathrm{~km}(23 \mathrm{mi})$ north of the Red Rocks area. Essentially the same stratigraphic units are exposed at Wales Gap as at Red Rocks, but the Wales Gap rocks have been more intensely deformed.

At Wales Gap, overturned conglomerate beds of both the Indianola Group and the Price River Formation form a steep, narrow ridge (figs. 23A, 24). The structural relations between the two units are somewhat masked by their similar lithologies and by the low angular discordance between them (Spieker, 1946, pl. 24B). The overturned Indianola conglomerate beds form the eastern part of the ridge and dip eastward at about $50^{\circ}$ (fig. $23 B$ ). They abut, and stratigraphically underlie, overturned conglomerate beds of the Price River Formation that form the western part of the ridge. These Price River beds also dip eastward, but at about $80^{\circ}$ (fig. 25). Just west of the ridge the gray and red mudstone and brown sandstone beds of the North Horn Formation are right-side-up and dip gently westward. East of the ridge, overturned palered and orange mudstone, siltstone, and sandstone beds of the Cedar Mountain Formation, which dip about $60^{\circ} \mathrm{E}$., stratigraphically underlie the Indianola beds. The Cedar Mountain strata, in turn, are stratigraphically underlain by overturned light-brown and gray thin sandstone beds of the Twist Gulch Formation, which also dip about $60^{\circ} \mathrm{E}$. All units for which an upper and lower contact can be found are anomalously thin compared with their thicknesses elsewhere in the area.

I attribute the anomalous thinness of the sedimentary units to the gradual upwelling of the SanpeteSevier Valley diapir, and the deformation to repeated upward surges of the diapir.

In figure $25 \mathrm{I}$ suggest a sequence of events to explain these structural relations. At some time after Indianola strata were deposited, the Sanpete-Sevier Valley diapir surged upward and forced the Arapien mudstones to bow up and fold back the Twist Gulch, Cedar Mountain, and Indianola beds, forming a fan-
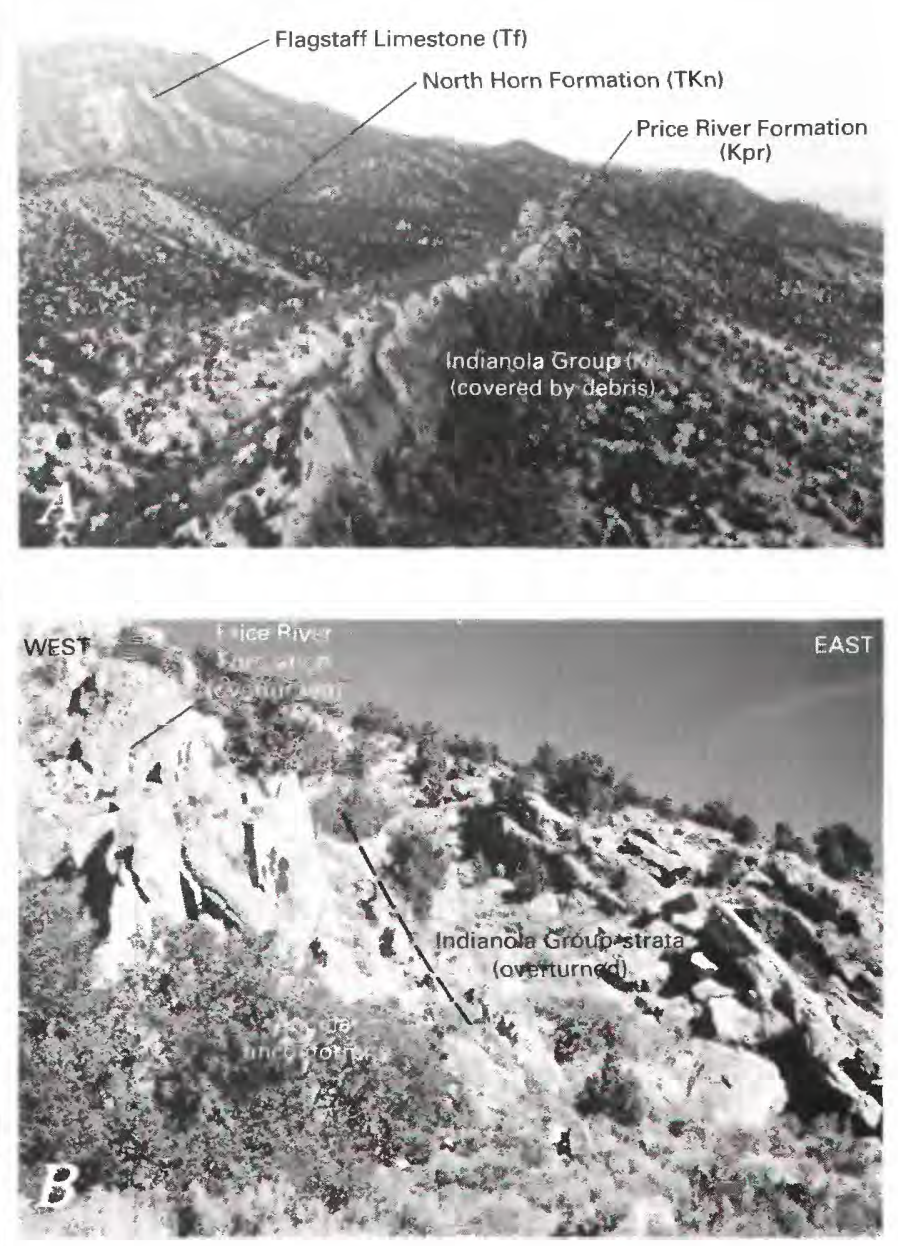

FigurE 23.-East front of Gunnison Plateau near Wales. A, Aerial view, looking north along east flank of the Gunnison Plateau. Wales Gap (D-4) is just beyond skyline. Overturned to vertical conglomerate beds of the Price River Formation (Kpr) and the Indianola Group ( $\mathrm{Ki}$ ) form the narrow, elongate, north-trending ridge. These upturned conglomerate beds abruptly flatten westward (left) in the subsurface, and in a distance as short as several kilometers assume the gentle westward dip suggested by the overlying North Horn (TKn) and Flagstaff (Tf) strata that form the steep, imposing front of the Gunnison Plateau (left side of photo). Photograph by D.A. Sprinkel, Placid Oil Company. B, View northward of the Indianola and Price River relations as exposed in a road cut (Wales Gap) through the north-trending ridge shown in $A$. Price River strata (left side of photograph) are vertical to overturned; Indianola beds (right side) are overturned and dip about $50^{\circ} \mathrm{E}$.

shaped fold (only the west flank of this fold is shown in fig. 25, sketch I). Although no evidence is available to indicate how the fold failed, most likely, removal of the salt caused collapse of the crestal part of the fold. Erosion then beveled the area to a surface of low relief. Price River sediments were deposited on this 
surface, and in time, these were covered by North Horn sediments (fig. 25, II). The sequence, thus, is identical to that postulated for the Red RocksSixmile Creek canyon area.

At some time during or after North Horn time the salt diapir welled upward once more, and again forced the Arapien mudstones to bow up and fold back the overlying strata. The Price River and North Horn sequence was probably warped into a fanshaped fold, and the underlying Indianola beds were rotated into overturned attitudes (fig. 25 , III). Subsequently, this newly formed fold failed, presumably when the supporting salt was removed. On the basis of exposures elsewhere in the area (as in the Red Rocks area), I assume that the area was again reduced to a surface of low relief. Flagstaff sediments were deposited on this surface, and these, eventually, were covered by a sequence of still younger Tertiary beds. Subsequently, when salt was removed from the causative salt diapir, the overlying Tertiary beds were let down to form an eastward-facing monocline-the East Gunnison monocline - comparable to and paired with the westward-facing Wasatch monocline. Erosion has since removed all traces of the East Gunnison monocline, leaving only the structurally complex west flank as evidence of the diapiric activity (fig. 25, sketch IV).

\section{ANCESTRAI WILLOW CREEK AREA}

Geonogic Setting;

The ancestral Willow Creek (G-3) area, also known as the Willow Creek gap, is some $8 \mathrm{~km}(5 \mathrm{mi})$ northeast of Salina (G-3) astride an ancestral course of Willow Creek. Two low cuestas that trend about N. $30^{\circ}$ E. dominate the area (fig. 26). The cuestas are collinear and the resulting ridge extends for some $4.5 \mathrm{~km}(2.7 \mathrm{mi})$ through parts or all of sections $26,27,34$, and 35 of T. 20 S., R. 1 E. The aligned cuestas parallel the crest of the White Hills, composed of deformed mudstone beds of the Arapien Shale, which is about $1.6 \mathrm{~km}(1 \mathrm{mi})$ to the northeast.

Sedimentary rocks exposed in and near the cuestas range from the Arapien Shale (Middle Jurassic) to the Crazy Hollow Formation (Eocene). All units exposed in the cuestas are anomalously thin compared to their thicknesses in and near the Wasatch Plateau some $8 \mathrm{~km}(5 \mathrm{mi})$ to the east. So, for example, the Flagstaff Limestone is about $30 \mathrm{~m}(100 \mathrm{ft})$ thick here, but more than $365 \mathrm{~m}(1,200 \mathrm{ft})$ thick where it caps the plateau.

In detail, the cuestas consist of steeply dipping to vertical beds of the Colton Formation and the under- lying Flagstaff Limestone (fig. 26). Some uncertainty and differences of opinion exist as to just what units should be included in the Flagstaff. Spieker (1949, p. 56) considered the Flagstaff in the Willow Creek area to be a composite unit consisting of a light-gray, fine-grained limestone bed plus some conglomerate beds that crop out on both sides of the near-vertical to vertical limestone. The conglomerate beds dip steeply and appear to conform to the attitude of the limestone bed. G.E. Moore, Jr., and K.E. Stanley (Ohio State University, written commun., 1979) considered only the limestone bed to be Flagstaff. They interpreted those conglomerate beds west of the limestone bed to be basal units of the Colton Formation, and those east of the limestone bed to be uppermost North Horn strata-in essence, a normal stratigraphic sequence. I offer a third interpretation. I concur with Moore and Stanley that the limestone bed is Flagstaff and that the conglomerate beds west of the limestone bed are basal Colton. I believe, however, that the conglomerate beds east of the limestone bed are part of a block of the Colton Formation that was downthrown along a high-angle normal fault that delineates the east side of the steeply inclined bed of Flagstaff Limestone. The fault, which follows the crests of the two cuestas, is marked in many places by vertical slickensides. Small steps, or heels, along the slickensides suggest that the crustal block east of the fault has been downthrown. The fault is best exposed along the north end of the northern cuesta, where beds of the Twist Gulch Formation, east of the fault, dip westward at $35^{\circ}$ to $65^{\circ}$ and abut vertical beds of the Flagstaff Limestone west of the fault (fig. 6A).

\section{DISCUSSION}

Figure 27 is a geologic map of the ancestral Willow Creek area. I include a series of diagrammatic sketches and cross sections that illustrate how I believe the ancestral Willow Creek area evolved. In my interpretation the welt of contorted Arapien Shale mudstones that makes up the White Hills is part of the exposed core of the Sanpete-Sevier Valley diapiric fold, and the two northeast-trending, aligned cuestas are the broken and dissected remnants of the fold's west flank. The east flank of the fold is not exposed; apparently it was obliterated by collapse and erosion, and now is concealed beneath surficial deposits. Its former position is followed approximately by the Cedar Mountain road (fig. 27).

I propose that the Sanpete-Sevier Valley salt diapir surged upward at some time after deposition of the Crazy Hollow Formation (Eocene), presumably during 


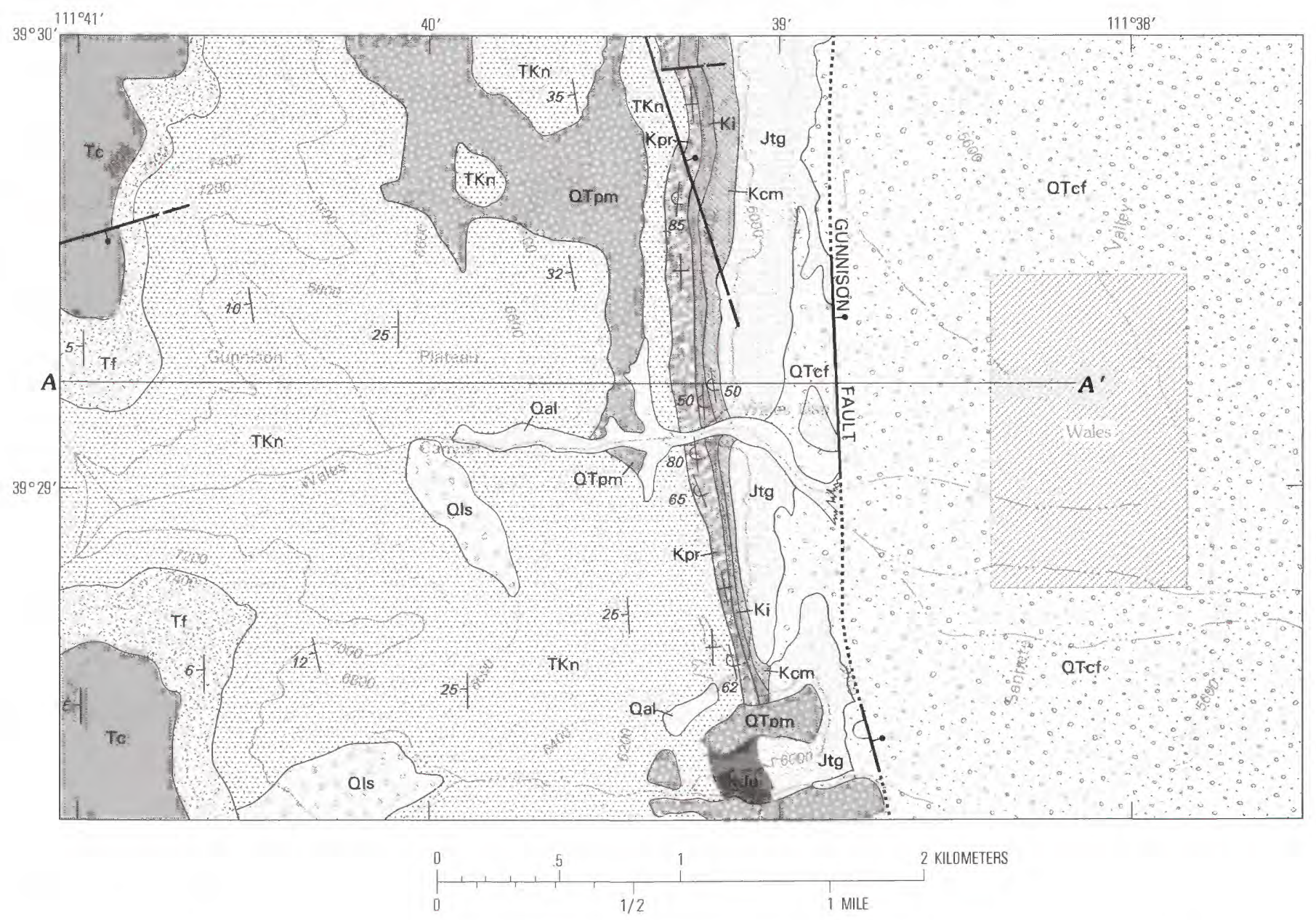

A

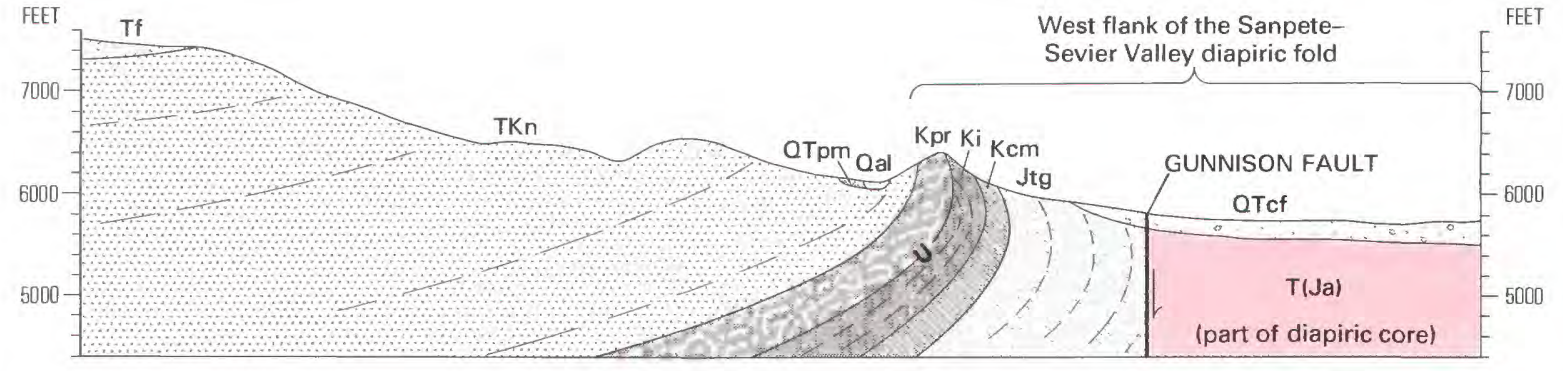

Figure 24 (above and facing page).-Geology of an area near Wales, Utah. A small area along the east flank of the Gunnison Plateau, centered on Wales Gap, displays well the unusual structural and stratigraphic relations that characterize the plateau's east flank. Geology by M.P. Weiss, modified by I.J. Witkind. Base modified from U.S. Geological Survey 1:24,000 Wales (1965). Contour interval $200 \mathrm{ft}$.

Vertical and overturned beds of the Price River Formation and Indianola Group form an elongate, narrow, north-trending ridge. These clastic units are stratigraphically underlain by overturned beds of both the Cedar Mountain and Twist Gulch Formations.
I interpret the vertical and overturned Price River and older strata to be part of the west flank of the Sanpete-Sevier Valley diapiric fold; surficial deposits that floor Sanpete Valley conceal the bulk of the fold. The attitude of these upturned Price River and older beds resulted from repeated upward movements of the Arapien Shale. See figure 25 for a diagrammatic explanation.

The Gunnison fault, a much younger feature, likely formed when the salt in the core of the Sanpete-Sevier Valley fold dissolved, resulting in collapse of the crestal part of the fold and subsidence of the overlying strata. 


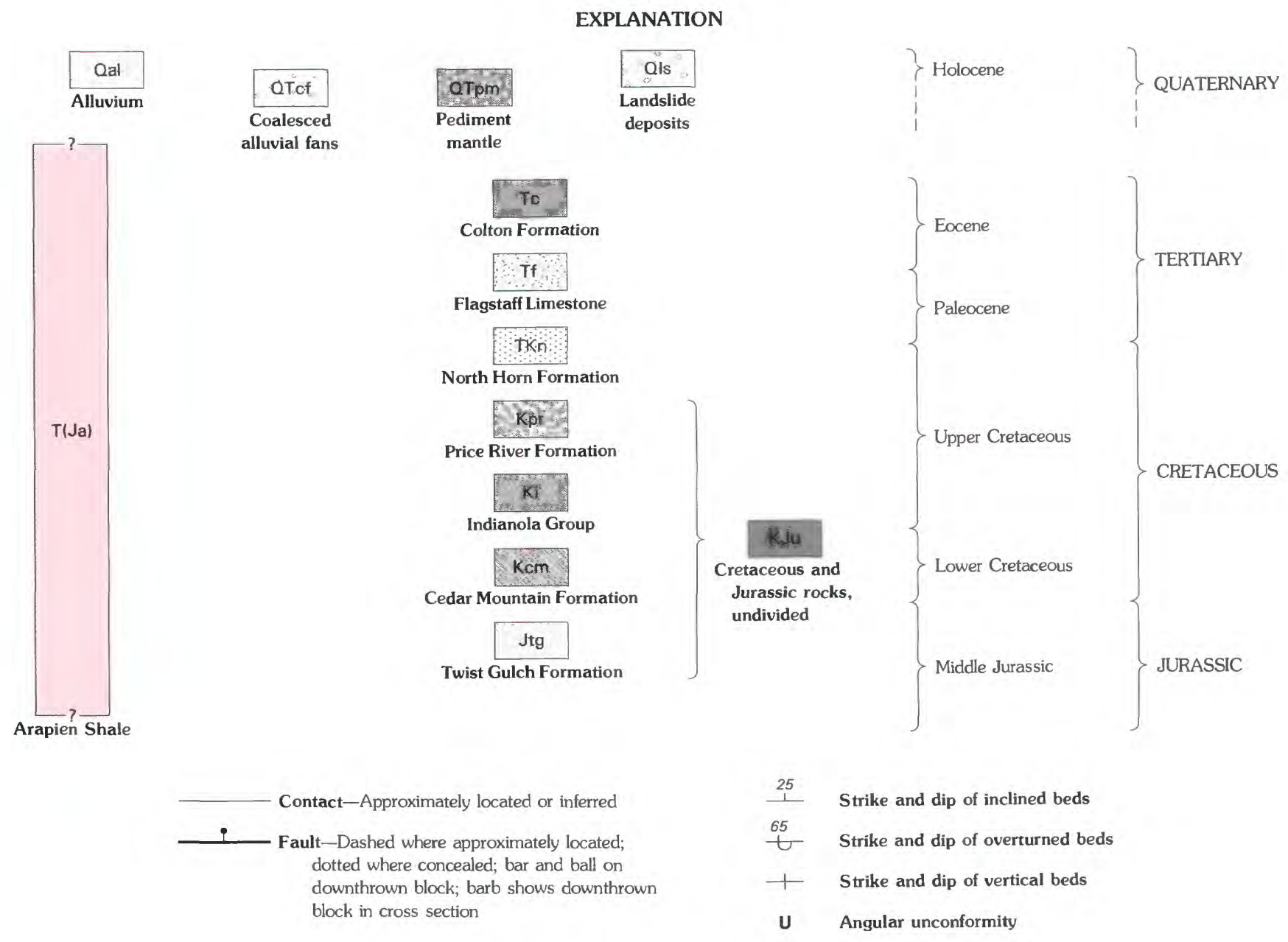

post-Eocene time. During this upward surge the salt forced the mudstone beds of the Arapien Shale to bow up the overlying sedimentary strata and thus form a fan-shaped diapiric fold. Only the west limb of this fold is shown in stage I of cross sections $A-A^{\prime}, B-B^{\prime}$, and $C-C^{\prime}$, figure 27. Upon removal of the salt, the crest of the fold collapsed unevenly between highangle faults that developed along the flanks of the fold (stage II of cross sections $A-A^{\prime}, B-B^{\prime}$, and $C-C^{\prime}$, fig. 27). The western fault developed adjacent to and east of the vertical bed of Flagstaff Limestone. Depending upon the amount of stratigraphic throw, different units, east of the fault, were downthrown and juxtaposed against the Flagstaff Limestone. As shown in cross section $A-A^{\prime}$, Twist Gulch beds, part of the downthrown crest, were dropped against vertical Flagstaff beds. In cross section $B-B^{\prime}$, steeply dipping to near-vertical beds of the Colton were downthrown against the Flagstaff. The geologic relations shown in interpretation $B-B^{\prime}$ form the basis for my suggestion that the correct stratigraphic sequence at Willow Creek gap involves near-vertical to vertical Flagstaff beds flanked by near-vertical Colton strata. Colton strata west of the Flagstaff Limestone conformably overlie the Flagstaff; Colton strata east of the Flagstaff are in fault contact with that unit (stage III of cross section $B-B^{\prime}$ ).

Other unusual geologic relations in the same area can also be explained by invoking different amounts of downthrow along the same vertical fault. So, for example, about $365 \mathrm{~m}(1,200 \mathrm{ft})$ east of the cuesta south of the Willow Creek road, beds of the Flagstaff Limestone crop out along a small knoll (fig. 27). These limestone beds are overturned and dip about $85^{\circ}$ E. Stratigraphically, they underlie overturned beds of the Colton Formation that also dip eastward. As shown in cross section $C-C^{\prime}$, figure 27 , these unusual stratigraphic relations are readily explained by again invoking downthrow of the west limb of the diapiric fold. 

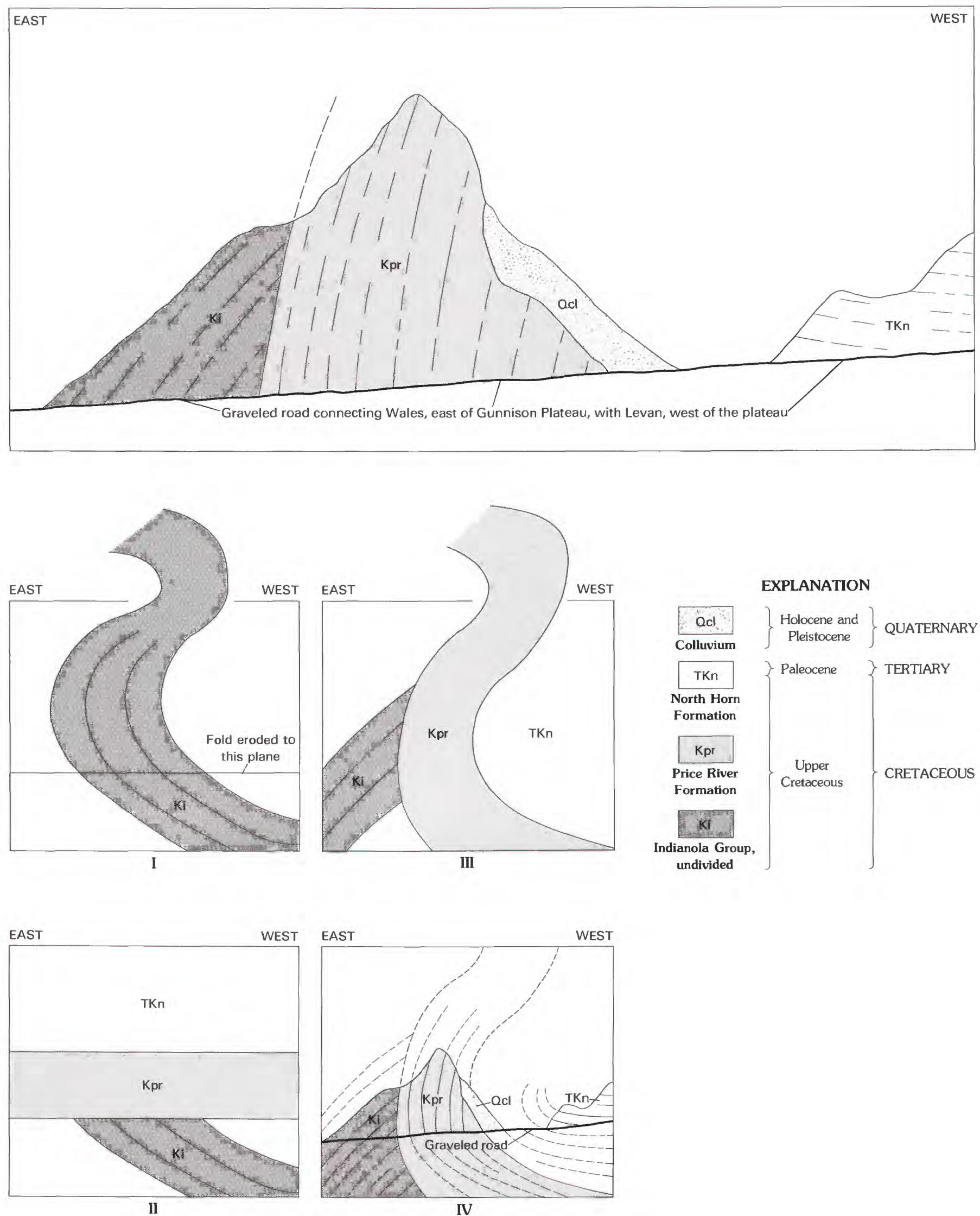
At the north end of the cuesta north of the Willow Creek Road, where Twist Gulch beds abut vertical Flagstaff beds, the amount of downthrow along the fault is somewhat less than the amount of throw involved in the juxtaposition of Colton beds against the Flagstaff. As all units, however, are anomalously thin in this locality, the differences in amount of throw between the two areas are not excessive. Here, as in the Red Rocks-Sixmile Canyon area, the crustal blocks adjacent to a fault are downthrown valleyward (eastward in the ancestral Willow Creek area) toward the core of the collapsed fold.

I stress that these geologic relations in the ancestral Willow Creek area represent but one episode in the many that mark the repeated growth and collapse of the Sanpete-Sevier Valley salt diapir. Because Tertiary units-Flagstaff, Colton, Green River, and Crazy Hollow-are steeply tilted, the deformation must have occurred at some time after Crazy Hollow strata (Eocene) were deposited-long after Sevier thrusting had come to an end. It would

FiguRE 25 (facing page).-Wales Gap (D-4), along east flank of the Gunnison Plateau. Diagrammatic field sketch, looking south, shows exposures along south wall of Wales Gap. Both the Indianola Group (Ki) and the Price River Formation (Kpr) are overturned and dip eastward (left) but at different angles. Both units consist of coarse conglomerate beds that are very much alike. Sketches I to IV suggest how these relations may have formed as a result of repeated episodes of salt diapirism. Area is part of west flank of the Sanpete-Sevier Valley diapiric fold; Sanpete-Sevier Valley salt diapir (not shown) is concealed to the east (left) beneath alluvial floor of Sanpete Valley.

I. Conglomerate beds of the Indianola Group (Ki) were deformed into a fan-shaped fold as a result of an upward surge of the Sanpete-Sevier Valley salt diapir.

II. Subsequently, the fold collapsed, and was eventually eroded to a broad surface of low relief. On this newly formed surface, sediments of the Price River Formation (Kpr) were deposited, and in time these were mantled by sediments of the North Horn Formation (TKn). Although not shown in these diagrammatic sketches, both the Price River (Kpr) and North Horn (TKn) Formations thin in this area, presumably as a result of a slow but persistent upwelling of the Sanpete-Sevier Valley salt diapir. III. Another rapid upward surge of the Sanpete-Sevier Valley salt diapir deformed the area once again. The newly deposited Price River (Kpr) and North Horn (TKn) Formations were deformed into a fan-shaped fold whose general trend and position coincide closely with that of the previously formed diapiric fold. The tilted Indianola strata $(\mathrm{Ki})$ were overturned.

IV. Collapse of the most recently formed fold and subsequent erosion have almost obliterated all evidence of the two diapiric folds. Remnants of the deformed rocks are exposed only along the east flank of the Gunnison Pleateau. (Compare with field sketch.) About $0.8 \mathrm{~km}(0.5 \mathrm{mi})$ to the west (right), both the Indianola (Ki) and Price River (Kpr) strata flex sharply in the subsurface and conformably underlie the North Horn (TKn). seem, therefore, that of the three major diapiric episodes recognized in the Red Rocks-Sixmile Canyon area, only the third episode, (late(?) OligocenePliocene(?)), is represented in the ancestral Willow Creek area. All evidence of the first and second diapiric episodes is still concealed.

\section{GUNNISON RESERVOIR AREA}

The previous areas discussed demonstrate that consolidated sedimentary strata were repeatedly deformed during the Cretaceous and Tertiary, presumably as a result of the recurrent growth and collapse of the Sanpete-Sevier Valley salt diapir. In my opinion, the results of these diapiric episodes can be recognized throughout much of central Utah, and I believe that they determined the structural pattern of central Utah. Deformation was extensive and, although localized in specific belts, extends along strike for tens of kilometers. By contrast, in several small areas evidence suggests that diapirism may have persisted into the late Tertiary or Quaternary. In one such area, along the east shore of the Gunnison Reservoir (F-3), semiconsolidated sediments have been warped into a deformational pattern that is strikingly like those discussed previously.

Beds of semiconsolidated gravels, tilted on end, crop out along the east side of Gunnison Reservoir, chiefly in the SE $1 / 4$ sec. 21 , T. 18 S., R. 2 E. (fig. 28). Near-horizontal beds of younger gravels overlie these vertical gravels, and the angular unconformity between the two gravels is as spectacular as any of the angular unconformities exposed in the SanpeteSevier Valley area. The discordant relations between the two gravels does not extend for more than $1 \mathrm{~km}$ $(1 / 2 \mathrm{mi})$ and has been found only near the reservoir.

The age of the vertical gravels is unknown, but their lack of consolidation and their thin caliche rinds imply that they were probably formed during the late Tertiary (Miocene or Pliocene) or Pleistocene. I tentatively correlate these vertical gravels with the Axtell Formation (Spieker, 1949, p. 38), which Spieker (1949) believed may be of "late Tertiary" age. Elsewhere in this general area several small deposits of sand and gravel, correlated with the Axtell Formation, have been warped into synclines with dips as high as $45^{\circ}$ (Gilliland, 1963, p. 121 and plate 3, fig. 2; Hardy, 1952 , p. 60). One of these localities is near a small dome in the ancestral Willow Creek area (p. 29) where a pediment mantle of sand and gravel dips northwestward at about $20^{\circ}$ (fig. 14A). 


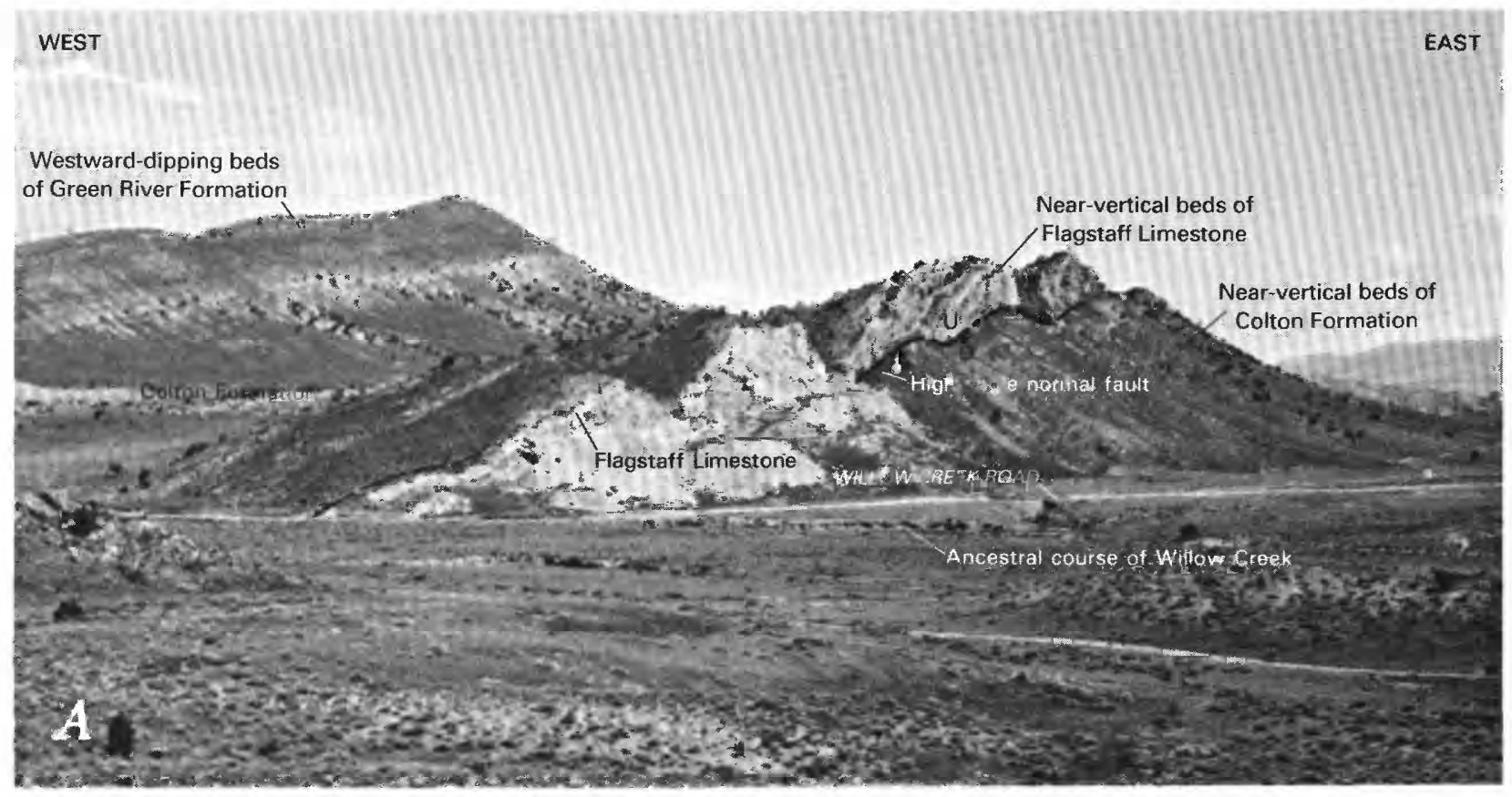

EAST

WEST

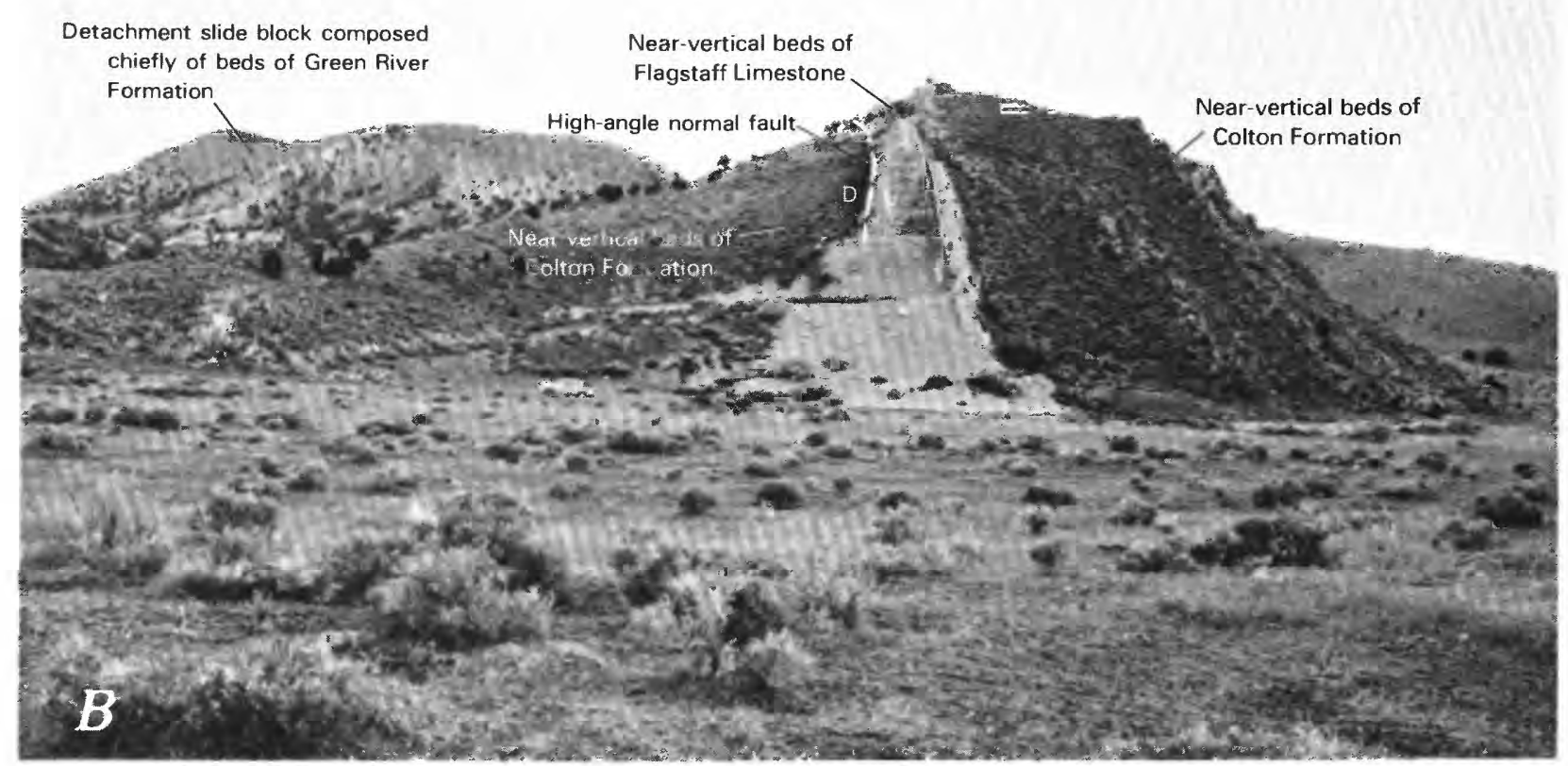

How the lowermost gravels exposed near Gunnison Reservoir were tilted to a vertical position is not clear. Although it is possible that they are part of a slump block that was tilted to steeper and steeper angles during successive valleyward rotational slumps, their vertical attitude suggests that this origin is unlikely. A more reasonable explanation, it seems to me, is that they were bowed up and folded back to form a diapiric fold by the upward movement of part-a cell-of the much larger Sanpete-Sevier Valley salt diapir, the crest of which underlies the reservoir, directly west of the vertical gravels. If so, these vertical gravels represent the east flank of a reactivated segment of the north-trending SanpeteSevier Valley diapiric fold.

Prof. M.P. Weiss, of Northern Illinois University, has suggested (oral commun., 1987) that the gravels may have been tilted to their vertical position as a 
Figure 26 (facing page).--Views of ancestral Willow Creek area. These exposures are part of west flank of the Sanpete-Sevier Valley diapiric fold. Structural relations reflect collapse of the crest of the fold between two high-angle normal faults (a graben), of which only the western fault is shown here. ( $U$, relatively upthrown block; D, relatively downthrown block.) See geologic map and cross sections, figure 27, for additional details. A, View, looking northward, of the cuesta north of Willow Creek road. West (left) of the near-vertical Flagstaff Limestone, stratigraphic sequence is normal, extending through the Colton Formation into the Green River Formation. A high-angle fault, however, flanks east (right) edge of the Flagstaff Limestone, and Colton strata are downthrown against the Flagstaff Limestone. (See geologic map, fig. 27.) $B$, View, looking southward, of the cuesta south of the Willow Creek road. Colton strata west (right) of the high-angle fault are part of the normal stratigraphic sequence; those Colton strata east (left) of fault are downthrown, along a high-angle normal fault, against vertical beds of Flagstaff Limestone. (Compare with cross section $C-C^{\prime}$ (III), fig. 27. Note that view shown here is reversed with respect to that cross section.) As these vertical and near-vertical strata are traced southward, they pass below a westward-inclined slide block composed of Green River strata.

result of upward movement by an unrecognized diapir that underlies that sector of Sanpete Valley north of Sterling and directly east of the upturned, vertical gravels. In Weiss' interpretation, the tops of the upturned gravels would be to the west. In my interpretation, the tops would be to the east.

I do not know how the diapiric fold was destroyed. Presumably it collapsed, much as postulated for those diapiric folds previously discussed, and the fold remnants were then eroded during the late Pliocene or early Pleistocene to form an even surface of local extent.

Younger sands and gravels, carried either by Pleistocene(?) streams or by Holocene descendants of those streams, were spread across this newly formed surface. Subsequent erosion by the San Pitch River exposed this remnant.

Seemingly, the driving salt has moved throughout much of the late Mesozoic and Cenozoic, and probably is continuing to well upward slowly today. Pediment gravels that overlie Arapien Shale exposures, near the junction of Twelvemile Creek with the San Pitch River (the northeast corner of sec. 24, T. 19 S., R. 1 E.), dip about $25^{\circ}$ NW. (M.P. Weiss, Northern Illinois University, written commun., 1989). These gravel exposures, as well as the vertical gravels exposed near Gunnison Reservoir, imply that the underlying salt diapirs are still active; if so, they pose a potential threat to man-made structures (Witkind, 1981).

\section{REDMOND DIAPIRIC FOLD}

The surface evidence for the Redmond diapiric fold (fig. 16, 2), originally named the Redmond Hills anticline by Gilliland (1963, p. 121), consists of a string of Arapien Shale outcrops that begins at Redmond (G-3) and extends as far north as Gunnison (F-3) (fig. 8). A gravity low coincides with the string of Arapien outcrops, and in my view this low reflects the crest of the diapiric fold (fig. 52). Gravity data (fig. 52) imply that the Redmond fold branches off the Sanpete-Sevier Valley fold near Salina (G-3), and then extends northward to some indefinite point beyond Gunnison, possibly joining the Levan fold (fig. 16, 3).

On the assumption that the Redmond fold does extend, at least, from near Salina to Gunnison, the fold has a minimum length of about $49 \mathrm{~km}(30 \mathrm{mi})$, and trends almost due north. I interpret a small east-dipping (valleyward) exposure of Green River(?) beds (p. 31) (in the $\mathrm{S} 1 \frac{1}{2}$ sec. 12, T. $20 \mathrm{~S}$., R. 1 W.), about $8 \mathrm{~km}(5 \mathrm{mi})$ north of Redmond, to be a remnant of the east flank of the fold (fig. 14B).

\section{SEVIER BRIDGE RESERVOIR DIAPIRIC FOLD}

Generally, Arapien Shale outcrops flanked by upturned, commonly vertical to overturned beds of consolidated sedimentary rock identify many diapiric folds. In places, however, the Arapien beds, being soft and easily eroded, are concealed beneath surficial deposits and only the upturned beds reflect the presence of the fold. Thus, for example, at the south end of the Sanpete-Sevier Valley fold (fig. 16, 1), west of Mayfield (F-3), the Arapien Shale forms the White Hills (G-3). I interpret these Arapien outcrops to be the core of the Sanpete-Sevier Valley fold, and the adjacent upturned beds (along the west flank of these exposures) to be part of the west limb of the fold. As these Arapien exposures are traced northward they pass below the alluvial fill of Sanpete Valley, and only upturned vertical to overturned Indianola beds, as, for example, at Wales Gap (D-4), indicate the position and trend of the fold.

By contrast, in the Sevier Bridge Reservoir (E-2) area, Arapien beds are not exposed, and only a narrow band of steeply tilted to overturned conglomerate beds of the Indianola Group exposed along the northeast flank of the Valley Mountains suggests the presence of a diapiric fold (fig. 16, 4; fig. 29A). Additional evidence, including both the complex structural relations and the anomalous depositional thinning best displayed at Red Canyon (E-2) along the northeast 


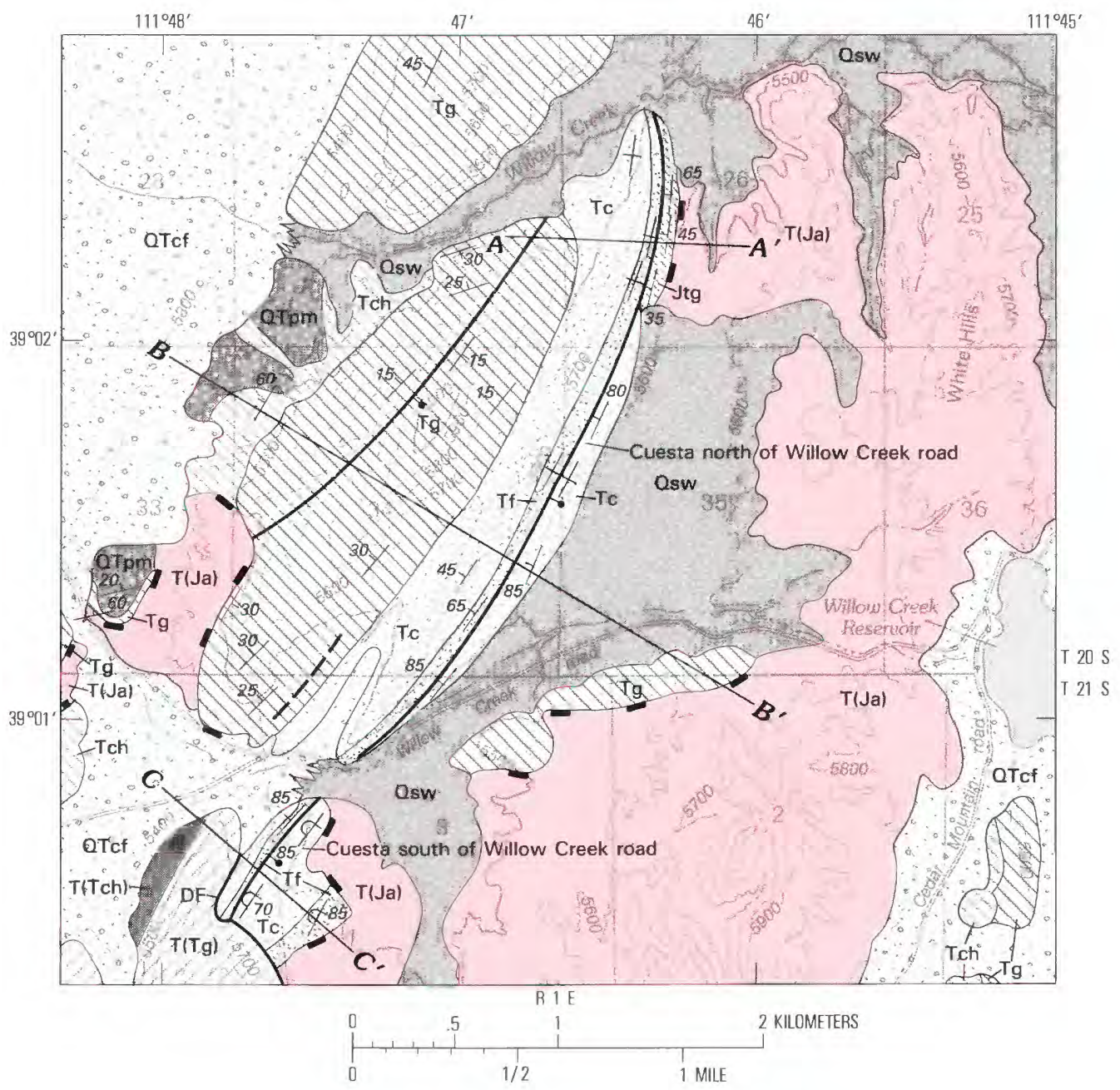

FIGURE 27 (above and following pages).-Geology of ancestral Willow Creek area, plus cross sections, across part of west limb of the late(?) Oligocene version of the Sanpete-Sevier Valley diapiric fold. Base modified from U.S. Geological Survey 1:24.000 Redmond (1966). Contour interval $100 \mathrm{ft}$.

In the three schematic cross section panels labeled I, reactivation of the Sanpete-Sevier Valley salt diapir (not shown) forced up the mudstones of the Arapien Shale ( $T(\mathrm{Ja})$ ), which in turn bowed up (arrows) the overlying sedimentary strata to form a diapiric fold, roughly mushroom shaped in cross section. In places, the beds were folded back and overturned; cross-sectional shape of the fold differs from place to place along the fold's length. The three schematic cross-section panels labeled II represent failure of fold along a high-angle normal fault. The three cross-section panels labeled III show present-day configuration.

Cross section $A-A^{\prime}$.

I. The beds were bowed up and folded back to form a fan-shaped fold. Only the west flank of that fold is shown.

II. Upon partial removal of the salt core (not shown) the fold collapsed between two high-angle faults. Only the west fault is shown. Crest of fold was dropped down against the vertical to overturned beds of the relatively upthrown limb.

III. After erosion, only remnants ( Jtg) of the downthrown limb are preserved, juxtaposed by a fault against vertical beds of the Flagstaff Limestone (Tf). 
EXPLANATION
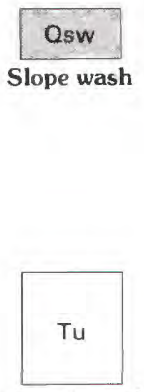

Tertiary units, undivided

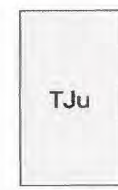

Paleocene, Cretaceous and Jurassic units, undivided

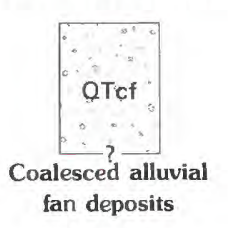

Pediment mantle

Unconformity
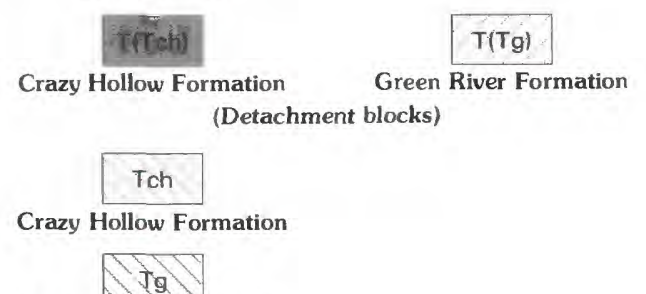

Green River Formation
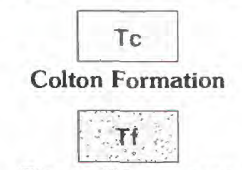

Flagstaff Limestone

$\mathrm{TKn}$

North Horn Formation

Ntg

Twist Gulch Formation
(Detachment blocks)

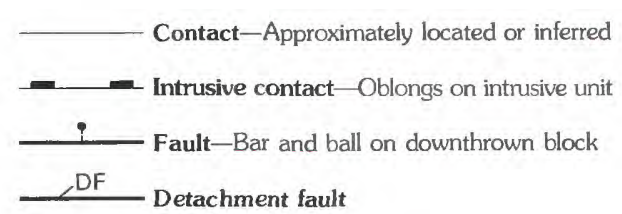

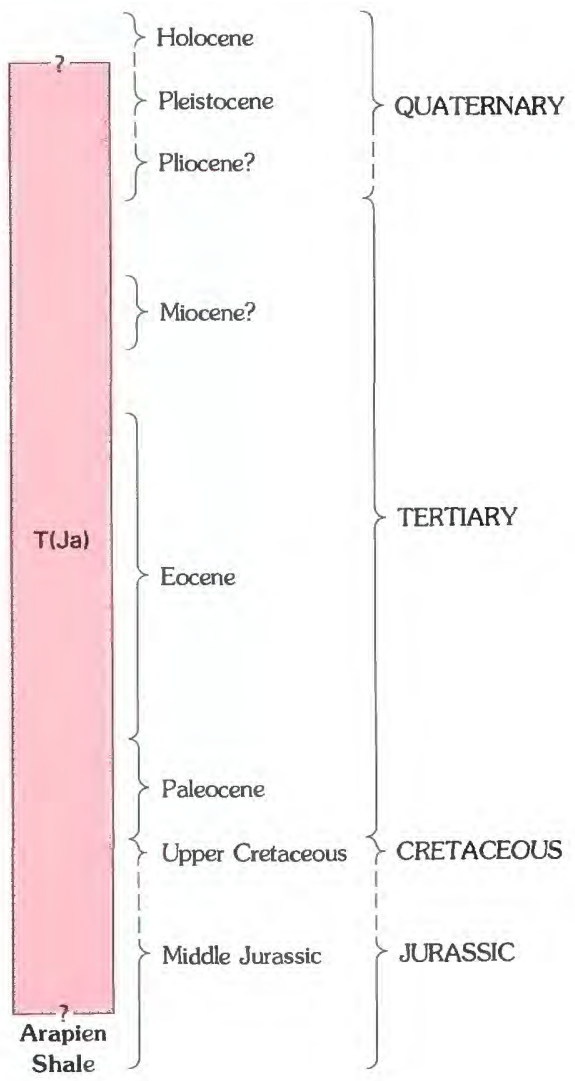

$\stackrel{45}{1}$ Strike and dip of inclined beds

1 Strike and dip of vertical beds

to

Cross section $B-B^{\prime}$ :

I. The beds were bowed up but not overturned. Only the west flank of the fold is shown.

II. Upon partial removal of the salt core (not shown), the fold collapsed between two high-angle faults (only the faults that are part of the west fault zone are shown), and the crest of the fold dropped down against vertical to steeply tilted beds of the relatively upthrown limb.

III. After erosion, beds of the Colton Formation (Tc) (of the downthrown limb) are preserved, juxtaposed along one of the west faults, against vertical beds of the Flagstaff Limestone (Tf). In this area, then, the Flagstaff Limestone (Tf) is both overlain and underlain by the Colton Formation (Tc).

Cross section $C-C^{\prime}$ :

I. The beds were bowed up and folded back. Only the west flank of the fold is shown.

II. Upon partial removal of the salt core (not shown), the fold collapsed along a high-angle fault and the overturned limb of the fold dropped down against vertical to overturned beds of the relatively upthrown limb.

III. After erosion, overturned beds of the Colton Formation (Tc) are preserved, juxtaposed by a fault, against steeply dipping to vertical beds of the Flagstaff Limestone (Tf). In this area, the Colton Formation (Tc) (east of the high-angle fault) is both overlain and underlain by the Flagstaff Limestone (Tf). A photograph of this area, fig. 26B, shows these units as viewed from the north (so that, in essence, the view is reversed). 

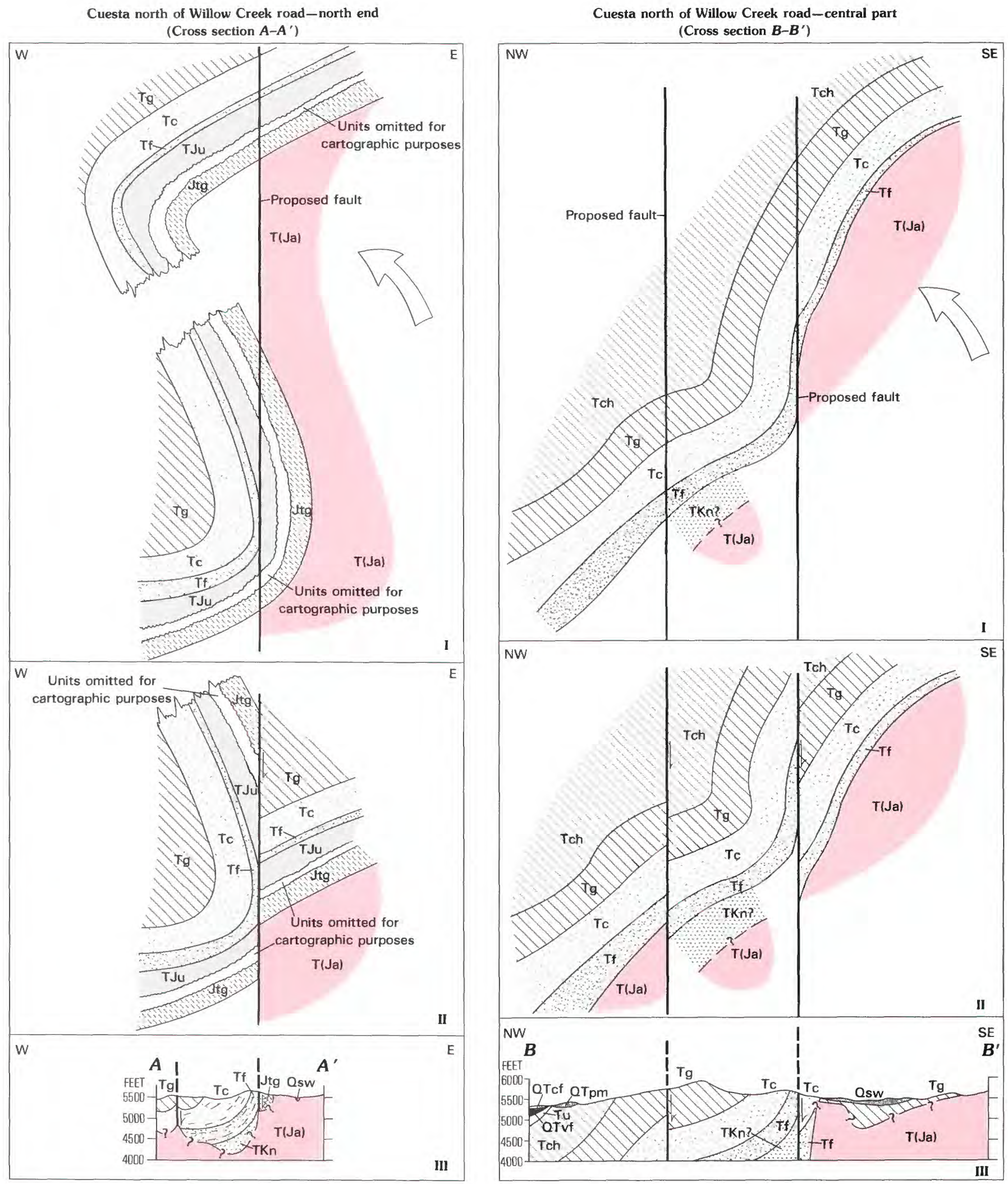

FIGURE 27 (above and facing column)-Continued.-How the ancestral Willow Creek area may have evolved. 

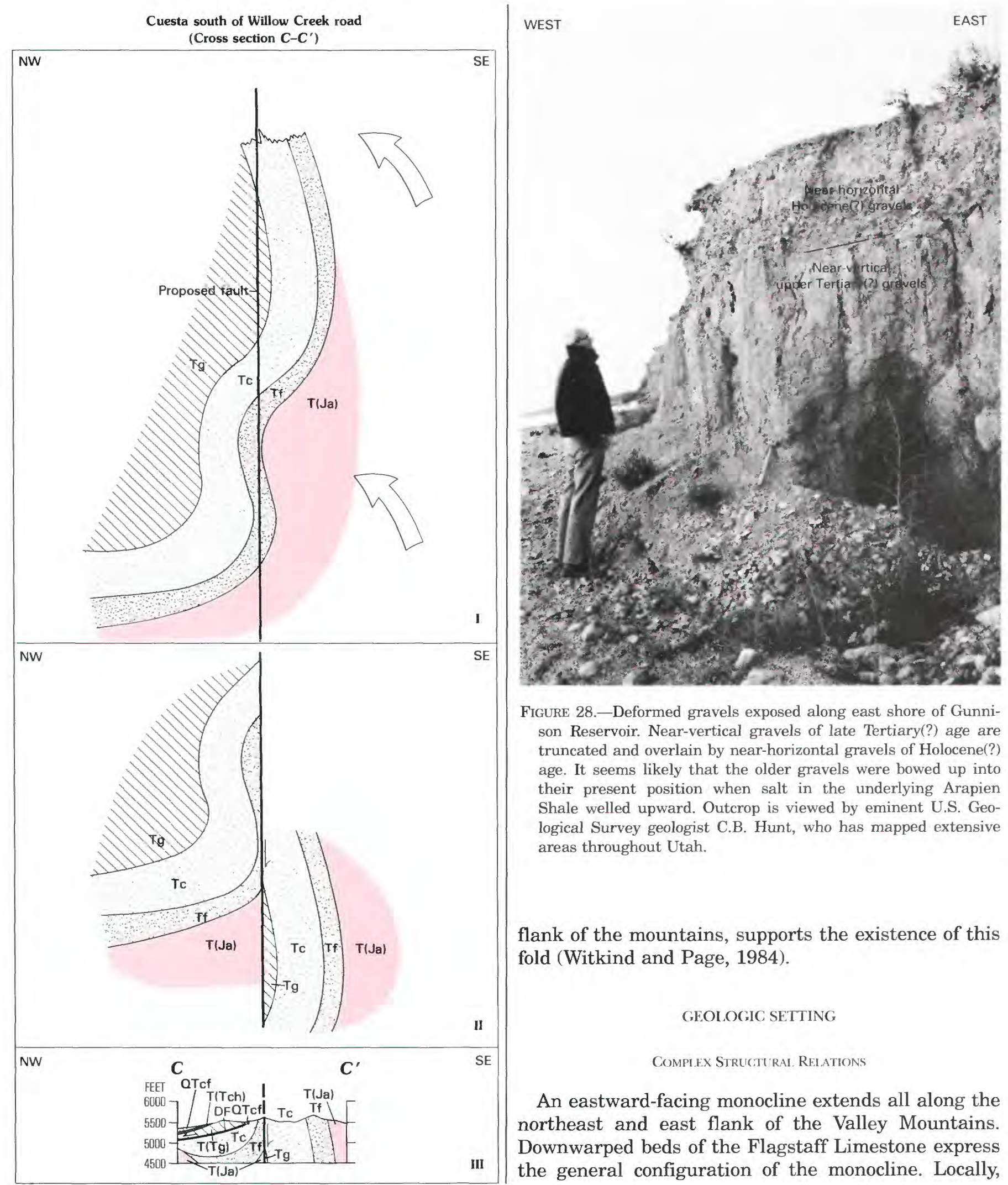

FIGURE 28.-Deformed gravels exposed along east shore of Gunnison Reservoir. Near-vertical gravels of late Tertiary(?) age are truncated and overlain by near-horizontal gravels of Holocene(?) age. It seems likely that the older gravels were bowed up into their present position when salt in the underlying Arapien Shale welled upward. Outcrop is viewed by eminent U.S. Geological Survey geologist C.B. Hunt, who has mapped extensive areas throughout Utah.

flank of the mountains, supports the existence of this fold (Witkind and Page, 1984).

\section{GEOLOGIC SETTING}

\section{Compiex Structitrai. Rei.ations}

An eastward-facing monocline extends all along the northeast and east flank of the Valley Mountains. Downwarped beds of the Flagstaff Limestone express the general configuration of the monocline. Locally, 

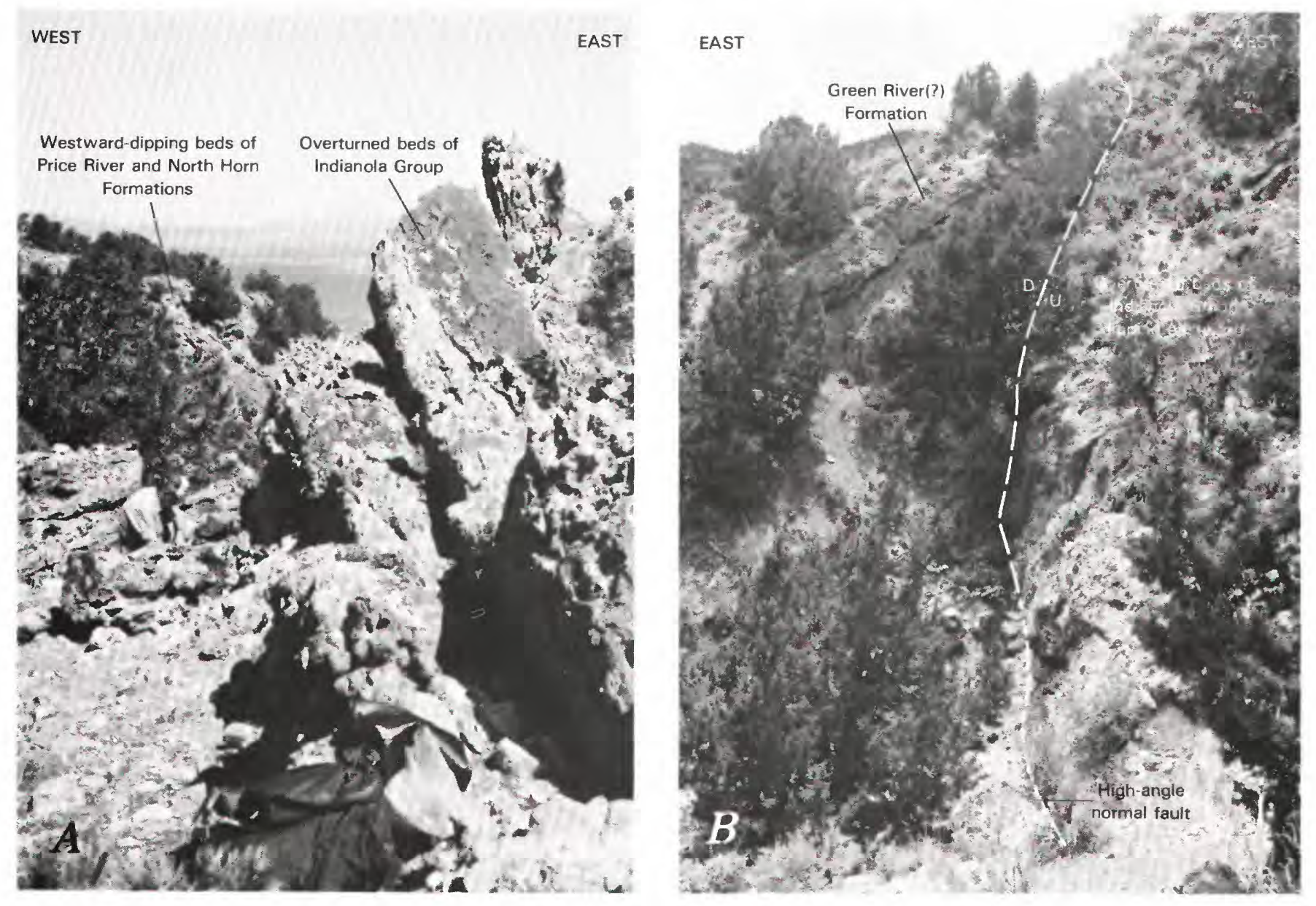

FIGURE 29.-Exposures along northeast flank of the Valley Mountains near Yuba Dam. A, Eastward-dipping, overturned beds of the Indianola Group. Locally these beds are vertical or right-side-up and dip steeply to the south and southwest. Price River strata, exposed on distant hillside behind geologist, dip moderately westward and unconformably overlie the overturned Indianola. $B$, Beds of the Green River(?) Formation are downthrown along a high-angle normal fault and juxtaposed against overturned to steeply dipping beds of the Indianola Group. U, relatively upthrown block; D, relatively downthrown block.

these downwarped beds are overlain conformably by younger strata, chiefly units of the Colton, Green River, and Crazy Hollow Formations. Near Yuba Dam, the monocline has been breached for a length of almost $8 \mathrm{~km}(5 \mathrm{mi})$, with the breached area extending from the $\mathrm{N} 1 / 2$ sec. 8 , T. 17 S., R. $1 \mathrm{~W}$. on the north, to C sec. 29 , T. 17 S., R. 1 W. on the south. The strata exposed in the breached area, rather than conforming in attitude to the downwarped beds that form the monocline, are tilted at unusual and varying angles. So, for example, the basal beds exposed, part of the Indianola Group, are vertical or overturned, and strike between N. $10^{\circ} \mathrm{W}$. and N. $20^{\circ} \mathrm{W}$. (fig. 29A). Unconformably overlying these Indianola beds is a sequence of Price River and North Horn strata that dips gently to moderately westward (toward the mountains) (fig. 29A). In this area, thus, two striking angular unconformities break the strati- graphic sequence: an older unconformity between the vertical Indianola and the inclined Price River and North Horn sequence, and a younger unconformity between the upturned Price River and North Horn sequence and the downwarped Flagstaff Limestone that forms the monoclinal slope. Much the same stratigraphic relations can be seen in the Sixmile Canyon ( $\mathrm{F}-4)$ area (along the east side of Sanpete Valley) exposed in a breached sector of the Wasatch monocline.

Along the northeast flank of the Valley Mountains, near Yuba Dam, beds of the North Horn, Flagstaff, Colton, and Green River are downthrown along a high-angle normal fault, against the overturned Indianola strata (figs. 29B, 30). These downthrown units are much disrupted, and most dip at various angles both into and away from the fault. In a few places, where exposures are good, Green River(?) 
beds dip northeastward away from the fault at about $35^{\circ}$. Locally, these Green River(?) beds are overlain by light-gray and pale-red mudstones and shaly siltstones that I correlate with the Colton Formation, and that Prof. J.L. Baer of Brigham Young University has stated are indurated surficial deposits of Pliocene or Pleistocene age (oral commun., 1980). If these varicolored mudstones and siltstones are part of the Colton Formation, the Green River beds must be overturned (first alternative, fig. 30). If the mudstones and siltstones are surficial deposits, as suggested by Prof. Baer, the Green River beds are probably right-side-up (second alternative, fig. 30). Conclusive evidence to resolve this problem was not found. These varicolored beds have also been considered to be part of the Arapien Shale (D.A. Sprinkel, Placid Oil Company, oral commun., 1983).

I interpret these exposures to mean that at some time after deposition of the Crazy Hollow Formation (of Eocene age) the Sevier Bridge Reservoir salt diapir reactivated and bowed up the overlying strata to form a diapiric fold. Subsequently, dissolution of salt caused the crestal part of the fold to fail along high-angle normal faults that developed along the flanks of the fold. As a result, the crest of the fold, consisting of the North Horn to Green River sequence, was downthrown and juxtaposed against the Indianola conglomerate beds that form part of the northwest limb of the fold. This interpretation satisfies both alternatives offered in figure 30; the amount of downthrow determines which part of the folded limb of the fold abuts the Indianola.

Anomalous Depositional. ThinNING

Sedimentary units exposed in and near this breached sector of the Valley Mountains monocline are anomalously thin. So, for example, near the north end of the breached area, in the center of sec. $8, T$. 17 S., R. 1 W., the North Horn Formation is about $38 \mathrm{~m}$ $(125 \mathrm{ft})$ thick, the Flagstaff but $11 \mathrm{~m}(37 \mathrm{ft})$, the Colton only $61 \mathrm{~m}(200 \mathrm{ft})$, and the Green River Formation but $35 \mathrm{~m}$ (115 ft) thick. I interpret this sector as being adjacent to the crest of the fold. As one moves away from the crestal part of the fold, the units increase in thickness rapidly. Thus, some $600 \mathrm{~m}$ $(2,000 \mathrm{ft})$ away, still in the southwest quarter of section 8, the North Horn is in excess of 100 meters thick (its actual thickness is uncertain because its base is concealed beneath debris), the Flagstaff has increased in thickness to $49 \mathrm{~m}$ (162 ft), the Colton is about $83 \mathrm{~m}(270 \mathrm{ft})$ thick, and the Green River is about $95 \mathrm{~m}(310 \mathrm{ft})$ thick. Although exposures are poor and stratigraphic control is uncertain, I believe that the lower-the older-parts of the units pinch out, and only the upper-and younger-parts of the units are preserved.

This depositional thinning, of not one but a sequence of units, must reflect the imperceptible, continuous upward movement of an active diapir. The anomalous thinness of the sedimentary units suggests that this part of the southwest flank of the fold is close to the crest of the concealed fold. The fact that many sedimentary formations thin implies that a dynamic, ancestral topographic high was slowly rising as the sediments that form these formations were being deposited. Were the high not active, but rather a static buried hill, only one or two of the lowermost formations would thin or pinch out against the flanks of the hill. Once the hill was buried, younger formations would pass over the buried hill with their thicknesses unchanged.

Possibly, most of the sediments that now form the basal and middle parts of any one formation were deposited against the flanks of this rising dynamic high; only those sediments that now make up the upper part of that specific formation were able to surmount the rising high. This suggests several alternative interpretations: (1) the diapir rose at different rates during its growth, (2) sedimentation rates differed from time to time, or (3) some combination of the first two alternatives. I favor the third interpretation, in which changes in rate of both diapiric growth and sedimentation are responsible for this thinning of sedimentary units near the crestal part of the fold.

Thus, I attribute both the structural complexity and the depositional thinning to the recurrent reactivation of a major diapiric fold, one that lay directly east of the monocline. I refer to this fold as the Sevier Bridge Reservoir diapiric fold. Presumably, recurrent upward surges of the salt-part of the core of the diapiric fold-repeatedly deformed the Indianola and overlying beds; subsequent removal of the salt from the concealed diapir resulted in differential subsidence of the overlying younger consolidated sedimentary units to form the monocline (Witkind and Page, 1984, p. 147-156). In this interpretation, the bulk of the fold underlies the pediment mantle that fringes the mountains and that extends northeastward toward the southwest shore of the reservoir (fig. 30).

\section{Red Canyon Area (Vallet Mountains)}

Red Canyon (E-2), near the south end of the breached area, trends about N. $70^{\circ}$ E. as a deep, narrow gorge. The mouth of the canyon, in $\mathrm{C}$ sec. 29, T. 17 S., R. 1 W., exposes older rocks whose attitudes 


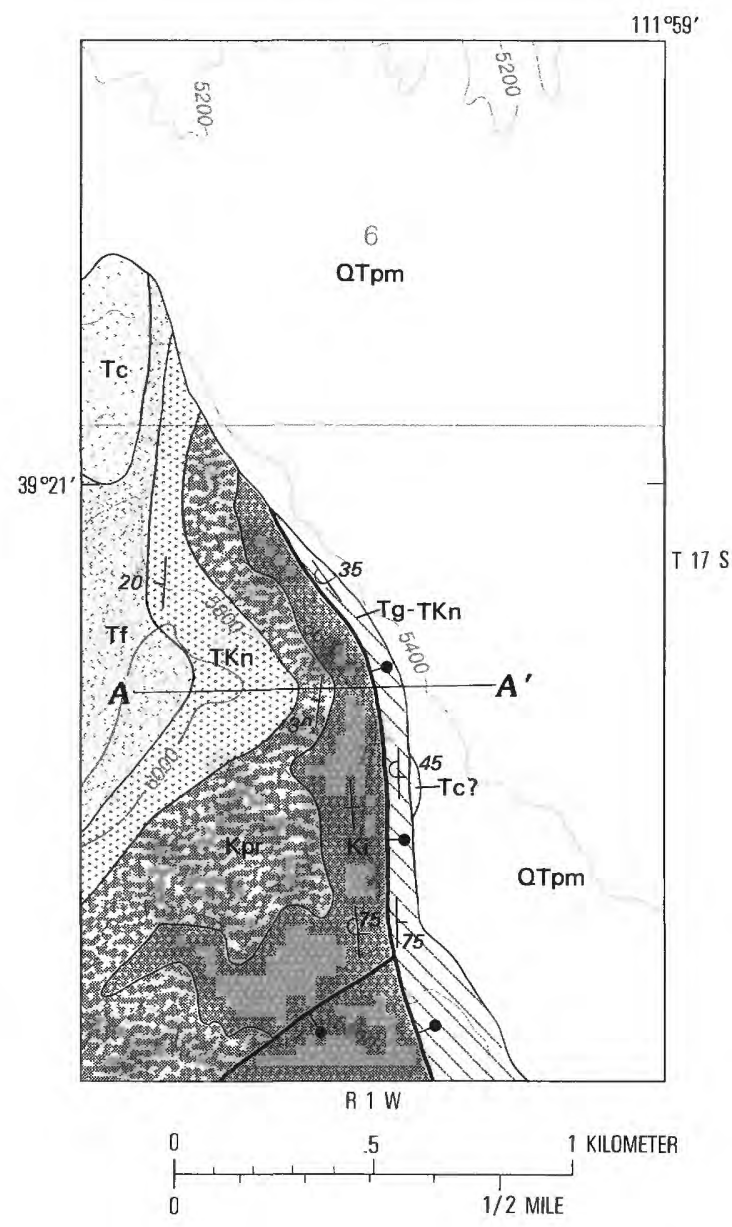

FIGURE 30 (above and facing page).-Geology of northeast flank of Valley Mountains, and diagrammatic sketches suggesting how the southwest flank of the Sevier Bridge Reservoir diapiric fold may have grown and then collapsed during the third diapiric episode (late(?) Oligocene-Pliocene). Base modified from U.S. Geological Survey 1:24,000 Hells Kitchen Canyon SW (1965). Contour interval $200 \mathrm{ft}$.

Two alternative explanations are offered reflecting my uncertainty as to whether downthrown beds east of the northwest-trending fault are overturned or right-side-up. I favor the first alternative (that shown on the geologic map)-that a small patch of light-gray and pale-red mudstones above the Green River Formation is part of the Colton Formation. This implies that the beds east of the fault are overturned.

First alternative - beds are overturned:

I. Late(?) Oligocene intrusive stage. Renewed movement of the northwest-trending Sevier Bridge Reservoir salt diapir forced the mudstones of the Arapien Shale (not shown) to raise and fold back the overlying sedimentary strata and so form a fan-shaped fold. Section is drawn across part of the southwest limb of the fold.

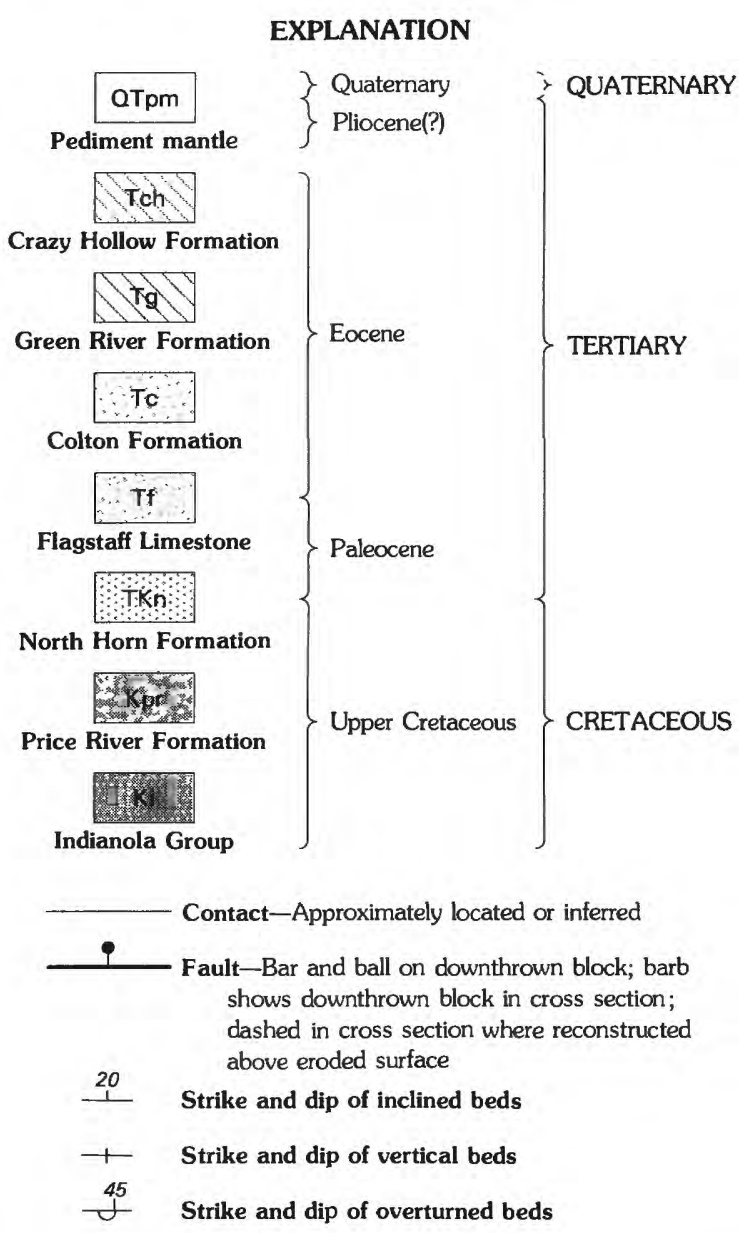

II. Late(?) Oligocene-Pliocene(?) erosional stage. Upon removal of the salt core (not shown) the fold collapsed and the overturned limb of the fold was downthrown along a high-angle fault.

III. Cross section $A-A^{\prime}$. Erosion has removed much of the collapsed fold leaving the overturned, down-thrown beds of the Green River Formation (east of the fault) juxtaposed against the vertical to overturned beds of the Indianola Group (west of the fault).

Second alternative-beds are not overturned:

I. Late(?) Oligocene intrusive stage. It is assumed, in this interpretation, that the crest of the fan-shaped fold, formed by the intrusive action of the Arapien Shale (not shown) is flattened and flexed into an undulatory pattern. Section is drawn across part of the southwest limb of the fold.

II. Late(?) Oligocene-Pliocene(?) erosional stage. As the fold collapsed, due to removal of salt, the crest of the fold was downthrown along a high-angle fault. Amount of stratigraphic throw postulated is greater than that shown in first alternative.

III. Cross section $A-A^{\prime}$. Erosion has removed much of the collapsed fold, leaving the right-side-up, downthrown beds of the Green River Formation (east of the fault) juxtaposed against the vertical to overturned beds of the Indianola Group (west of the fault). 
First alternative-beds are overturned
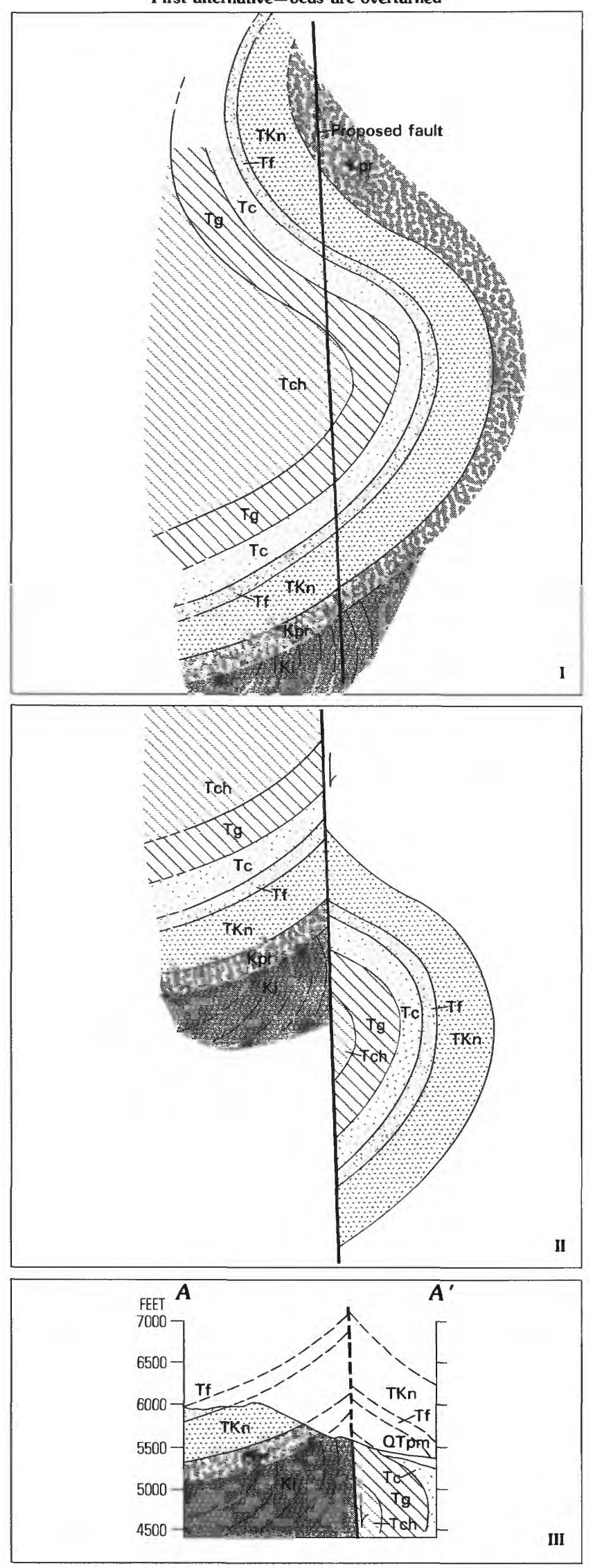

Second alternative-beds are not overturned
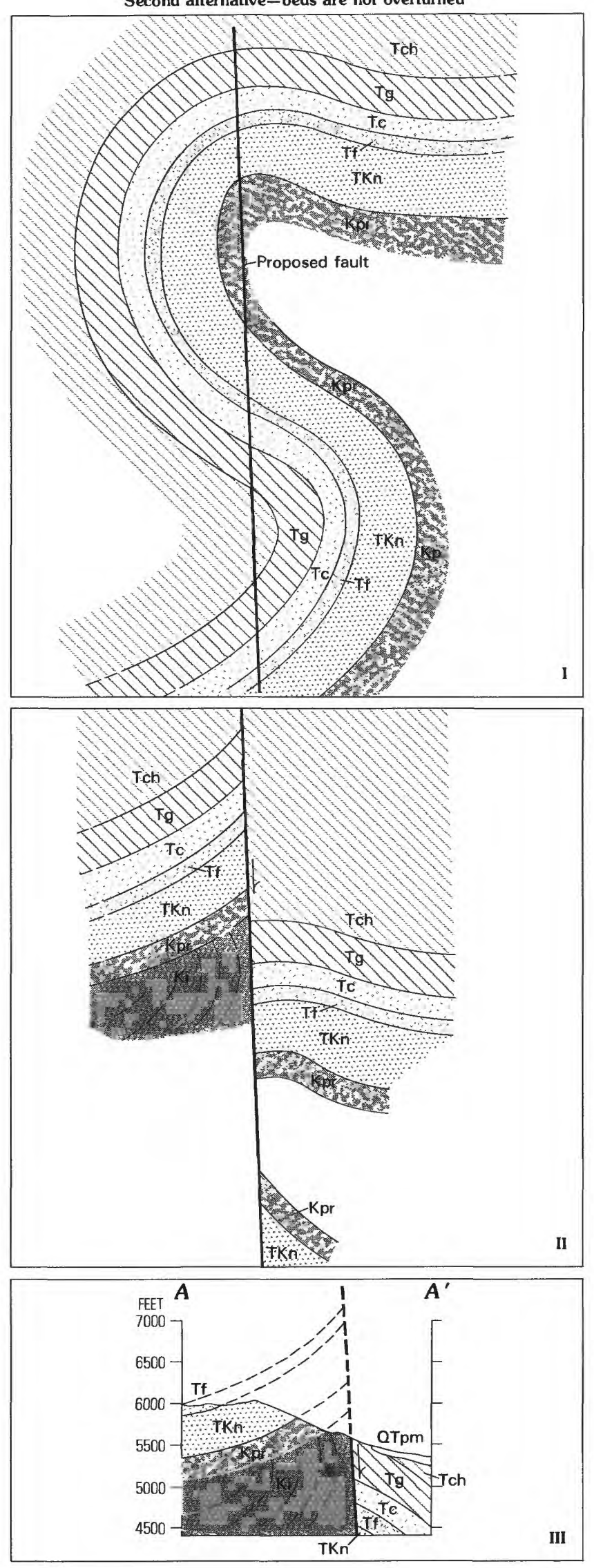


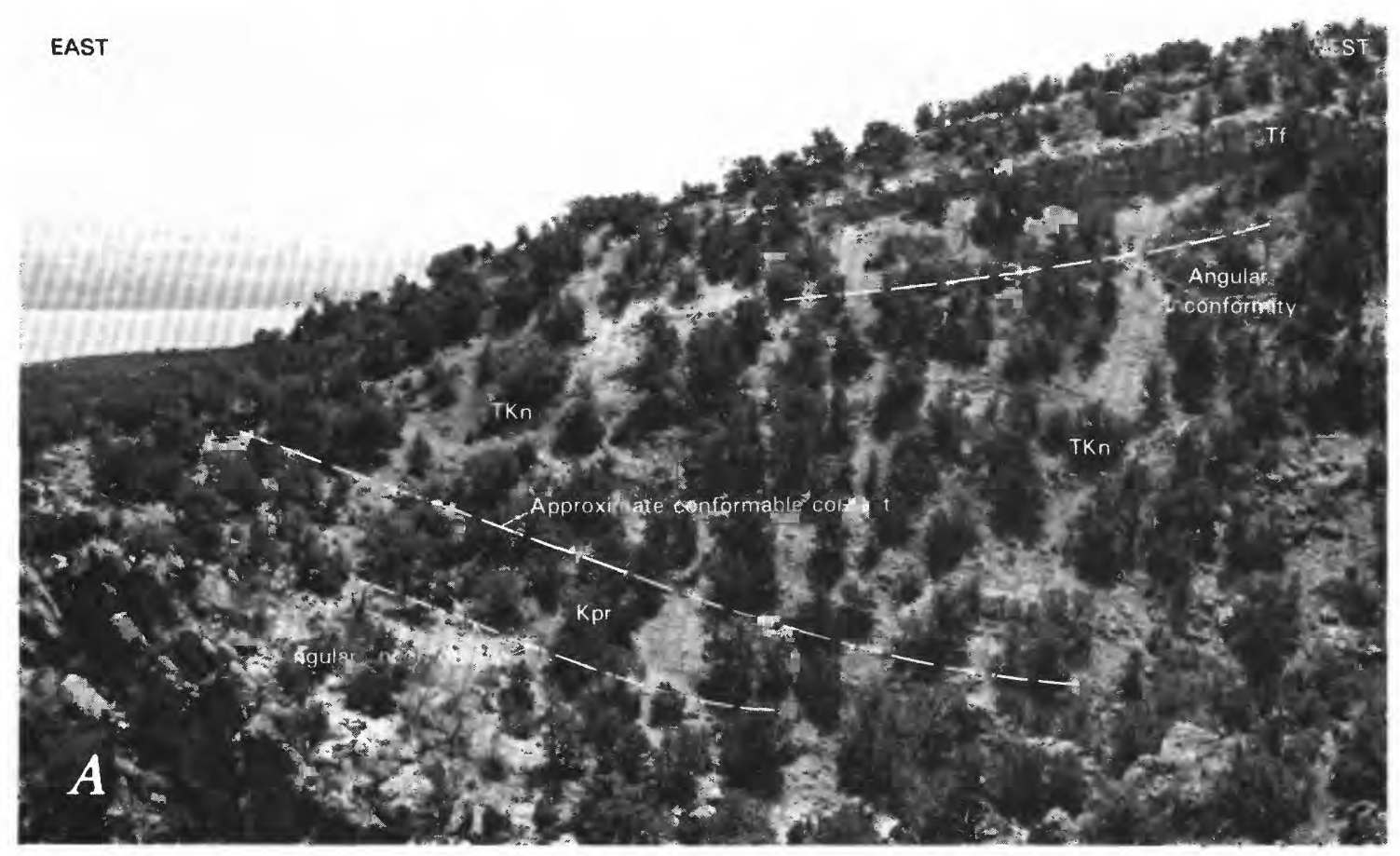

Figure 31 (above and facing page).-Exposures near the mouth of Red Canyon, Valley Mountains. A, View southward of exposures near mouth of Red Canyon. I interpret these exposures to be part of the west flank of the Sevier Bridge Reservoir diapiric fold formed above a salt diapir concealed to east (left) beneath Sevier Valley. $B$, Sketch of view $A$. Indianola strata dip steeply westward (right). These are unconformably overlain by a Price River and North Horn sequence that also dips westward but at much lower dips. The North Horn, in turn, is unconformably overlain by Flagstaff Limestone that dips gently eastward (left) to form part of the Valley Mountains monocline. Long-dashed lines represent approximate attitude of bedding planes. Just to south, beyond area shown in this photograph, the deformed older rocks (Indianola, Price River, and North Horn) are concealed beneath an unbroken mantle of eastward-dipping beds of the Flagstaff Limestone that define the Valley Mountains monocline.

Compare this photograph with the sketch in figure 21, of an area near the mouth of Sixmile Creek canyon along the west flank of the Wasatch Plateau, some $20 \mathrm{~km}(12 \mathrm{mi})$ to the east. In both photograph and sketch, steeply upturned beds of the Indianola Group are unconformably overlain by a Price River and North Horn sequence, which dips toward the mountains. This sequence, in turn, is unconformably overlain by downwarped beds of the Flagstaff Limestone, which dip valleyward-toward the causative salt diapirs. In both localities, the downwarped Flagstaff defines major monoclines. mimic those found elsewhere within the breached sector of the monocline. So, the Indianola beds are near vertical, and these are overlain with profound angular unconformity by Price River beds that dip westward (toward the mountains) at about $15^{\circ}$. North Horn strata overlie the Price River beds conformably, and this westward-dipping Price River and North Horn sequence is truncated by the downwarped eastward-dipping Flagstaff Limestone to form a second, younger angular unconformity (fig. 31).

Here, too, all strata are remarkably thin at the mouth of Red Canyon, near the crest of the postulated Sevier Bridge Reservoir diapiric fold, but they thicken rapidly to the west. The North Horn Formation, for example, is about $15 \mathrm{~m}$ (50 ft) thick near the canyon mouth, but more than $180 \mathrm{~m}(600 \mathrm{ft})$ thick 1.5 $\mathrm{km}(1 \mathrm{mi})$ to the west near the head of Red Canyon.

As shown in figure 32 , I interpret the relations in Red Canyon to reflect three episodes of salt diapirism.

\section{DISCUSSION}

\section{FirST DiaPIRIC EPISODE}

During the first diapiric episode, Indianola Group and older rocks $(\mathrm{KJu})$, were bowed up and warped into a diapiric fold by the upward surge of a salt diapir contained within the Arapien Shale (K(Ja); sketch II of fig. 32). With removal of salt from the core of the fold, the fold collapsed (the collapsed axial part of the fold 


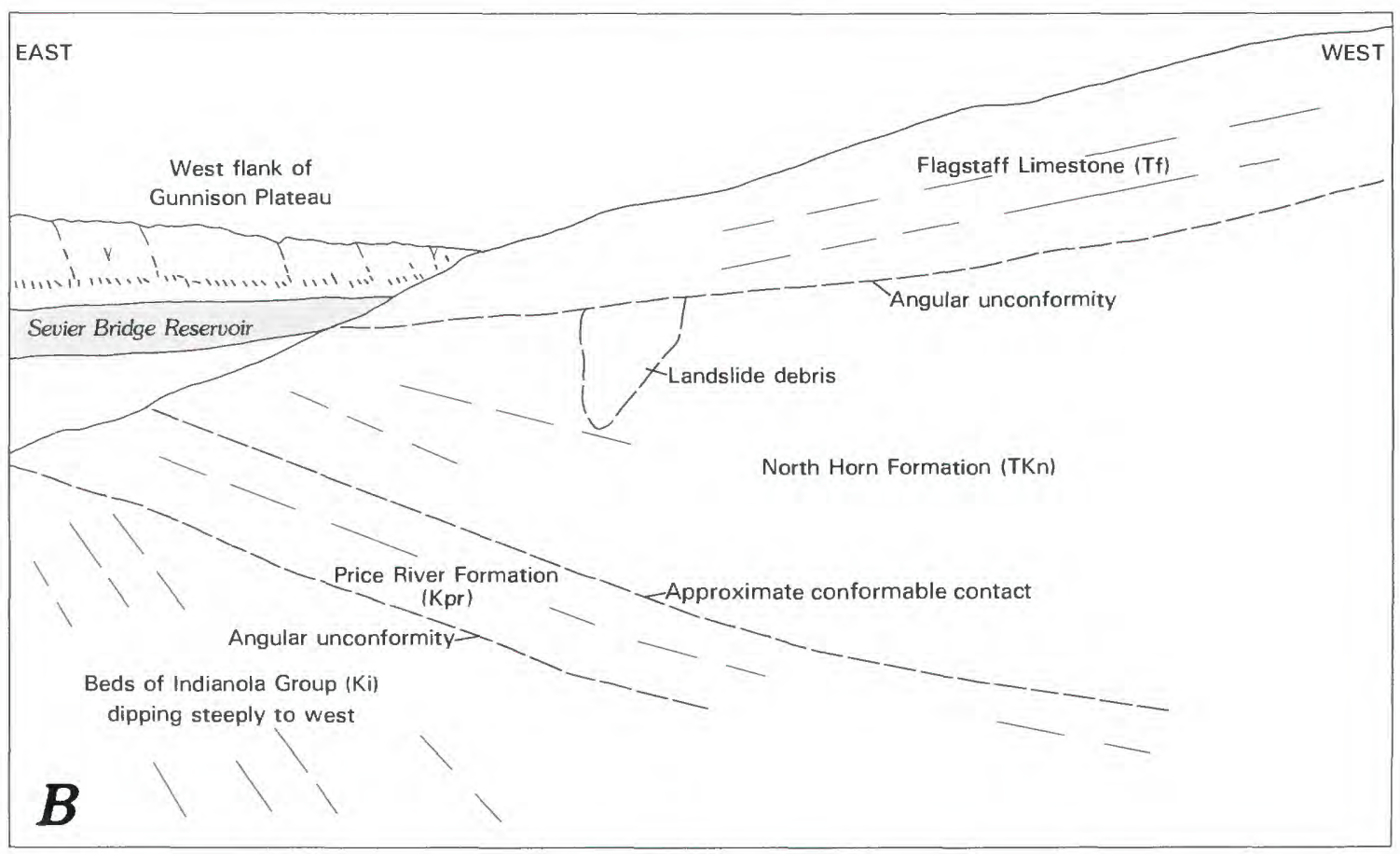

is eastward (left) beyond area covered in this hypothetical sketch), and its remnants were then eroded to a surface of low relief (III of fig. 32). Sediments of the Price River Formation were deposited on this surface, and in time North Horn sediments were conformably deposited on Price River strata (IV of fig. 32).

\section{SECOND Diapiric EPISODF}

A second upward surge of the diapir, marking the beginning of the second diapiric episode, deformed all strata (V of fig. 32). The newly deposited Price River and North Horn sequence was deformed into a diapiric fold, and the previously tilted Indianola beds were tilted to still steeper angles. When this second fold failed, its remnants were eroded to a nearhorizontal surface (VI of fig. 32). Flagstaff (Tf) sediments were deposited across the erosion surface, and in time still younger units (at least Colton (Tc), and Green River ( $\mathrm{Tg}$ ) strata), also accumulated (VII of fig. 32). Subsequently, volcanic units assigned to the Eocene and Oligocene Goldens Ranch Formation (Tgr) mantled the sedimentary stack.

\section{THIRD DIAPIRIC EPISODE}

I am uncertain as to the precise sequence of events that occurred during the third diapiric episode. Two alternatives are feasible; the first suggests that a renewed upward surge of the diapir deformed the near-horizontal Tertiary strata into a new diapiric fold. The exposures in the ancestral Willow Creek (G-3) area (p. 51), where similar Tertiary units, part of the west flank of the Sanpete-Sevier Valley fold, are preserved as vertical and overturned beds, favor this interpretation. Subsequently, at some time after this new diapiric fold was formed, removal of salt from the causative diapir resulted in failure of the fold, and the upturned beds were let down to form an eastward-facing monocline (VIII of fig. 32).

The second alternative, which I tend to favor, suggests that the near-horizontal Tertiary beds, rather than being warped up to form a diapiric fold, subsided, presumably in response to removal of the salt, to form an eastward-facing monocline (VIII of fig. 32).

On the basis of the exposures along the east and northeast flanks of the Valley Mountains, I suggest that the fold trends about N. $55^{\circ} \mathrm{W}$., and is at least $24 \mathrm{~km}$ (15 mi) long. I am uncertain how this fold relates to the Redmond fold (fig. 16); possibly the two are joined to form a compound fold that extends for at least $48 \mathrm{~km}(30 \mathrm{mi})$ from near Redmond, on the south, to near Yuba Dam, on the north. I am also uncertain how far to the northwest this diapir reaches. On the basis of the strike of the overturned to near-vertical Indianola beds exposed at the northwest end of the breached sector of the monocline, the diapir turns to the north, east of Yuba Dam, and 


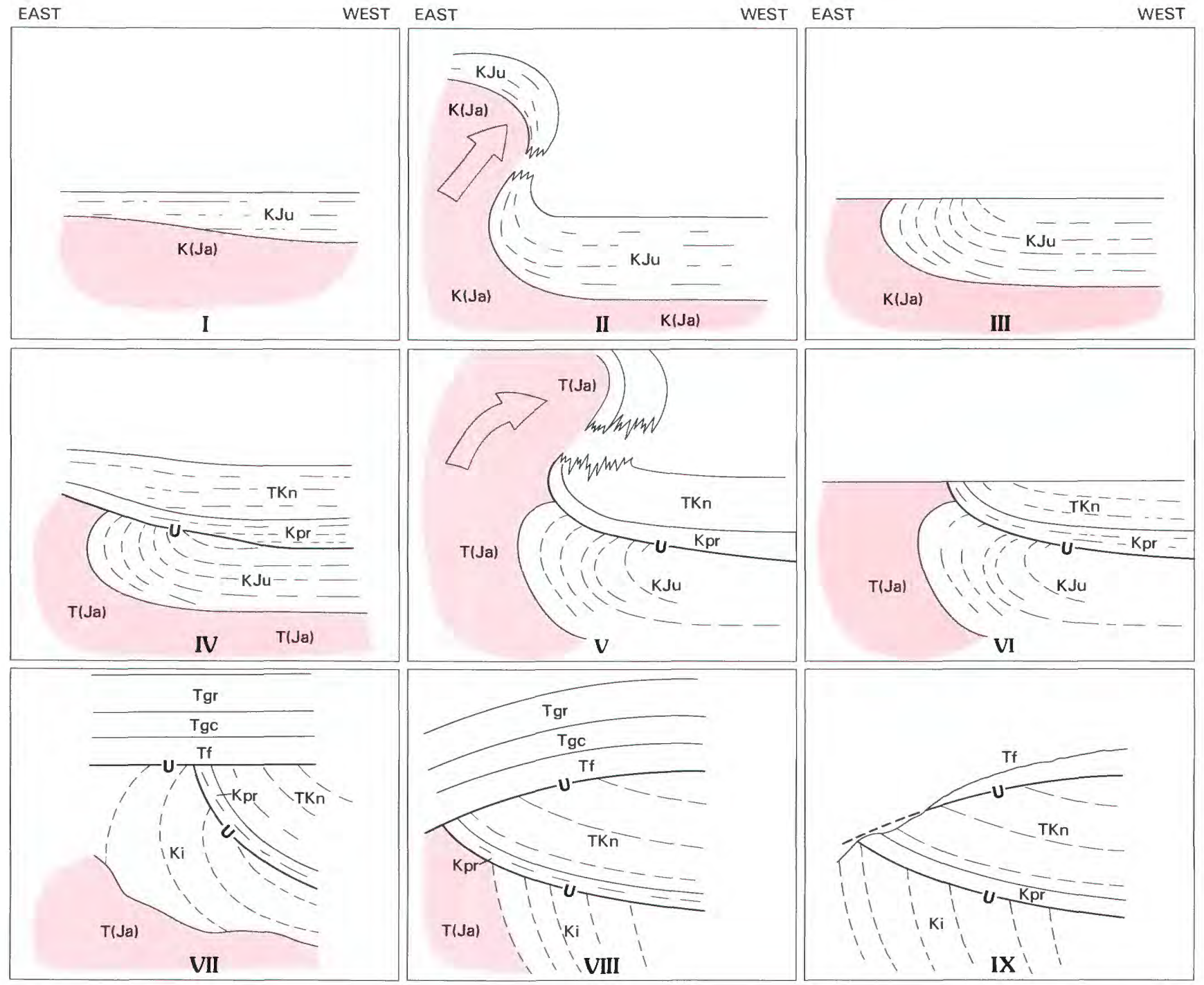

FIGURE 32.-Diagrammatic sketches of the Red Canyon area, Valley Mountains, suggesting how structural relations in Red Canyon formed as a result of two episodes of salt diapirism. View is southward to conform with photograph shown in figure 31. Sketches illustrate west limb of diapiric fold. Causative salt diapir is concealed to east (left) beneath floor of Sevier Valley. Tgr, Goldens Ranch Formation; Tgc, Green River and Colton Formations, undivided; Tf, Flagstaff Limestone; TKn, North Horn Formation; Kpr, Price River Formation; Ki, Indianola Group; KJu, Indianola Group, Cedar Mountain, and Twist Gulch Formations, undivided; J(Ja), $\mathrm{K}(\mathrm{Ja}), \mathrm{T}(\mathrm{Ja})$, emplacement ages of the Middle Jurassic Arapien Shale (see text for discussion). $U$, angular unconformity. I. Twist Gulch, Cedar Mountain, and Indianola strata (KJu) were deposited along the west flank of a slowly rising diapiric fold. All units thin toward the crest of the fold (left, not shown) in response to the slow upward movement of the salt diapir. II. An upward surge of the salt diapir bowed up the Jurassic and Cretaceous units (KJu) to form a fan-shaped fold.

III. As a result of removal of salt the fold collapsed; subsequent erosion formed a surface of low relief across the fold's remnants.
IV. Price River sediments (Kpr) were deposited on the newly formed surface, and in time these were conformably overlain by North Horn sediments (TKn). Both formations thinned toward the crest of the fold in response to the slowly rising salt diapir.

V. A renewed upward surge of the salt diapir warped up all overlying strata to form a new fan-shaped diapiric fold that occupied the same site and had the same trend as the previous fold.

VI. Collapse of the fold and subsequent erosion reduced the area to a surface of low relief.

VII. Flagstaff Limestone sediments were deposited across this surface, and these in turn were overlain by successively younger units-the Green River and Colton (Tgc), and Goldens Ranch (Tgr) Formations. All units thin toward the crest of the fold in response to the slowly rising salt diapir.

VIII. Removal of salt resulted in subsidence of overlying units to form the eastward-facing Valley Mountains monocline.

IX. Erosion removed most of the younger units, and locally breached the Flagstaff Limestone (Tf), exposing the complex structural sequence imposed on the older rocks. 
extends into a broad flat known as The Washboard. The $60 \mathrm{~m}(200 \mathrm{ft})$ of intermixed salt and mudstone cut by Placid Oil Company's Monroe 13-7 well (sec. 13, T. 16 S., R. 2 W.) (fig. 9), which was sited north of the Sevier Bridge Reservoir and northeast of Yuba Dam, essentially in The Washboard, implies that the well penetrated part of the diapir.

I believe that the Arapien Shale is concealed beneath both the reservoir and the surficial deposits that floor this sector of Sevier Valley.

\section{LEVAN DIAPIRIC FOLD}

The Arapien Shale crops out extensively along the west flank and around the north end of the Gunnison Plateau (D-3) (fig. 8). Along the west flank of the plateau, east of Levan (C-3), consolidated sedimentary strata overlie Arapien exposures. Those sedimentary beds that overlie the east edge of the Arapien exposures dip eastward, those that overlie the west edge dip westward. I interpret these relations to mean that the Arapien exposures are part of the core of the Levan diapiric fold (fig. 16, 3), and the overlying sedimentary strata the eroded flanks of that same fold.

On the basis of Arapien exposures, the core of the Levan fold extends about N. $15^{\circ} \mathrm{E}$. for some $40 \mathrm{~km}$ (25 mi) from Little Salt Creek (D-3) on the south to Salt Creek (B-3) on the north. I believe, however, that the diapiric core is much longer, extending perhaps as far south as the south end of the Gunnison Plateau where it may join the Sevier Bridge Reservoir diapir. If so, the diapir is about $50 \mathrm{~km}(32 \mathrm{mi})$ long. I project the diapir to the south chiefly on the basis of the westward-facing West Gunnison monocline, perceiving this monocline to have been formed as the result of the removal of salt from the causative salt diapir, in much the same fashion as the Wasatch and Valley Mountains monoclines.

At the north end of the diapiric fold-near Salt Creek - the fold seemingly divides to form three branches (fig. 16). The western fold, for which I retain the name Levan fold, extends northward beyond Salt Creek, and passes below and deforms the upper plate of the Charleston-Nebo thrust fault (Witkind, 1983, p. 51-54). The eastern fold, the Pole Creek diapiric fold (fig. 16, 12), extends northeastward into Salt Creek where it seemingly deforms the north end of the Gunnison Plateau, as well as those strata that lap onto the eastern margin of the Charleston-Nebo thrust plate. The middle fold, the Footes Canyon (B-3) fold (fig. 16, 13), may extend northward beneath the Charleston-Nebo thrust plate, and deform part of that plate.
Gravity data (fig. 52) show part of a deep linear low that seemingly follows the centerline of Juab Valley. This low may reflect either a thick valley fill of surficial material or Arapien mudstone. If the low does indeed stem from Arapien mudstone, one would have to assume that still another diapiric fold underlies Juab Valley (Witkind and Marvin, 1989). The crest of such a fold would be about $8 \mathrm{~km}(5 \mathrm{mi})$ west of the Levan fold.

A series of unusual geologic relations exposed along the flanks of the diapiric fold demonstrate the upward movement of the Levan diapir. Of these exposures, perhaps the most striking is along Pigeon Creek (C-3).

\section{PIGEON CREEK AREA}

East of Levan (C-3), in Pigeon Creek along the west flank of the Gunnison Plateau (fig. 2), Arapien mudstones that form the core of the Levan diapiric fold have intruded and warped an overturned anticline. Pigeon Creek, flowing westward, cuts through a northward-trending anticline, which is formed, in part, by the thin, dark-gray beds of the Twin Creek Limestone. A test well, the Levan Unit, in the NE1/4 NW $1 / 4$ sec. 17 , T. 15 S., R. 1 E., drilled by Standard Oil of California, demonstrated that the fold is overturned (Ritzma, 1972, p. 78).

Near the mouth of Pigeon Creek the limestone beds that form the west flank of the fold dip gently to moderately westward (fig. 33). Eastward, toward the crest of the fold, the beds become nearly horizontal, and then beyond the crest, the beds dip eastward. Near the center of the fold, red mudstone beds of the Arapien Shale and several gypsum beds are intercalated in the thin limestone beds of the Twin Creek. Locally, these lenses and seams of gypsum separate the limestone beds to form elongate, near-horizontal pods that conform to the bedding. Elsewhere, the gypsum forms vertical pods that cut across the bedding. These relations imply that the lenses and seams of gypsum are intrusive, and not interbedded.

At the east edge of the fold, the eastward-dipping beds flex up sharply and dip westward (fig. 34A), then become vertical, and finally are overturned (fig. $34 B, C$ ). These overturned beds abut Arapien mudstone beds that form the west flank of the diapiric core of the Levan fold (fig. 16). Locally, these beds of the Arapien Shale overlie the overturned Twin Creek beds.

I interpret these geologic relations to mean that the Levan diapiric fold invaded and warped this overturned fold long after the fold was emplaced. The 

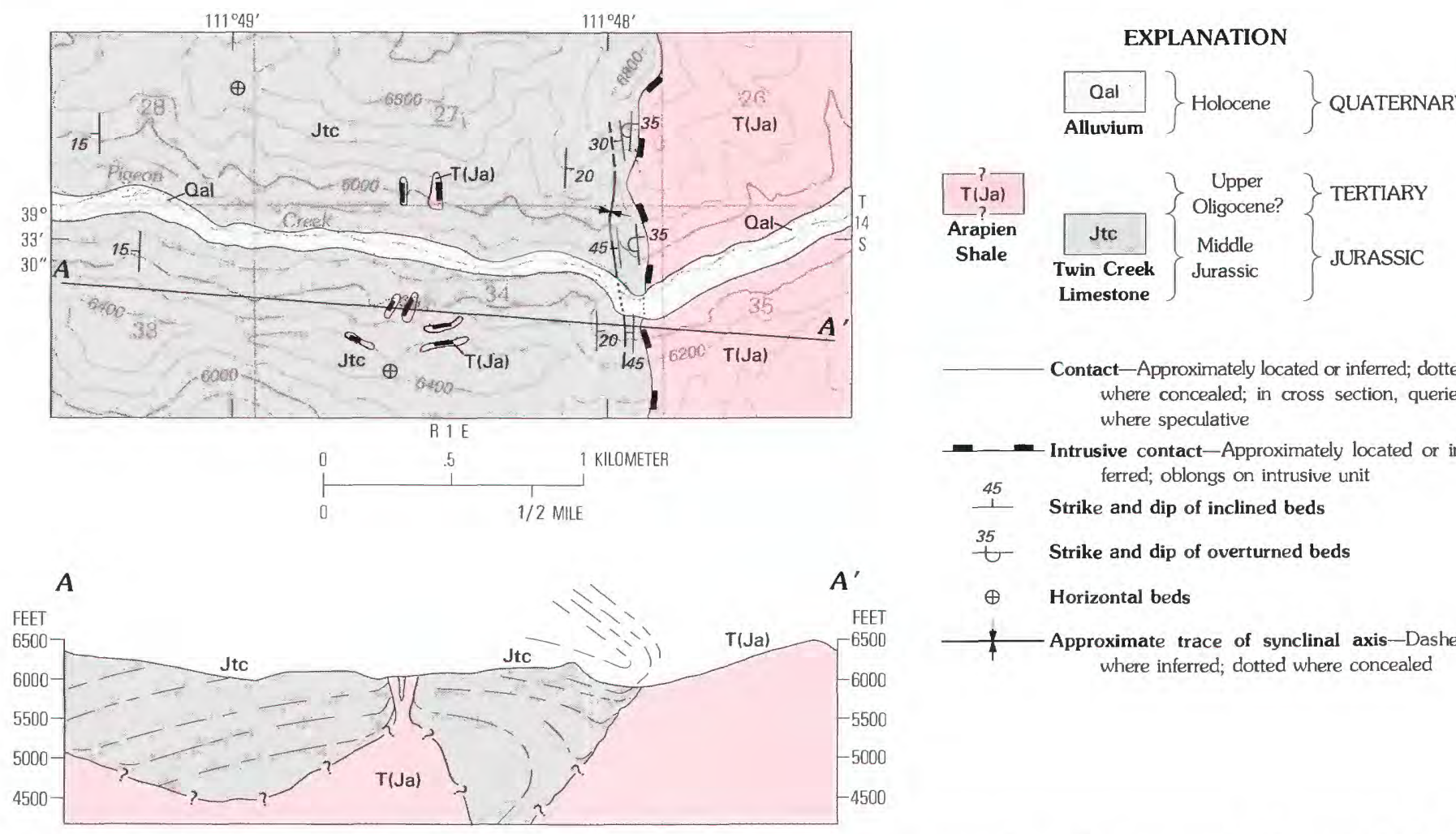

\section{EXPLANATION}

$\left.\begin{array}{c|c|}\hline \text { Qal } \\ \text { Alluvium }\end{array}\right\}$ Holocene $\}$ QUATERNARY

Limestone $\int$ Jus
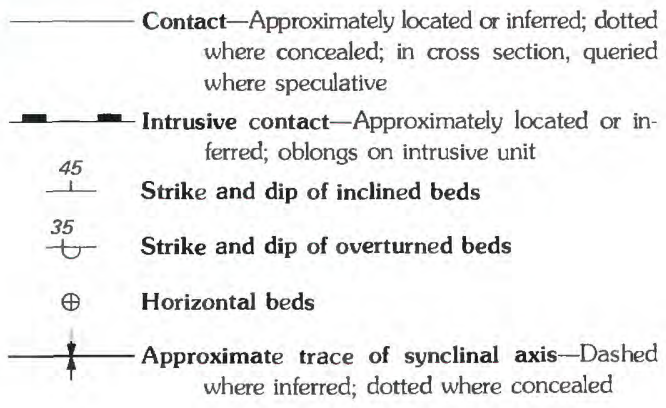

FIGURE 33.-Geology across the Pigeon Creek area showing relations between an overturned anticline (composed of limestone beds of the Twin Creek Limestone) and intrusive mudstone and gypsum beds of the Arapien Shale. As the Arapien Shale deforms volcanic units of middle Tertiary age in this general area, I suspect that the time of major movement of the Arapien is middle Tertiary, hence the symbol "T(Ja)". Base modified from U.S. Geological Survey 1:24,000 Levan (1983). Contour interval $200 \mathrm{ft}$.

intruding and deforming nature of the Arapien Shale is shown by the intercalated and vertical beds and pods of gypsum and mudstone in the center of the anticline. The eastward-dipping Twin Creek beds, along the east flank of the anticline, that were warped into westward dips, overturned, and eventually torn off, demonstrate the upward thrust of the Arapien (cross section $A-A^{\prime}$, fig. 33 ).

I believe that this overturned anticline is an erosional remnant of the much larger overturned Charleston-Nebo thrust plate so well exposed some $20 \mathrm{~km}$ (12 mi) to the north near Nephi (B-3).

\section{GARDNER CANYON-RED CANYON AREA}

The deformation of the Charleston-Nebo thrust plate by the Levan fold is best seen in Gardner and Red Canyons (B-3), a rugged area about $4 \mathrm{~km}(2.5$ mi) northeast of Nephi (fig. 2).

The Gardner Canyon-Red Canyon area consists of two deep canyons cut into the west flank of the southern Wasatch Range (fig. 35). Both canyons trend southwest and expose, in a series of outcrops, the relations between the Arapien Shale and various sedimentary units that form part of the CharlestonNebo thrust plate. In this sector of the southern Wasatch Range, the thrust plate appears as the lower limb of an overturned, almost recumbent anticline. This lower limb consists of strata that range in age from Jurassic (Twin Creek Limestone) to Permian and Pennsylvanian (Oquirrh Group). All units are overturned.

\section{Gardner Canyon Area}

In Gardner Canyon (B-3), which is about $1.3 \mathrm{~km}$ $(0.8 \mathrm{mi})$ north of Red Canyon, the overturned beds of the thrust plate are disrupted by a small mass of intensely contorted Arapien mudstones. These mudstone beds, exposed along the lower flanks of the valley walls, are locally overlain by beds of light-gray to gray thin limestone, part of the Twin Creek Limestone, that, in striking contrast to the overturned beds that form the thrust plate, are right-side-up. These Twin Creek beds form two distinct exposures.

The southern Twin Creek exposure, about $0.8 \mathrm{~km}$ $(0.5 \mathrm{mi})$ wide, is encircled by Arapien mudstones, and 

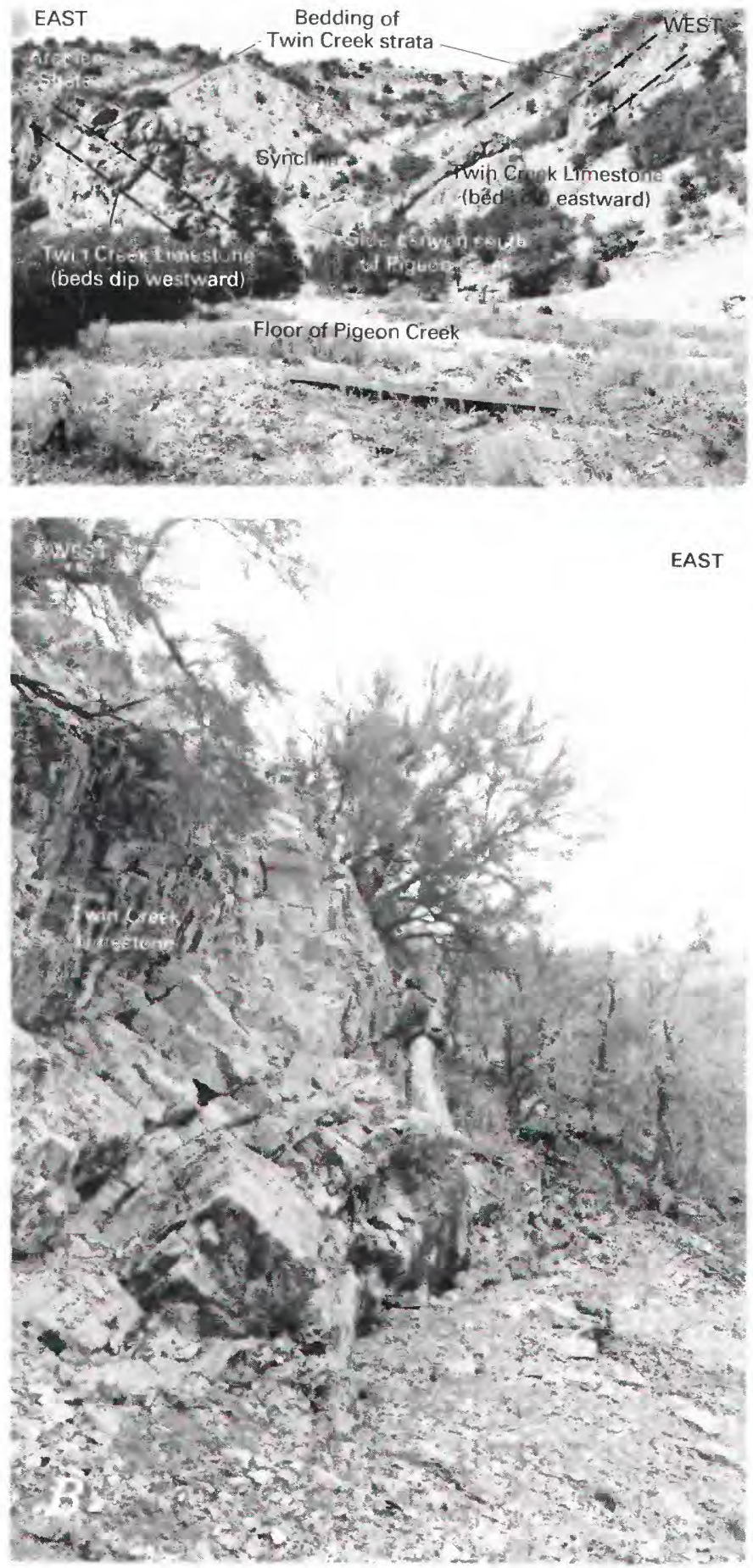

appears as a northeast-trending syncline (fig. 35). In detail, those limestone beds along the south edge dip northward at about $40^{\circ}$, but in one place where they directly abut the Arapien mudstones, they are overturned and form a tight anticline (fig. 36) that is much like the overturned fold formed along the east margin of the north-trending anticline in Pigeon Creek (C-3). As these north-dipping beds are traced northward, they lessen in dip and then reverse dip

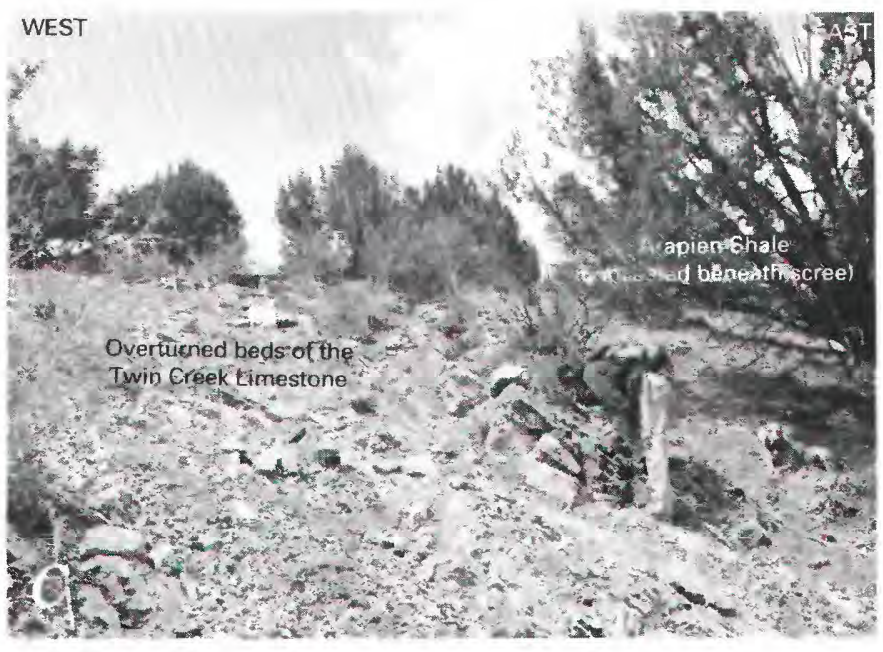

Figure 34.-Folding of the Twin Creek Limestone in Pigeon Creek as a result of upward movement of the Arapien Shale. A, View of south canyon wall of Pigeon Creek showing east limb (right side of photo) of north-trending anticline exposed along Pigeon Creek. Twin Creek Limestone dips eastward as part of the east limb of the anticline. At their juncture with the Arapien Shale the beds are warped up and dip westward (left side of photograph). A small, distinct syncline, exposed in a side canyon south of Pigeon Creek, marks abrupt reversal of dips. On the opposite (north) canyon wall, outcrops (views $B$ and $C$ ) demonstrate that the warped-up Twin Creek Limestone becomes vertical and is eventually overturned. $B$. View of north canyon wall of Pigeon Creek showing the warped-up Twin Creek Limestone beds exposed along east flank of the north-trending anticline. Vertical beds of Twin Creek Limestone are overturned at top of the small knoll (above head of geologist) but the overturned beds are concealed behind the trees. View $C$ shows relations on top of knoll. The Arapien Shale crops out beneath scree-covered slope directly behind geologist. $C$, As the vertical beds shown in $B$ are traced onto crest of the knoll they are overturned, become almost recumbent and dip about $30^{\circ}$ eastward. The Arapien Shale crops out on the scree-covered slope on which dog lies.

Figure 35 (following pages)-Geology of Gardner Canyon-Red Canyon-Birch Creek area showing relations between the upper plate of the Charleston-Nebo thrust fault (lower limb of an overturned anticline) and the north end of the Levan diapiric fold. Base modified from U.S. Geological Survey 1:24,000 Mona (1979) and Nephi (1983). Contour interval $200 \mathrm{ft}$.

As interpreted, the Arapien Shale ( $\mathrm{T}(\mathrm{Ja})$ ) intruded and bowed up the upper plate of the thrust fault. Probably the Arapien Shale simultaneously bowed up the edge of the thrust plate as well as beds of the Indianola(?) Group (Ki) that are exposed east of the Rees Flat area.

The upper plate was further deformed, in the Gardner Creek-Birch Creek area, when an intrusive mass of the Arapien Shale forced up a small wedge of the Navajo Sandstone (Jn) and the overlying Twin Creek Limestone (Jtc) and juxtaposed these units against overturned beds of the Permian and Pennsylvanian Oquirrh Group (PPo). As the Navajo and Twin Creek are right-side-up, they probably represent part of the lower plate of the Charleston-Nebo thrust.

I am uncertain when this uplift of the Navajo-Twin Creek wedge occurred, but possibly both intrusive events-the deformation of the thrust plate and the uplift of the wedgeoccurred at the same time, during the second diapiric episode. 


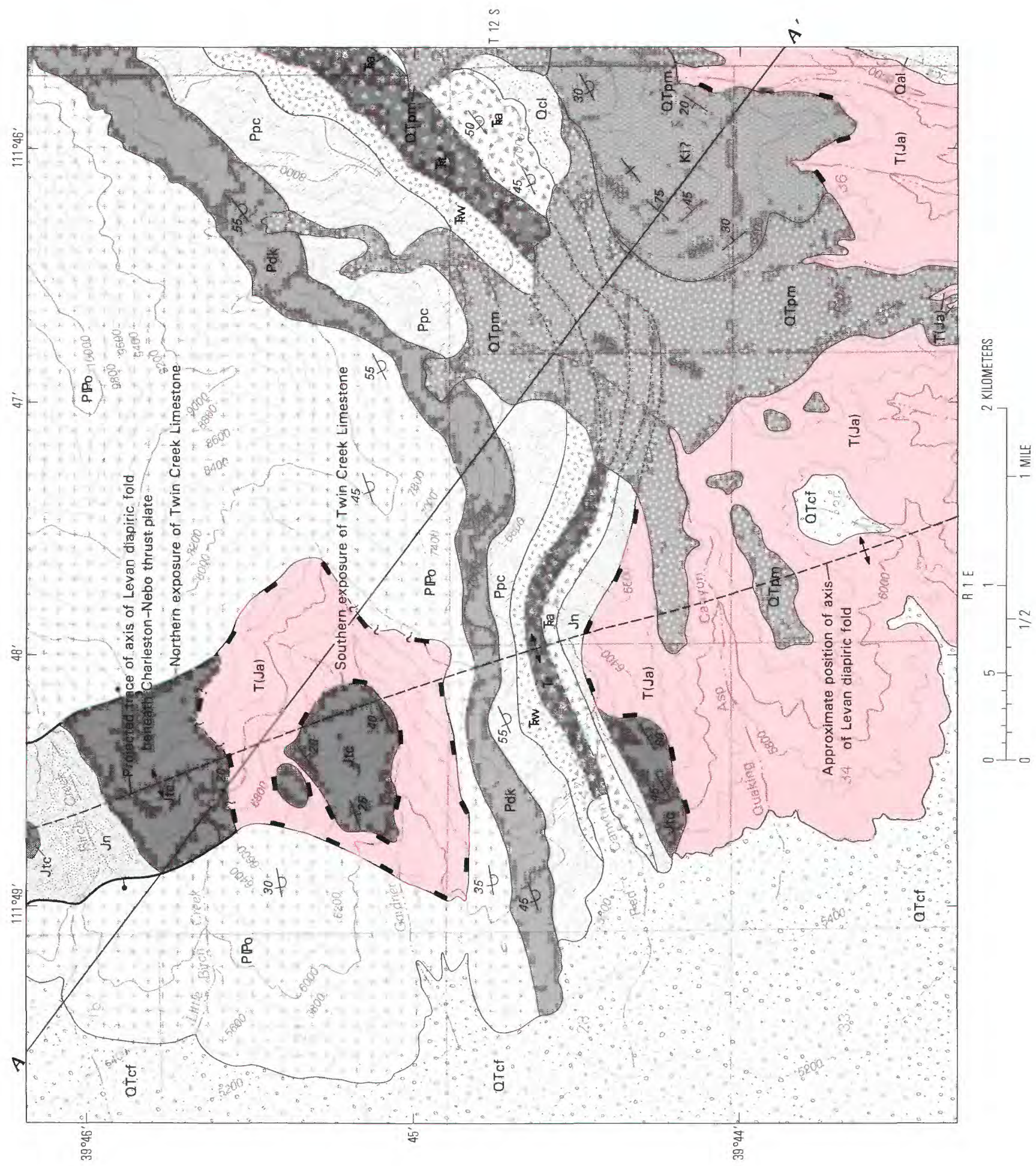



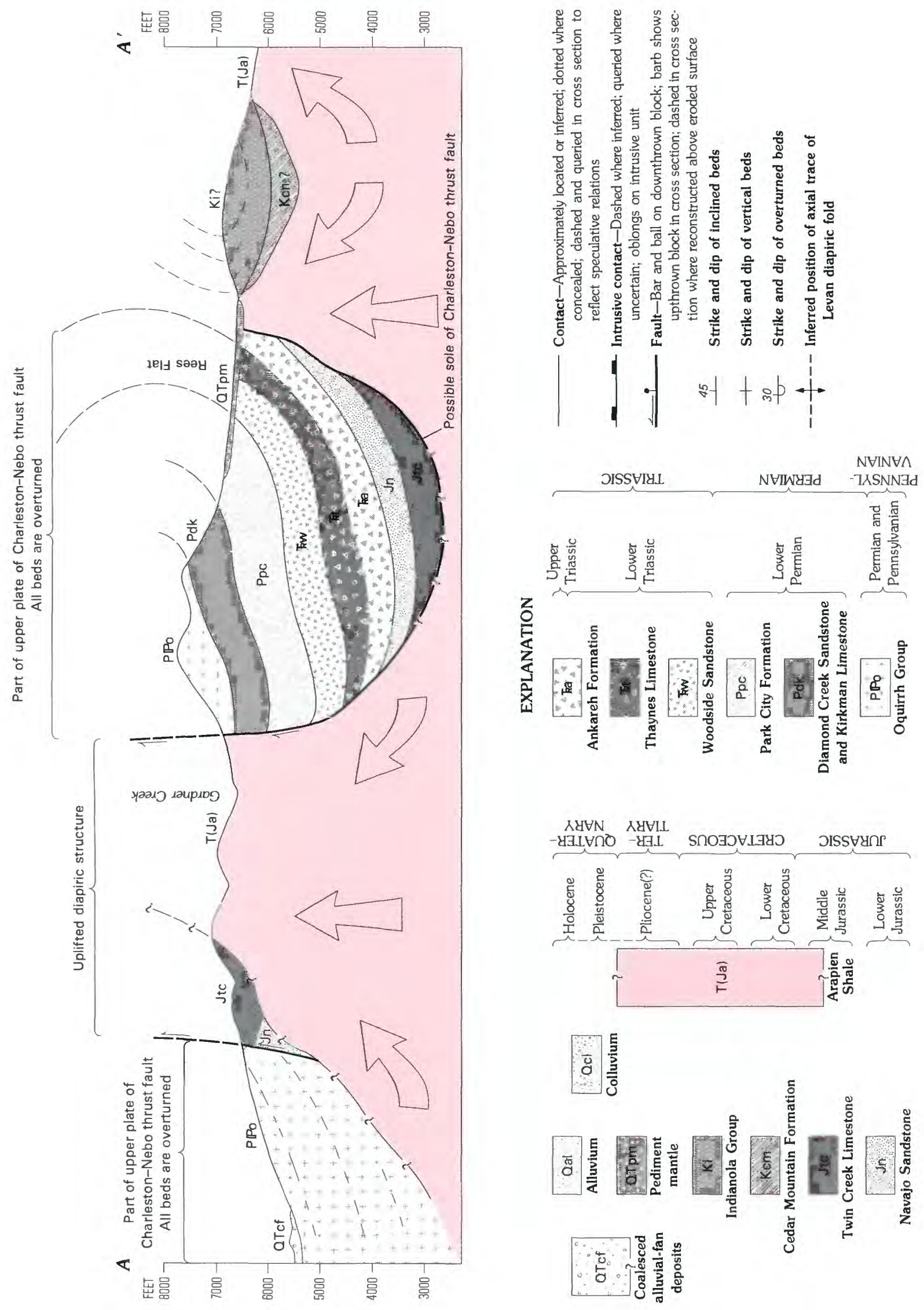
and are inclined southward at about $25^{\circ}$ where they abut the Arapien mudstones.

The northern Twin Creek exposure, also about 0.8 $\mathrm{km}(0.5 \mathrm{mi})$ wide, is separated from the southern exposure by about $300 \mathrm{~m}(1,000 \mathrm{ft})$ of Arapien mudstone. This northern exposure is subparallel to and about $1 \mathrm{~km}(0.7 \mathrm{mi})$ east of the mountain front (fig. 35). Both the east and west edges of this Twin Creek exposure are in near-vertical fault contact with overturned, northwest-dipping beds of the Oquirrh Group of Permian and Pennsylvanian age. At the north end of this narrow Twin Creek exposure, Birch Creek has eut a deep, narrow canyon and exposed the underlying Navajo Sandstone. This band of Navajo and Twin Creek strata extends for more than $1 \mathrm{~km}(0.75 \mathrm{mi})$ north of Birch Creek before it disappears, near Ingram Canyon, beneath Paleozoic

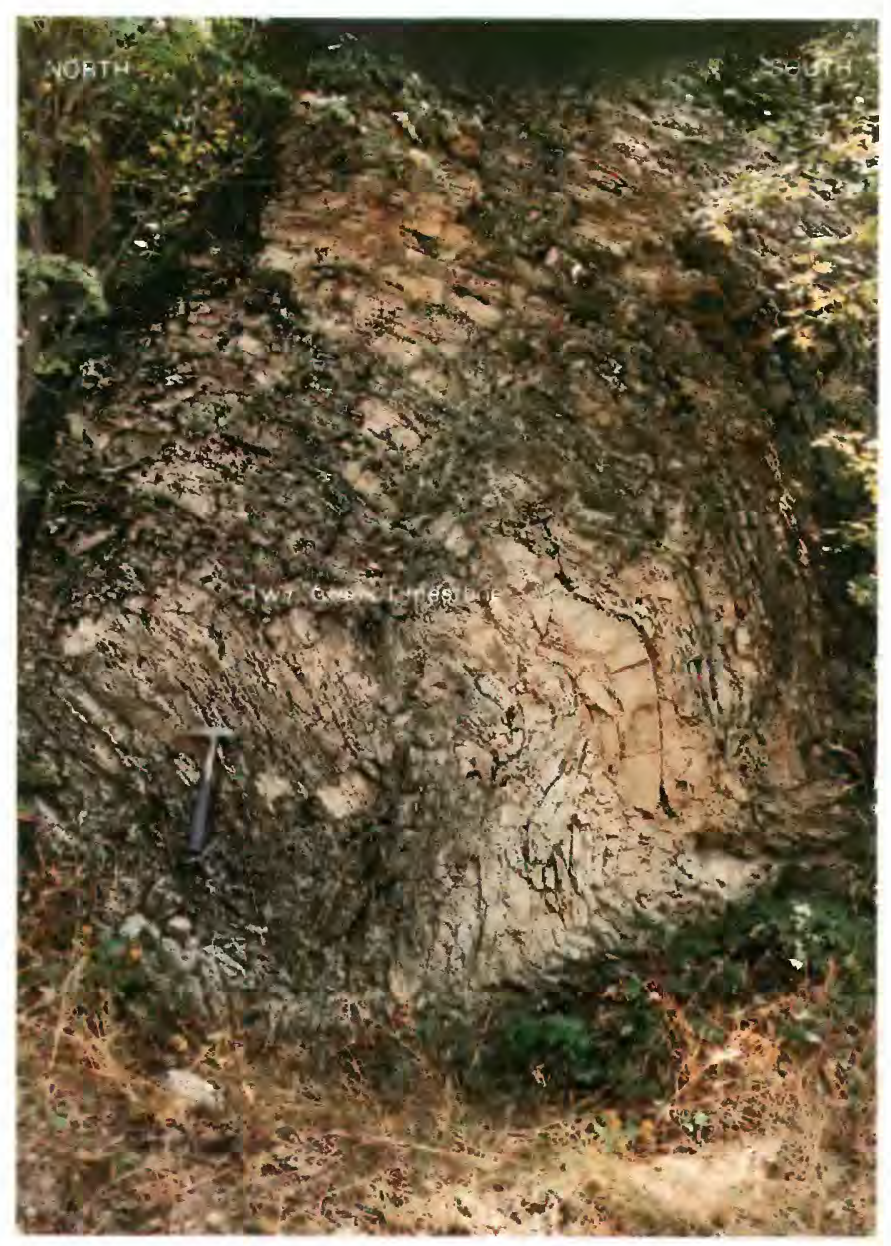

FIGURE 36.--Overturned beds of the Twin Creek Limestone as exposed in Gardner Canyon. The Arapien Shale crops out just to the right of beds exposed in this photograph. I believe this fold, much like the overturned fold in Pigeon Creek (fig. 34), is the result of intrusion and upwarp by the Arapien Shale. strata that form part of the Charleston-Nebo thrust plate.

The Arapien mudstones exposed in Gardner Canyon appear to be a northward outcrop of similar Arapien units exposed to the south near Red Canyon, and I interpret both Arapien exposures to be part of the diapiric core of the Levan fold.

Although these geologic relations between the Arapien, Twin Creek, and the Oquirrh may represent a window in a folded thrust sheet, much as interpreted by Black (1965, cross section $C-C^{\prime}$ ), I believe that the steep to near-vertical contacts between the Arapien Shale and the Oquirrh Group, and between the Twin Creek Limestone and the Oquirrh, are more reasonably explained by vertical uplift. Although it is possible that this vertical compression was induced during southeastward-directed emplacement of the Charleston-Nebo thrust plate (Black, 1965, p. 80), the lack of uniformity in the axial trends of the folds formed in the contorted Arapien strata suggests that the compression, more likely, stems from the later, upward vertical movement of the Arapien Shale as it was forced upward by its salt component. Consequently, as suggested by cross section $A-A^{\prime}$, figure 35 , I interpret the Arapien strata to be a plug of the Levan diapiric core that lifted, tilted, and juxtaposed this band of Navajo Sandstone-Twin Creek Limestone against overturned Oquirrh strata, part of the main body of the Charleston-Nebo thrust plate. During the upward movement, the Arapien broke the Navajo-Twin Creek mass into two parts, and folded the southern part into a syncline.

As the Navajo Sandstone and the overlying Twin Creek Limestone are right-side-up and in a normal stratigraphic sequence, rather than being overturned as one might expect if they were a part of the overturned beds that form the upper plate, this upthrust mass is probably part of the lower plate of the Charleston-Nebo thrust fault.

Exposures to the east, near Rees Flat (fig. 35), support the concept that the Arapien Shale has intruded and deformed part of the thrust sheet. As the contact between the overturned beds of the thrust plate and the Arapien mudstones is traced eastward up Red Canyon, the contact eventually disappears beneath a pediment mantle of sand and gravel that floors Rees Flat. The east edge of Rees Flat is bounded, on the north, by overturned rocks of the thrust plate, and on the south, by a small hill formed by upturned conglomerate and sandstone beds that have been warped to form an irregular-shaped basin. The Arapien Shale underlies these conglomerate beds along the east and south edges of the basin; because of the pediment mantle (fig. 35), I have not identified 
the unit underlying the conglomerates along the west and north edges of the basin. The basin, although of somewhat irregular shape, is about $1.2 \mathrm{~km}(3 / 4 \mathrm{mi})$ in diameter. The conglomerate beds nearest the thrust plate are vertical or overturned; those along the east flank of the basin dip westward, even as those along the south flank dip northward. In the past, Johnson (1959) assigned the reddish-brown conglomerate and sandstone beds that form the basin to the Price River Formation; subsequently, Black (1965) assigned them to the Indianola Group; and still later I (1983) also assigned them to the Indianola Group.

Biek (1988b), however, has decided that the beds in question are part of the Cedar Mountain Formation. Whether the beds are Indianola or Cedar Mountain stems from uncertainty as to just what units should be included in the Cedar Mountain Formation. Witkind, Standlee, and Maley (1986, p. 4), studying exposures in the Red Rocks area, along the southeast flank of the Gunnison Plateau, included two units in the Cedar Mountain Formation: “***an upper unit that consists primarily of beds of reddish-brown coarse conglomerate, and a lower unit that consists of variegated mudstone $* * *$." As the upper conglomeratic unit is much like the conglomerate beds that make up the bulk of the Indianola Group, the two units are difficult to separate. Co-authors Witkind and Maley (in Witkind, Standlee, and Maley, 1986, p. 5), influenced by the fact that the change from mudstone to conglomerate is an easily recognizable contact, proposed that the "****upper unit be provisionally assigned to the undivided Indianola Group." For mapping purposes, therefore, I have considered the upper conglomeratic unit to be part of the Indianola. Biek (1988b), however, included both the conglomerate and mudstone units in his Cedar Mountain Formation. In figure 35 I show the beds as Indianola but add a query to reflect my uncertainty as to the correct assignment of these conglomerate beds.

I suspect that the basin is encircled and underlain by the Arapien Shale with much of the Arapien concealed beneath the surficial deposits that form the floor of Rees Flat (Witkind and Weiss, 1991). It is possible that some of the deformation of the north end of the basin is attributable to the southeastwarddirected movement of the Charleston-Nebo thrust plate, with some deformation due to the upward thrust of the Arapien. The vertical to overturned beds that mark the north edge of the basin imply that a strip of Arapien, confined between the edge of the thrust plate and the once near-horizontal Indianola(?) beds, pushed up and bowed back the Indianola(?) beds. The westward dip of the beds that form the east edge of the basin probably reflect the west flank of the Footes Canyon diapiric fold, one of the three folds formed when the Levan fold trifurcated.

If this deformation of the basin is due, in part, to vertical uplift of the Arapien Shale as well as to eastward movement of the thrust plate (Black, 1965, p. 80), the mudstones of the Arapien not only underlie the basin but also underlie the toe of the thrust plate. By their upward movement the Arapien mudstones may have bowed up part of the plate even as they deformed the basin (east half of cross section $A-A^{\prime}$, fig. 35).

Red Canyon Area (Southern Wasatch Range)

Basal thrust plate strata are exposed in and near Red Canyon (B-3) where overturned beds of the Twin Creek Limestone, part of the thrust plate, rest on contorted mudstones of the Arapien Shale. These mudstones and their contained evaporites are severely deformed and give every sign of intense compression. Near the mouth of Red Canyon, the Twin Creek beds that directly overlie the Arapien Shale mudstones are overturned and dip northwestward $\left(45^{\circ}\right)$, thus conforming to the attitude of the overlying (stratigraphically older) strata. As these Twin Creek beds are traced northeastward along strike, they become vertical, and then right-side-up and dip $80^{\circ}$ SE. (fig. 37). It is much as if vertical upward movement of the Arapien Shale has pushed up the overturned beds and bowed them back into their normal right-side-up sequence.

SkINNER PEAKs AREA

The extent of the Levan fold south of Little Salt Creek is speculative, being based chiefly on sparse outcrops of the Arapien Shale, and on the development of the westward-facing West Gunnison monocline. Near Skinner Peaks (D-3), about $6 \mathrm{~km}\left(3^{1 / 2} \mathrm{mi}\right)$ south of Little Salt Creek, the Arapien Shale crops out beneath westward-dipping $\left(20^{\circ}\right)$ volcanic rocks, part of the Goldens Ranch and Moroni Formations (Witkind and Marvin, 1989). I attribute this westward dip of the volcanic rocks to the upward movement of the underlying Arapien Shale. As these Arapien exposures are directly south of and collinear with those Arapien beds that crop out at Little Salt Creek, it seems reasonable to conclude that all are part of the core of the Levan diapiric fold.

Witkind and Marvin (1989), using potassium-argon techniques, have dated these volcanic rocks as having been formed during an interval that extended 


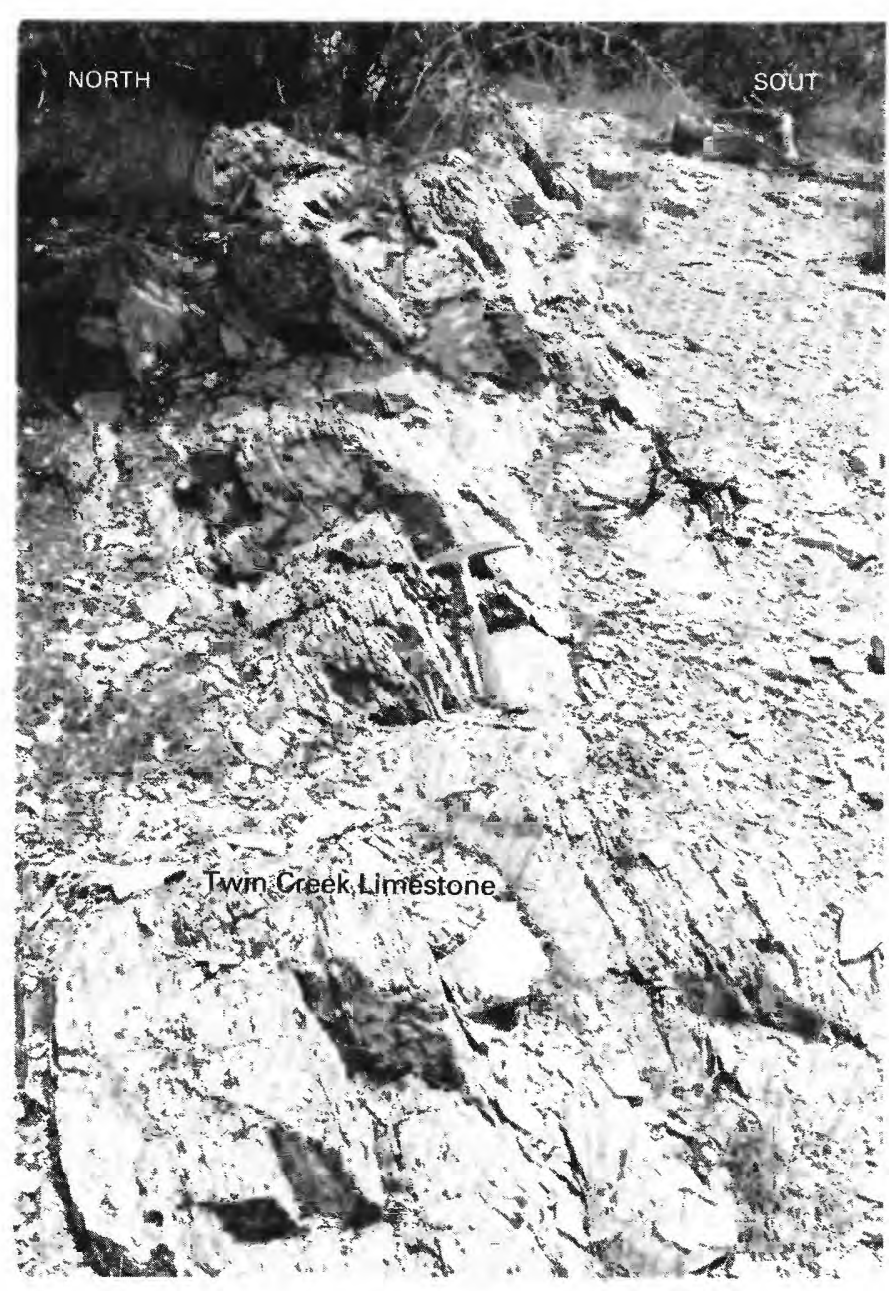

FIGURE 37.-View eastward along south wall of Red Canyon showing Twin Creek Limestone dipping steeply to the southeast. Mudstones, which I interpret to be part of the Arapien Shale, are exposed to the right of this view.

The rocks exposed along Red Canyon are part of the upper plate of the Charleston-Nebo thrust fault, which in central Utah appears as the lower limb of an overturned anticline. As a result, all strata are overturned and dip moderately to the northwest. In this specific locality, however, near the edge of the thrust plate, the beds of the Twin Creek are right-side-up and dip steeply to the southeast, exactly opposite to the dips of all other units in the area.

I interpret these relations to mean that the adjacent Arapien mudstones, part of the Levan diapiric fold, have locally bowed up and flexed back the formerly overturned beds of the Twin Creek Limestone, which once dipped northwest, so they now appear right-side-up dipping to the southeast.

from the late Eocene to the middle Oligocene. If the volcanics were indeed tilted as a result of upward movement of the Arapien, as I propose, then that movement must have occurred at some time after the middle Oligocene, long after the compressive events of the Sevier orogeny ended at the close of the Paleocene.
Mattox and Weiss (1987, p. 60), studying the southwest flank of the Gunnison Plateau, directly south of Skinner Peaks, have stated that salt diapirism has not "played a major role in the structural development of the study area." To support their contention they noted that Indianola beds east of and adjacent to the Chriss-Mellor graben dip gently eastward (Mattox, 1987) rather than being vertical or overturned as one might expect next to a diapiric upwarp. Seemingly, Mattox and Weiss have failed to grasp Witkind and Page's (1984) suggested explanation of the relations between salt diapirs and the monoclines in the Sanpete-Sevier Valley area. Witkind and Page proposed that partial removal of salt from a causative salt diapir resulted in subsidence of the overlying sedimentary beds to form a monocline. The causative diapir, thus, is at the toe - the distal end-of the downwarp. The large north-trending Chriss-Mellor graben of Mattox and Weiss (1987), which breaks the flank of the West Gunnison monocline, is at least $3 \mathrm{~km}(2 \mathrm{mi})$ east of the crest of the Levan diapir. One would not expect vertical or overturned beds this distant from the diapir.

Mattox and Weiss (1987, p. 58) described a distinctive thinning and pinch-out of the North Horn Formation along the southwest flank of the Gunnison Plateau and attributed it to the gradual uplift of a topographic and structural high west of one of the major faults - the Escarpment fault-in their area (1987, p. 60). I propose an alternative interpretation, that this thinning of the North Horn Formation is much like the depositional thinning that marks the various diapiric folds throughout the area (p. 107). If so, it strongly suggests that salt diapirism has played a significant role in this sector of the Gunnison Plateau.

The westward-facing position of the West Gunnison monocline implies that the crest of the Levan diapiric fold is concealed beneath those surficial deposits that fringe the west flank of the Gunnison Plateau.

In many respects, the north-trending ChrissMellor graben is similar to the many north- and northeast-trending grabens that break the west flank and crest of the Wasatch Plateau. These grabens appear to be salt derived; seismic reflection profiles across the Wasatch Plateau suggest strongly that the faults that bound the grabens do not extend below Jurassic strata, in essence, below Arapien and below Carmel beds. The implication is strong that dissolution of bedded salt resulted in the development of those grabens. 


\section{POLE CREEK DIAPIRIC FOLD}

GEOLOGIC SETTING;

The Pole Creek diapiric fold (fig. 16, 12) extends northeastward from near the north end of the Gunnison Plateau (D-3), where the Levan fold trifurcates, to its disappearance beneath young volcanic rocks, some $11 \mathrm{~km}(7 \mathrm{mi})$ away, near the head of the Middle Fork Pole Creek (B-4) (fig. 38).

\section{KOA CAMPGROLND AREA}

About $8 \mathrm{~km}(5 \mathrm{mi})$ east of Nephi (B-3), where the scenic Nebo Loop Road joins State Highway 132 (near a KOA Campground (C-3)), amorphous, earthy, reddish-brown Arapien mudstones crop out between extensive exposures of volcaniclastic rocks (southwest corner of area shown in fig. 38). Where these volcaniclastics, part of the Moroni Formation of late Eocene to middle Oligocene age, overlie the northwest flank of the Arapien exposures, they dip about $25^{\circ} \mathrm{NW}$; where they overlie the southeast flank they dip southeastward about $30^{\circ}$. About $1.6 \mathrm{~km}(1 \mathrm{mi})$ northeast of the aforementioned road junction, Indianola conglomerates, unconformably underlying the volcaniclastic rocks and overlying the Arapien Shale, crop out along the west valley wall of Pole Creek. The conglomerates dip about $60^{\circ} \mathrm{NW}$. Directly across the valley, which is floored with alluvium but is most likely underlain by the Arapien Shale, comparable Indianola beds, also unconformably interleaved between the volcaniclastics and the Arapien Shale, are vertical or dip steeply to the southeast. Thus, both Moroni and Indianola units unconformably overlie and dip away from the Arapien exposures.

In places, these Moroni volcaniclastics are overlain unconformably by semiconsolidated sands, gravels, and boulders of the Salt Creek Fanglomerate (Eardley, 1933a), which also dip away from the Arapien exposures but not as steeply as the underlying volcaniclastics.

I interpret the Arapien beds to be the crest of the diapiric core of the northeast-trending Pole Creek fold, and the upturned beds that flank the Arapien exposures to be segments of the upturned flanks of the fold. From the road junction, the crest of the fold trends about $\mathrm{N}$. $45^{\circ} \mathrm{E}$. and can be traced into the Middle Fork Pole Creek (fig. 39A).

The fact that units of the Indianola Group, the Moroni Formation, and the Salt Creek Fanglomerate conform in direction of dip but differ greatly in amounts of dip implies several episodes of deformation. Presumably, one episode occurred after the Indianola beds (of Late Cretaceous age) were consolidated; a second deformational episode must have occurred after the volcaniclastic sediments (of mid-Tertiary age) were emplaced and partly consolidated, and a third occurred during early(?) Quaternary time, at some time after the Salt Creek Fanglomerate was formed.

As shown in cross section $A-A^{\prime}$ (center) of figure 38, I propose that the units commonly present between the Arapien and the Indianola-the Twist Gulch and Cedar Mountain Formations-pinch out against the flanks of the diapiric core. Farther to the northeast, in the Middle Fork Pole Creek, both the Twist Gulch and the Cedar Mountain Formations are exposed between the Arapien and the Indianola but as extremely thin remnants.

\section{Middle Fork Poie Creek}

The core of the Pole Creek fold and the sedimentary rocks that form its southeast flank crop out in the Middle Fork Pole Creek (fig. 39A). Best exposures are in $\mathrm{C}$ sec. 13, T. 12 S., R. 2 E. The Arapien Shale, part of the core of the fold, forms the northwest bank of Middle Fork; vertical units of the Twist Gulch are exposed in the narrow stream bottom (fig. $39 B, C$ ), and Cedar Mountain beds form the eastern stream bank. The Twist Gulch and Cedar Mountain Formations are extremely thin; determining their exact thicknesses is difficult, for much of the area is mantled with colluvium and shrubs. I estimate the Twist Gulch to be about $60 \mathrm{~m}(200 \mathrm{ft})$ thick, and the Cedar Mountain to be about $250 \mathrm{~m}$ (800 ft) thick. Elsewhere in the Sanpete-Sevier Valley area, the Twist Gulch is about $915 \mathrm{~m}(3,000 \mathrm{ft})$, and the Cedar Mountain about $550 \mathrm{~m}(1,800 \mathrm{ft})$ thick.

These exposures in the Middle Fork Pole Creek are flanked on the southeast by beds of the Indianola Group that are vertical, or dip steeply southeastward. To the northwest these Middle Fork exposures are flanked by volcanic beds of the Moroni Formation

Figure 38 (following pages).-Geology across Pole Creek-Hop Creek area, Cedar Hills. Base modified from U.S. Geological Survey 1:100,000 Nephi (1981). Contour interval $250 \mathrm{~m}$. The broad geologic pattern of the Cedar Hills has been determined by the Pole Creek diapiric fold, whose crest on this map is delineated by a dashed line. The fold trends approximately N. $45^{\circ} \mathrm{E}$. through the area, and probably joins the Dry Hollow diapiric fold (fig. 16, 10). Arapien mudstones are exposed beneath volcaniclastic sediments at the stream junction shown in the lower left corner of the map, and in Middle Fork Pole Creek. Strata west of the Arapien exposures dip westward, strata east of those exposures dip eastward. Crest of the fold is well exposed in Middle Fork Pole Creek. (See fig. 39.) 

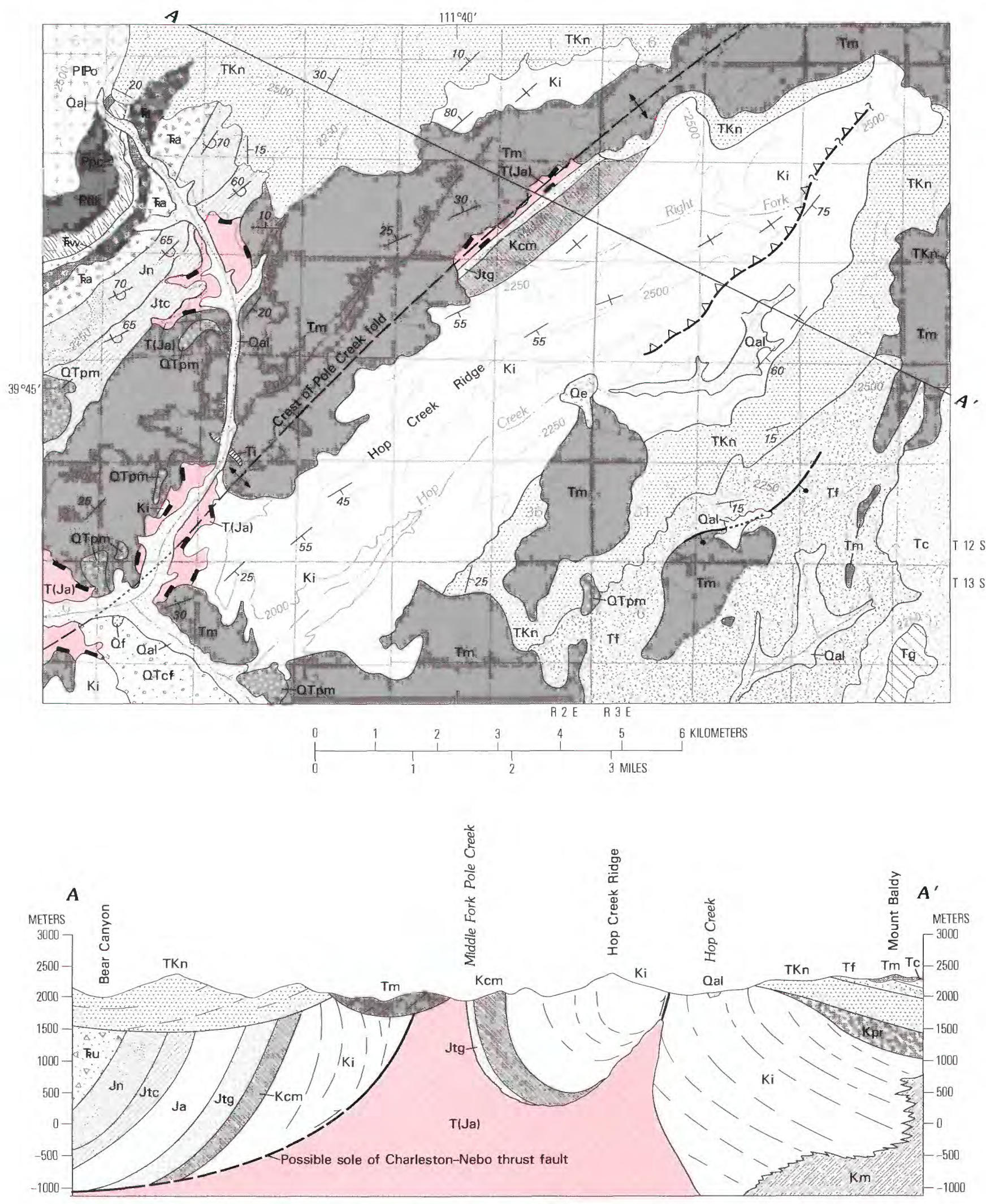
EXPLANATION
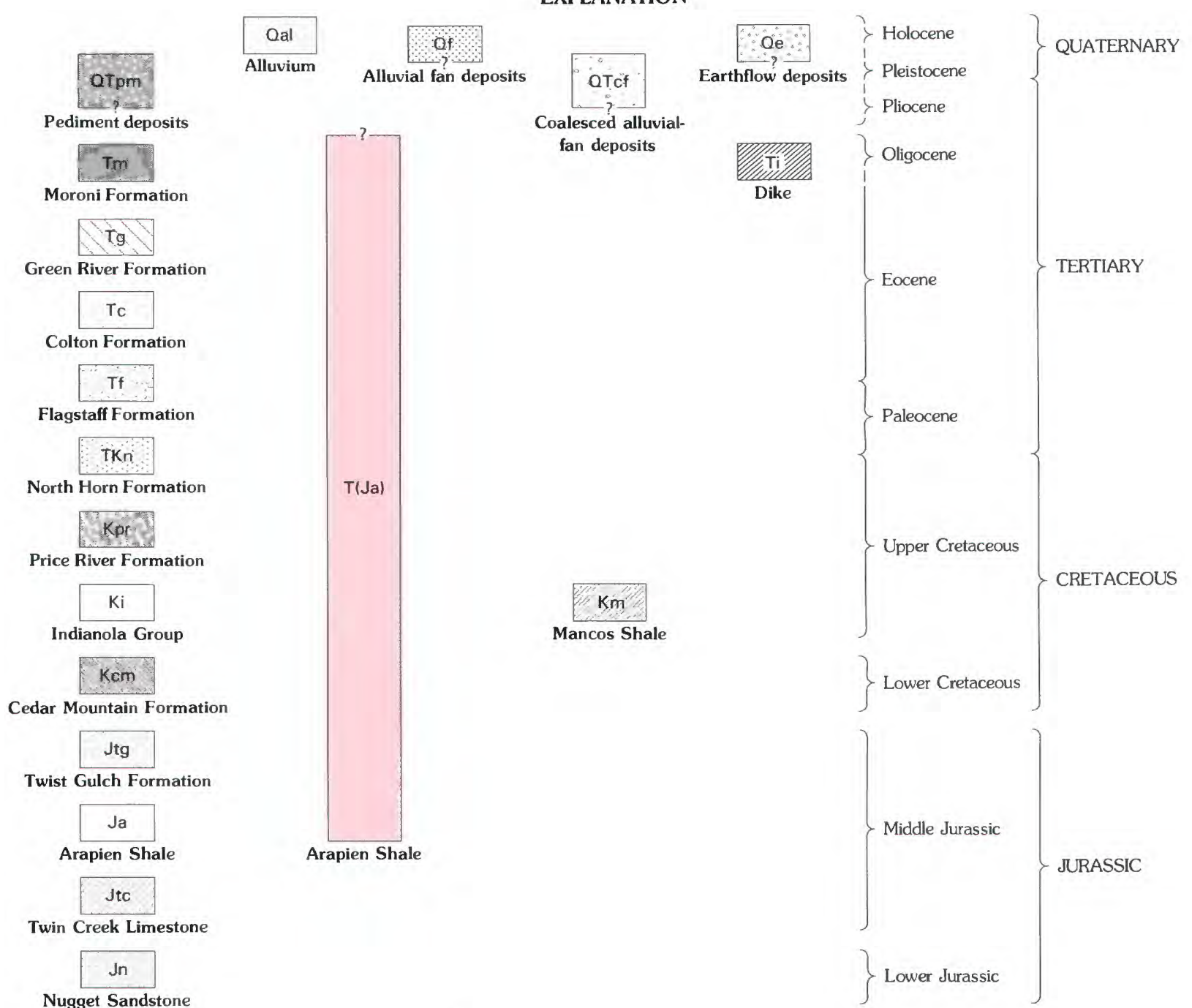

Twin Creek Limestone

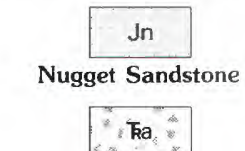

Ankareh Formation

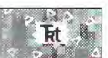

Thaynes Limestone

$$
\text { Kw }
$$

Woodside Formation

$$
\text { Aptive }
$$

Park City Formation

\section{Pdk}

Diamond Creek Sandstone and Kirkman Limestone

$$
\text { P PPO }
$$

Oquirrh Group
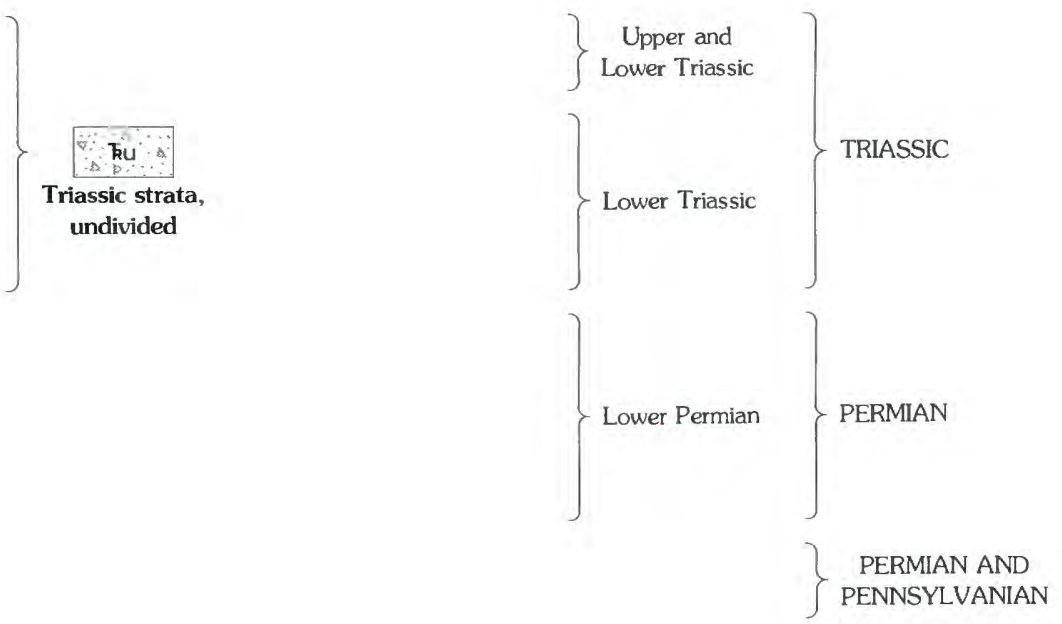

$$
\text { Contact-Approximately located or inferred }
$$

- - Intrusive contact-Approximately located or inferred; oblongs on intrusive unit Fault-Dotted where concealed; bar and ball on downthrown block

$\triangle \wedge \Delta$ High-angle reverse fault-Dashed where approximately located; queried where uncertain; sawteeth on upthrown plate; barb shows upthrown plate in cross section 


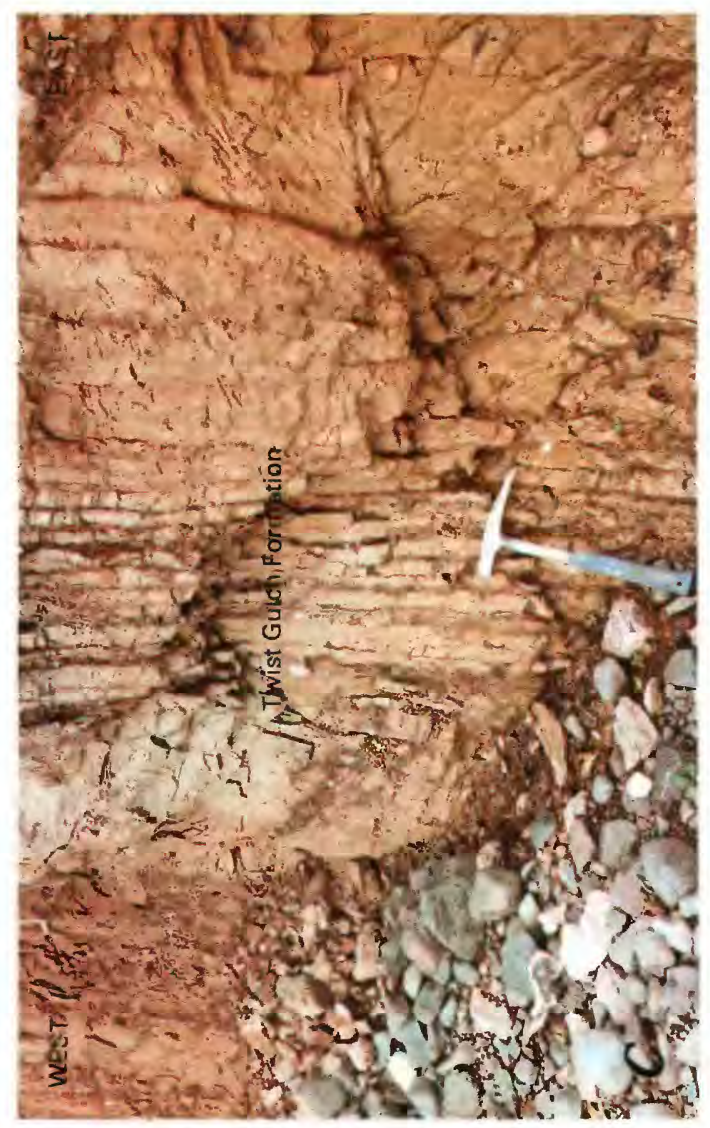

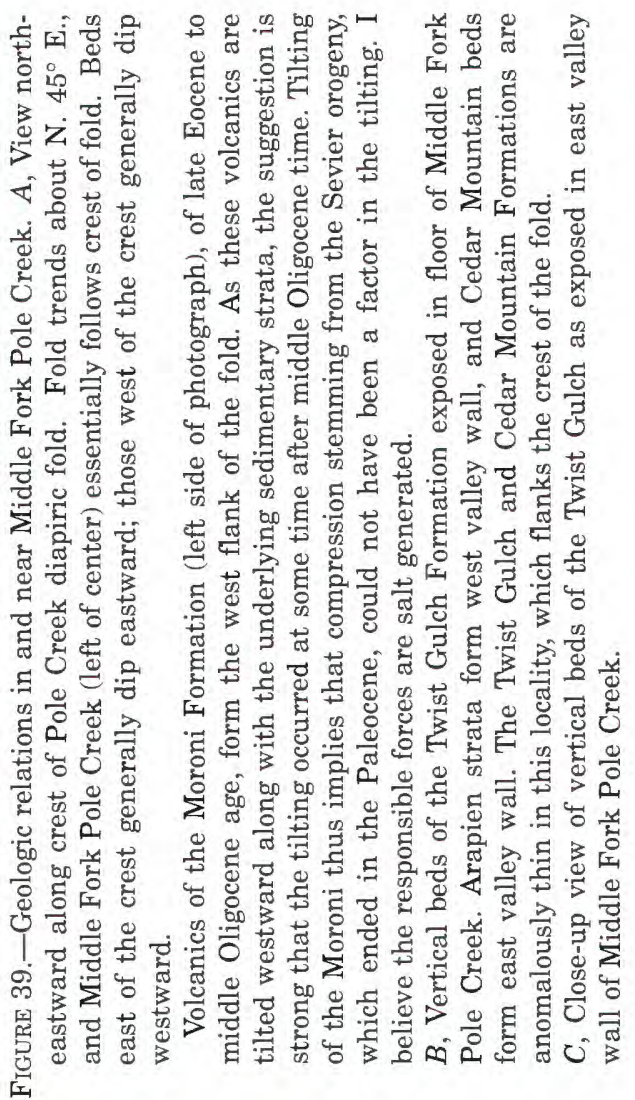
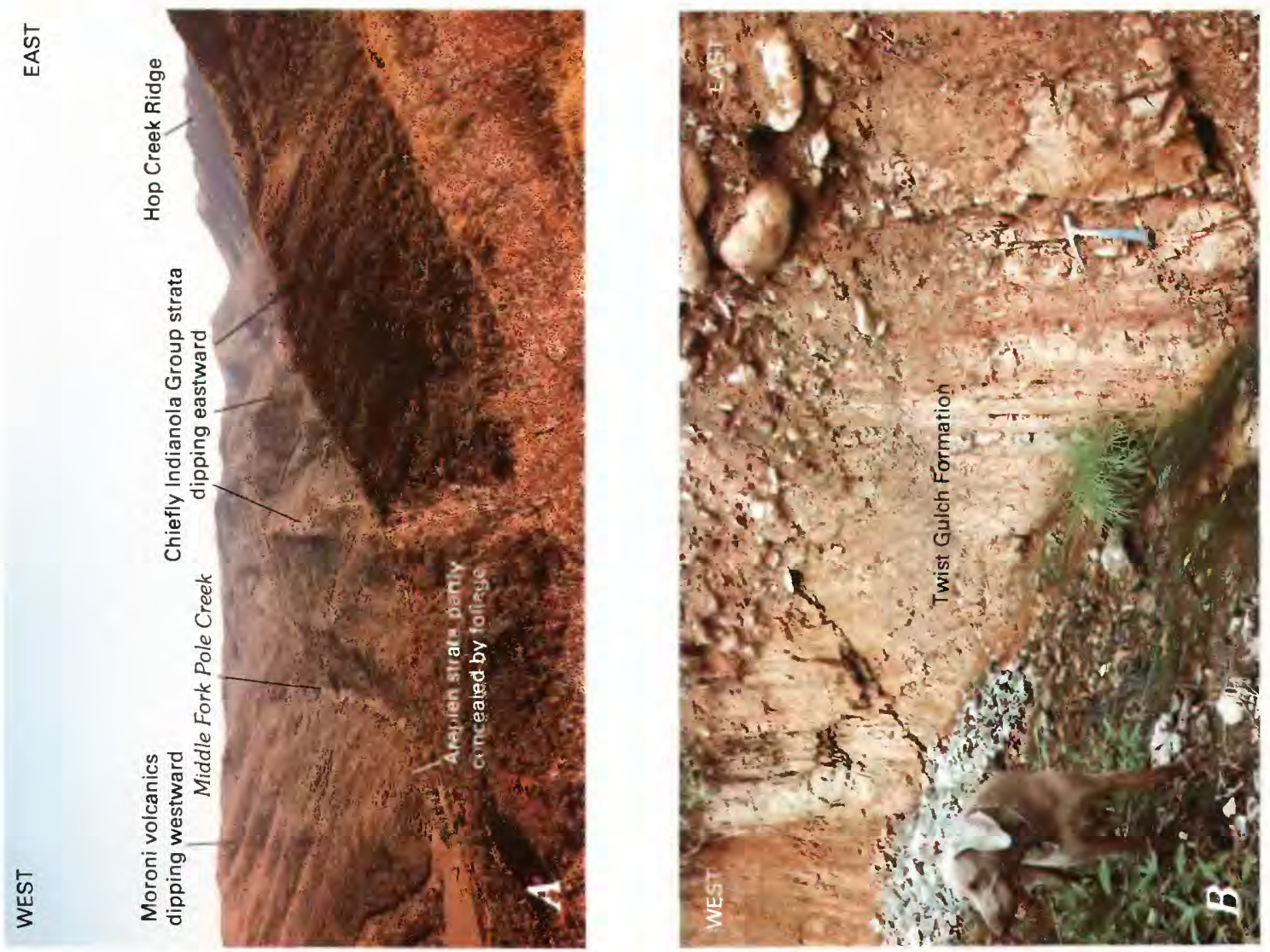
that dip moderately northwestward. In places, this volcanic cover has been breached to expose Indianola beds that are vertical or dip steeply northwestward. Near the head of the Middle Fork Pole Creek, these vertical Indianola beds are overlain by North Horn strata that dip away from the crest of the fold-beds east of the crest dip about $45^{\circ} \mathrm{SE}$., beds west of the crest $\operatorname{dip} 10^{\circ}$ to $20^{\circ} \mathrm{NW}$.

\section{DISCUSSION}

These exposures, in Pole Creek and in the Middle Fork Pole Creek, imply that the Arapien mudstones were slowly rising, presumably as an ancestral northeast-trending ridge, even as Twist Gulch sediments were being deposited. This dynamic paleo-high impeded the deposition of Twist Gulch and successive younger sediments. The fact that Twist Gulch sediments thin is most significant, for the Twist Gulch is the next younger unit deposited after the Arapien. This must mean that the salt began its slow upward movement shortly after it was deposited.

This slow upwelling of the salt apparently was disrupted at least twice by more rapid upward surges of the salt: once during the Late Cretaceous when the Indianola beds were bowed up, and again when the volcanic rocks were bowed up. As the volcanic and volcaniclastic rocks are part of the Moroni Formation, tentatively dated as having been formed during the late Eocene to middle Oligocene (Witkind and Marvin, 1989), this second deformational episode must have occurred at some time after the middle Oligocene. These age relations reemphasize the fact, noted from structural relations near Skinner Peaks, that the forces responsible for this second deformational episode, whatever their origin, could not have stemmed from the Sevier orogeny, for that orogeny came to an end at the close of Paleocene time (Armstrong, 1968, p. 449).

The deformational sequences in the Middle Fork Pole Creek, thus, are similar to those in the KOA Campground area, and to those in the Skinner Peaks area along the west flank of the Levan diapiric fold.

The Pole Creek fold has determined the structural pattern of the Cedar Hills. West of Pole Creek, all strata, volcanic as well as sedimentary, are vertical or dip northwestward toward the Charleston-Nebo thrust plate. East of Pole Creek, most strata are either vertical or dip steeply southeastward; in a few places these beds are overturned to the southeast and so dip steeply to the northwest. These steeply dipping to vertical strata, all part of the Indianola Group, are well exposed along Hop Creek Ridge and in Hop Creek (fig. 40).
The Pole Creek fold not only has determined the pattern of the Cedar Hills, but it seemingly has also modified the north end of the Gunnison Plateau and the exposed east edge of the Charleston-Nebo thrust plate. So, the north end of the Gunnison Plateau is tilted southeastward, presumably bowed up by the rising diapiric core. I believe the northwestward tilt of the Charleston-Nebo thrust plate, near Nephi (B-3), reflects the northwest flank of the Pole Creek fold and stems, in part, from the same upward movement of the core.

Apparently, the Pole Creek fold continues northeastward concealed beneath the volcanic mantle, and eventually reappears east of Thistle in Dry Hollow to form the Dry Hollow diapiric fold (fig. 16, 10).

\section{FOOTES CANYON DLAPIRIC(?) FOLD}

The trifurcation of the Levan diapiric fold, at the north end of the Gunnison Plateau, resulted in three major diapiric folds. I have discussed both the western (Levan) and eastern (Pole Creek) folds, and in this section I describe the sparse surface evidence that hints at the existence of the middle, Footes Canyon (B-3) fold (fig. 16, 13).

In general, I believe that the Footes Canyon fold trends about N. $15^{\circ} \mathrm{E}$., extending from the north end of the Gunnison Plateau to some indefinite point beneath the Charleston-Nebo thrust plate. Footes Canyon, a minor tributary that breaks the north wall of Salt Creek, probably follows the crest of the fold, for Arapien strata are exposed all along the canyon's length, and the consolidated strata that overlie these Arapien mudstones appear to be tilted away from the crest. Thus, Indianola(?) conglomerates that form part of the northwest valley wall of Footes Canyon are tilted northwestward. These conglomerates seemingly define the northwest flank of the fold. The southeast flank of the fold is indistinct, chiefly because of thick forest cover and the debris shed by the disintegrating volcanic units that overlie the Arapien exposures. On the basis of a few poor exposures, I believe that these volcanic units of the Moroni Formation dip southeastward. At the north end of Footes Canyon the Arapien mudstones pass below the Charleston-Nebo thrust plate.

Although only sparse surface data are available to establish the existence of the Footes Canyon fold, considerable evidence along the eroded flank of the Charleston-Nebo thrust plate implies that the plate, and a mantle of sedimentary rocks that once overlay the plate, were bowed up at some time after the plate was emplaced (Witkind, 1987). As the trend of the Footes Canyon fold, projected northeastward, is 


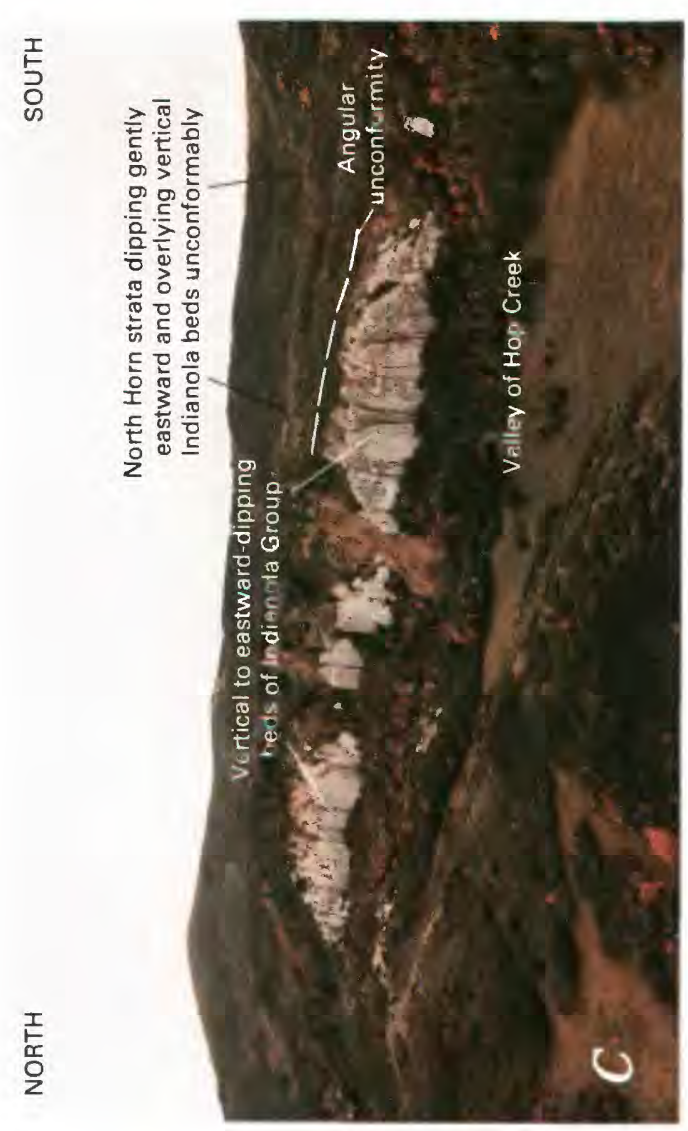

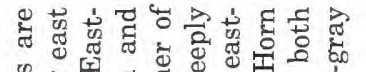

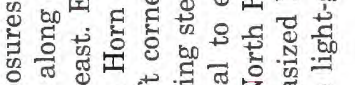

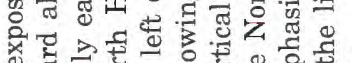

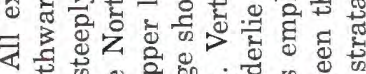

i

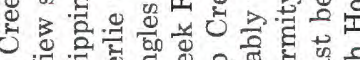

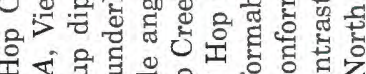

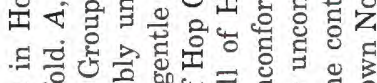

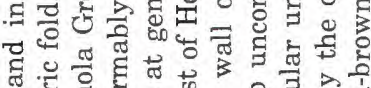

ส.

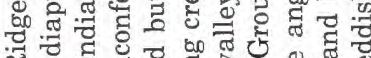

我

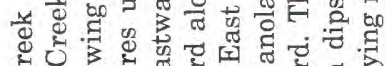

0

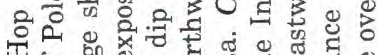

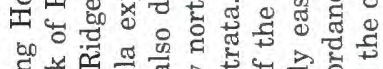

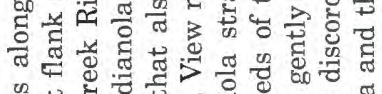

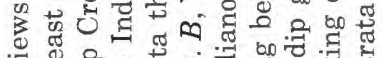

5 \%

1.

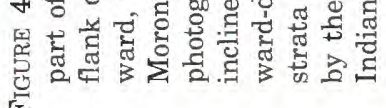
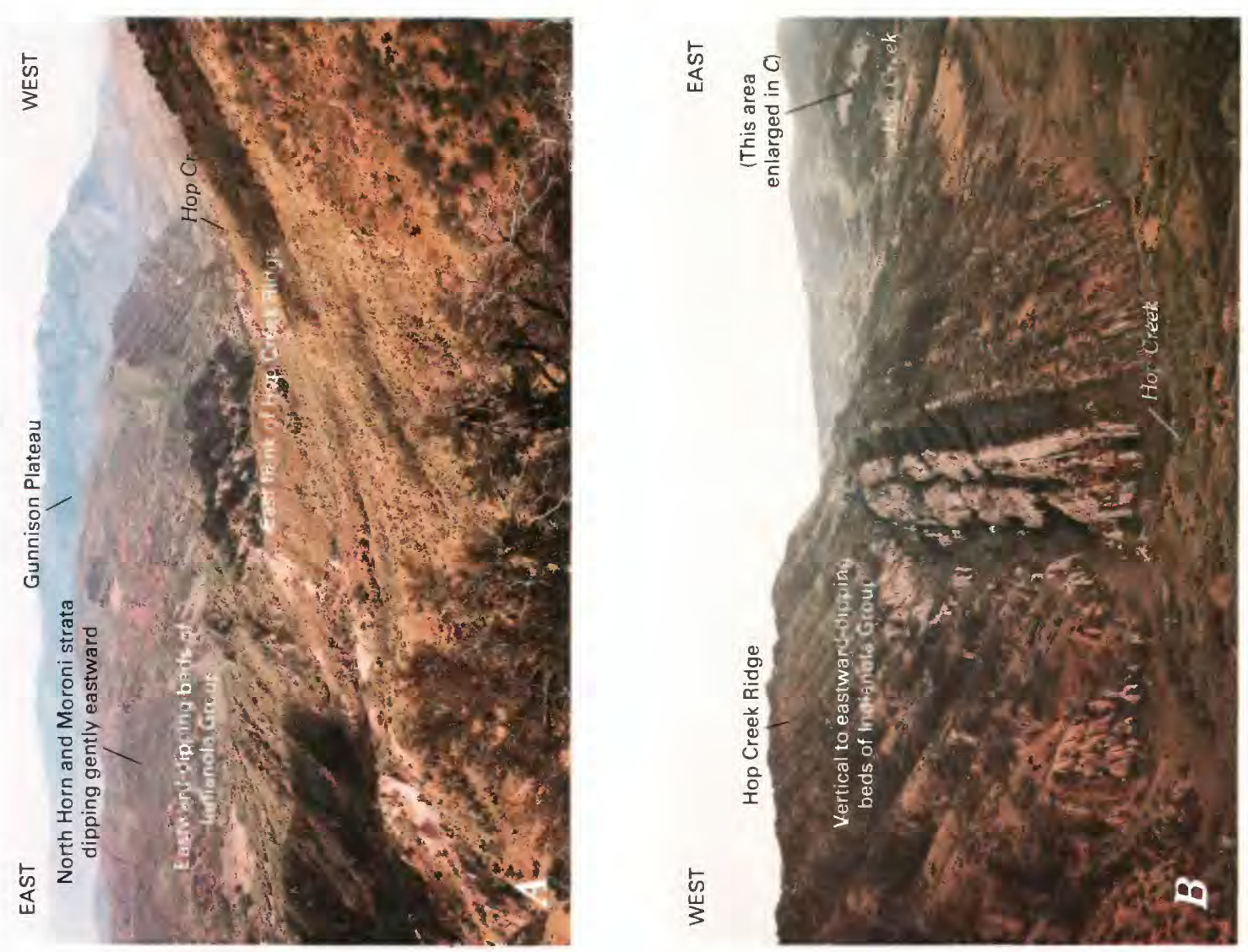
adjacent and parallel to the eroded margin of the thrust plate, I attribute the bowing up of the plate to movement along the Footes Canyon fold. The detailed evidence, involving the deformation of the Charleston-Nebo plate, is summarized elsewhere in this report (p. 104-107).

\section{DRY HOLLOW DIAPIRIC FOLD}

Vertical to overturned beds of the Indianola Group, striking about N. $40^{\circ} \mathrm{E}$., crop out southeast of Thistle $(\mathrm{A}-5)$ in a deep canyon known as Dry Hollow (A-5) (fig. 41). The canyon, tributary to northwest-flowing Lake Fork (A-5), trends northeastward, its course seemingly determined by the strike of the steeply dipping Indianola beds. These vertical to near-vertical strata are overlain with striking angular unconformity by gently dipping reddish-brown conglomerate, sandstone, and mudstone beds of the North Horn Formation (fig. 42). North Horn beds that overlie the northwest flank of the fold dip northwestward at about $25^{\circ}$; those that overlie the southeast flank dip southeastward at about $10^{\circ}$.

These exposures represent the crest and flanks of the northeast-trending Dry Hollow diapiric fold (fig. 16,10 ), of which only part crops out in Dry Hollow. The fold extends to the northeast across both Lake Fork and Soldier Creek (A-5) and passes below inclined North Horn beds exposed along the north valley wall of Soldier Creek. On the basis of these limited exposures the fold trends about N. $40^{\circ} \mathrm{E}$. for some $6 \mathrm{~km}$ (4 mi), reaching from the head of Dry Hollow to the north wall of Soldier Creek Canyon. The extent of the fold to the southwest is uncertain; it may connect with the Pole Creek fold (fig. 16, 12).

North Horn and Flagstaff strata near the upturned Indianola beds are unusually thin compared to their thicknesses elsewhere in the area.

As shown in figure 43, I interpret these exposures to represent deformation of part of the CharlestonNebo thrust plate by a rising mass of the Arapien Shale. The thrust plate- the lower limb of an anticline-overrode a mass of the Arapien Shale, probably during the Late Cretaceous (fig. 43, I). Subsequently, Arapien Shale, forced upward by slowly upwelling salt, bowed up the thrust plate to form a paleo-high that restricted deposition of sediments (fig. 43, II). Price River sediments, deposited against the flanks of this rising high, locally pinch out (fig. 43, III). Younger sediments, such as the North Horn and Flagstaff Formations, both pinch out against the flanks of the high and locally bury it. The Arapien probably continued to rise until well into the Tertiary, judging by the fact that volcanic units tentatively dated as late Eocene to middle Oligocene have been deformed along with the underlying sedimentary rocks. At some time after the upward movement of the rising Arapien ceased, erosion removed the volcanic cover as well as many of the underlying younger Tertiary sedimentary units. In time, erosion effectively breached the crest of the rising high to expose the vertical and overturned Indianola beds of the thrust plate (fig. 43, IV).

In several other areas where diapiric folds are exposed, erosion has been extensive enough to break through those sedimentary units that form the crest of the fold and expose the Arapien core. Seemingly, erosion has not been as extensive in the Dry Hollow area, and the upturned Indianola beds have not, as yet, been completely breached to expose the Arapien core (cross section $A-A^{\prime}$, fig. 41).

\section{THISTLE CREEK DIAPIRIC(?) FOLD}

The Thistle area (A-5), some $40 \mathrm{~km}(25 \mathrm{mi})$ southeast of Provo, is perhaps best known for the disastrous landslide of April 1983 that effectively blocked the major road and rail connections between Price, east of the Wasatch Plateau, and Provo, west of the plateau. Geologic aspects of the slide, its multiple impacts on the economic life of central Utah, and the potential geologic hazards near the slide have been described and discussed elsewhere (Duncan, Fleming, and Patton, 1986; Kaliser and Fleming, 1986; Witkind, 1986; Willis, 1987).

\section{GEOLOGIC SETTINC}

In the Thistle area, arched Cretaceous and Tertiary strata overlie the Charleston-Nebo thrust plate and suggest the presence of a diapiric fold (fig. 16, 11; cross section $A-A^{\prime}$, fig. 44 ).

Two major elements dominate the geologic framework of the Thistle area: the eroded east margin of the major Charleston-Nebo thrust plate, and a sequence of younger Cretaceous and Tertiary sedimentary and volcanic rocks that unconformably overlies and partly buries the thrust plate.

Charleston-Nebo Thrust Piate

The basic elements of the Charleston-Nebo thrust plate have been described on pages 8 to 9 . In the Thistle area, the easternmost exposed rocks of the thrust plate form a high ridge that trends slightly east of north. It is unclear whether this ridge is at the distal margin of the thrust plate (fig. $4 A$ ) or 
whether the distal margin is farther east buried beneath younger strata (fig. $4 B$ ). If the latter, the plate margin in the Thistle area is an erosional escarpment cut on the thrust plate (fig. $4 B$ ). Because of uncertainty as to which of these two alternatives is correct, I refer to this eastern part of the thrust plate as an "erosional escarpment," and delineate it on figure 44 by hachures.

Spanish Fork River and its tributaries, westflowing Soldier Creek (A-5) and north-flowing Thistle Creek (A-4), have cut a deep canyon, shaped somewhat like a $T$ on its side, through the ridge. That part of the ridge north of the confluence of Soldier and Thistle Creeks is unnamed; in the past, crews involved in the construction of Thistle dam and the new segment of U.S. Highway 6 and 89 incorrectly called it "Billies Mountain," but in fact, Billies Mountain is some $3 \mathrm{~km}(2 \mathrm{mi})$ to the northeast. Continued incorrect usage, however, has transferred the name Billies Mountain to the north part of the ridge, and in this report I follow that custom but alert the reader to this misusage by placing the name in quotes, thus, "Billies Mountain."

In the Thistle area, the rocks in the thrust plate range in age from Pennsylvanian to Jurassic (table 2). Most of them dip eastward at moderate to high angles; in the ridge, along the eastern part of the thrust plate, Navajo (Jn on the map) and Twin Creek (Jtc) strata dip eastward at about $60^{\circ}$. Farther west, toward the main mass of the thrust plate, successively older strata dip east but at about $40^{\circ}$.

\section{Sedimentary Sequence of Younger Rocks}

The deeply eroded plate is partly buried by younger sedimentary rocks of Late Cretaceous to Eocene age. Locally, these rocks are mantled by pyroclastic volcanic rocks of the Moroni Formation (late Eocene to middle Oligocene). East of the erosional escarpment, the younger sedimentary and volcanic rocks dip eastward at low to moderate angles $\left(10^{\circ}-\right.$ $30^{\circ}$ ). By contrast, the same strata west of the escarpment dip westward at moderate angles (fig. 45A). Wherever exposed, these younger sedimentary and volcanic rocks unconformably overlie the eastwarddipping rocks of the thrust plate.

These younger sedimentary rocks thin markedly toward the erosional escarpment. This is perhaps best shown in a diagram prepared by Young (1976, fig. 5), which shows a westward thinning of all strata, extending from the North Horn to the Green River Formation.

\section{STRATA NORTH OF SPANISH FORK CANYON ("BILLIES MOUNTAIN" AREA)}

Most of these younger Cretaceous and Tertiary strata are well exposed where they mantle the thrust
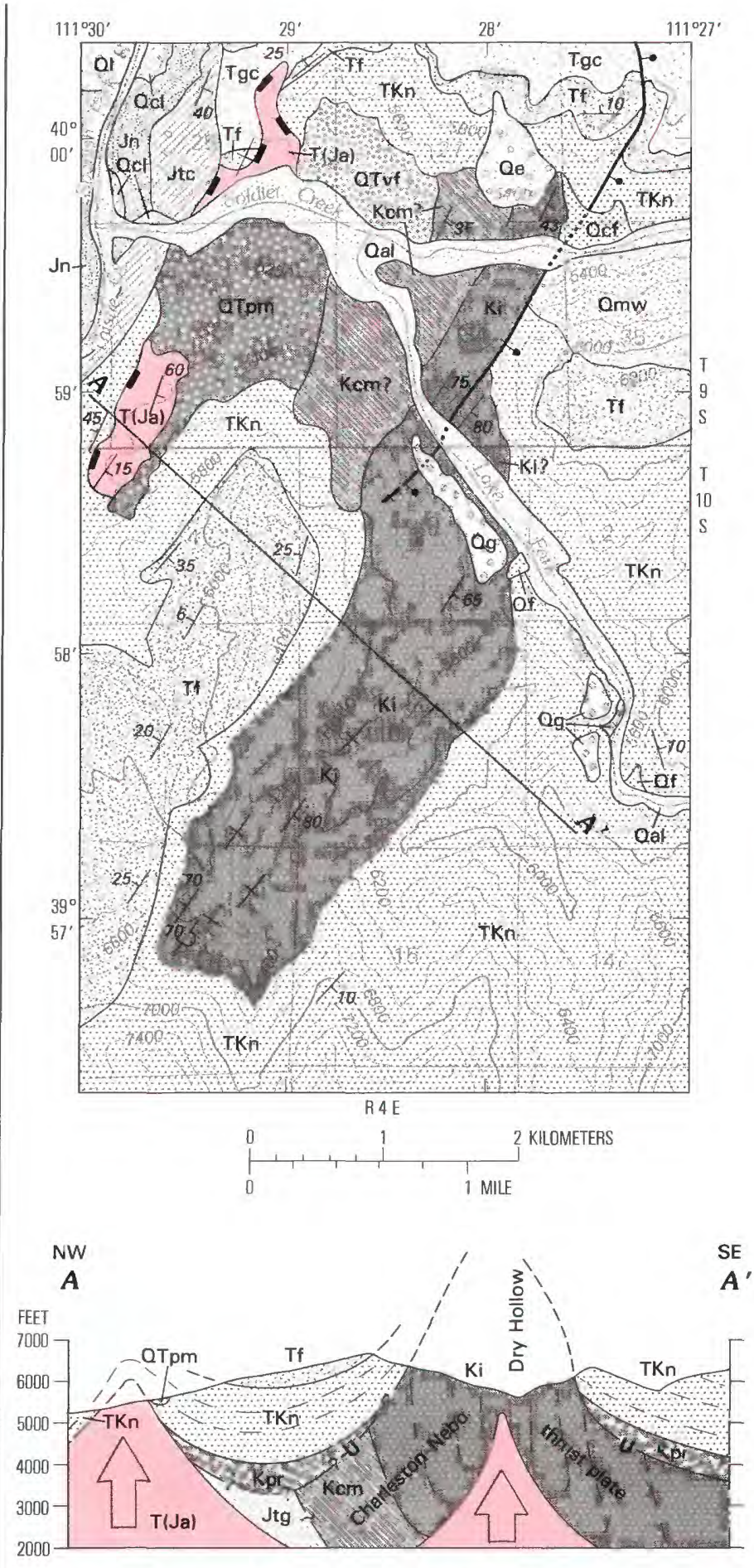

Figure 41 (above and facing page)-Geology of Dry Hollow area. Base modified from U.S. Geological Survey 1:24,000 Thistle (1967). Contour interval $200 \mathrm{ft}$. In Dry Hollow, which follows the crest of the Dry Hollow diapiric fold, vertical beds of the Indianola Group, possibly part of the Charleston-Nebo thrust plate, pass below and unconformably underlie beds of the North Horn Formation. North Horn strata east of the crest of the fold dip gently eastward; similar strata west of the fold's crest dip gently westward. Near the west edge of the map area these westward-dipping North Horn strata abruptly reverse dip and dip eastward, reflecting a small intrusive mass of Arapien Shale. 

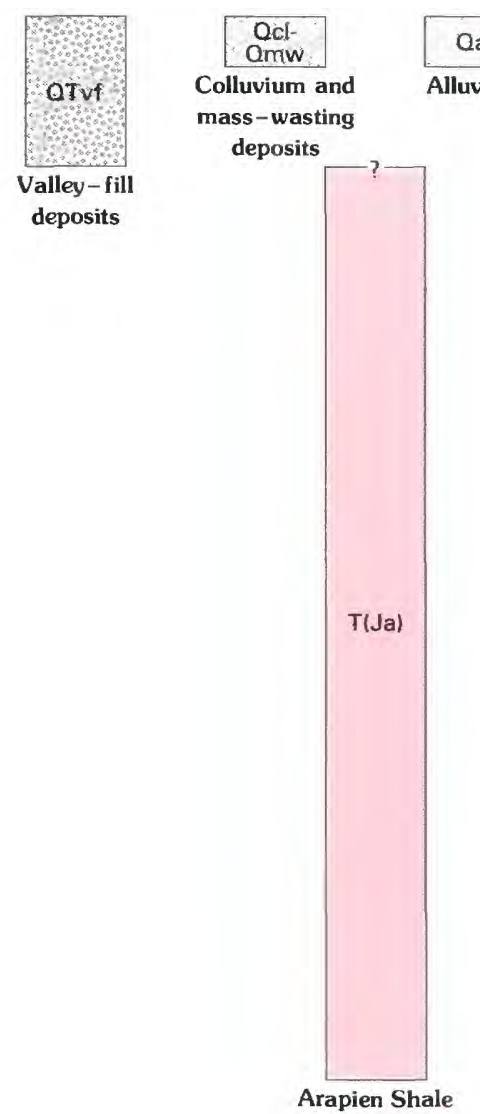

\section{EXPLANATION}

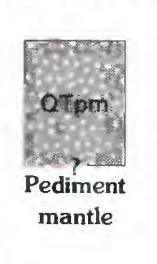

Green River Formation and Colton Formation

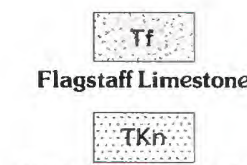

North Horn Formation

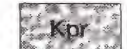

Price River Formation

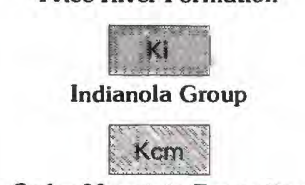

Cedar Mountain Formation

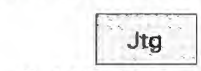

Twist Gulch Formation

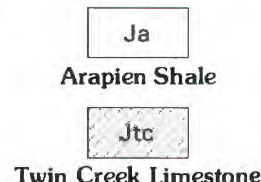

Twin Creek Limestone
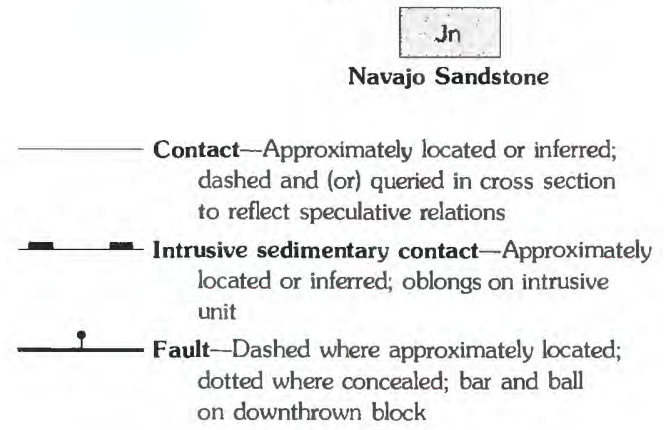
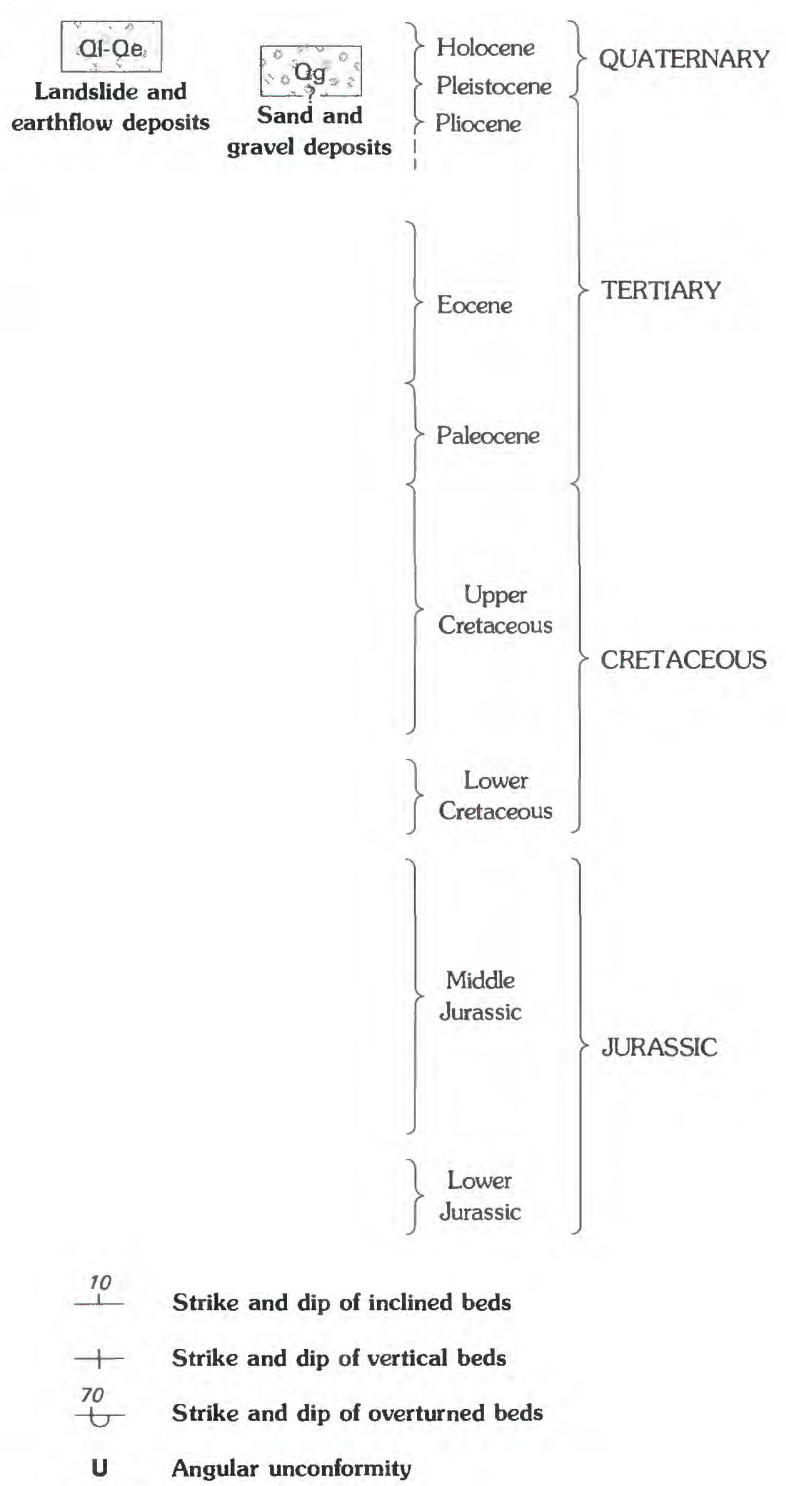

plate south and west of Spanish Fork Canyon, but they have largely been eroded from much of the thrust plate north and east of the canyon. Some units do crop out north of the canyon as a series of eastward-dipping strata that lap onto the east margin of the plate.

This general pattern of eastward-dipping strata is interrupted, however, north of Soldier Creek directly east of "Billies Mountain." There, the Flagstaff Limestone ( $\mathrm{Tf}$ ) abuts the east flank of "Billies Mountain" at an eastward dip of about $20^{\circ}$ (fig. 44). About 150 $\mathrm{m}(500 \mathrm{ft})$ east of the ridge, the Flagstaff gradually flattens, and then reverses and dips moderately to steeply westward; locally these strata are almost vertical (fig. $45 B$ ). Although the Flagstaff Limestone is underlain by the North Horn Formation throughout most of central Utah (table 1), in this specific locality the near-vertical beds of the Flagstaff are underlain by the Arapien Shale. These Arapien strata, chiefly calcareous mudstones, are severely contorted and broken.

The deformed Arapien strata, and the relations between the Flagstaff and the Arapien, suggest that the Arapien, driven by its contained salt, has raised and tilted back the Flagstaff Limestone.

Elsewhere in this general area, other exposures indicate the intrusive nature of the Arapien. Thus, during excavation, the earth-moving equipment time and again exposed wedgelike masses of Arapien Shale that intrude and deform the steeply tilted beds 


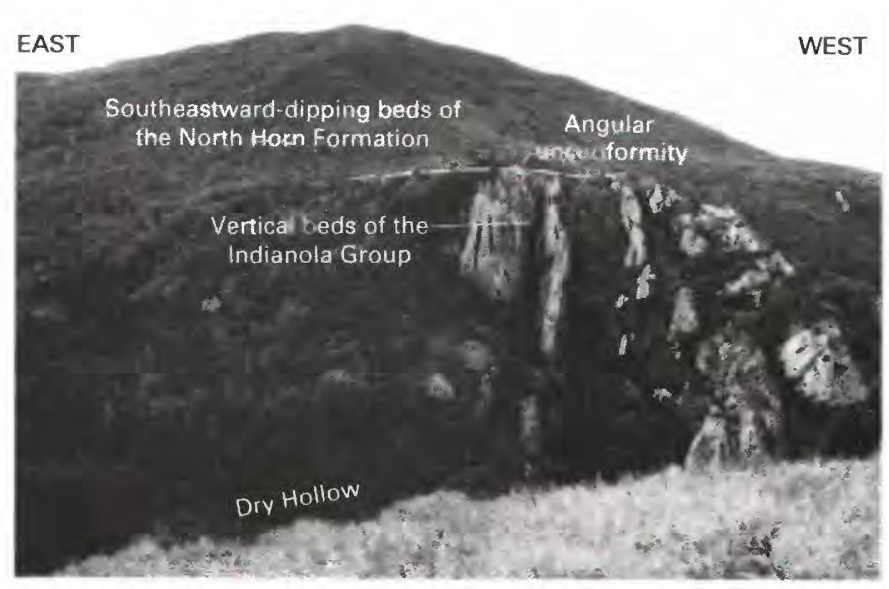

Figure 42.-View southward near head of Dry Hollow showing angular unconformity. Vertical light-gray beds of the Indianola Group unconformably underlie reddish-brown North Horn strata that dip gently southeast.

of Twin Creek in the thrust plate (fig. 11A). At the east edge of "Billies Mountain" a dike-like mass of the Arapien separates the Twin Creek strata of the thrust plate from the tilted units of the Colton Formation that lap onto the erosional escarpment of the plate (fig. 11B). Sills of the Arapien, containing both nodules and masses of gypsum and clasts of the Twin Creek Limestone, intrude the Twin Creek Limestone (fig. 46).

East of "Billies Mountain," where the steeply tilted beds of Flagstaff Limestone are underlain by the intensely contorted Arapien strata (fig. 45B), the deformed Arapien beds pass eastward into noncontorted but nearly vertical Arapien strata. These Arapien beds are right-side-up and lack the crumpled and contorted aspect of the profoundly disturbed Arapien beds. As these steeply dipping Arapien strata are traced eastward, they seem to conformably underlie the Twist Gulch Formation, which in turn underlies the Cedar Mountain Formation. The unbroken progression of beds, in normal stratigraphic sequence east from the disturbed mass of Arapien, implies that the thrust plate extends eastward beyond the erosional escarpment. Two alternatives are possible: (1) the mass of disturbed Arapien punched up through Arapien beds that were part of the plate, or (2) the disturbed Arapien beds, integral elements of the thrust plate, became mobile and then deformed the overlying strata. Of the two interpretations, I prefer the former: I believe that an underlying overridden mass of Arapien Shale punched up and deformed the thrust plate (cross section $A-A^{\prime}$, fig. 44). Intrusive fingers of the Arapien invaded both the plate and the adjacent younger strata. In this interpretation, the contorted Arapien strata and the less deformed Arapien beds of the thrust plate are fortuitously juxtaposed.

Other examples of Arapien deformation are exposed elsewhere in the general area. So, for example, a small mass of Arapien Shale (labeled T(Ja) in fig. 44) crops out along the east valley wall of Thistle Creek about $0.8 \mathrm{~km}(1 / 2 \mathrm{mi})$ south of the confluence of Soldier and Thistle Creeks. West of that outcrop, North Horn (TKn) beds dipping eastward, off the erosional escarpment cut on the thrust plate, flatten and then reverse attitude to assume a steep westward dip directly adjacent to the west flank of the Arapien exposure. East of the Arapien mass, the North Horn beds dip eastward. These opposing dips in North Horn strata that flank the Arapien lead to the inference that consolidated North Horn strata have been arched by an intrusive mass of the Arapien Shale (cross section $A-A^{\prime}$, fig. 44 ).

STRATA SOUTH AND WEST OF SPANISH FORK CANYON

Younger sedimentary and volcanic rocks mantle parts of the thrust plate exposed south and west of Spanish Fork Canyon. Indeed, detritus from these younger rocks, chiefly the North Horn Formation,

FiguRE 43 (facing page).-Diagrammatic sketches suggesting how the Dry Hollow diapiric fold developed. All views are oriented in same compass directions.

I. During the Late Cretaceous, the Charleston-Nebo thrust plate-the lower limb of an overturned anticline-overrode units of the Arapien Shale $(\mathrm{K}(\mathrm{Ja}))$. In this schematic cross section only some of the units that make up the thrust plate are shown.

II. After the thrust plate ground to a halt, the overridden Arapien Shale began to well upward slowly, gradually intruding the plate and bowing it upward. In this sketch erosion has beveled the bowed-up thrust plate to produce a surface of low relief.

III. Price River sediments (Kpr) began to be deposited on this surface of low relief. Incessant slow upwelling of the Arapien $(\mathrm{T}(\mathrm{Ja})$ ) continued to bow up the plate, thus restricting deposition of Price River sediments, which locally pinched out against the flanks of the rising high. The Price River units unconformably overlay units of the thrust plate. In time, North Horn sediments (TKn) were deposited on the Price River sediments, and although some units of the North Horn pinched out against the flanks of the rising high, other North Horn units continued across the high and buried it. Ever younger sediments (representing, at the least, the Flagstaff (Tf), and later the Colton and Green River Formations) were deposited across the rising upwarp, and these units too were bowed up by slow upwelling of the Arapien.

IV. At some stage, probably after deposition of an Eocene and Oligocene volcanic mantle, erosion removed many of the younger volcanic and sedimentary units deposited across the crest of the fold, and exposed part of the bowed-up thrust plate, represented here by near-vertical and overturned Indianola (Ki). 

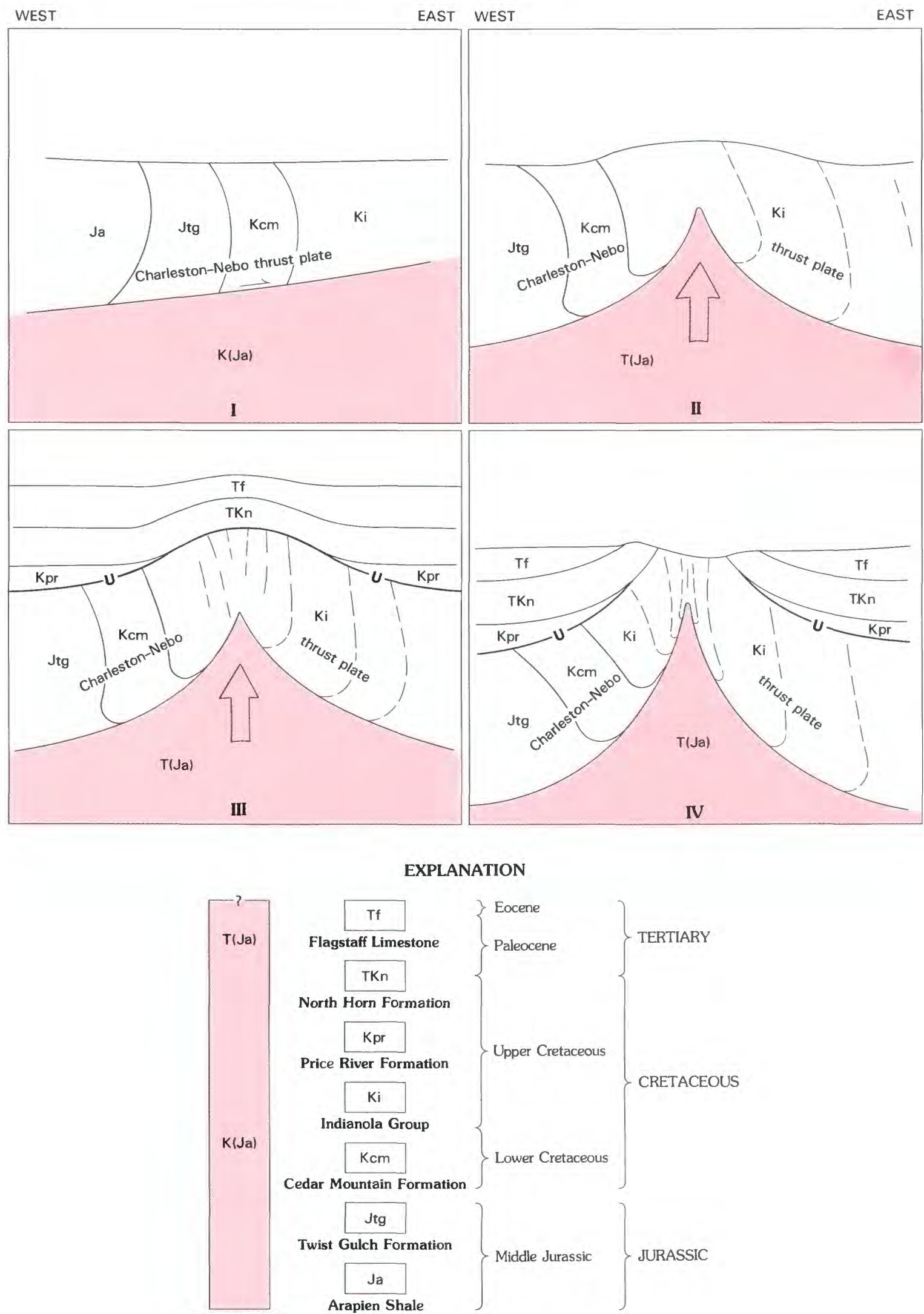

TERTIARY

Price River Formation

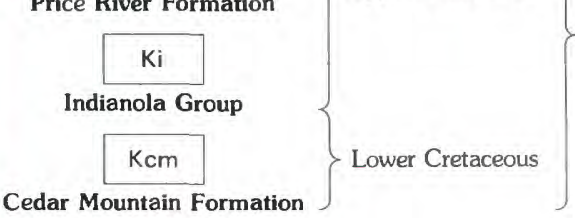

CRETACEOUS

Arapien Shale
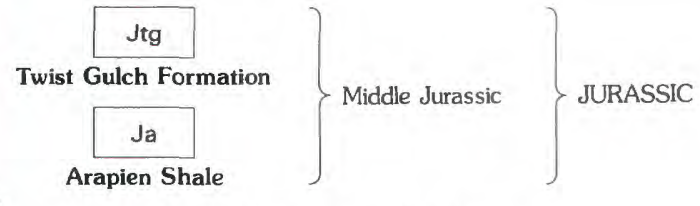

- U_ Angular unconformity 

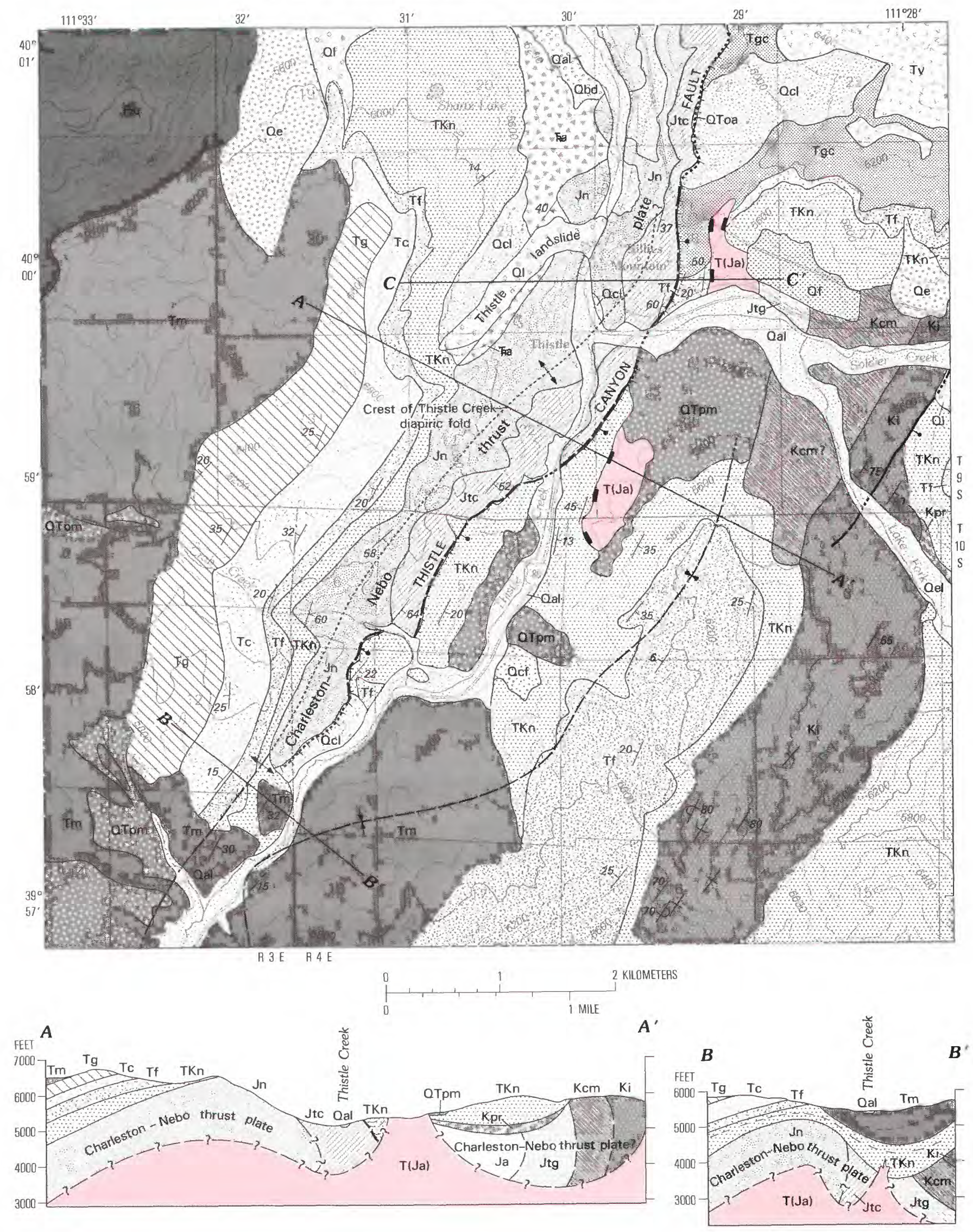
EXPLANATION

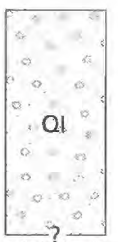

Old landslide deposits
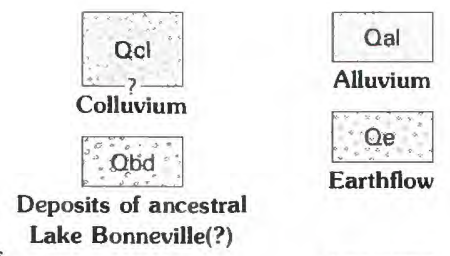

Lake Bonneville(?)

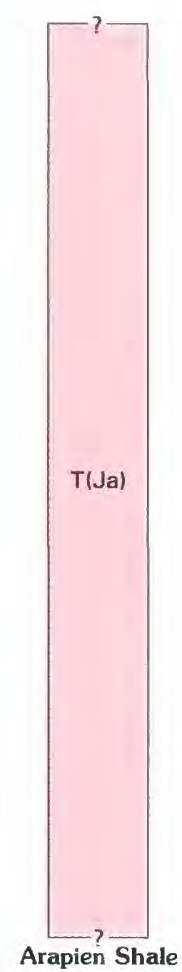

Arapien Shale

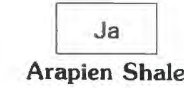

$$
\text { OToa }
$$

$$
T_{m}
$$

$$
\text { Me }
$$

$$
\text { TC }
$$

$$
\text { Tf }
$$

$$
\text { TKn }
$$

$$
\mathrm{Kpr}
$$

$$
\text { (4) } \mathrm{KI}
$$

$$
\mathrm{Kem}
$$

$$
\text { Jtc }
$$

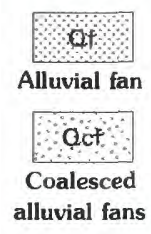

Older alluvium

Moroni Formation

Green River Formation

Colton Formation

Flagstaff Limestone

North Horn Formation

Price River Formation

Indianola Group

Cedar Mountain Formation

Twist Gulch Formation

Twin Creek Limestone

$$
\mathrm{Jn}
$$

Nugget Sandstone (north of Thistle); Navajo Sandstone (south of Thistle)

$$
\begin{gathered}
\text { Ankareh Formation } \\
\text { PAs }
\end{gathered}
$$

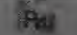

Paleozoic rocks, undivided

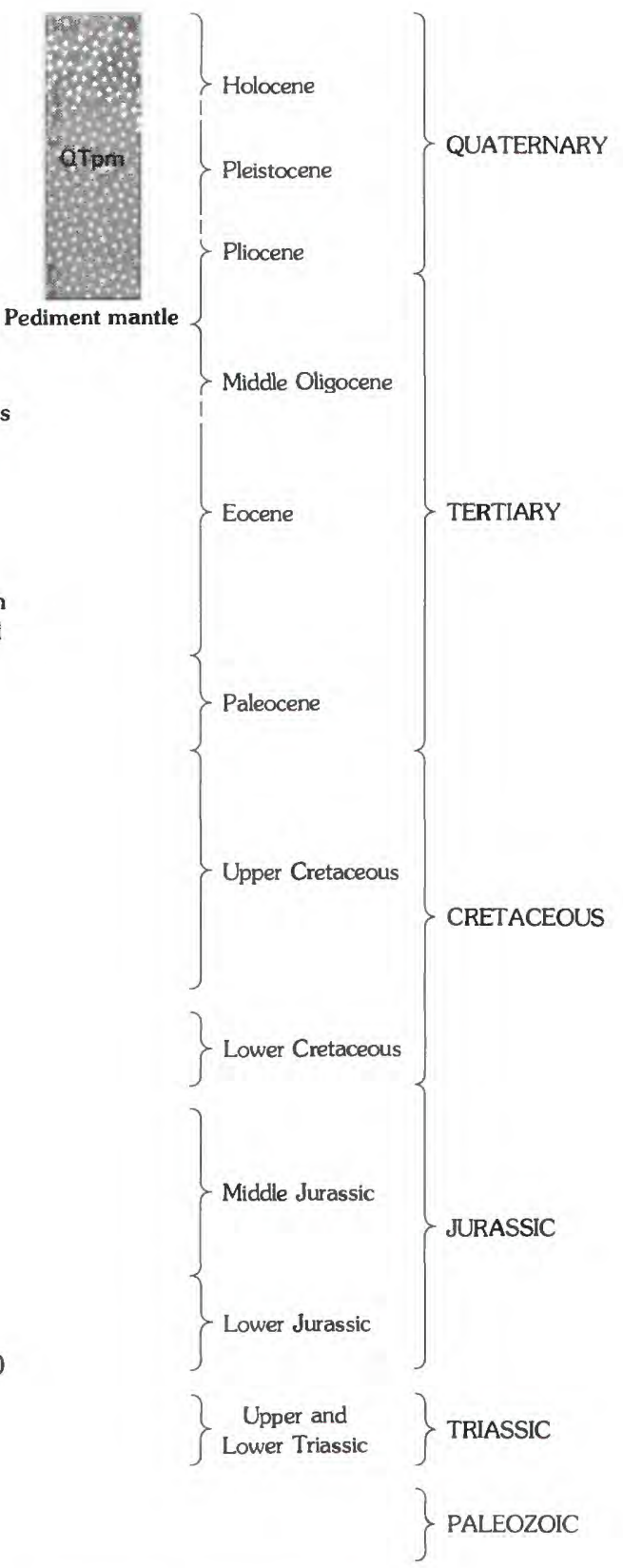

Contact-Approximately located or inferred; dashed and queried in cross section to reflect speculative relations

Intrusive sedimentary contact-Approximately located or inferred; oblongs on intrusive sedimentary unit

Fault-Dashed where approximately located; dotted where concealed; bar and ball on downthrown block

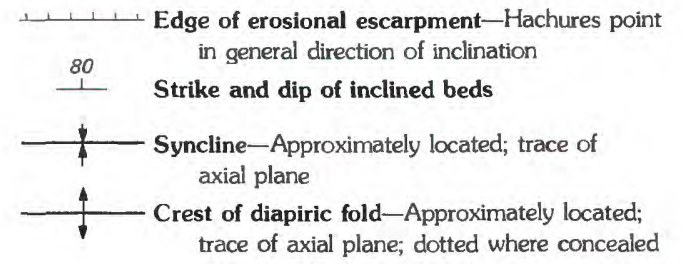

FIGURE 44 (above and facing page).-Geology of Thistle area. (Caption continued on p. 90.) 
FIGURE 44 (previous pages).-Geology of Thistle area. Base modified from U.S. Geological Survey 1:24,000 Billies Mtn (1967), Birdseye (1979), Spanish Fork (1949), and Thistle (1967). Contour interval $200 \mathrm{ft}$. The Charleston-Nebo thrust plate, formed in part by units of the Twin Creek Limestone (Jtc), Nugget Sandstone (Jn) (called the Navajo Sandstone south of Thistle), and the Ankareh Formation ( $\mathrm{ka}$ ), is partly concealed beneath a cover of younger sedimentary rocks. These younger rocks include, in ascending order, the North Horn Formation (TKn), the Flagstaff Limestone (Tf), the Colton Formation (Tc), the Green River Formation (Tg), and the Moroni Formation (Tm).

At one time the thrust plate was completely concealed beneath this younger sedimentary and volcanic mantle. Since then, however, the mantle has been partly breached, exposing parts of the thrust plate, chiefly in and near the valley of Thistle Creek. This younger sedimentary and volcanic cover and the underlying thrust plate appear to have been warped into a northward-trending asymmetric fold. The crest of the fold (shown by a dotted and dashed line) essentially follows the west valley wall of Thistle Creek. West of the crest the younger Tertiary and Cretaceous mantle dips gently westward; east of the crest the beds dip eastward at slightly greater dips. The presence of Arapien exposures ( $\mathrm{T}(\mathrm{Ja})$ ) along the east valley wall of Thistle Creek and along the north valley wall of Soldier Creek suggests that the Arapien both underlies the thrust plate and is responsible for the upwarp of the thrust plate and its overlying mantle of younger sedimentary rocks (cross sections $A-A^{\prime}$ and $B-B^{\prime}$ ). Cross section $C-C^{\prime}$ is in figure 47 .

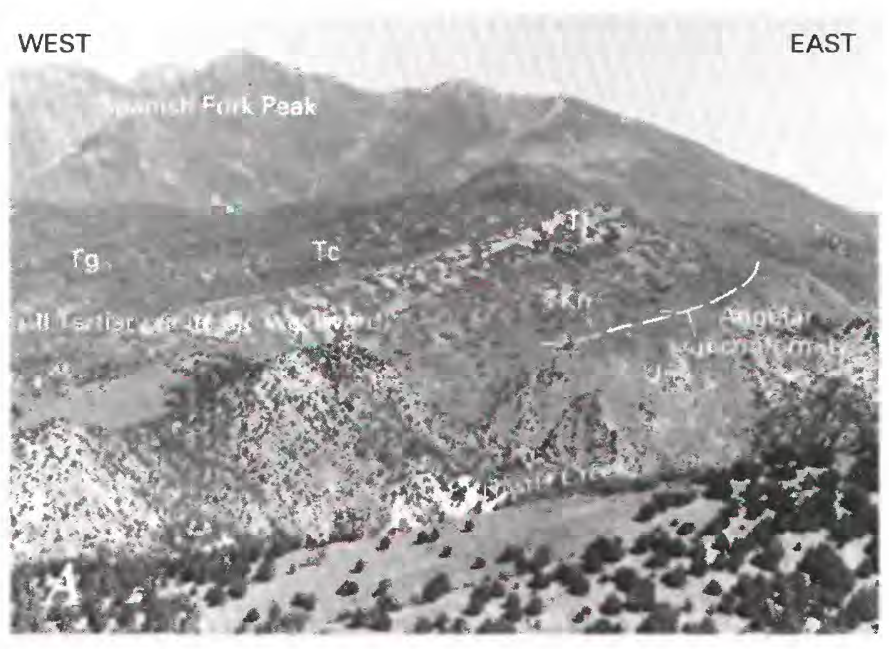

FiguRE 45.-Photographs of Thistle area. See figure 44 for corresponding geologic map. A, View northward of the west valley wall of Thistle Creek. The Nugget Sandstone $(\mathrm{Jn})$, part of the Charleston-Nebo thrust plate, dips steeply eastward. The North Horn Formation ( $T K n)$, dipping gently westward as part of a mantling younger sequence of rocks, unconformably overlies the Nugget. The North Horn Formation, in turn, is conformably overlain by a Tertiary sequence comprising the Flagstaff (Tf), Colton (Tc), and Green River ( $\mathrm{Tg}$ ) Formations. B, View looking northeastward at beds of the Flagstaff Limestone that dip steeply westward. Exposure is north of Soldier Creek and directly east of "Billies Mountain." Light-gray Flagstaff Limestone, commonly underlain by the North Horn Formation, is underlain, in this specific locality, by reddish-brown contorted and crumpled beds of the Arapien Shale ( $T(\mathrm{Ja})$ ). I attribute the upwarp of the Flagstaff Limestone and the absence of units commonly found beneath the Flagstaff to intrusion of the Thistle Creek salt diapir.

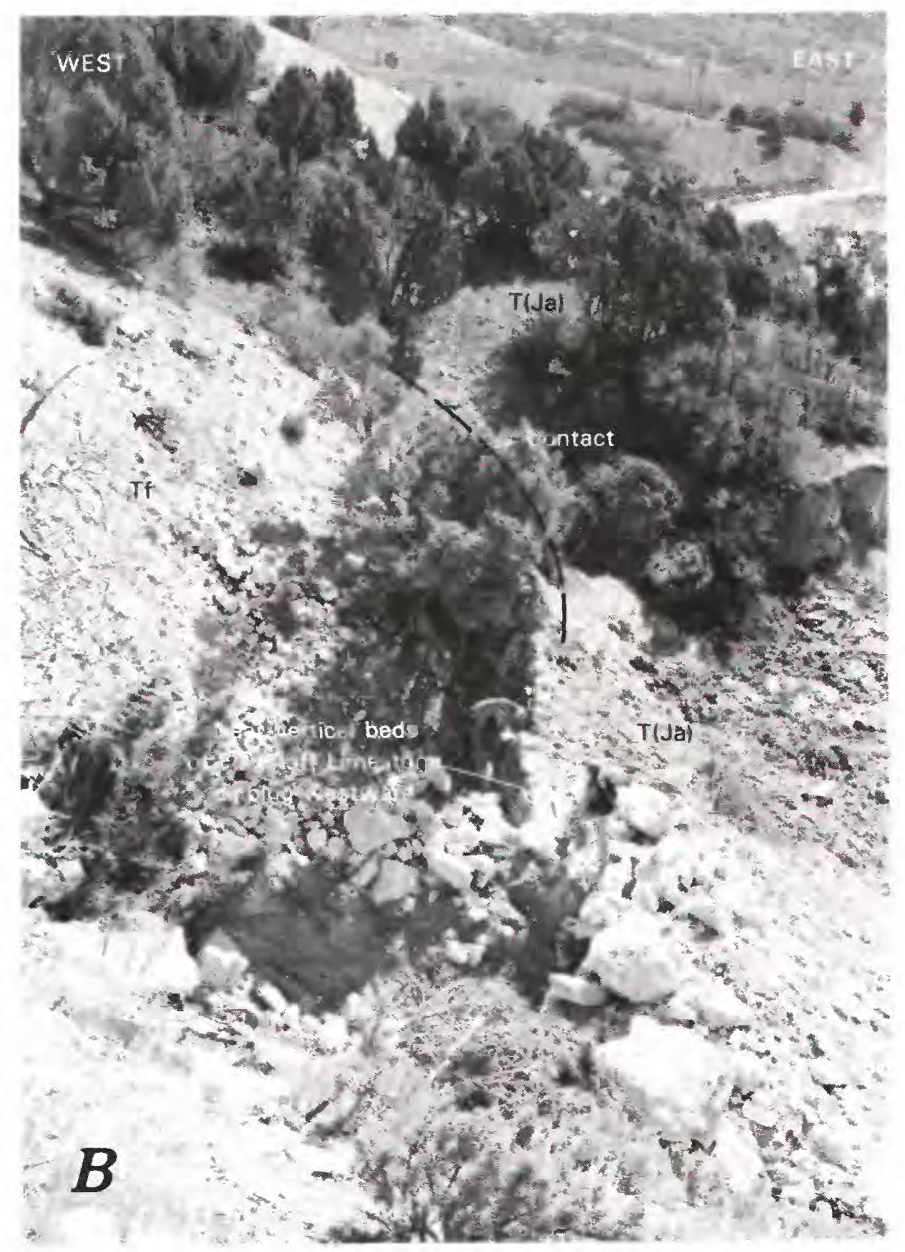



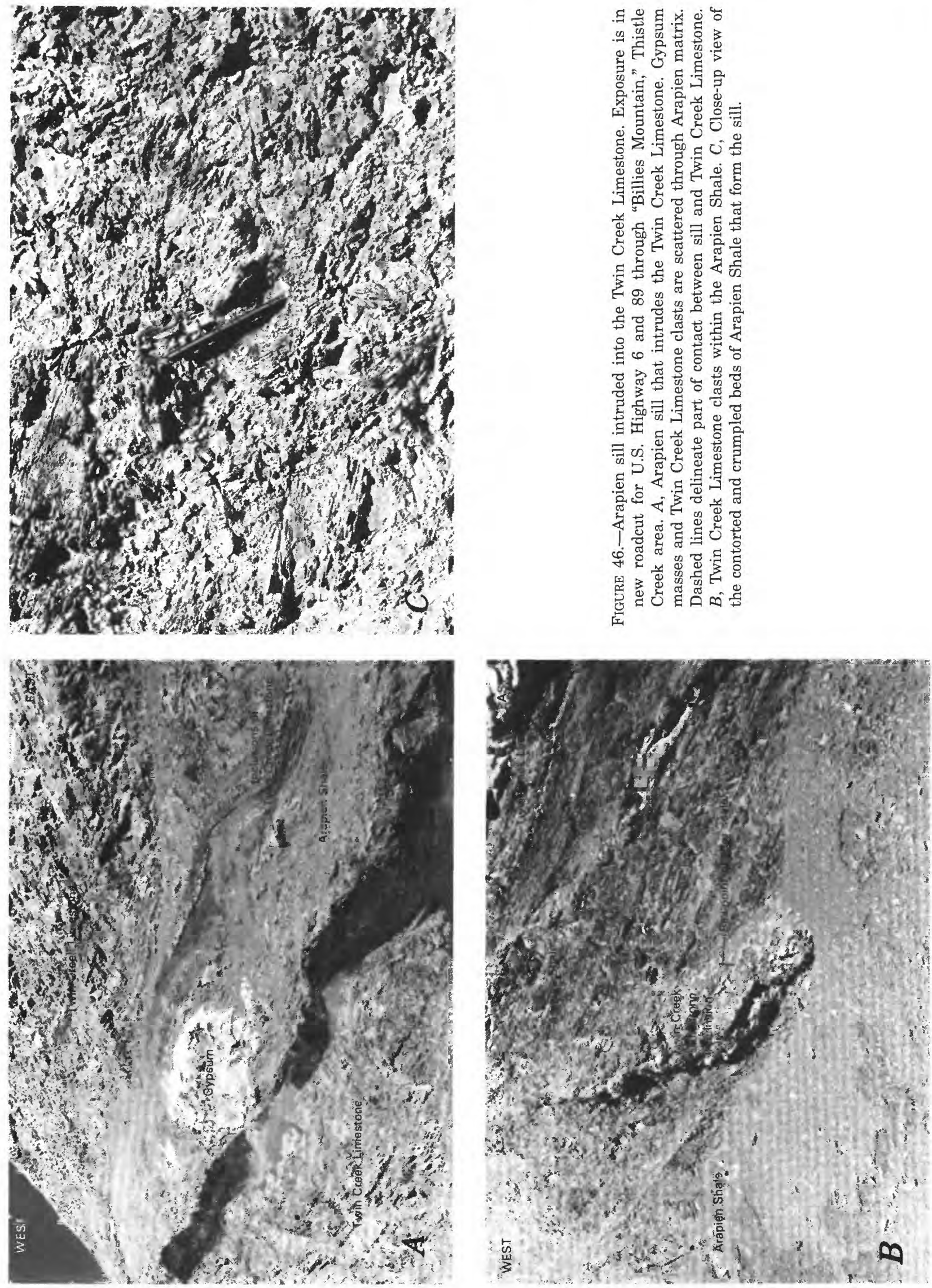
forms the bulk of the Thistle landslide. Directly east of the escarpment cut on the thrust plate, these younger sedimentary and volcanic rocks dip eastward; the same units exposed west of the escarpment dip westward (fig. 45A). Relations between the thrust plate and these overlying sedimentary rocks are well exposed along the west valley wall of Thistle Creek some $6 \mathrm{~km}(3.5 \mathrm{mi})$ north of the small community of Birdseye (A-4). One of the best exposures occupies parts of secs. 5,6 , and 7 , T. $10 \mathrm{~S}$., R. $4 \mathrm{E}$. near the junction of Crab and Thistle Creeks (fig. 44). There, the thrust plate is represented by beds of Nugget Sandstone (Jn) (called Navajo Sandstone south of Thistle, Utah (A-5)) and Twin Creek Limestone (Jtc) that dip eastward about $60^{\circ}$. These beds are unconformably overlain to the east by the North Horn Formation (TKn), which also dips eastward, but at about $20^{\circ}$. A small wedge of eastward-dipping Flagstaff Limestone (Tf) (in the $\mathrm{NE}_{1 / 4}$ sec. 7, T. 10 S., R. 4 E.) conformably overlies the North Horn.

Farther south, near the junction of Aggie and Thistle Creeks, volcanic rocks, part of the Moroni Formation, unconformably overlie the North Horn strata; the Moroni also dips eastward at this point but at about $30^{\circ}$. West of this exposure (as shown on cross section $B-B^{\prime}$, fig. 44), the North Horn (TKn) passes over and conceals the thrust plate, and then dips westward. The North Horn is overlain conformably by the Flagstaff Limestone (Tf), which passes westward beneath ever younger sedimentary beds that also dip westward. This sedimentary sequence is overlain to the west, beyond the area shown in the cross section, by westward-dipping volcanic rocks of the Moroni Formation. It seems clear that the sedimentary rocks were originally overlain by an unbroken blanket of volcanic rocks, now much eroded, that was arched along with the sedimentary rocks.

Structurally, then, the sedimentary and volcanic rocks appear to have been warped into a northtrending asymmetric anticline marked by a steep east flank and a gentle west one. After the beds were arched, erosion removed many of them and in the process exhumed part of the buried thrust plate.

Discussion OF ALternative InTERPRETATIONS

FAULTED TERRAIN

Although all workers in the area agree that the basic structural pattern involves an eroded thrust plate partly buried beneath younger sedimentary rocks, their explanations for the tilted strata differ. Baker (1976), Harris (1954), and Pinnell (1972) concluded that a high-angle, down-to-the-east normal fault, named the Thistle Canyon fault by Harris (1954), separates the younger Cretaceous and Tertiary rocks from the thrust plate (fig. 47A). Presumably the eastward tilt of the younger rocks, east of and juxtaposed against the erosional escarpment, is the result of drag as the east block dropped along the fault. Downthrow to the east is also suggested by the difference in altitude between Flagstaff ( $T f$ ) strata astride the thrust plate west of the escarpment and those Flagstaff strata east of the escarpment. West of the escarpment, the Flagstaff beds are at an altitude of about $6,500 \mathrm{ft}$; east of the escarpment-about 2.5 $\mathrm{km}\left(1 \frac{1 / 2}{1 / 2}\right)$ away-they are at an altitude of about $5,300 \mathrm{ft}$, some $1,200 \mathrm{ft}$ lower.

To the best of my knowledge, no worker has offered any explanation for the westward tilt of those strata that overlie and are west of the erosional escarpment formed on the thrust plate (fig. 45A). A possible explanation involves westward tilting of a discrete fault block as a result of downthrow along a northtrending normal fault, as yet unrecognized, that may extend along the east flank of Loafer Mountain (A-4) (about $1.6 \mathrm{~km}(1 \mathrm{mi})$ west of the area shown in fig. 44). Nor have previous workers offered any explanations for the many localized structural complexities that seem related to intrusive masses of the Arapien Shale. These complexities seem to be products of plastic intrusion.

DIAPIRIC DEFORMATION

I view most of the structural complexity in the Thistle area as a direct result of diapiric deformation that occurred after emplacement of the Charleston-Nebo thrust plate. The localized upwarp of those Flagstaff Limestone beds north of Spanish Fork River (fig. 45B), and the arching of the Tertiary strata, both on a small and on a large scale, seem reasonably explained only by assuming that masses of the Arapien Shale deformed the country rocks long after those rocks were emplaced and consolidated.

The fact that a sedimentary sequence, extending from the North Horn Formation to the Green River Formation, thins toward the crest of the foldessentially the erosional escarpment-implies that a dynamic, ancestral paleo-high continued to rise slowly, impeding sedimentary deposition throughout much of the Late Cretaceous and early Tertiary. As the Moroni Formation is involved in the arching, the high must have persisted at least through middle Oligocene time.

These structural and stratigraphic relations must mean that even as the younger sediments 


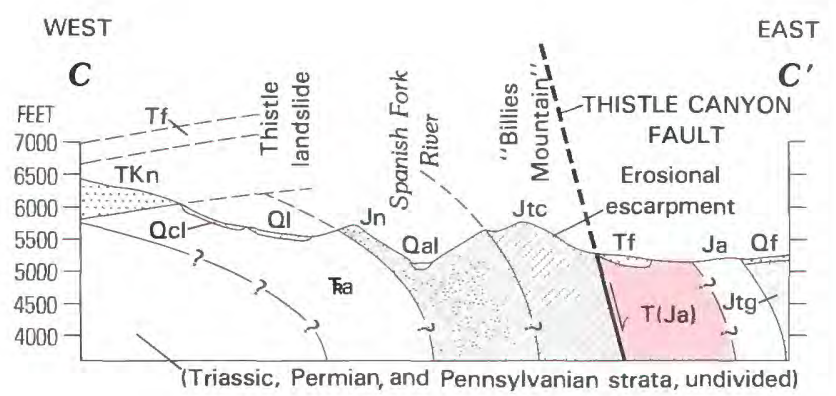

A

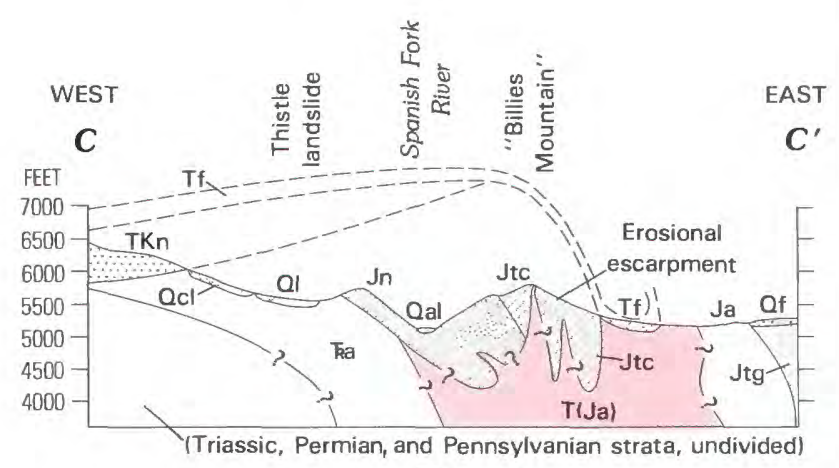

B

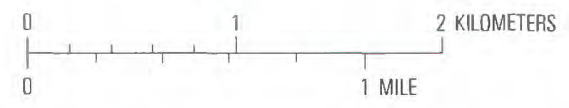

Figure 47.-Two alternative interpretations of geologic relations in Thistle area. Line of cross section C-C' is shown in figure 44, geologic map of the Thistle area. Contacts are dashed and (or) queried where relations are speculative. Quaternary units: Old, landslide deposit; Ocl, colluvium; Of, alluvial fan; Qal, alluvium. Jtg, Jurassic Twist Gulch Formation. A, The Thistle Canyon fault, downthrown to the east, separates the younger Cretaceous and Tertiary sedimentary rocks (represented by the Flagstaff Limestone (Tf)) from the Charleston-Nebo thrust plate, represented by beds of the Twin Creek (Jtc), Nugget (Jn), and Ankareh ( a) Formations. B, A mass of Arapien Shale ( $\mathrm{T}(\mathrm{Ja}))$ intruded and raised part of the Charleston-Nebo thrust plate, and in so doing arched the overlying younger Cretaceous and Tertiary sedimentary and volcanic rocks into a north-trending asymmetric fold. The eastward-dipping Flagstaff (Tf) strata, directly east of the erosional escarpment, are part of the fold's east flank. The westwarddipping North Horn strata (TKn), west of the escarpment, are part of the fold's west flank.

The thinning of all younger sedimentary units (here represented by the North Horn (TKn) and Flagstaff (Tf) Formations) toward the crest of the fold suggests that a diapiric fold, concealed beneath the thrust plate, has been growing at a slow, almost imperceptible rate impeding sedimentary deposition.

accumulated, a diapiric fold-the Thistle Creek diapiric fold-began to move upward beneath the thrust plate.
Many of the diapiric folds in central Utah are readily recognizable by the juxtaposition of contorted Arapien Shale masses against vertical to overturned beds, commonly of the Indianola Group. In the Thistle area, by contrast, a diapiric fold is indicated by strata arched asymmetrically over the escarpment cut on the Charleston-Nebo thrust plate. The eastward-dipping North Horn (TKn), Flagstaff (Tf), and Moroni (Tm) strata east of the erosional escarpment are in the east flank of the fold; the same strata west of the escarpment are in the west-dipping flank. In my view, the opposing dips of the strata and the difference in altitude between Flagstaff strata west and east of the escarpment merely reflect the configuration and asymmetry of the fold draped across the escarpment (fig. 47B).

I suggest that the erosional escarpment, formed on the thrust plate, was originally buried beneath nearly horizontal North Horn and younger strata. As a diapiric fold developed beneath the thrust plate, it raised the plate, and in so doing arched the overlying younger rocks. Erosion has since removed the crestal part of the arched sheet of North Horn and younger rocks and exhumed part of the escarpment.

\section{HJORTH CANYON DIAPIRIC FOLD}

Part of a northeast-trending diapiric fold (fig. 16, 9) is exposed in Hjorth Canyon (A-5) (secs. 15, 16, 21, and 22, T. 11 S., R. 4 E.), some $6 \mathrm{~km}\left(3 \frac{1}{2} \mathrm{mi}\right)$ north of Indianola (B-5) (fig. 2). This fold was first recognized and called the "Hjork Creek dome" by Runyon (1977b, p. 76), who noted that the structure "is actually an elongated dome rather than a circular one***and is illustrated $* * *$ as a plunging anticline."

\section{GEOLOGIC SETTING}

Critical exposures, along the north wall of Hjorth Canyon, consist of a narrow band of highly contorted Arapien Shale that trends about N. $40^{\circ}$ E., bounded on each flank by beds of the Twist Gulch Formation (fig. 48). Exposures are poor, but I suspect that beds of the Cedar Mountain Formation are stratigraphically above the Twist Gulch beds; in figure 48 I have mapped these Cedar Mountain(?) beds with Twist Gulch strata.

The Twist Gulch and Cedar Mountain(?) strata are anomalously thin; the thickness of the Twist Gulch Formation in the Hjorth Canyon area is less than 450 $\mathrm{m}(1,500 \mathrm{ft})$. Elsewhere in this general area the Twist Gulch is about $915 \mathrm{~m}(3,000 \mathrm{ft})$ thick (Khin, 1956, p. 34). This unusual thinning has been recognized by 

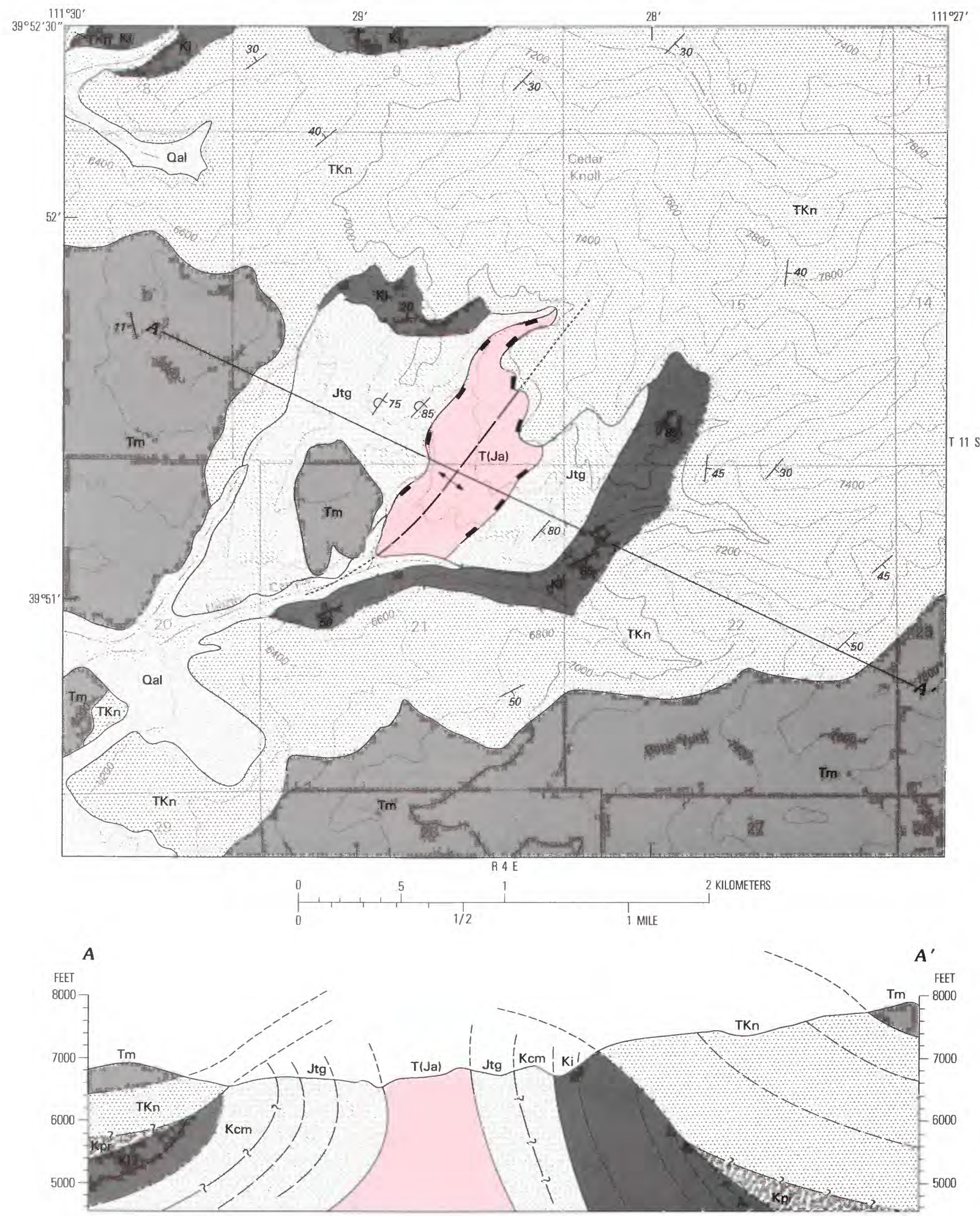


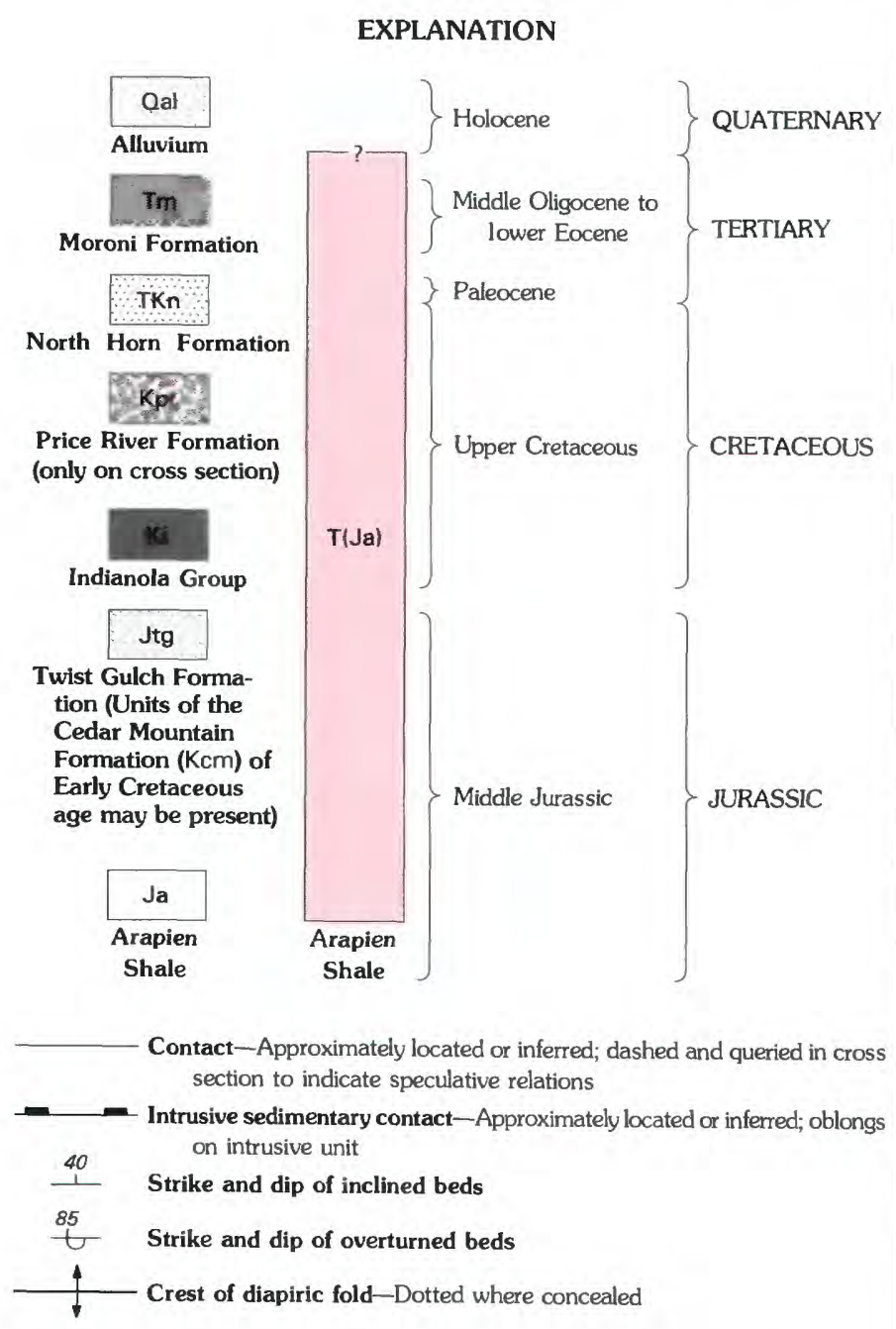

FIGURE 48 (above and facing page)-Geology of Hjorth Canyon area showing part of northeast-trending Hjorth Canyon diapiric fold. Base modified from U.S. Geological Survey 1:24,000 Indianola (1967). Contour interval $200 \mathrm{ft}$. Beds of the Twist Gulch Formation flank the core-a northeast-trending mass of Arapien Shale of the diapiric fold. Twist Gulch strata on both flanks of the fold dip steeply southeast; those on the northwest flank are overturned. Overlying North Horn strata reflect the general configuration of the fold, as do the volcanics of the Moroni Formation (cross section $A-A^{\prime}$ ). Arapien Shale as unit Ja is listed for completeness but is not shown, as such, on the map.

previous workers. Thus, Runyon (1977b, p. 67) attributed this "drastic thinning" to "drag faulting caused by the diapiric upwelling of the underlying Arapien***." Pinnell (1972, p. 97), however, attributed it to "*** *apid facies changes in***environments of deposition or of Laramide thrusting."

Those Twist Gulch beds that form the northwest flank of the fold strike about N. $40^{\circ}$ E., are vertical or overturned to the northwest, and so dip about $85^{\circ}$ to the southeast. Twist Gulch beds that form the southeast flank of the fold are right-side-up and dip southeastward between $80^{\circ}$ and $85^{\circ}$. The outermost flanks of the fold are formed by units of the Indianola Group that dip about $20^{\circ} \mathrm{NW}$. along the northwest flank, and about $85^{\circ} \mathrm{SE}$. along the southeast flank.

All beds that form the fold are unconformably overlain either by moderately dipping strata of the North Horn Formation or by volcanic units of the Moroni Formation. Here too, as in the Dry Hollow (A-5) fold, these younger beds appear to have been arched during one or more upward movements of the underlying fold. Thus, those North Horn beds that overlie the northwest flank of the fold dip about $10^{\circ} \mathrm{W}$; those North Horn beds that overlie the southeast flank dip $30^{\circ}$ to $50^{\circ} \mathrm{SE}$. These southeast dips persist southeastward for about $1.6 \mathrm{~km}(1 \mathrm{mi})$, after which the North Horn beds pass beneath volcanic units of the Moroni Formation. Although attitudes of the Moroni beds are difficult to determine, I believe that they, too, reflect the configuration of the fold. Southeast of the exposures already described, near Little Clear Creek (B-5), Moroni beds dip northwest. This northwest dip of the Moroni strata reflects the northwest flank of the Little Clear Creek diapiric fold, which also trends northeast, and thus is parallel to and about $3 \mathrm{~km}(2 \mathrm{mi})$ southeast of the Hjorth Canyon fold (fig. 16).

\section{DISCUSSION}

I attribute the anomalous thinning of the Twist Gulch, Cedar Mountain(?), and most likely the Indianola strata, in the Hjorth Canyon area, to the imperceptible upward movement of the salt diapir during much of the time these units were being deposited.

The deformed rocks in Hjorth Canyon suggest three distinct diapiric episodes. During the first episode, once near-horizontal Twist Gulch, Cedar Mountain, and Indianola strata were bowed up and locally turned over as the Hjorth Canyon salt daipir surged upward to form a mushroom-shaped diapiric fold. This upward surge must have occurred at some time after Indianola strata were deposited and consolidated, in essence, during the Late Cretaceous, possibly after Santonian but before Campanian time. Subsequently, removal of salt partly destroyed this fold, and erosion then reduced it to a surface of low relief on which Price River sediments were deposited; these were subsequently overlain by North Horn sediments. As Price River strata are missing from this specific locality, I assume that they pinched out locally against the flanks of the slowly rising fold. 
The second diapiric episode, represented by the arched beds of the North Horn, must have occurred at some time during the early Tertiary, for North Horn deposition continued at least into the Paleocene. The fact that the arched North Horn dips away from the crest of the fold, represented by the northeast-trending band of Arapien strata (fig. 48), implies that the upward surge of the diapir occurred in the same place and had the same trend as the previous fold. As North Horn strata are unconformably overlain by the volcanic rocks of the Moroni Formation, I assume that whatever younger Tertiary sedimentary strata were deposited, following the formation of the North Horn, either pinched out against the flanks of the rising fold or were eroded before volcanics of the Moroni spread across the area.

The arched Moroni represents the third diapiric episode. Presumably, a renewed upward surge of the salt diapir bowed up these once near-horizontal flows. Again, the attitudes of the Moroni rocks, dipping away from the crest of the fold, indicate that this renewed surge must have occurred in the same place and with the same trend as the two ancestral folds. This third surge must have come at some time after middle Oligocene time for the Moroni is of late Eocene to middle Oligocene age.

\section{LITTLE CLEAR CREEK DIAPIRIC FOLD}

\section{GEOLOGIC SETTING}

Little Clear Creek (B-5) has cut a deep, narrow canyon into the crest of a major diapiric fold (fig. 16, 8) that trends about N. $45^{\circ} \mathrm{E}$. The fold can be traced from the center of sec. 26 , T. 11 S., R. 4 E. to the northwest corner of sec. 5, T. 11 S., R. 5 E., where it passes into a large graben known as the Dairy Fork (A-5) graben (fig. 49).

Twist Gulch strata form the crest and part of both flanks of the fold. The flanks dip steeply away from the crest for much of the fold's exposed length. Thus, those Twist Gulch rocks that are part of the fold's northwest flank dip about $80^{\circ} \mathrm{NW}$; comparable dips, but to the southeast, mark the fold's southeast flank. Only a narrow segment of Twist Gulch strata crops out along the fold's northwest flank; much of that flank is concealed beneath beds of either the North Horn or Moroni Formations that dip northwestward at moderate angles, and that unconformably overlie the steeply dipping Twist Gulch strata. The wellexposed southeast flank of the fold includes units of the Twist Gulch and Cedar Mountain Formations and the Indianola Group. All these strata dip at high angles, commonly to the southeast, but locally some beds are vertical or are overturned and so dip northwestward. These steeply inclined units are unconformably overlain by Price River and North Horn strata that dip about $35^{\circ} \mathrm{SE}$.

Exposures are inadequate to determine whether any of the units involved thin toward the crest of the fold.

\section{DISCUSSION}

I interpret the geologic relations in Little Clear Creek, as in Dry Hollow, and Hjorth Canyon, to indicate three distinct episodes of diapiric deformation.

During the first episode an upward surge of the causative salt diapir bowed up the Twist Gulch, Cedar Mountain, and Indianola strata to form a mushroom-shaped fold. Collapse of that fold, presumably as a result of withdrawal of salt, and subsequent erosion left a surface of low relief on which the Price River and North Horn were deposited.

During the second episode a second upward surge of the causative diapir arched this Price River and North Horn sequence. Inadequate exposures hinder any clear interpretation of what followed. Perhaps the arched Price River and North Horn sequence was eroded to a surface of low relief on which Flagstaff sediments were deposited. In time, these Flagstaff strata were buried beneath younger beds, possibly Colton and Green River strata. Erosion, after Green River time, resulted in a moderately dissected surface onto which volcanic flows of the Moroni Formation were extruded.

At some time after volcanics of the Moroni were emplaced, the salt diapir surged upward for a third time and warped up the volcanic rocks. The beds deformed by the diapir during this third episode occupy the same site and have the same trend as those older beds deformed during the previous episodes, implying that once again the diapir moved up the same conduit it followed in the previous two episodes.

As volcanic rocks of the Moroni Formation (formed between late Eocene and middle Oligocene time) are involved in this last episode of diapirism, the diapiric

Figure 49 (facing page).-Geology of Little Clear Creek area. Base modified from U.S. Geological Survey 1:100,000 Nephi (1981). Contour interval $250 \mathrm{~m}$. Little Clear Creek and West Lake Fork follow the crest of the Little Clear Creek diapiric fold. At its north end, the fold passes into the Dairy Fork graben. These relations suggest that part of the causative salt diapir was removed, and the overlying beds then subsided into the resultant void or voids to form the graben. Arapien Shale as unit Ja is listed for completeness but is not shown, as such, on the map. 

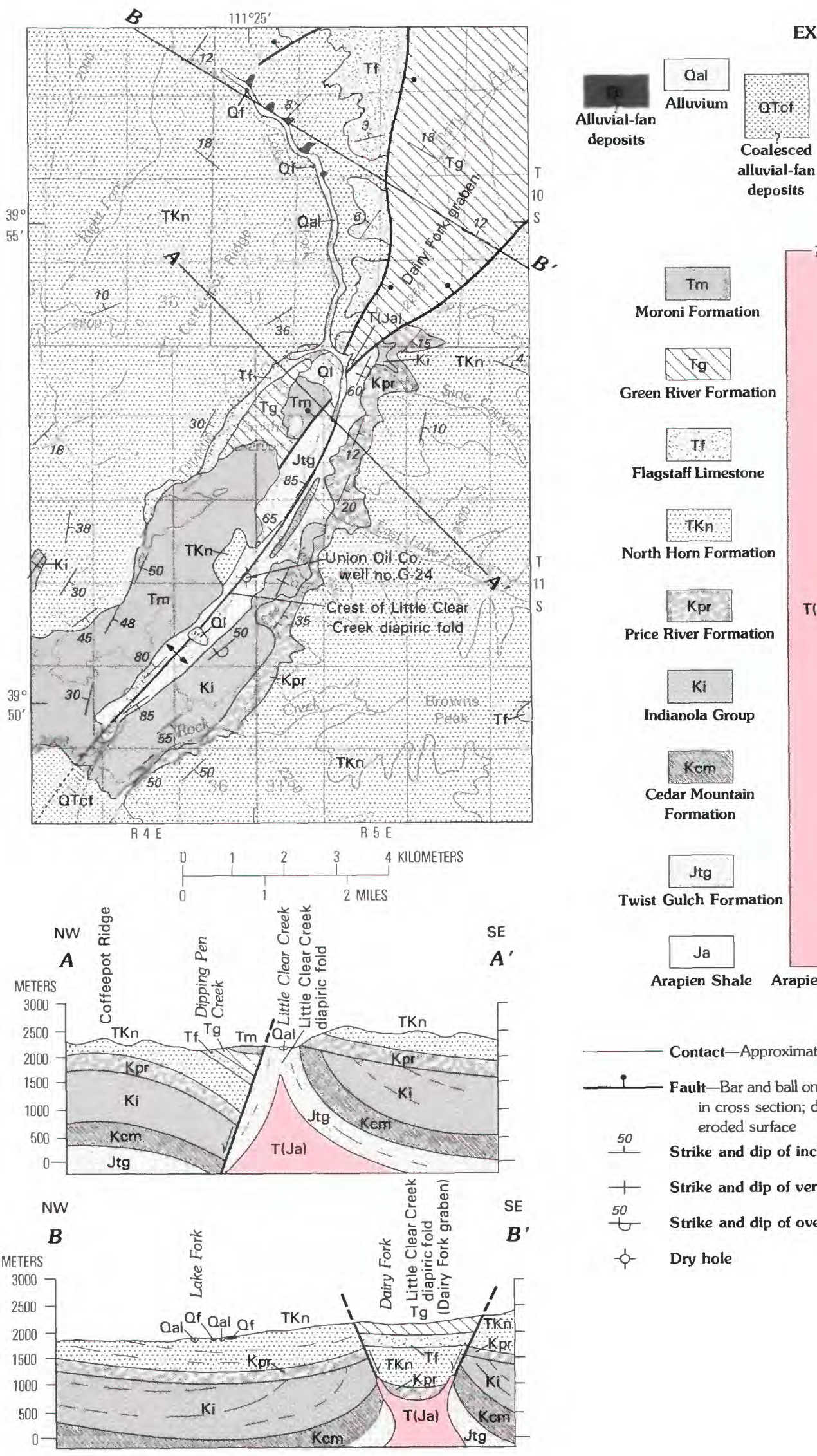

EXPLANATION
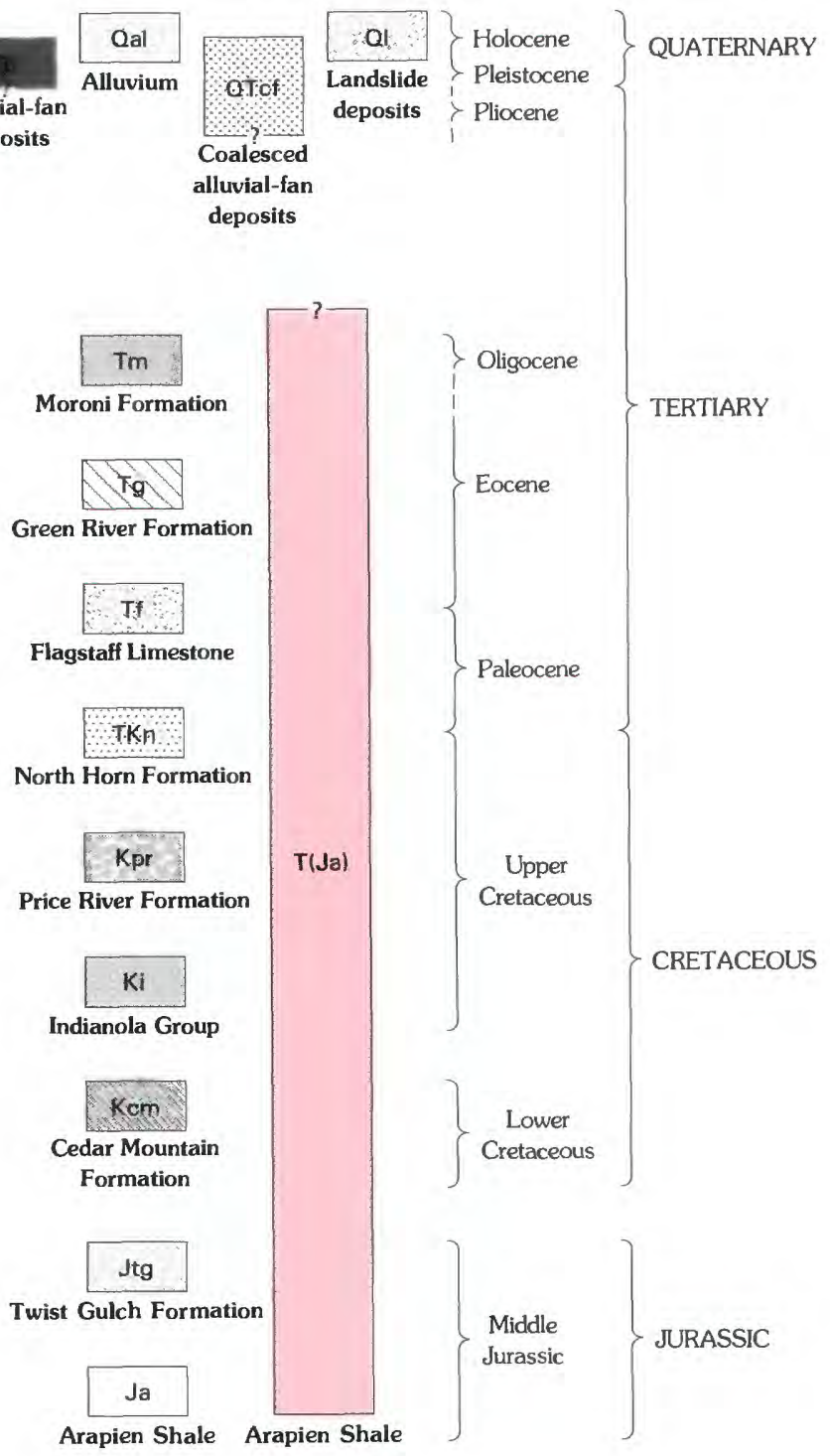

Contact-Approximately located or inferred

$\cdot$

Fault-Bar and ball on downthrown block; barb shows downthrown block in cross section; dashed in cross section where reconstructed above eroded surface

$\stackrel{50}{1}$ Strike and dip of inclined beds

+ Strike and dip of vertical beds

50

Strike and dip of overturned beds

- + Dry hole 
folds presumably developed at some time during or after middle Oligocene time.

Near Smiths Reservoir (where Side Canyon joins Lake Fork), the fold passes northeastward into a northeast-trending graben, the Dairy Fork graben of Merrill (1972, p. 79), that is collinear with the fold. Seemingly, the graben represents collapse of the crestal part of the Little Clear Creek fold as a result of salt dissolution (cross section $B-B^{\prime}$, fig. 49).

Union Oil Company drilled its well, No. G-24, along the crest of the fold in the NE1/4 sec. 24 , T. 11 S., R. 4 E. (fig. 49). The well drilled into the Arapien Shale but did not pass through it.

\section{FAIRVIEW DIAPIRIC(?) FOLD}

The east fork of Sanpete Valley, essentially that sector of Sanpete Valley that extends from Ephraim (E-4) northeastward to and beyond Milburn (B-5), is flanked on the east by the imposing, westward-facing Wasatch monocline. I believe that the Wasatch monocline (E-5), much like the Valley Mountains monocline $(\mathrm{G}-2)$, was formed when salt was removed from a major salt diapir that lies at the foot of the monocline. Removal of the salt resulted in near-horizontal beds being let down to form the monocline (Witkind and Page, 1984).

Much evidence, in the form of upturned Cretaceous and Jurassic beds, and Arapien exposures, suggests that a major diapir, the Sanpete-Sevier Valley diapir, underlies the southern part of Sanpete Valley. Near Ephraim, the diapir appears to bifurcate, with one branch extending northward into the west fork of Sanpete Valley, and the other extending northeastward into the east fork of Sanpete Valley. The structural complexity along the east flank of the Gunnison Plateau near Wales Gap (D-4) supports the presence of the west branch of the diapir, for which I have retained the name Sanpete-Sevier Valley diapir. By contrast, mainly the downwarp of strata to form the north end of the Wasatch monocline suggests the presence of the east branch of the diapir, which I call the Fairview diapir(?) (fig. 16, 7). These downwarped strata dip westward at about $20^{\circ}$. At the north end of the Wasatch monocline, near the head of the east fork of Sanpete Valley east of Indianola, the strata are flexed up and dip eastward as part of the east flank of the Little Clear Creek (B-5) diapiric fold. These upwarped strata mark the northernmost extent of the Wasatch monocline.

The south half of the Wasatch monocline, thus, may have been formed by the removal of salt from the Sanpete-Sevier Valley diapir, whereas the north half may have been formed by the removal of salt from the Fairview diapir(?).

I propose that the Fairview diapiric(?) fold extends in a generally northeastward direction from Ephraim (E-4), through Mount Pleasant (D-5), Fairview (C-5), Oak Creek (C-5), and Milburn (B-5), to end near the head of the east fork of Sanpete Valley. The fold, thus, is about $52 \mathrm{~km}$ ( $32 \mathrm{mi}$ ) long, and, in detail, trends about N. $30^{\circ}$ E. from Ephraim to Mount Pleasant, and then bends to trend almost due north from Mount Pleasant through Fairview and Milburn to its end east of Indianola.

\section{GEOLOGIC SETTING}

Much of the following discussion about the Fairview diapiric(?) fold is speculative; the available ground evidence is sparse and contradictory. Some evidence hints at the existence of a diapiric fold beneath the east fork of Sanpete Valley. Thus, for example, test wells and seismic reflection profiles indicate that near Mount Pleasant (D-5) an inordinately large mass of Arapien Shale underlies the surficial deposits that floor Sanpete Valley. Furthermore, the downwarp of the Cretaceous and Tertiary sedimentary strata that form the north end of the Wasatch monocline, essentially near and north of Milburn (B-5), seems most readily explained by dissolution of salt from a diapir-the Fairview diapirconcealed beneath the surficial deposits.

At the north end of the east fork of Sanpete Valley, coalesced alluvial fans partly bury westward-dipping, cuesta-like masses of Green River strata that have been much broken. Many of the smaller Green River masses are intensely brecciated, and locally appear as chaotically disrupted masses. A few of the larger masses, however, although greatly disrupted, still appear as entities. Runyon (1977b, p. 76) interpreted these disrupted masses to be part of a collapsed, dome-shaped diapir, which he called the "North San Pitch River Valley diapir."

Strata exposed west of the east fork of Sanpete Valley also dip westward at angles that range from about $15^{\circ}$ to $20^{\circ}$.

Directly west of the north end of the east fork of Sanpete Valley, North Horn, Flagstaff, Colton, and Green River strata are warped to form a southplunging syncline best exposed east of Indianola (B-5) along the north side of Indian Hollow.

\section{DISCUSSION}

At the north end of the Wasatch monocline the Cretaceous and Tertiary beds flex down, and this 


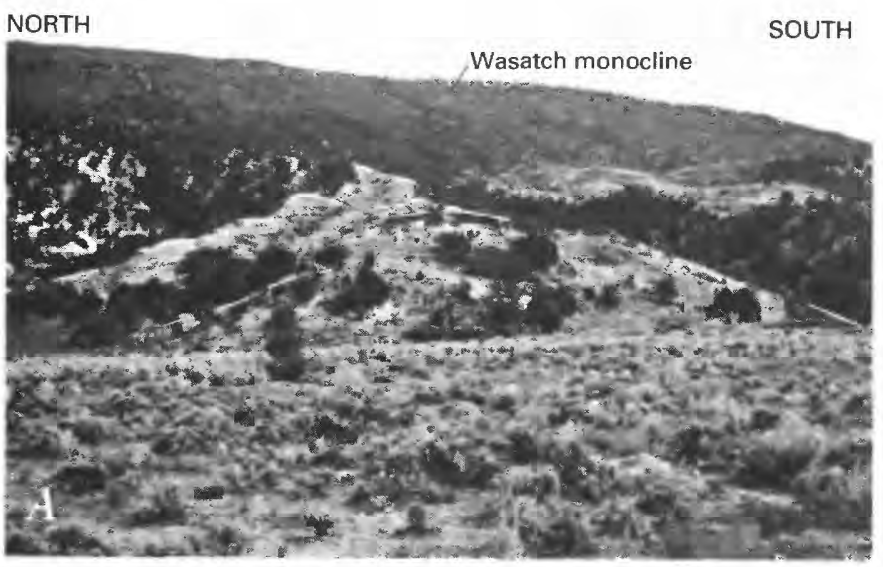

FiguRE 50,--Landslide and earthflow phenomena along Wasatch front. A, View eastward of earthflow (dashed outline), typical of those exposed along base of Wasatch monocline; about $6 \mathrm{~km}$ (4 mi) southwest of Ephraim. Detritus derived chiefly from the Colton Formation forms earthflow. The earthflow was emplaced at some time after the Wasatch monocline was formed. As salt was removed from the causative Sanpete-Sevier Valley salt diapir, which underlay Sanpete Valley, those sedimentary strata that overlay the diapir subsided into the resultant voids. The Wasatch monocline formed as a result of this

downwarp, in my opinion, is the most telling bit of evidence supporting the existence of the Fairview diapiric(?) fold. Elsewhere, as in the Sixmile Canyon $(\mathrm{F}-4)$ area of the Wasatch Plateau, where the toe of the monocline has been breached, or in the Red Canyon area (E-2) of the Valley Mountains, where the Valley Mountains monocline has been breached, the complex structural relations exposed in the breached areas seem reasonably explained only by invoking the repeated growth and collapse of causative salt diapirs (Witkind and Page, 1984, p. 152-155). Those causative diapirs, now concealed beneath surficial deposits, were once concealed beneath near-horizontal beds. Dissolution of salt from the diapirs resulted in subsidence of the Arapien mudstones into the newly formed voids, thus removing support from the near-horizontal beds. Inevitably, these strata failed and flexed down to form the monoclines. In my view, then, the process that formed the Wasatch and Valley Mountains monoclines was not differential uplift but rather subsidence, stemming from dissolution of salt in a system of diapirs including the proposed Fairview diapir(?).

Runyon (1977b, p. 76), discussing his North San Pitch River Valley diapir, also attributed its formation to subsidence as a result of dissolution of salt. I agree with Runyon about the existence of a diapir in the east fork of Sanpete Valley, but disagree with his interpretation that the jumble of disrupted Green

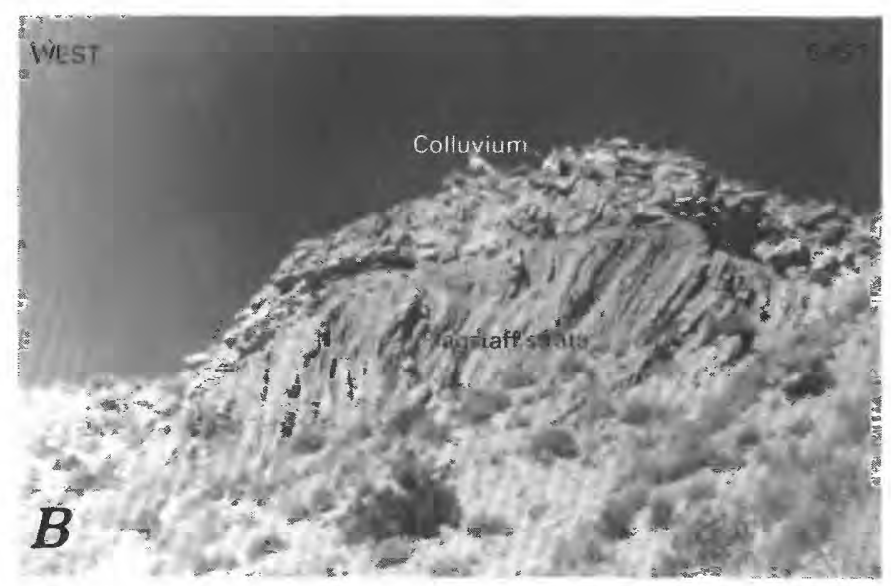

subsidence; probably the earthflow occurred shortly after in response to that downwarp. $B$, View northward near mouth of north valley wall of Manti Canyon. This exposure, about 0.8 $\mathrm{km}(1 / 2 \mathrm{mi})$ south of Temple Hill-the large detachment block composed of Green River and Crazy Hollow strata on which the Mormon temple at Manti is constructed-shows westwardinclined drag folds (directly beneath the colluvium) that probably stem from the valleyward movement of comparable slide blocks that have since been eroded.

River rocks at the north end of the east fork of Sanpete Valley marks the site of a dome-shaped collapsed diapir. I believe rather that these brecciated Green River masses are ancestral landslide blocks that slid valleyward as the Wasatch monocline developed.

The many large earthflows (fig. 50A), landslides, detachment blocks, and other mass-wasting deposits that mantle and flank the lower slopes of the Wasatch monocline probably stem from this downwarp. Most of these deposits consist of a chaotic jumble of fragmented rocks, derived chiefly from the breakup of the Colton Formation, which slid valleyward off the tilted beds of the Flagstaff Limestone. Locally, however, large unbroken detachment blocks slid westward and came to rest at or near the base of the monocline. Perhaps the best example is Temple Hill, in Manti (E-4), on which the town's striking Mormon temple is built. This block slid westward off the monocline, crossed steeply inclined Flagstaff and Colton strata (fig. 50B), and came to rest on the valley floor $150 \mathrm{~m}(500 \mathrm{ft})$ west of the monocline (fig. 51). The block, a crude oblong, trends west, and is about $1.4 \mathrm{~km}(0.9 \mathrm{mi})$ wide. It rises some $105 \mathrm{~m}$ (350 $\mathrm{ft}$ ) above the adjacent valley floor, and is composed almost wholly of limestone beds of the Green River. These beds of Green River are overlain, along the north face of the block, by conglomerate beds of the Crazy Hollow Formation that were obviously carried "piggyback" on the Green River. 


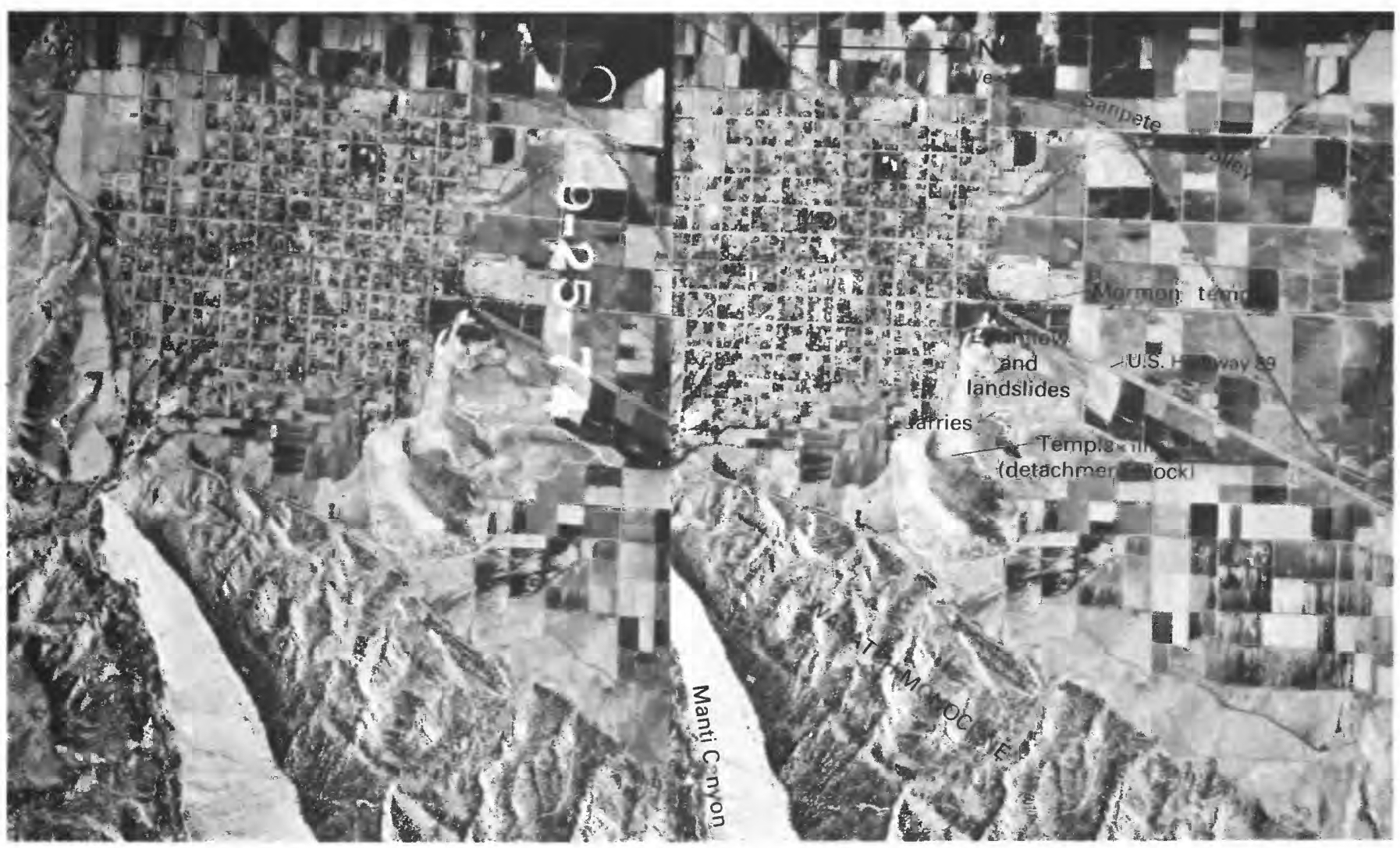

FIGURE 51.-Stereographic vertical aerial photographs of the Temple Hill area, Manti, Utah. Temple Hill, a detachment block composed of Green River and Crazy Hollow strata, slid valleyward (westward) off the Wasatch monocline. From 1877 to 1888, early Mormon pioneers quarried oolitic limestone from the Green River Formation and constructed the temple at Manti. Some of the quarries used as a source of building stone are shown on the photograph; others are farther north near Ephraim.

Still another detachment block, also composed of Green River and Crazy Hollow strata, is near the ancestral Willow Creek (G-3) area (Witkind, 1981). The presence of Crazy Hollow strata on these slide blocks implies that the downwarp responsible for the monocline and the accompanying sliding occurred during or after the late Oligocene.

Some ground evidence, however, seemingly contradicts my view that a diapiric fold is concealed beneath the east fork of Sanpete Valley. So, Green River strata west of the east fork of Sanpete Valley dip westward (Witkind and Weiss, 1991). If, as I propose, dissolution of salt from a concealed diapir caused subsidence of overlying near-horizontal strata to form the westward-facing Wasatch monocline, one would expect that strata west of the diapir would dip eastward and so form an eastward-facing monocline: in essence, paired, facing monoclines should result from the partial failure of the causative diapir. Such is not the case in this specific locality, and the westward dip of those rocks west of the east fork of Sanpete Valley puzzles me. One possible explanation is that these strata west of the east fork of Sanpete Valley were tilted up to a westward dip at some time after the monocline was formed. Some support for this view is given by the south-plunging syncline near Indian Hollow. As Green River strata occupy the center of the syncline, the implication is strong that the deformation responsible for the development of the syncline occurred at some time after Green River strata were flexed down to form the Wasatch monocline.

\section{WEST HILLS DIAPIRIC(?) FOLD}

West Hills (D-2), and Long Ridge (B-2) to the north, are low, narrow, north-trending ridges composed of sedimentary and volcanic rocks that form the west side of Juab Valley (C-2). I suspect that a major salt diapir underlies the West Hills (fig. 16, 5).

\section{GEOLOGIC SETTING}

Structurally, the West Hills are an elongate upwarp that trends about N. $20^{\circ} \mathrm{E}$. and is about $24 \mathrm{~km}$ (15 mi) 
long by $5 \mathrm{~km}(3 \mathrm{mi})$ wide. The fold extends from near Mills Gap (D-2) on the south, to near Utah State Highway 132 on the north (fig. 16), where it abuts an erosional remnant of the Charleston-Nebo overthrust. The fold is composed of Cretaceous and Tertiary strata (North Horn), and Tertiary strata (Flagstaff, Colton, and Green River Formations) that are unconformably overlain by volcaniclastic beds of the Eocene and Oligocene Goldens Ranch Formation. The volcanic units of the Goldens Ranch have been warped and faulted along with the underlying sedimentary units. In general, both flanks dip away from the crest of the fold at about $20^{\circ}$ to $30^{\circ}$.

In several places, elongate veins of banded calcite intrude the volcanic units. One of these veins, about $850 \mathrm{~m}(2,800 \mathrm{ft})$ long and $8 \mathrm{~m}(25 \mathrm{ft})$ wide, trends about N. $75^{\circ}$ E. through $\mathrm{C}$ sec. 16, T. 13 S., R. 1 W. Other small calcite seams and veins, most of unknown length but ranging from 0.5 to $2.0 \mathrm{~m}$ (2 to 6 $\mathrm{ft}$ ) in width, intrude volcaniclastic sediments that are exposed in small knolls in the $\mathrm{E} 1 / 2$ sec. 26 , T. $13 \mathrm{~S}$., R. $2 \mathrm{~W}$.

\section{DISCUSSION}

Although the Arapien Shale is nowhere exposed in the West Hills, recent drilling by Placid Oil Company on the crest of the fold (Howard Well No. 1-A WXC, $\mathrm{NW} 1 / 4 \mathrm{NW} 1 / 4$ sec. 5, T. 14 S., R. 1 W.) (fig. 9) indicates that the fold has a core of Arapien Shale that contains many beds of both salt and anhydrite scattered through calcareous mudstone.

The fact that the volcanics of the Goldens Ranch are deformed along with the underlying sedimentary rocks of Cretaceous and Tertiary age suggests that the folding must have occurred at some time after the middle Oligocene, the youngest age assigned to the Goldens Ranch Formation (Witkind and Marvin, 1989). As much salt is contained in the Arapien core of the fold, it seems reasonable to surmise that the folding may stem from movement of the salt.

The calcite veins that intrude the volcanic mantle would seem to support the view that the deformation is the result of movement of the Arapien core. Presumably some of the evaporites of the buried Arapien were dissolved and then reprecipitated at some time after the volcanics were extruded, consolidated, and warped. Such dissolution and reprecipitation would seem most likely during episodes of diapiric deformation.

\section{VALLEY MOUNTAINS DIAPIRIC(?) FOLD}

The Valley Mountains (G-2) are a low, northtrending, oval mass about $45 \mathrm{~km}(28 \mathrm{mi})$ long and some $11 \mathrm{~km}$ (7 mi) wide (fig. 2), bounded on the west by Scipio (E-1) and Round Valleys $(\mathrm{F}-2)$ and on the east by Sevier Valley (G-2). Sevier River, flowing north through Sevier Valley, bends around the north end of the Valley Mountains and is then impounded behind Yuba Dam (E-2) to form the Sevier Bridge Reservoir (Yuba Lake). On the south, the Valley Mountains end in a small saddle formed near a southeastward bulge of the Pavant Range (H-1). Highway U.S. 50 follows the west flank of the Valley Mountains southward from Scipio to Salina (G-3). The Valley Mountains may be the site of a diapiric fold (fig. 16, 6).

\section{GEOLOGIC SETTING}

The Valley Mountains, composed chiefly of Cretaceous and Tertiary units, are an eastward-tilted fault block bounded on the west by a high-angle normal fault that trends north and dips steeply to the west. The crustal block west of the fault (greater Scipio Valley) is downthrown. The strata that form the crest of the mountains are nearly horizontal, and these are broken by many northward-trending high-angle normal faults. Comparable fault patterns are found in the Wasatch Plateau (Gilliland, 1951, p. 61). Locally, several of these faults in the Valley Mountains are paired to form grabens; one of the larger grabens so formed is an unusually straight north-trending depression expressed topographically for part of its length as Japanese Valley. Japanese Valley is about $13 \mathrm{~km}(8 \mathrm{mi})$ long and $2 \mathrm{~km}(11 / 4 \mathrm{mi})$ wide. I believe, however, that the graben extends beyond the ends of Japanese Valley, possibly reaching from South Valley (G-2) northward almost to Red Canyon (E-2), a distance of about $19 \mathrm{~km}(12 \mathrm{mi})$.

As the nearly horizontal strata that form the crest of the Valley Mountains are traced eastward they gradually flex downward to form the eastward-facing Valley Mountains monocline. As in the Wasatch monocline, far to the east, beds of the Flagstaff Limestone form much of the monoclinal slope. Younger beds, chiefly Colton, Green River, and Crazy Hollow strata, have been almost completely removed from this slope, but are preserved along and near the slope's base where they appear as small eastwarddipping cuestas. Eastward-flowing consequent (but intermittent) streams have cut deep valleys that reach far back toward the crest of the mountains.

Along the northeast and east edges of the Valley Mountains, the monocline has been breached to expose a structurally complex sequence of Cretaceous and Tertiary beds. I describe these exposures elsewhere in this Professional Paper (p. 62-66), and 
attribute the structural complexity to recurrent movement of the Sevier Bridge Reservoir diapir, and the monoclinal downwarp to dissolution of salt from that diapir.

\section{DISCUSSION}

Although mudstones of the Arapien Shale are nowhere exposed in the Valley Mountains, they have been found in the Anschutz Corporation's Monroe Fee No. 1 well (SE $1 / 4 \mathrm{SE} 1 / 4$ sec. 14, T. 20 S., R. 2 W.), and Placid Oil Corporation's WXC-USA 1-2 well $\left(\mathrm{NW}_{1 / 4} \mathrm{SW}_{1 / 4}\right.$ sec. 24, T. 19 S., R. 2 W.) (fig. 9). The Placid well is along the west flank of the mountains, and the Monroe well is in Round Valley. Although both wells penetrated the Arapien Shale, neither well cut beds of salt.

Several factors hint that the mountains are a diapiric fold somewhat similar to other diapiric folds in the area. Thus, the elongate shape of the mountains, the linear, collapsed graben (Japanese Valley) that follows the mountain crest, and the presence of Arapien mudstones in the core all favor the concept that the Valley Mountains are, or once were, underlain by a salt diapir. The graben, in particular, suggests subsidence as a result of withdrawal of salt from a causative diapir. The many north-trending faults, so much like those that break the crest of the Wasatch Plateau, also favor dissolution of salt as an explanation for their origin.

Although the two test wells failed to penetrate salt, this in itself does not necessarily mean that salt does not, or did not, underlie the Valley Mountains. Both wells, along the west flank of the fold, are considerably west of the crest of the fold, and thus could have missed the causative salt core. Previously, I have suggested (p. 12 and fig. 5) that most of the salt diapirs are long, narrow ridges of salt. Trusheim (1960, fig. 4), studying the Zechstein salt of northern Germany, has referred to comparable diapirs as "salt walls." Wells drilled along the flanks of a diapiric fold could easily miss such thin salt ridges.

\section{GRAVITY DATA}

Gravity data are available for parts of the SanpeteSevier Valley area as a result of a Bouguer gravity survey completed between 1968 and 1974 by Brown (1975, fig. 5). Brown's data were subsequently reevaluated by Brown and Cook (1982), but this new appraisal included no new data.

The gravity data reveal the general distribution pattern of the diapiric folds (fig. 52). The trends of most folds closely coincide with the gravity lows, but the trends of a few folds seemingly diverge somewhat from the determined gravity lows. Such divergence may stem from the low density contrast between the Arapien Shale and the valley fill; the contrast seemingly is just too small to be easily recognized. Brown and Cook (1982, p. 123) commented: "The expected density contrast between it [the alluvium] and the Arapien Formation is too small to be detailed in this study. Hence, alluvium will be included with the Arapien in quantitative interpretations."

The gravity map shows three elongate, faintly sinuous lows more or less coincident with the Sevier (G-3), Sanpete (E-4), and Juab valleys (C-2). Farthest south is a narrow, deep trough that trends about $\mathrm{N} .30^{\circ} \mathrm{E}$., and that coincides with that part of Sevier Valley between Richfield (I-1) and Gunnison (F-3). Near Gunnison, the trough bifurcates to form two narrow lows-an eastern one that trends about N. $20^{\circ} \mathrm{E}$. and that follows Sanpete Valley, and a western one that trends about $\mathrm{N} .20^{\circ} \mathrm{W}$. and that persists beneath Sevier Valley to underlie the Sevier Bridge Reservoir (E-2) sector. The third low, which follows Juab Valley, trends about N. $20^{\circ}$ E.; the low's south end joins the northwest-trending low beneath the Sevier Bridge Reservoir.

All three gravity lows are remarkably alikenarrow, deep, and faintly sinuous, almost straight. Locally, as in the Sevier (Salina (G-3)-Redmond (G-3) area) and Sanpete Valleys, intense gravity lows closely coincide with exposures of the Arapien Shale, strongly suggesting that at least in those areas the lows directly reflect the salt-rich diapiric cores. Elsewhere, however, the belts of Arapien mudstone, which I interpret to be the cores of the diapiric folds, are disturbingly distant from the gravity lows. For example, near Richfield (I-1) the gravity low follows the center of Sevier Valley, but the Arapien Shale exposures are some $10 \mathrm{~km}(6 \mathrm{mi})$ to the east, where

FIGURE 52 (facing page).-Bouguer gravity anomaly map of part of central Utah on which are plotted the estimated traces of several major diapiric fold crests, which generally follow the trend of three major gravity lows. The Redmond diapiric fold follows the northern part of the low underlying Sevier Valley, between Richfield and Gunnison. The Sanpete-Sevier Valley diapiric fold follows the eastern lobe of the low extending northeast from Gunnison. The Sevier Bridge Reservoir diapiric fold follows part of the western low extending northwest beneath Sevier Bridge Reservoir. From data in Witkind and Marvin (1989), another diapiric fold as yet unrecognized may coincide with the branch of the low beneath Juab Valley. Fold crests dashed where inferred, queried where speculative. Gravity data from Brown, 1975. Contour interval $10 \mathrm{mGal}$; dashed where inferred; hachured to indicate area of closed low. 


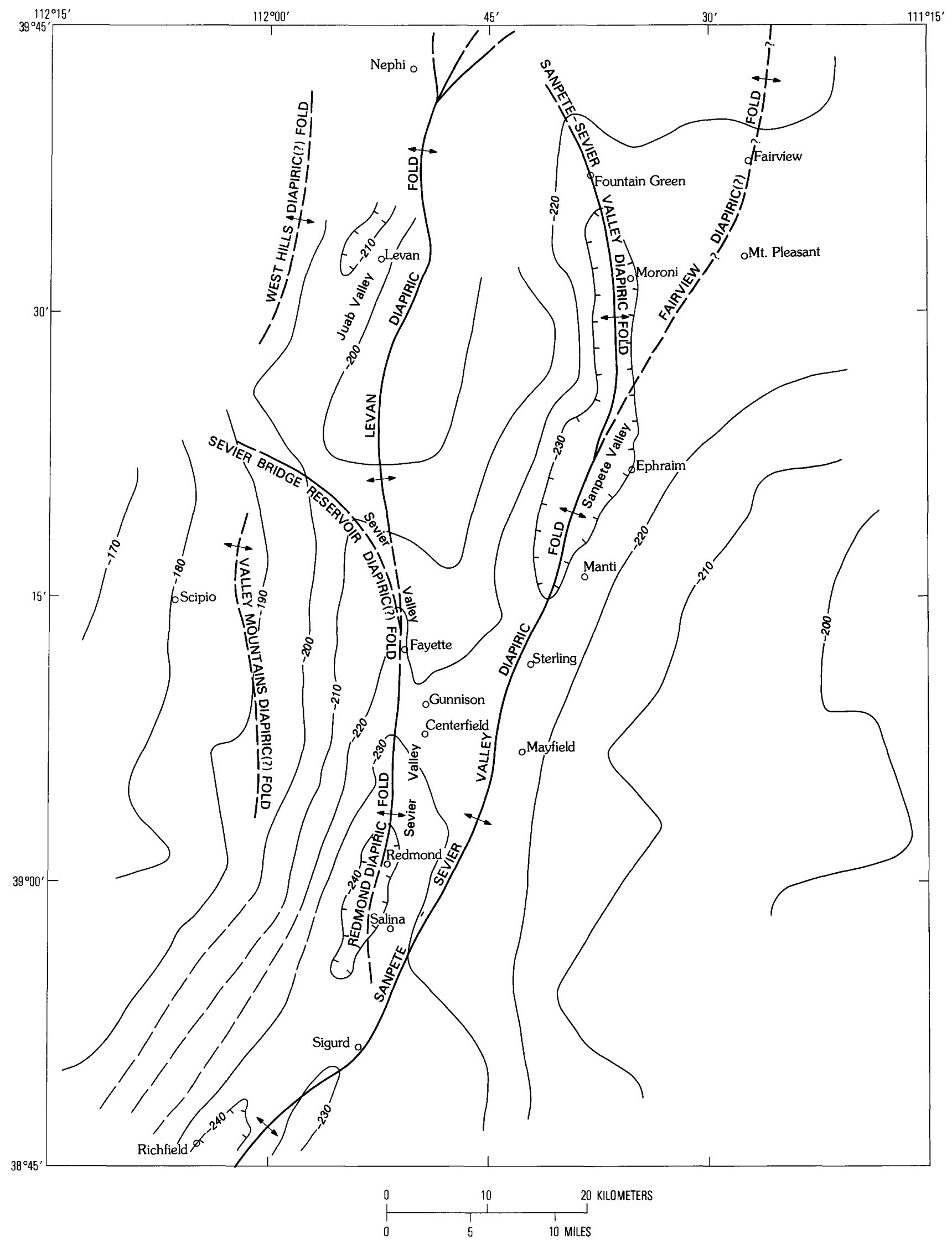


they form part of the eastern reaches of Sevier Valley. Brown and Cook (1982, p. 130) recognized this inconsistency and attributed it to an anticline formed in pre-Arapien strata and concealed beneath the Arapien. Seemingly, the Arapien over the buried anticline is relatively thin; away from the anticline the Arapien thickens and forms definitive gravity troughs.

A similar lack of agreement between a gravity low and the Arapien exposures is apparent in the Levan (C-3) area to the north. The gravity low follows the center of Juab Valley; the north-trending Arapien Shale outcrops, which mark the core of the Levan diapiric fold, are some $7.2 \mathrm{~km}(4.5 \mathrm{mi})$ to the east, where they form part of the west flank of the Gunnison Plateau. Possibly, another diapiric mass underlies Juab Valley (Witkind and Marvin, 1989).

Furthermore, two major postulated diapiric folds, the Fairview and the Valley Mountains folds, seemingly are not shown at all by the gravity data. This lack, however, may be due to the sparsity of gravity data in those localities.

\section{DIAPIRIC DEFORMATION OF THE EAST FLANK OF THE CHARLESTON-NEBO THRUST PLATE}

Most of the diapiric folds discussed previously are distinctive and readily recognized. A causative salt diapir has warped up the surface rocks into nearvertical attitudes, and these upwarped rocks precisely reflect the trend of the underlying diapir. By contrast, in this section I discuss how several of these diapirs, and their overlying diapiric folds, overridden by and concealed beneath the CharlestonNebo thrust plate, subsequently deformed the overriding plate and its mantle of younger rocks.

I am convinced that both the Levan and the Thistle Creek diapirs have broken and warped the thrust plate (p. 69-75 and 83-86). Here, I summarize material that originally appeared in USGS Professional Paper 1170-F (Witkind, 1987), which described a series of geologic exposures along the eastern margin of the thrust plate that seemed most reasonably explained by diapiric uplift of the thrust plate and its sedimentary and volcanic cover.

In brief, Cretaceous and Tertiary sedimentary and volcanic strata unconformably overlie the sinuous erosional escarpment (p. 83 and fig. 4) formed along the eastern margin of the thrust plate. Wherever these strata abut and overlie the escarpment they invariably dip away from it, regardless of the escarpment's trend. For example, remnants along that part of the escarpment that trends northward dip generally east or northeast; elsewhere, where the escarpment trends eastward the remnants dip south or southwest. Within short distances from the escarpment, however, the beds reverse dip and consistently dip toward the escarpment. A narrow to broad, ill-defined, sinuous syncline thus rims the escarpment. In my view, the tilted strata adjacent to the escarpment are the remnants of an upwarp formed when the east edge of the thrust plate was lifted up and arched long after the plate was emplaced, eroded, and buried beneath these younger Cretaceous and Tertiary strata. I attribute this uplift and warpage to upward movement of one or more diapiric folds concealed beneath the plate. I believe that the width of the marginal syncline at any one place is determined by the distance between the escarpment and one or another of several diapiric folds, described previously, that crop out east of the escarpment.

In my earlier report (Witkind, 1987), I described nine localities marked by these upturned Cretaceous and Tertiary beds. Eight of these nine localities are alike, in that tilted beds of mudstone and clastic rocks of the North Horn Formation unconformably overlie Paleozoic and Mesozoic beds that form the escarpment cut on the thrust plate. In the ninth locality, the tilted beds that overlie the escarpment are volcanic rocks of the Moroni Formation. Of the nine localities marked by tilted strata, three-Salt Creek (fig. 54), Taylor Fork (fig. 56), and Red Lake (fig. 57)-are characterized by strata that dip eastward. In another three localities-Black Canyon (fig. 55), Payson Canyon (fig. 58), and Thistle Creek (fig. 44)-the strata dip southeastward; and in two localities-Bennie Creek (fig. 58), and Loafer Mountain - the strata dip southwestward. In Santaquin Canyon (fig. 59), the North Horn strata dip northward. In all localities, no matter what the direction of dip, the strike of the overlying younger strata parallels the escarpment. This parallelism, coupled with these divergent directions of dip, implies some structural relationship between the thrust plate and its mantle of younger Cretaceous and Tertiary rocks.

For brevity, I omit descriptions of these localities in the present report, but do include a geologic map and cross section for eight of these localities. Photographic overviews of various of these localities are given in figure 53, and figure 3 shows the locations of all nine.

\section{IMPLICATIONS OF THE TILTED STRATA}

Seemingly, four alternative interpretations reasonably explain the deformation: 
1. The tilt of beds in the North Horn Formation is the result of drag along one or more high-angle normal faults that separate the North Horn from the escarpment.

2. Movement along the Wasatch fault zone has raised and tilted the Charleston-Nebo thrust plate eastward, resulting in eastward tilting of the overlying mantle of North Horn and younger rocks.

3. Uneven compaction, at time of deposition, of unconsolidated North Horn and younger sediments that were deposited across the eroded thrust plate resulted in the development of a pseudo-arch that reflected the buried plate. Erosion of the arch left tilted remnants of North Horn and younger beds.

4. One or more salt-generated structuresdiapiric folds-developed beneath the thrust plate and arched parts of the plate and its overlying mantle of younger rocks.

\section{DRAG ALONG NORMAL FAULT OR FAULTS}

I could find no evidence of normal faults separating the North Horn from the escarpment. Possibly such faults do exist, but if so they are concealed beneath debris and foliage. It seems unlikely, however, that a single unbroken fault extends along the length of the entire escarpment; such a fault would be marked by an extremely complex and sinuous trace having several right-angle bends.

\section{MOVEMENT ALONG THE WASATCH FAULT ZONE}

Clearly all sorts of attitudes are possible along a large, complex fault zone. Still, if the thrust plate was raised and tilted eastward as a result of movement along the Wasatch fault zone, all North Horn strata draped across the plate should dip eastward. In fact, some North Horn beds that are along the west side of the southern Wasatch Range (near Santaquin), but east of the Wasatch fault zone, dip westward (fig. 59). Moreover, although the North Horn along the east flank of the escarpment does dip eastward, comparable units dip northward near the head of Santaquin Canyon, and southward in the Payson Canyon and Bennie Creek areas.

\section{UNEVEN COMPACTION OF UNCONSOLIDATED NORTH HORN} FORMATION AND YOUNGER SEDIMENTS

Uneven compaction of unconsolidated sediments deposited across the exposed, sloping, and eroded escarpment would result in beds of sedimentary rocks that dip away from the buried plate. As younger sediments were deposited on these rocks and then unevenly compacted, the new units would have still lower dips. The end result would be a stack of sedimentary units with each younger unit marked by somewhat lower dips. This pattern is not apparent in the exposures discussed. The impression created is that all units in the sedimentary stack are parallel and were tilted concurrently.

\section{UPLIFT AS A RESULT OF SALT DIAPIRISM}

One or more diapiric folds, concealed beneath the thrust plate, raised and warped parts of the plate, and in so doing arched the overlying North Horn and younger strata. I believe that the Thistle Creek diapiric(?) fold deformed the northern sector of the erosional escarpment cut across the plate, even as the Footes Canyon diapiric(?) fold (the middle fold of the three formed when the Levan fold trifurcated) deformed the southern sector.

Although all four alternatives seem reasonable, it seems to me that only two-differential compaction of unconsolidated sediments, and salt diapirism-are acceptable alternatives. Inadequate exposures preclude complete acceptance of either. I believe, however, that salt diapirism is the best explanation, and point to the deformation near Thistle as an example of such warpage of younger beds by uplift of the thrust plate.

\section{DISCUSSION}

Almost all the structural complexity in the SanpeteSevier Valley area is most reasonably and simply explained as the result of the repeated growth and collapse of salt-generated diapiric folds. These recurrent episodes of salt diapirism, which began during the Mesozoic and have persisted into the Quaternary, have stamped a unique geologic pattern on this sector of central Utah. It seems unreaonable to assume that these diapiric folds are restricted only to that part of the area that lies in front of the thrust plate. The folds must be impressed on that part of the area overlain by the thrust plate; if so, the folds must have deformed the thrust plate, too. Still, some relationship must exist between the thickness of the "mother bed" of salt, the amount of overburden, and the degree of diapirism. Where the overburden is thick, as in those localities overlain by the thrust plate, possibly the diapirism is restricted and diapiric features are few in number; where the overburden is thin, the diapirism is more active and as a result its features are widespread. 

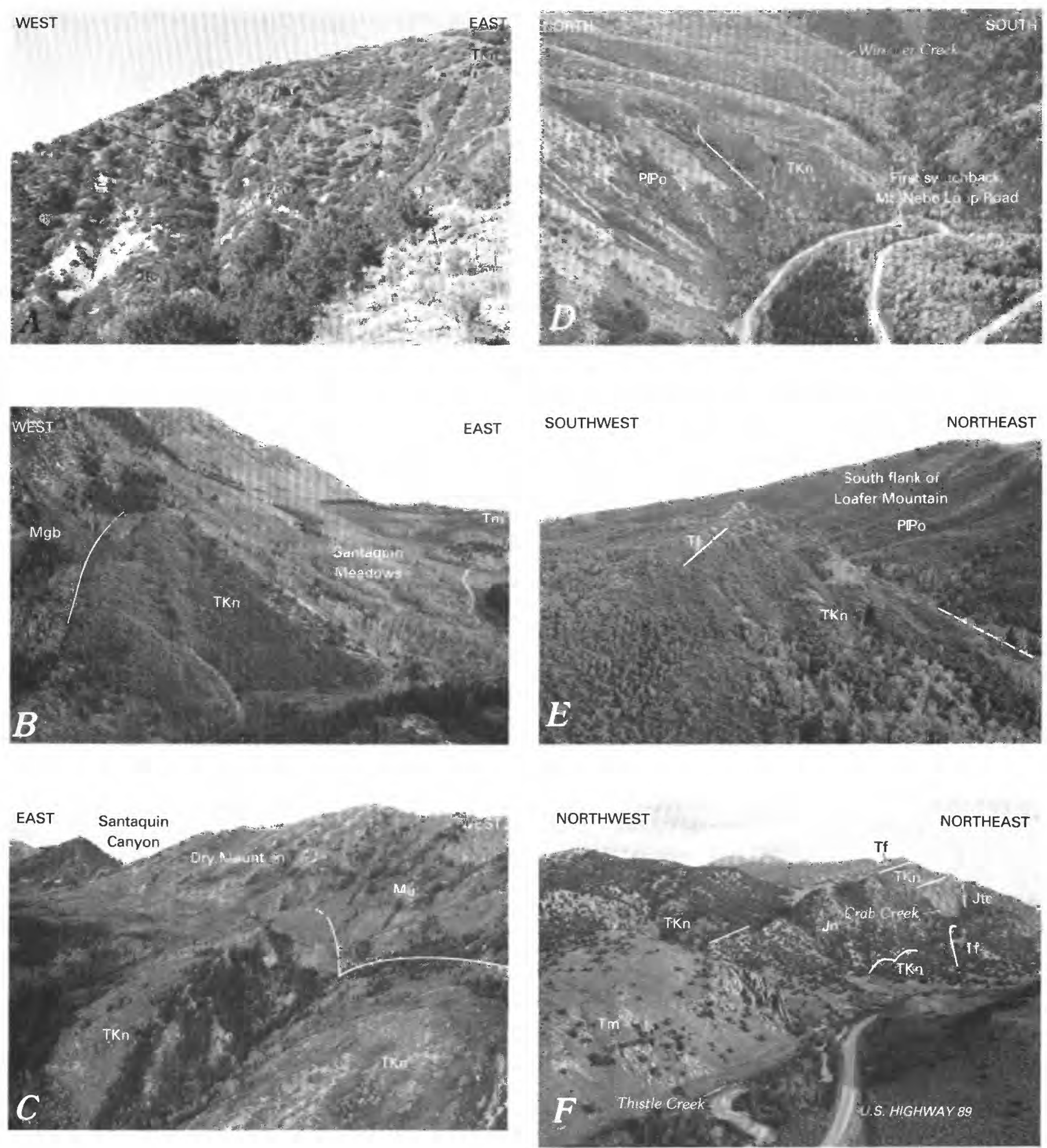
FIGURE 53 (facing page)._-Photographic overviews of localities adjacent to the erosional escarpment bordering the CharlestonNebo thrust plate. In all localities, clastic beds of the North Horn Formation unconformably overlie the escarpment formed on the Charleston-Nebo thrust plate. Dashed lines delineate angular unconformity between the North Horn and underlying units. The North Horn invariably dips away from the escarpment. A, View northward in Salt Creek Canyon showing eastward-dipping sandstone beds of the North Horn Formation (TKn) unconformably overlying overturned beds of the Navajo Sandstone (Jn) and Twin Creek Limestone (Jtc). The Navajo and Twin Creek dip northwestward (away from viewer) and are part of the escarpment. The eastward dip of the North Horn strata lessens and is almost horizontal near the right (east) edge of the photograph. Farther to the east, beyond the right edge of the photograph, the North Horn reverses dip and is inclined westward toward the escarpment. See figure 54 for geologic map of this locality. $B$, View northward along the east flank of Dry Mountain in Taylor Fork near the head of Santaquin Canyon. Clastic beds of the North Horn Formation (TKn), which strike northward and dip eastward, unconformably overlie beds of the Great Blue Limestone (Mgb), which is part of the erosional escarpment formed on the Charleston-Nebo thrust plate. Volcanic units of the Moroni Formation (Tm) unconformably overlie the North Horn Formation, and seemingly are deformed along with it. See figure 56 for geologic map of this locality. $C$, View southward along east flank of Dry Mountain, near Red Lake, showing eastward-tilted clastic beds of the North Horn Formation (TKn) unconformably overlying eastward-tilted undivided Mississippian strata $(\mathrm{Mu})$ that are part of the escarpment on the Charleston-Nebo thrust plate. See figure 57 for geologic map of this locality. $D$, View eastward at exposures near head of Payson Canyon. In this locality, the escarpment bends sharply to the northeast along a reentrant cut into the thrust plate. As a result, the clastic beds of the North Horn Formation (TKn), which unconformably overlie the escarpment, strike northeast and dip southeast. The escarpment is formed on the Oquirrh Group (PPo), which also strikes northeast and dips southeast. See figure 58 for geologic map of this locality. $E$, View looking northwestward at a small hogback, near the head of Bennie Creek, along south flank of Loafer Mountain. The hogback is formed by southward-dipping clastic beds of the North Horn Formation (TKn) that are capped by a thin lightgray bed of the Flagstaff Limestone (Tf). The North Horn rests unconformably on the Oquirrh Group (PPo), which strikes northwestward and dips northeastward, and forms part of the east-trending escarpment. See figure 58 for geologic map of this locality. $F$, View northward along west valley wall of Thistle Creek. The escarpment formed on the Charleston-Nebo thrust plate is exposed in a small gap eroded in a mantle of folded younger Cretaceous and Tertiary units. The escarpment is represented by steep eastward-dipping beds of the Navajo Sandstone $(\mathrm{Jn})$ and the Twin Creek Limestone (Jtc). The folded Cretaceous-Tertiary mantle is represented by sedimentary beds of the North Horn Formation (TKn) and the Flagstaff Limestone (Tf), and by volcanic units of the Moroni Formation (Tm). Only remnants of the sedimentary cover are preserved along the base of the west valley wall of Thistle Creek, but the cover is extensively exposed on the uplands both east and west of the creek. In general, the beds that form the cover west of the exposed escarpment dip westward; those that form the cover east of the escarpment dip eastward. See figure 44 for geologic map of this locality.
I propose that the Footes Canyon diapiric(?) fold (fig. 16, 13) and the Thistle Creek diapiric fold (fig. 16, 11) raised parts of the thrust plate after the plate was emplaced, eroded, and then covered by North Horn and younger strata. As a result, the overlying North Horn and younger beds were more or less uniformly arched.

I do not know how far to the north the Footes Canyon fold continues beneath the plate. Possibly the concealed fold extends as far north as Santaquin Canyon, as suggested by isolated outcrops of tilted North Horn beds exposed on both sides of the thrust plate. Along the east flank of the southern Wasatch Range, in the Taylor Fork and Red Lake areas, the North Horn and younger beds dip eastward (fig. 59). Directly to the west, on the opposite side of the mountains, patches of the North Horn Formation overlain by small eroded remnants of the Flagstaff Limestone dip westward. These opposing dips developed in North Horn and younger strata exposed on opposite sides of the mountains suggest that an anticlinal fold was formed in these younger beds above an arched thrust plate, much as in the Thistle area. And, as in the Thistle area, the deformation of the rocks within the thrust plate obscures the simple, later upwarping.

The attitudes assumed by the bowed-up North Horn and younger beds were determined by the configuration of that part of the erosional escarpment on which they rested. This would explain the general eastward tilt of those North Horn and younger beds that rest on that part of the escarpment that trends north, the northward dip of North Horn strata in Santaquin Canyon where these beds overlie the north flank of an eastward-directed protuberance of the escarpment, and the southward and southwestward dips of similar strata exposed along the south flank of Loafer Mountain, where North Horn and younger beds overlie the sinuous south flank of the east-trending escarpment.

\section{DEPOSITIONAL THINNING}

Sequences of sedimentary units thin and locally pinch out near the crests of the diapiric folds. Some units wedge out by onlap against the flanks of the fold; other units thin but continue across the crests of the folds. Both the pinchouts and the thinning presumably result from impeded deposition. This depositional thinning appears to influence sequences of units rather than just one discrete unit in a 


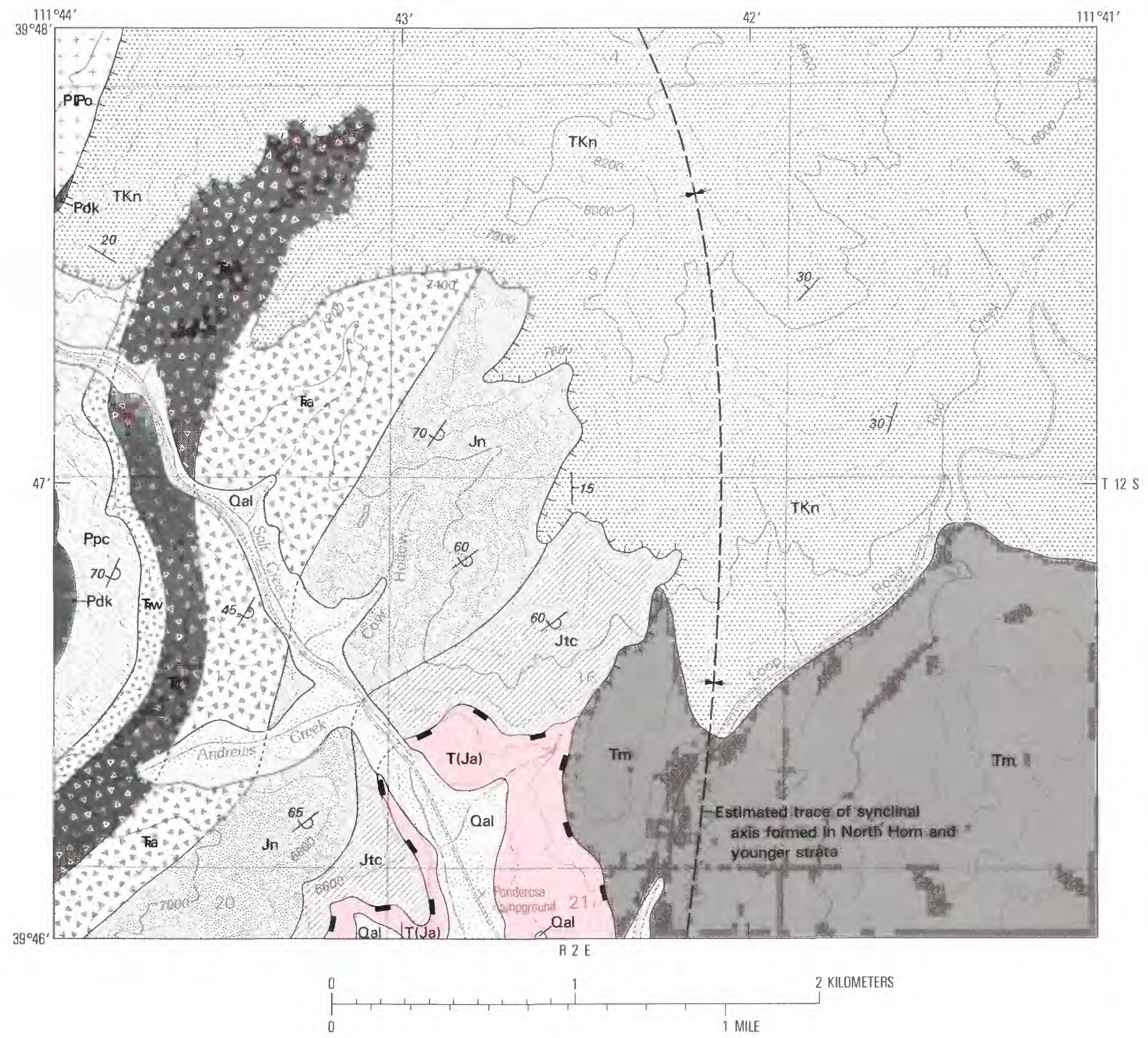

Figure 54 (above and facing page).-Geology of Salt Creek area. Geology slightly modified from Witkind (1987, fig. 6). Base modified from U.S. Geological Survey 1:24,000 Nebo Basin (1979). Contour interval $200 \mathrm{ft}$. Overturned Paleozoic and Mesozoic strata that strike northeast and dip northwest mark the erosional escarpment formed on the Charleston-Nebo thrust plate. These beds are mantled by beds of the North Horn (TKn) and Moroni (Tm) Formations. The North Horn strata that overlie the escarpment dip eastward; a short distance away from the escarpment the strata reverse dip and are inclined toward the escarpment. See figure $53 \mathrm{~A}$ for photographic overview of this locality. sequence. This thinning affects beds that range in age, at the least, from Middle(?) Jurassic to early Tertiary.

This widespread pattern of depositional thinning involving sequences of sedimentary units near the crests of folds provides some of the most compelling evidence that diapirism has played a significant role in the structural evolution of this part of central
Utah. If but one unit thinned as a result of onlap onto a static topographic high, younger sediments would, in time, bury the ancestral high. This is not the case in central Utah. All stratigraphic units near the crests of the folds thin, implying that a dynamic ancestral high-the diapiric fold - continued to move upward slowly even as the younger sediments were being deposited. 


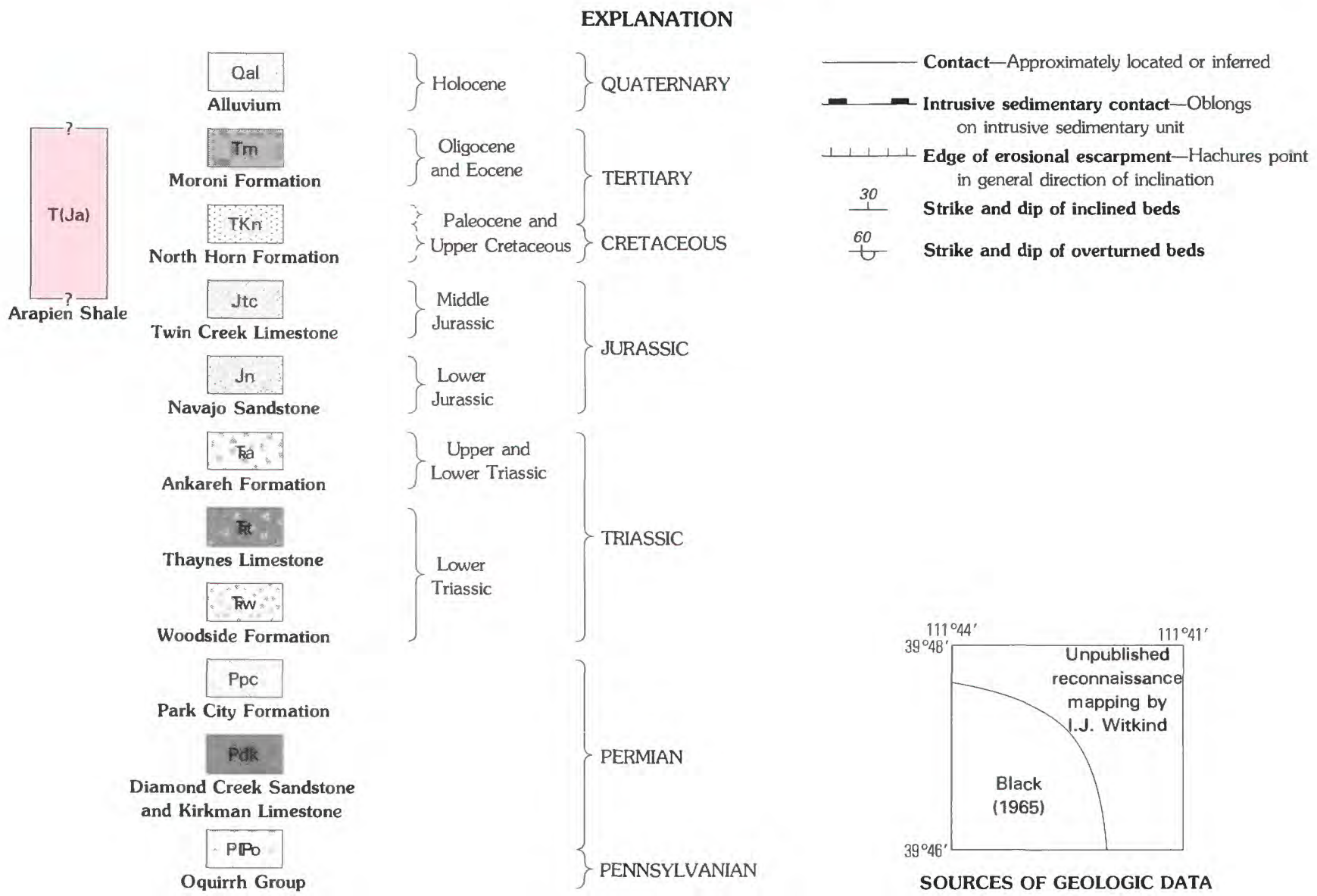

Good examples of this depositional thinning are widespread; several are discussed following.

\section{SANPETE-SEVIER VALLEY DIAPIRIC FOLD}

In Wales Gap (D-4) (along the east flank of the Gunnison Plateau), near the crest of the SanpeteSevier Valley diapiric fold, the Indianola Group, which is thousands of meters thick elsewhere, is but $35 \mathrm{~m}$ (115 ft) thick. Similarly, the Cedar Mountain Formation at Wales Gap is only $18 \mathrm{~m}(60 \mathrm{ft})$ thick but is almost $430 \mathrm{~m}(1,400 \mathrm{ft})$ thick away from the diapiric core of the fold.

The Sixmile Canyon ( $\mathrm{F}-4)$ area (along the west margin of the Wasatch Plateau) is just east of the crest of the Sanpete-Sevier Valley diapiric fold. The Price River, North Horn, and Flagstaff Formations are all extremely thin near the mouth of Sixmile Canyon but thicken markedly eastward away from the diapiric crest. The Flagstaff Limestone, for exam-

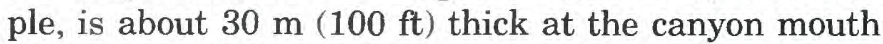
but at least $365 \mathrm{~m}(1,200 \mathrm{ft})$ thick some $10 \mathrm{~km}(6 \mathrm{mi})$ to the east along the top of the Wasatch Plateau.
In various localities in Sanpete Valley, such as near ancestral Willow Creek (G-3), and in place after place along the west flank of the Gunnison Plateau, uppermost Green River strata unconformably overlie the Arapien Shale (Witkind, Weiss, and Brown, 1987). These localities are along the flanks of the diapiric folds, and I interpret the stratigraphic relations to mean that units below the Green River, such as the North Horn, Flagstaff, and Colton, have pinched out against the flanks of the rising fold. The fact that uppermost Green River strata, unbroken but anomalously thin, mantle the fold's crest, implies that lower Green River and older sediments pinched out against the fold's flanks. Seemingly, during late Green River time deposition was rapid enough to surmount the rising mass of Arapien.

\section{SEVIER BRIDGE RESERVOIR DIAPIRIC FOLD}

Along the northeast flank of the Valley Mountains (G-2), the North Horn, Flagstaff, Colton, and Green River Formations are anomalously thin where they form part of the southwest flank of the Sevier Bridge 

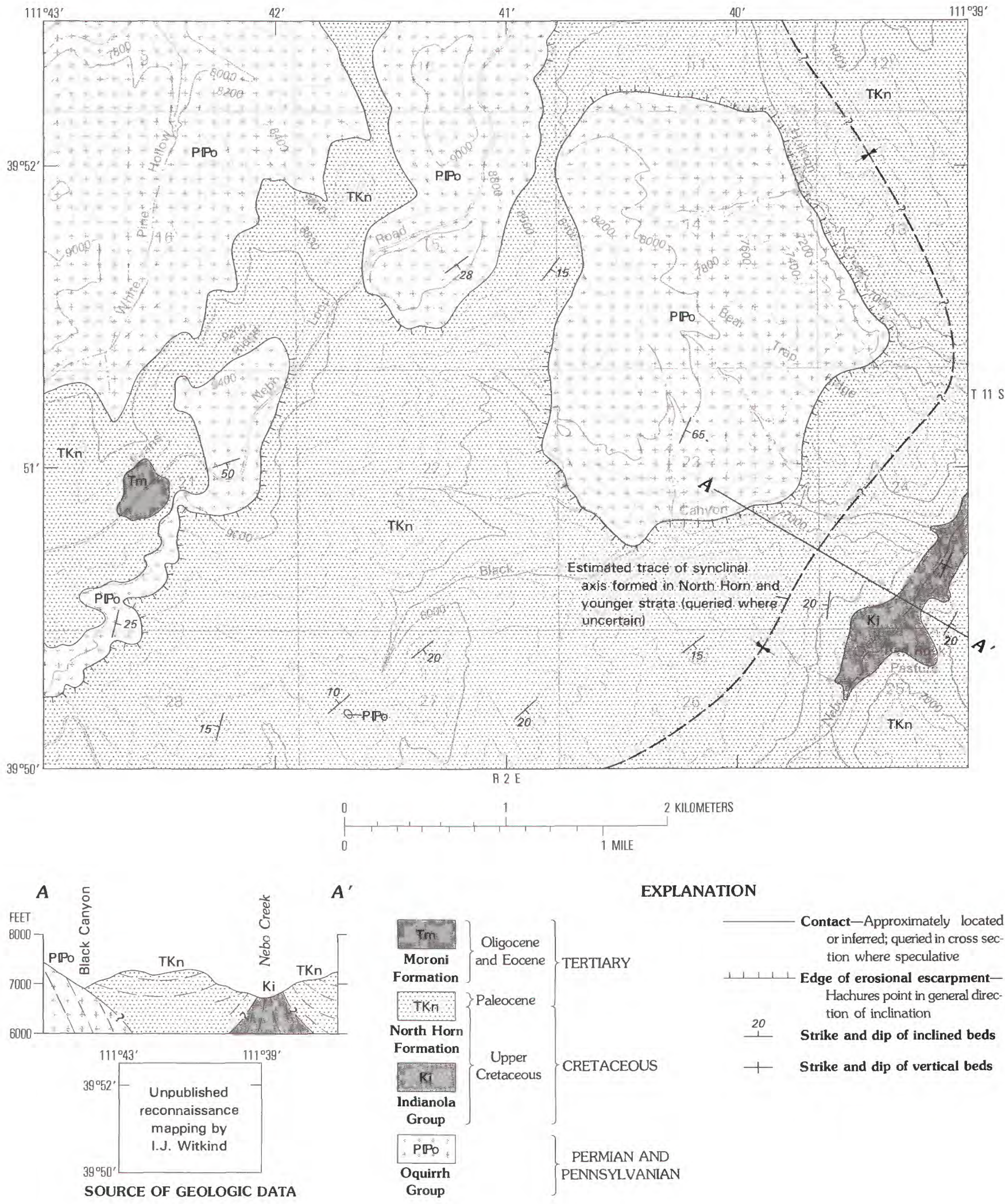
Reservoir diapiric fold. So, for example, the North Horn is about $38 \mathrm{~m}$ (125 ft) thick, the Flagstaff about $11 \mathrm{~m}(37 \mathrm{ft})$, the Colton about $61 \mathrm{~m}(200 \mathrm{ft})$, and the Green River about $53 \mathrm{~m}$ ( $175 \mathrm{ft})$ thick. As these units are traced perpendicularly away from the crest of the fold, they thicken rapidly; within about a kilometer $(0.6 \mathrm{mi})$ the North Horn has increased in thickness to about $91 \mathrm{~m}(300 \mathrm{ft})$, the Flagstaff to about $49 \mathrm{~m}(160$ $\mathrm{ft})$, the Colton to $82 \mathrm{~m}(270 \mathrm{ft})$, and the Green River to about $95 \mathrm{~m}(310 \mathrm{ft})$.

The same pattern of depositional thinning is apparent in Red Canyon (E-2) (in the Valley Mountains) along the west flank of the Sevier Bridge Reservoir fold. The North Horn Formation, for example, is about $15 \mathrm{~m}$ (50 ft) thick near the canyon mouth, but more than $180 \mathrm{~m}(600 \mathrm{ft})$ thick $1.5 \mathrm{~km}(1 \mathrm{mi})$ to the west near the head of Red Canyon.

Both along the northeast flank of the Valley Mountains and in Red Canyon, as far as I can determine, only the younger, upper parts of the formations are represented, implying that the older, lower parts of the formations pinched out against the flanks of the diapiric folds.

\section{POLE CREEK DIAPIRIC FOLD}

Units that are part of the southeast flank of the Pole Creek diapiric fold crop out in the Middle Fork Pole Creek (B-4) (fig. 39). These units, which include the Middle Jurassic Twist Gulch Formation and the Lower Cretaceous Cedar Mountain Formation, are vertical and anomalously thin. The Twist Gulch is only about $60 \mathrm{~m}(200 \mathrm{ft})$ thick; elsewhere in the Sanpete-Sevier Valley area, the Twist Gulch is about $915 \mathrm{~m}$ (3,000 ft) thick. The Cedar Mountain, east of and conformably overlying the steeply dipping Twist

FIGURE 55 (facing page)_-Geology of an area along and near Black Canyon. Geology slightly modified from Witkind (1987, fig. 7). Base modified from U.S. Geological Survey 1:24,000 Nebo Basin (1979). Contour interval $200 \mathrm{ft}$. Clastic beds of the North Horn Formation (TKn), which are juxtaposed against the escarpment formed on the thrust plate, strike northeast and dip southeast, and unconformably overlie units of the Oquirrh Group (PPo) of similar strike and dip. These North Horn units reverse dip west of Nebo Creek, reflecting the west flank of a diapiric fold (possibly a segment of the Thistle Creek fold (fig. 16, 11), part of which is exposed in sections 24 and 25. Cross section is not deep enough to include the Charleston-Nebo thrust fault, which is the sole of the thrust plate.
Gulch strata, is only about $245 \mathrm{~m}$ (800 ft) thick; elsewhere, the Cedar Mountain is as much as $430 \mathrm{~m}$ $(1,400 \mathrm{ft})$ thick.

\section{THISTLE CREEK DIAPIRIC FOLD}

In the Thistle area, various of the Cretaceous and Tertiary units thin westward toward the crest of the Thistle Creek diapiric fold. This is perhaps best shown in Young's (1976) figure 5, which shows that all units from the North Horn to the Green River Formation thin westward toward Thistle.

\section{DISCUSSION}

Gundersen and Gilliland (1967) recognized this pattern of depositional thinning in various localities throughout the Sanpete-Sevier Valley area. As the most striking examples are near their Sanpete-Sevier Valley anticline (my Sanpete-Sevier Valley diapiric fold), their article concentrated on that part of the area. In a series of isopach maps, they demonstrated that three formations-the Price River and North Horn Formations, and the Flagstaff Limestone-thin anomalously toward the crest of the Sanpete-Sevier Valley fold; they commented (1967, p. 688): “*** each formation thins markedly towards the anticline $* * *$." Their isopach maps for the Price River (1967, fig. 2), North Horn (1967, fig. 3), and Flagstaff Limestone (1967, fig. 4) show that, on both flanks of the fold, the formations thin toward the fold crest. The Flagstaff Limestone, for example, thins westward from about $460 \mathrm{~m}(1,500 \mathrm{ft})$ along the top of the Wasatch Plateau to about $75 \mathrm{~m}(250 \mathrm{ft})$ near Sterling $(\mathrm{F}-4)$, which is along the east flank of the Sanpete-Sevier Valley diapiric fold. Gundersen and Gilliland's isopach map of the North Horn Formation demonstrates a similar pattern of thinning. The North Horn, about $460 \mathrm{~m}$ $(1,500 \mathrm{ft})$ thick along the top of the Wasatch Plateau, thins westward to only about $75 \mathrm{~m}(250 \mathrm{ft})$ near Manti (E-4), along the east flank of the SanpeteSevier Valley fold.

Farther west, in and near the Valley Mountains (G-2), Gundersen and Gilliland's isopach map (1967, fig. 3) shows the North Horn to be about $610 \mathrm{~m}$ $(2,000 \mathrm{ft})$ thick near Scipio Lake (F-2) (west of the Valley Mountains), but to thin eastward to about $230 \mathrm{~m}(750 \mathrm{ft}$ ) near Redmond (G-3), which is along 


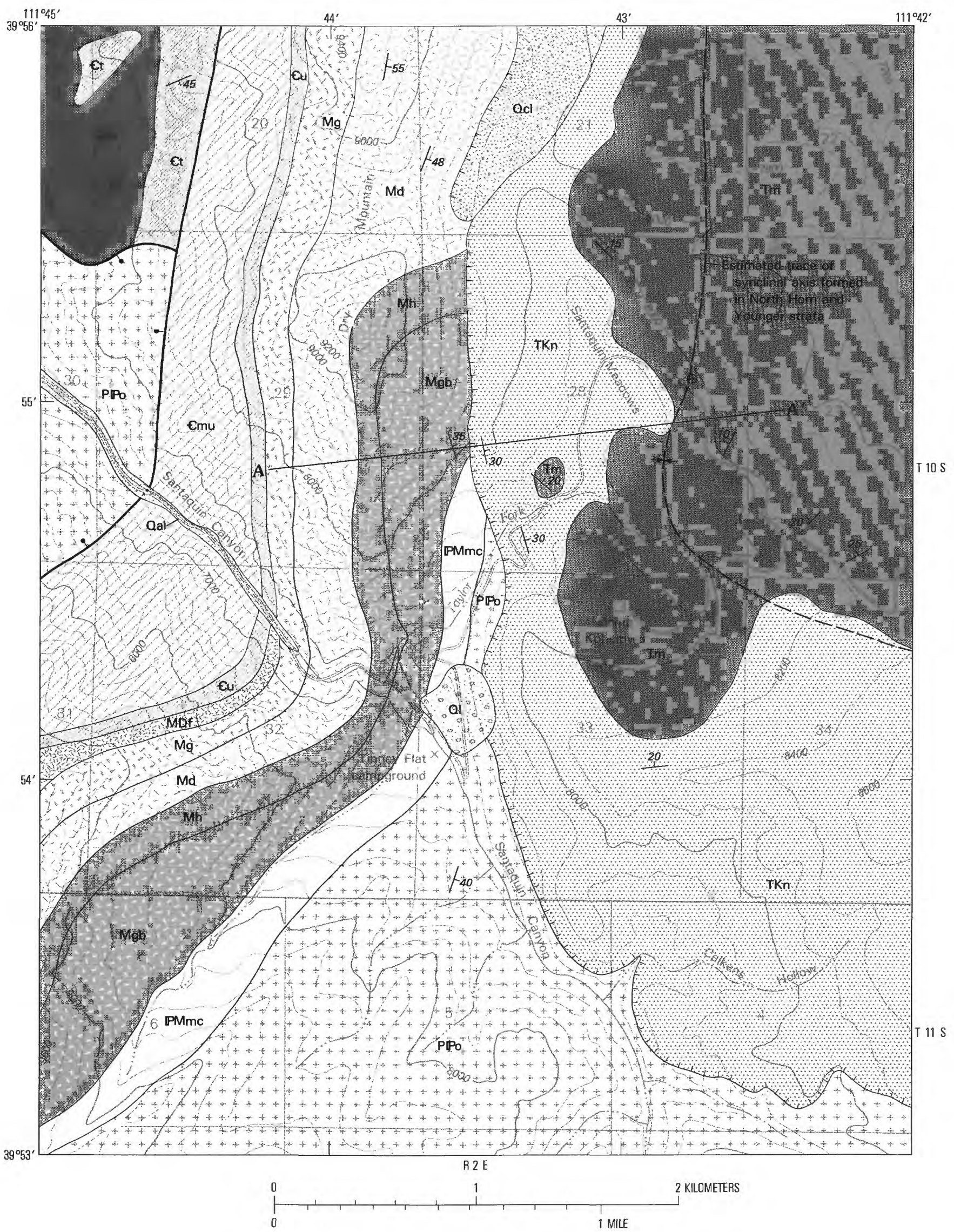


EXPLANATION

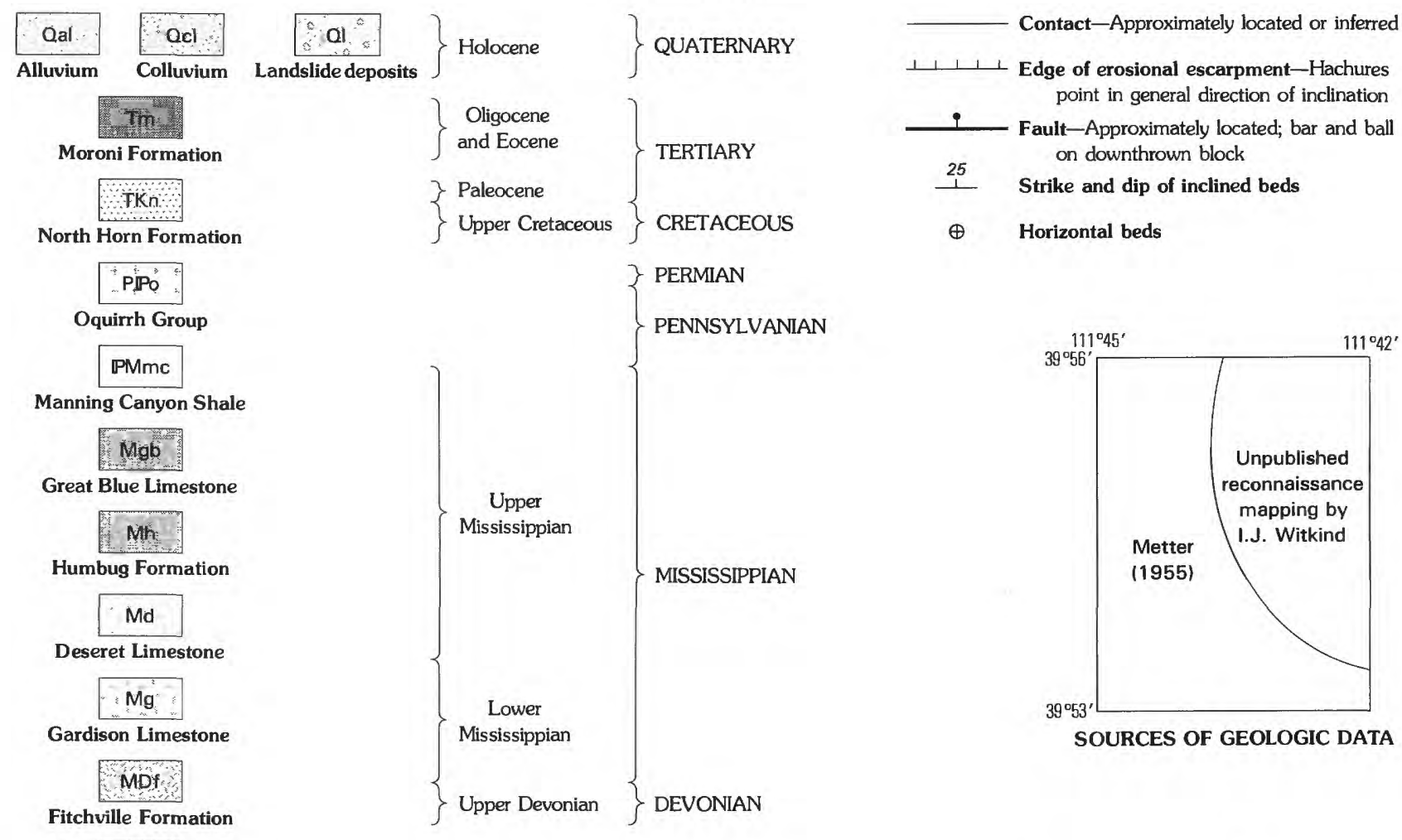

Cu

Upper Cambrian rocks, undivided

$$
\text { Emu }
$$

Middle Cambrian rocks, undivided

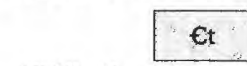

Middle Cambrian Tintic Quartzite

Late Proterozoic Big Cottonwood Formation

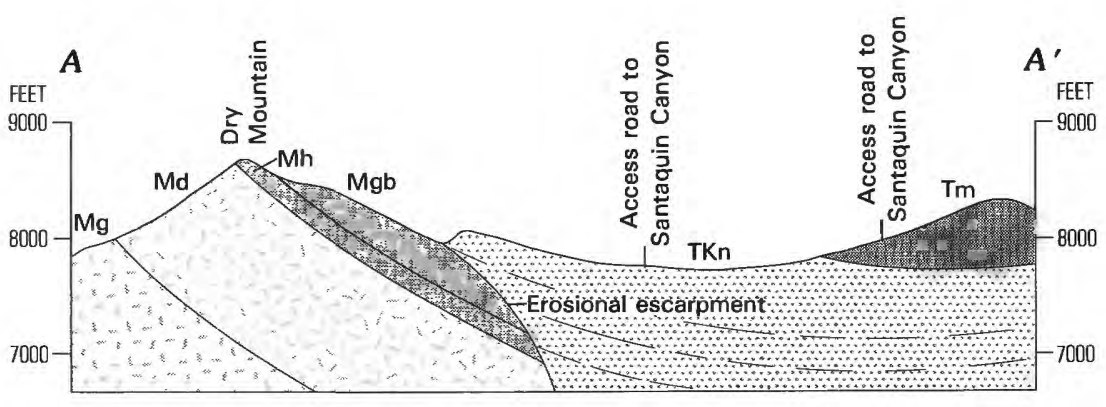

ward (see fig. $53 B$ for photographic overview of these relations). As these beds of the North Horn are traced southeastward into Santaquin Canyon, they gradually assume an eastward strike and a northward dip reflecting an eastward bulge of the escarpment. Cross section is not deep enough to include the Charleston-Nebo thrust fault, which is the sole of the thrust plate. the flank of their Redmond Hills anticline (my Redmond diapiric fold).

Willis (1986), working in the Salina Canyon area, astride the south end of the Sanpete-Sevier Valley diapiric fold, noted that North Horn and Flagstaff strata thin and locally pinch out near the crest of a north-trending "paleo-high," essentially the SanpeteSevier Valley "anticline" (Willis, 1986, p. 9). Willis indicated that Colton and Green River strata also thin toward the axis of the paleo-high.
Gundersen and Gilliland (1967, p. 686) suggested that this anomalous thinning stemmed from the Sanpete-Sevier Valley and Redmond anticlines being topographically positive elements through much of Late Cretaceous and early Tertiary time. They attributed the development of the Sanpete-Sevier Valley anticline to: "*** compression during the early Laramide orogeny."

I disagree somewhat with Gundersen and Gilliland's interpretation. I suggest instead that the 


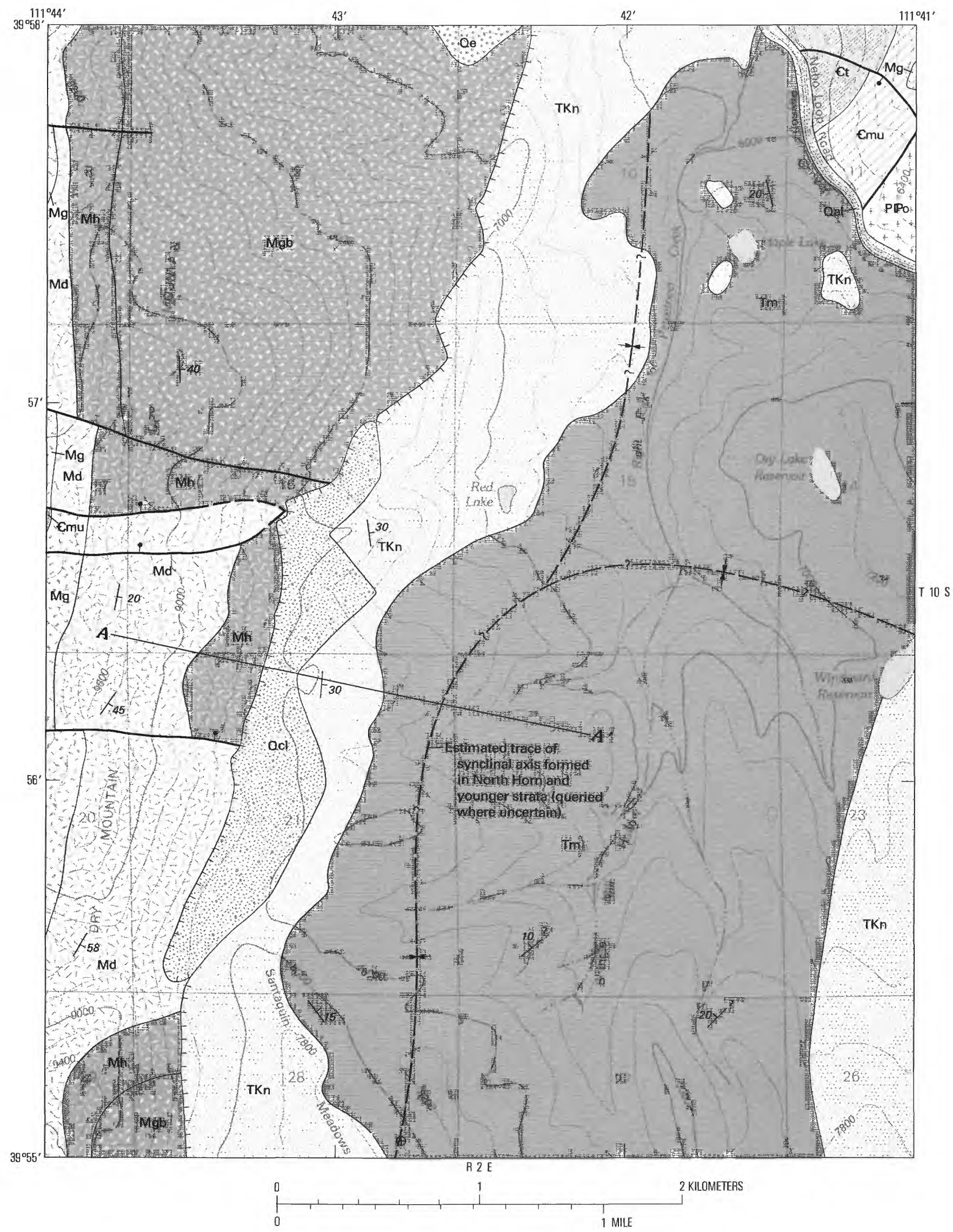


EXPLANATION
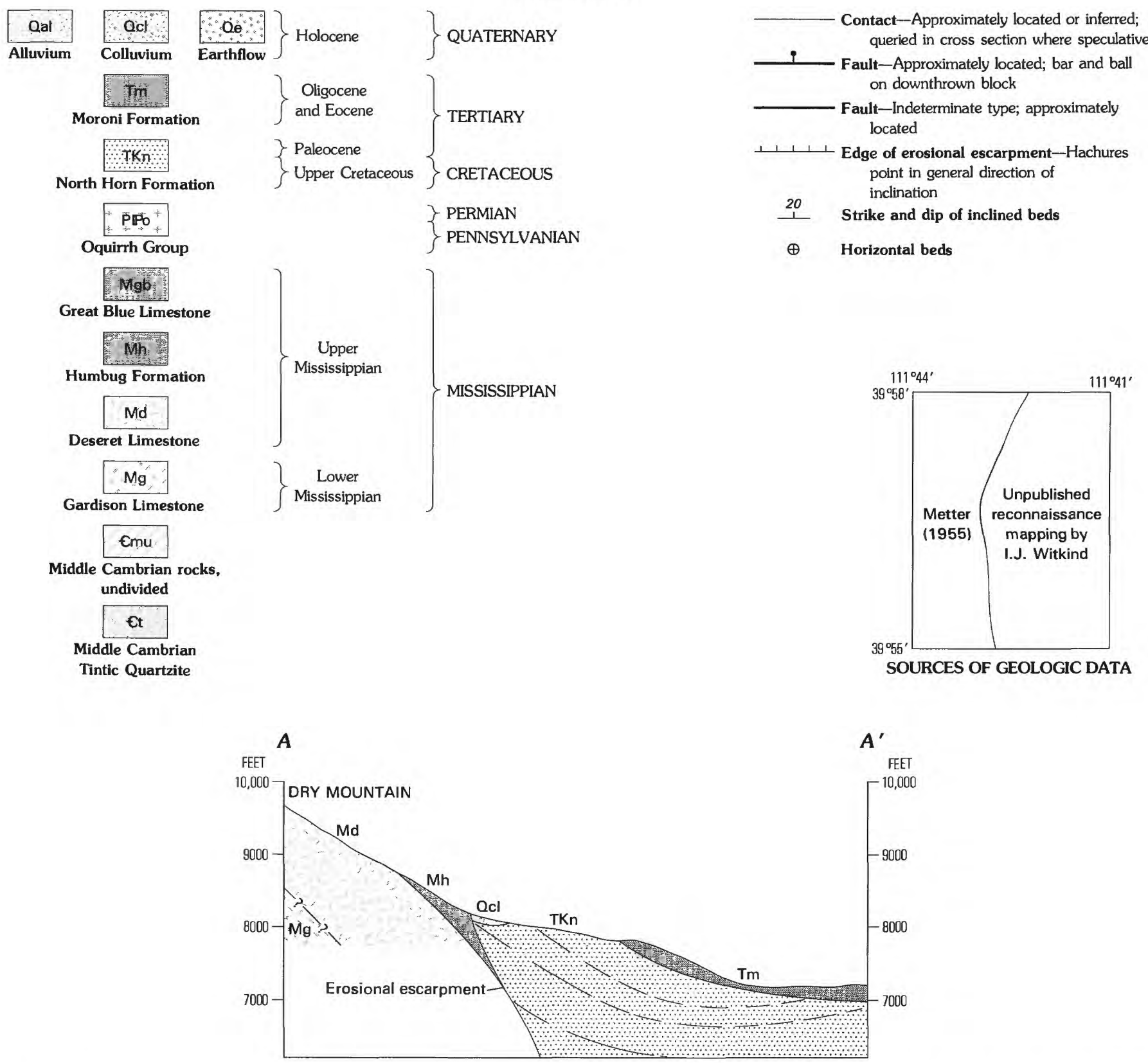

FIGURE 57 (above and facing page).-Geology of an area near Red Lake. Geology slightly modified from Witkind (1987, fig. 9). Base modified from U.S. Geological Survey 1:24,000 Payson Lakes (1979). Contour interval $200 \mathrm{ft}$. Clastic beds of the North Horn Formation (TKn) strike northward and dip eastward, and unconformably overlie a series of Mississippian strata that also strike northward and dip eastward. These Mississippian strata are part of the escarpment formed on the Charleston-Nebo thrust plate. Cross section is not deep enough to include the Charleston-Nebo thrust fault, which is the sole of the thrust plate. See figure $53 \mathrm{C}$ for general photographic overview of this locality. depositional thinning so evident in the SanpeteSevier Valley area is due to slowly rising, dynamic, salt-cored diapiric folds that probably began rising in Middle Jurassic time and continued to rise slowly throughout the Cretaceous and into the middle Tertiary. Seemingly, Gundersen and Gilliland viewed their Sanpete-Sevier Valley anticline as a dynamic feature-they demonstrated depositional thinning for at least three units. The conclusion seems inescapable-depositional thinning is reasonably explained only by invoking a dynamic, rising body. As noted above, sediments deposited against the flanks of a 


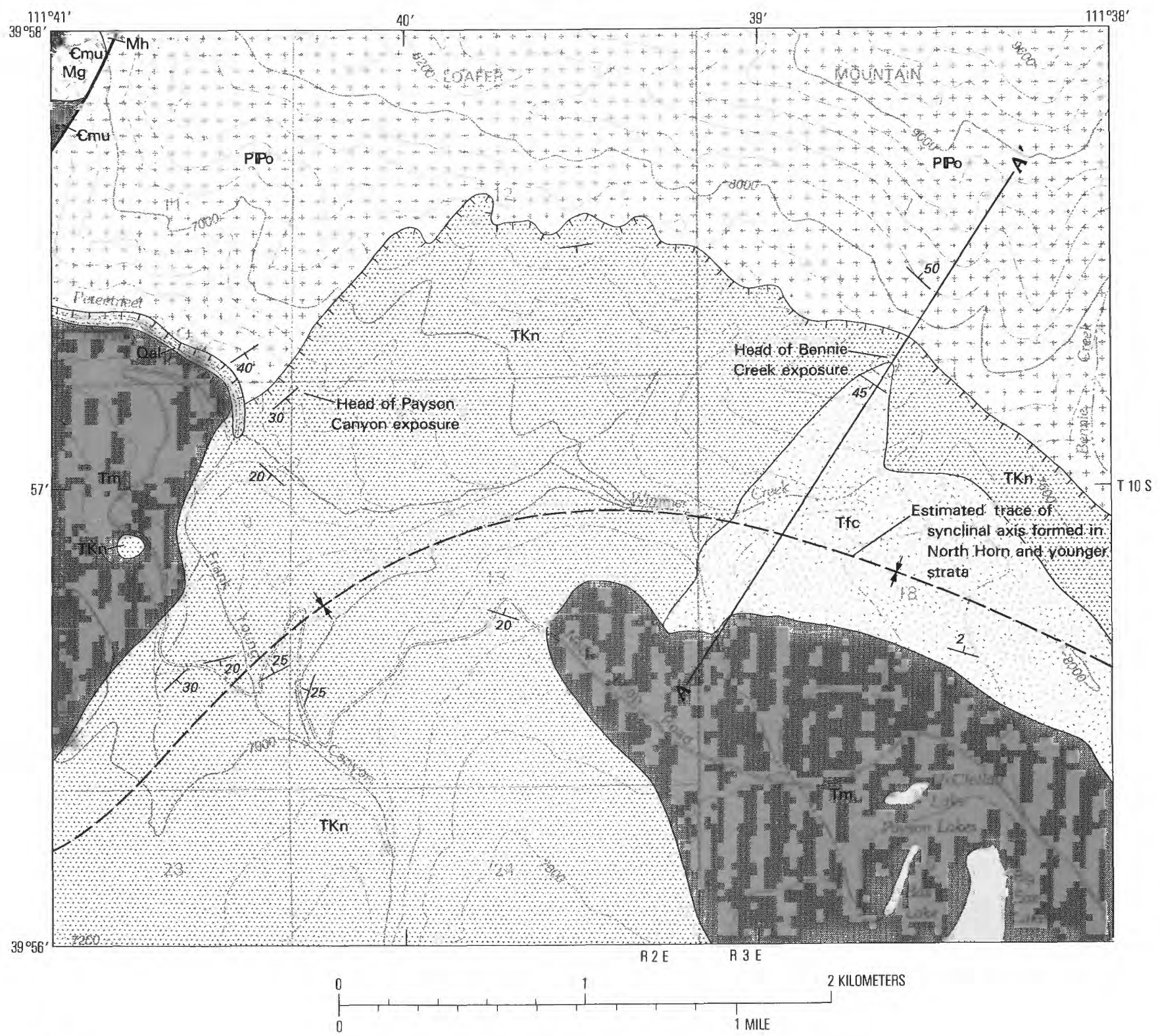

A

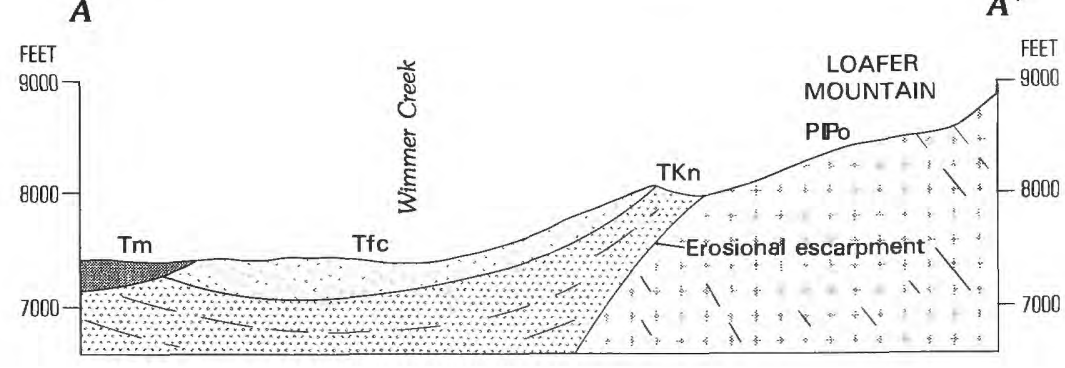

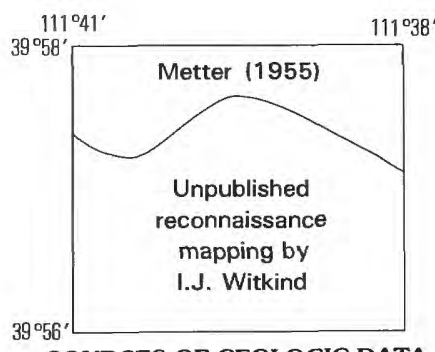

SOURCES OF GEOLOGIC DATA
FIGURE 58 (above and facing page)--Geology of an area near head of Payson Canyon and Bennie Creek. Geology slightly modified from Witkind (1987, fig. 10). Base modified from U.S. Geological Survey 1:24,000 Payson Lakes (1979). This area encompasses the north edge of the broad, eastward-facing Santaquin embayment. As a result, the escarpment formed on the
Charleston-Nebo thrust block trends eastward, and the overlying North Horn Formation dips southward. Cross section is not deep enough to include the Charleston-Nebo thrust fault, which is the sole of the thrust plate. See figure $53 D$ for a photographic overview of the exposure at the head of Payson Canyon, and figure $53 E$ for an overview of the Bennie Creek exposure. 


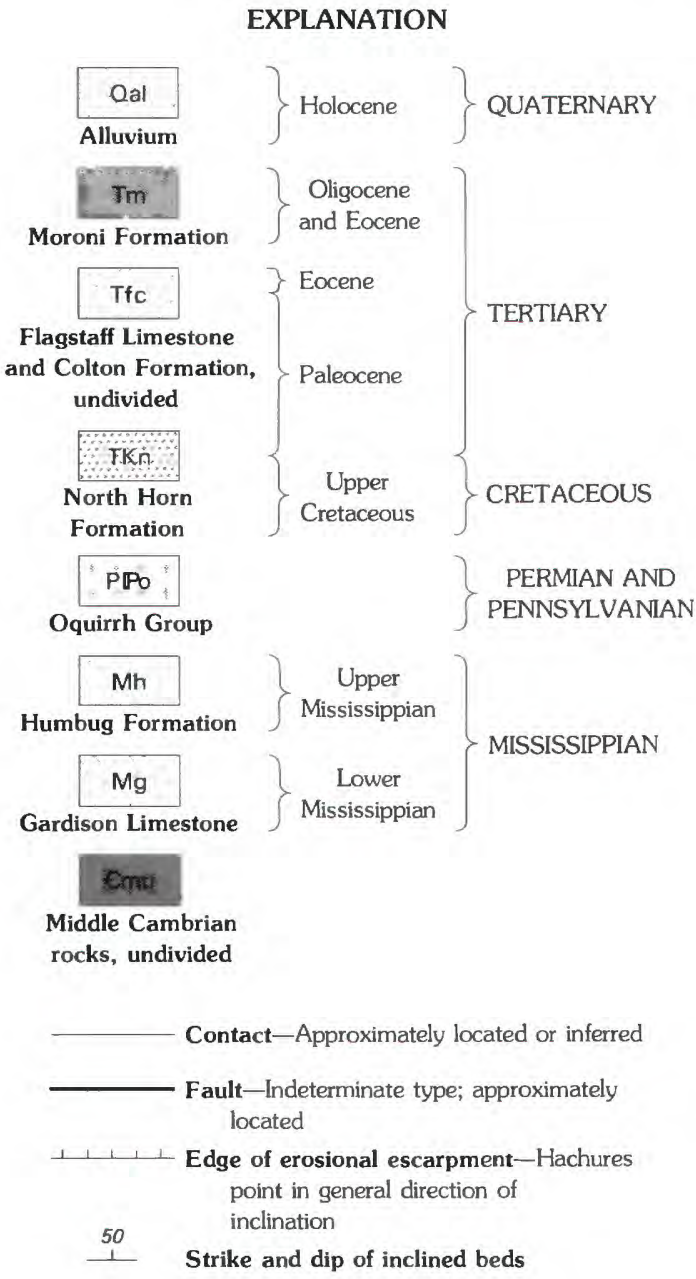

static "anticline" would eventually bury that anticline. Younger strata, unchanged in thickness, would then pass over the buried anticline and show no pattern of depositional thinning.

This anomalous thinning of the sedimentary units, although extremely localized, being confined to and near the crests of the diapiric folds, is found throughout the area. I have recognized it in the Valley Mountains (G-2) near the west end of the study area, throughout the center of the area, and to the east near Thistle (A-5). I interpret this widespread (but localized) depositional thinning to be evidence of the slow, continuous upwelling of salt in discrete diapiric folds. Seemingly, the rate of upwelling was comparable to the rate of deposition; the folds kept coming up just about as fast as the sediments kept trying to bury them. In those places where the sedimentary beds wedge out against the flanks of the fold, the fold's growth rate must have slightly exceeded the depositional rate of the sediments. Where thinned sediments overlie the crest of the fold the depositional rate must have exceeded the fold's growth rate.

Sannemann (1968, p. 357), discussing the saltstock families of northwestern Germany, suggested that salt, as it forms a salt stock (salt diapir), moves about $0.3 \mathrm{~mm}$ per year. Such movement would be difficult to detect, but would be rapid enough to form a growing barrier that would impede the comparably slow deposition of sediments. The result would be wedgeout and thinning of sedimentary units along the flanks of the growing fold.

It seems reasonable to conclude that as the folds grew they impeded sedimentary deposition throughout much of the Middle and Late Jurassic, Early and Late Cretaceous, and early Tertiary. Incomplete exposures prevent a definitive statement as to which units show this depositional thinning, but probably they include, at the very least, the sequence from the Twist Gulch Formation of Middle Jurassic age up to and including the Green River Formation of Eocene age.

Two factors seem very significant: (1) Sequences of stratigraphic units thin near the crest of a diapiric fold, and (2) invariably, where criteria are adequate to permit determination, as in the Red Rocks area ( $\mathrm{p}$. 41 ), the beds that overlie the crest of the fold are the younger and uppermost parts of the formations involved; the older and lower beds of the formations pinch out against the flanks of the fold.

\section{DIAPIRIC PROCESSES}

\section{GROWTH AND COLLAPSE OF DIAPIRIC FOLDS}

In place after place throughout central Utah, the structural complexity seems most reasonably explained by the repeated growth and collapse of diapiric folds.

\section{GROWTH OF DIAPIRIC FOLDS}

The salt within the Arapien Shale has probably been moving since shortly after it was deposited. Some of this movement has been a slow upwelling that has resulted in the development of ancestral, linear to faintly sinuous topographic highs - paleo-highs - that impeded sedimentary deposition. At times, however, the salt, in the form of a linear, narrow salt diapir, seemingly has surged upward rapidly (in a geologic sense), and forcefully. These recurrent upward surges of the causative salt diapir have forced the overlying Arapien mudstone repeatedly to bow up and fold back 

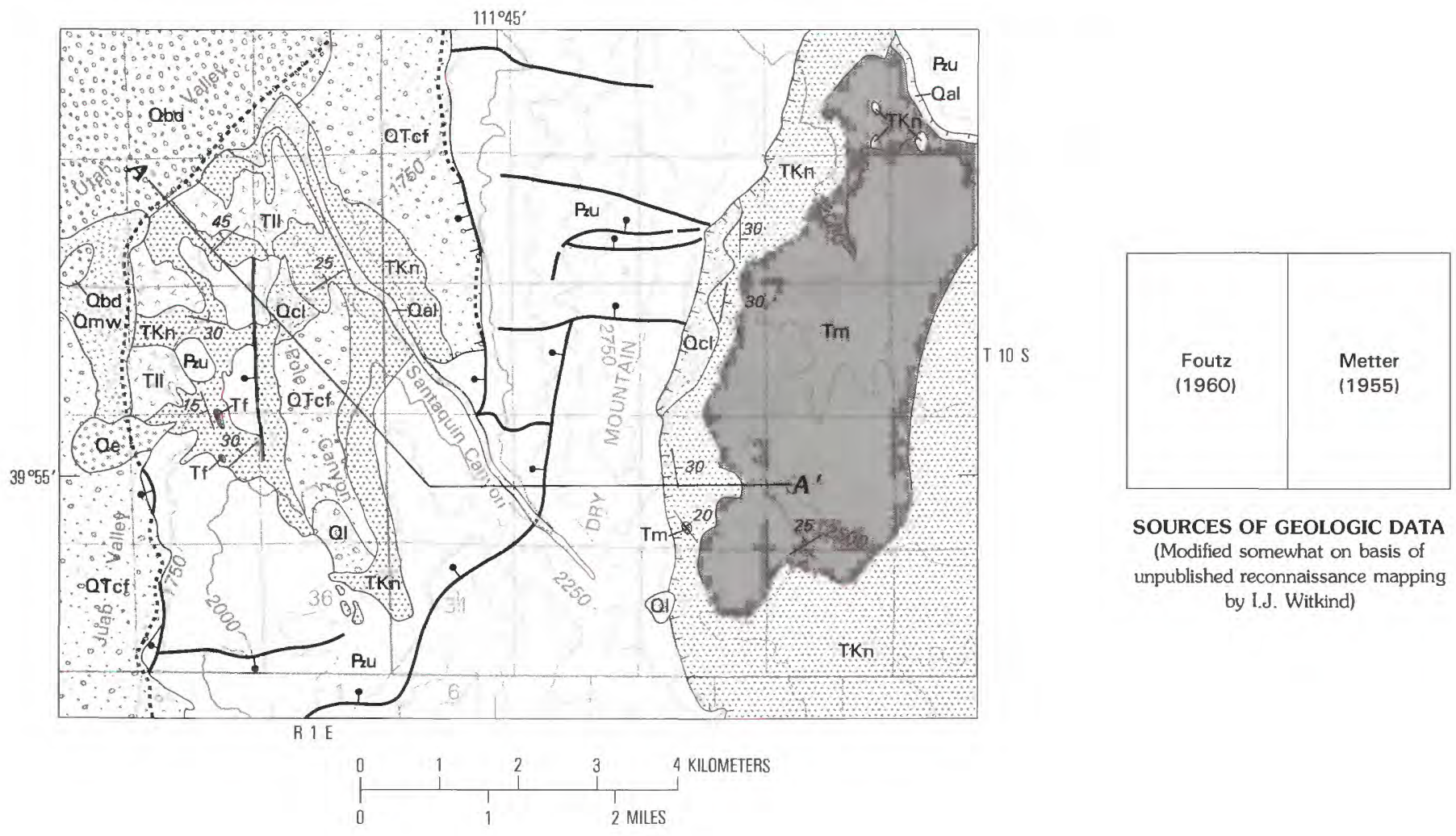

SOURCES OF GEOLOGIC DATA

(Modified somewhat on basis of unpublished reconnaissance mapping by I.J. Witkind)

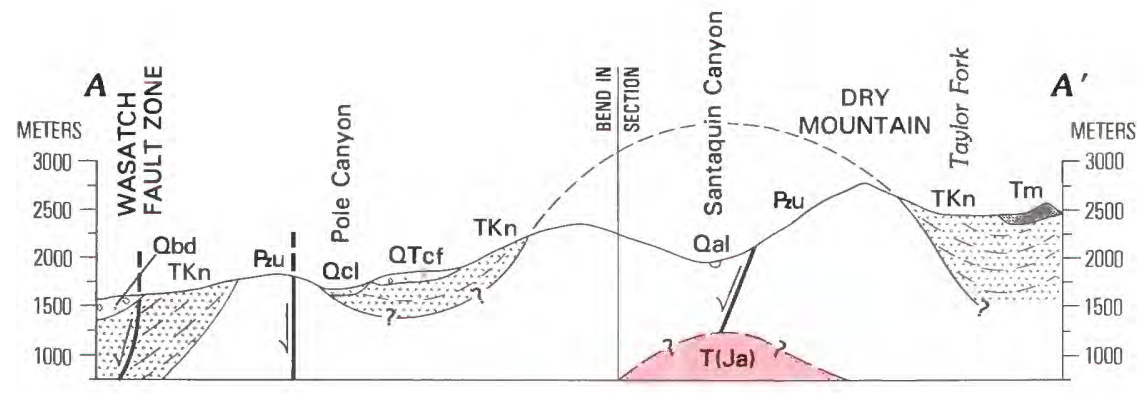

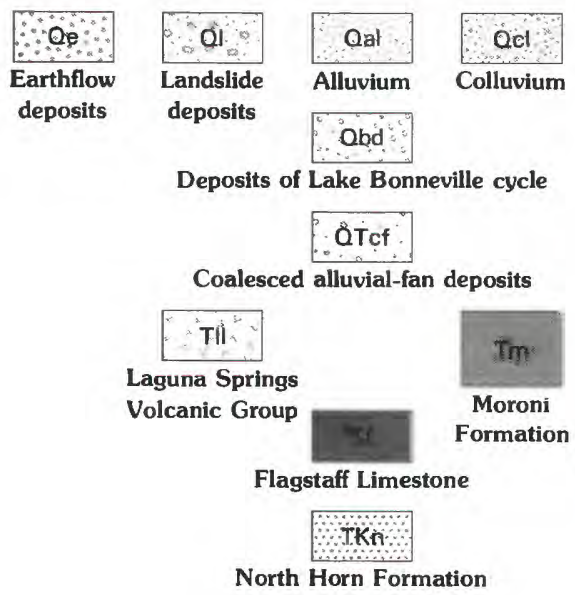

$\mathrm{P}_{2 \mathrm{H}}$

Paleozoic rocks, undivided

\section{EXPLANATION}

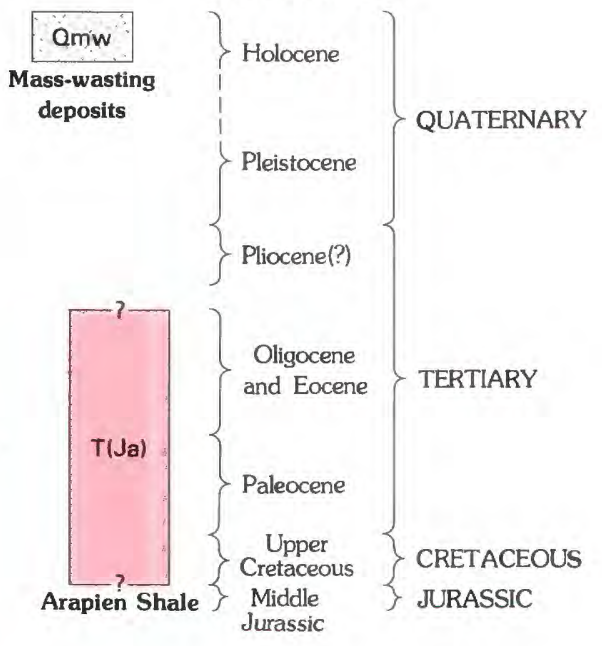

Contact-Approximately located or inferred; in cross section, dashed where inferred, queried where speculative ge of erosional escarpmentHachures point in general direction of inclination

Fault-Approximately located; bar and ball on downthrown block; dotted where concealed; hachures indicate modern fault scarp; barb shows downthrown block in cross section; dashed in cross section where reconstructed above eroded surface 
the overlying sedimentary units into mushroomshaped diapiric folds.

\section{SLOW UPWEI.LING}

The slow, upward movement of the salt diapir is expressed by the anomalous thinning of sedimentary units near the crests of the ancestral highs, much as discussed previously (p. 107-117). Locally, some of the units pinch out against the flanks of the high. Those units that continue unbroken across the crests of the highs, however, are the uppermost and younger parts of the formations. The lower and older parts of the formations presumably have pinched out against the slowly rising high. The fact that sequences of units thin must mean that the high was a dynamic feature growing continuously throughout lengthy episodes of geologic time. Were the paleohigh merely a static feature, the first units deposited against the flanks of the high might thin, but once the high was surmounted, subsequent units would pass over the crest of the high unchanged in thickness. This depositional thinning near the crests of the highs, found throughout the area, seems reasonably explained only as the result of slowly rising salt diapirs.

\section{RAPID, UPWARD, FORCEFUL SURGES}

In contrast to the slow, continuous movement, it is the repeated, forceful upward surges of the causative salt diapirs that appear to have determined the structural pattern of this part of central Utah. Salt is the motive force: It forces up the Arapien mudstones, which, in turn, force up and deform the overlying sedimentary units. These deformed sedimentary units, and their contained folded angular unconformities, reflect the repeated upward surges of the causative salt diapir. Expectably, the Arapien mudstones show many signs of extreme deformation; their present attitudes, however, merely reflect the last diapiric episode. Subsequent episodes will deform them once again.

FIGURE 59 (facing page).-Geology of an area near Dry Mountain. Geology slightly modified from Witkind (1987, fig. 12). Base modified from U.S. Geological Survey 1:100,000 Nephi (1981). Contour interval $250 \mathrm{~m}$. An underlying diapir appears to have arched the Charleston-Nebo thrust plate. North Horn (TKn) strata that flank north-trending Dry Mountain, part of the Charleston-Nebo thrust plate, dip eastward east of the range and westward west of the range. These opposing dips in the younger strata suggest that the Charleston-Nebo thrust plate was arched by an underlying diapir (cross section $A-A^{\prime}$ ).

\section{COLLAPSE OF DIAPIRIC FOLDS}

After the major folds were bowed up by the intrusive action of the Arapien Shale, they failed when salt was removed from the core of a diapiric fold. As the salt was removed, as a result of either extrusion or dissolution, the Arapien mudstone subsided into the newly formed void or voids. The failure probably occurred in small spasmodic movements, and not as a single catastrophic event.

Failure of the folds seems to have occurred either by collapse of the crestal part of the fold between high-angle normal faults, or by gradual subsidence of strata (outside the normal faults) to form monoclines (fig. 60). In some places both modes of failure may have occurred-downthrow along a high-angle marginal fault on one flank of a fold and downwarp on the opposite flank. Invariably, the downthrow or downwarp was toward the core of the fold.

In the ancestral Willow Creek (G-3) area (fig. 27), and along the northeast border of the Valley Mountains (G-2) (fig. 30), the crestal part of the fold probably collapsed between high-angle faults that formed along the fold's flanks (fig. 60A). A long, linear graben most likely resulted, probably much like those grabens that break the rocks along the crest and west flank of the Wasatch Plateau. This concept implies that the marginal faults that bound the graben extend to the base of the Arapien Shale but do not cut through the underlying Twin Creek Limestone on which the Arapien rests. My examination (through the courtesy of Chevron, USA) of seismic reflection profiles that cross the Wasatch Plateau convinces me that those faults that bound large grabens, such as the Joes Valley graben, do not, in fact, extend below the base of the Middle Jurassic Arapien Shale or its correlative, the upper part of the Carmel Formation.

Elsewhere, as near the mouth of Sixmile Creek canyon (F-4), along the west flank of the Wasatch Plateau (fig. 21), and in Red Canyon (E-2), along the east flank of the Valley Mountains (fig. 31), the folds appear to have failed by gradual subsidence and so formed monoclines (fig. 60B; and Witkind and Page, 1984). Thus, I interpret the westward-facing Wasatch monocline, and the much smaller, unrelated, eastward-facing Valley Mountains monocline, along the east flank of the Valley Mountains, to stem from such subsidence.

As the diapiric core subsided, in response to the removal of salt, the overlying sedimentary and volcanic strata subsided into the resultant void to form a broad V, forming, thus, a pair of facing monoclines. The resultant feature is best visualized as a 

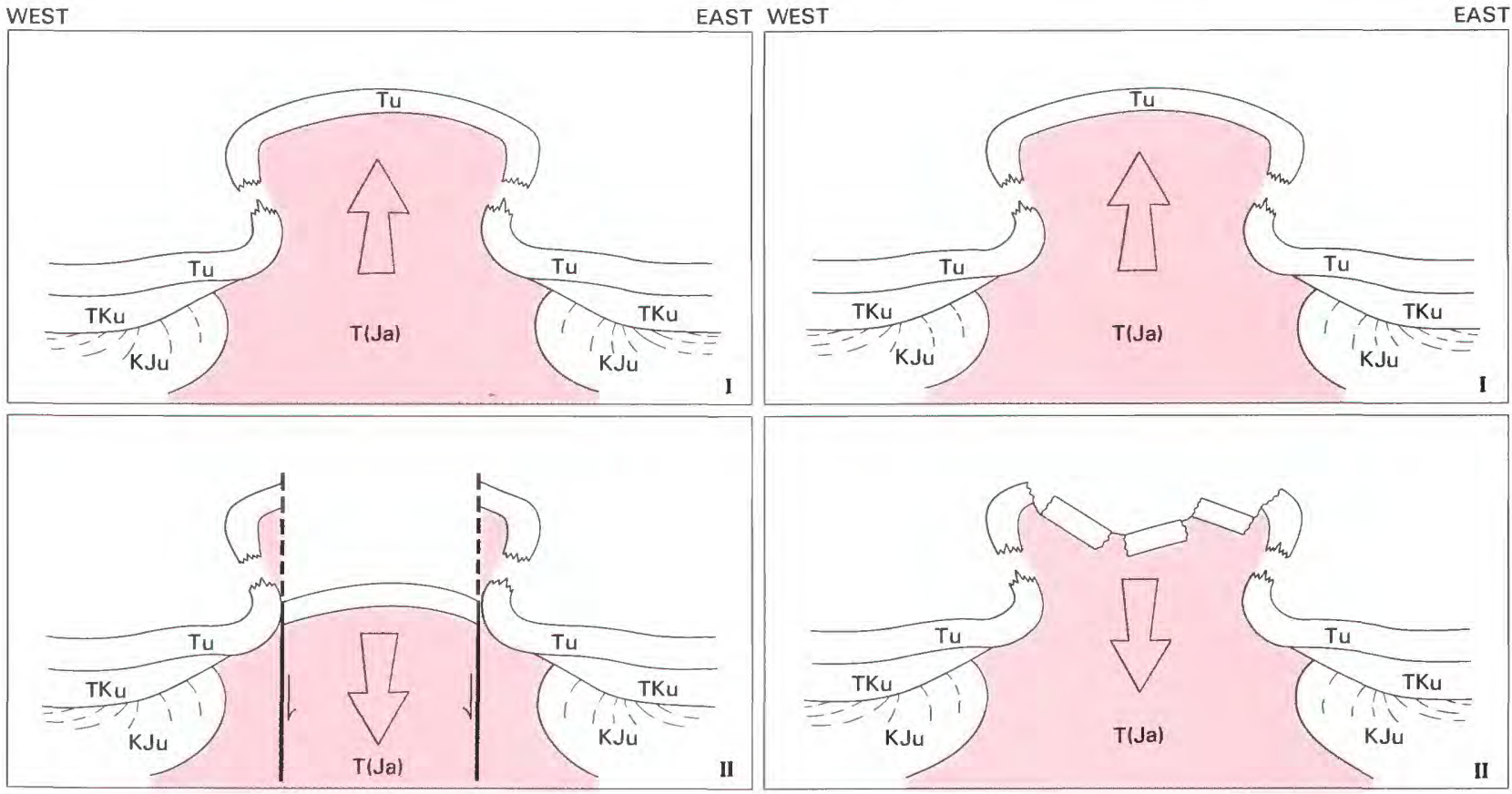

A

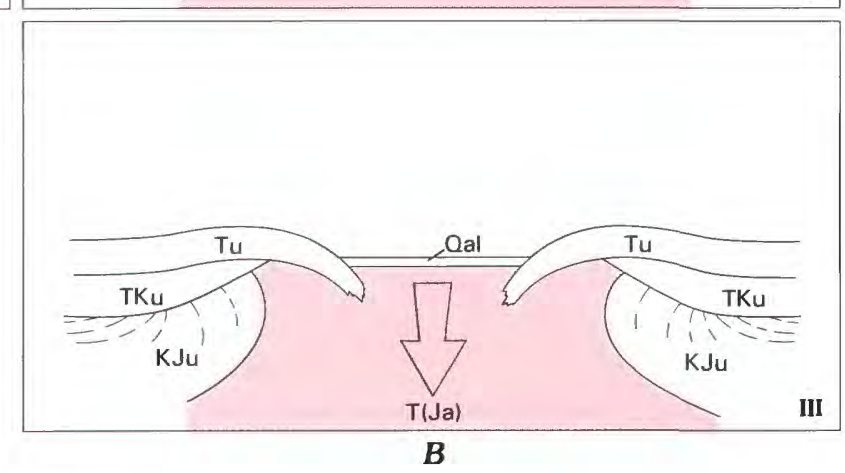

EXPLANATION

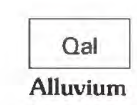

Tu

Tertiary rocks, undivided-Includes, in descending order, Crazy Hollow Formation, Green River Formation, and Colton Formation, and Flagstaff Limestone

Tertiary and Cretaceous rocks, undivided-Includes, in descending order, North Horn Formation and Price River Formation

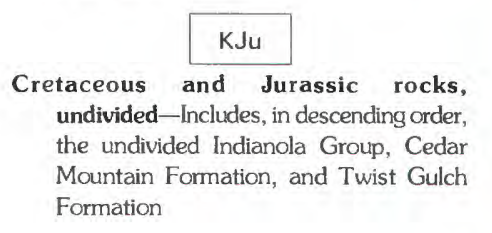

Arapien Shale
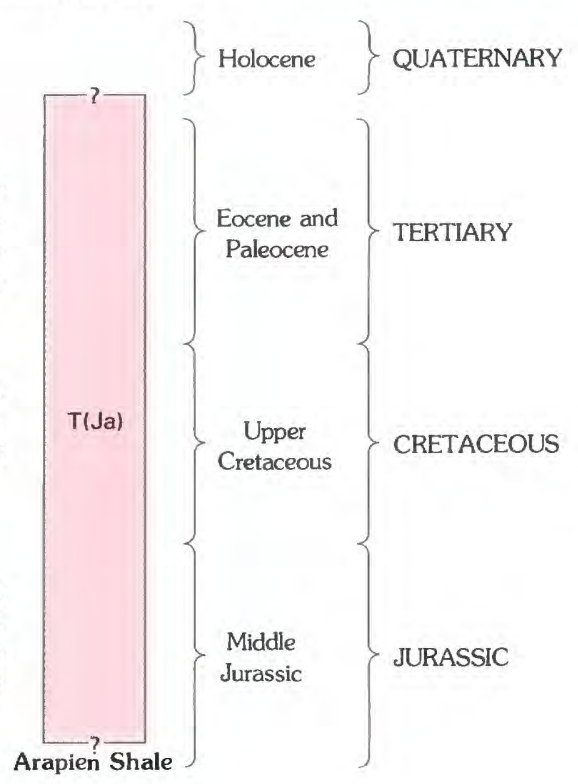
collapse structure, for the formerly continuous strata that overlay the diapir were broken and disrupted as they subsided. The structure, thus, differs from a syncline, which is formed by downwarped but essentially unbroken strata. Doelling (1988, p. 45, figs. 46 and 49) referred to somewhat comparable collapse features developed in the Paradox Basin, and essentially similar in size to those within the SanpeteSevier Valley area, as "**** $\mathrm{v}$-shaped dissolution synclines ***," or "V-synclines."

\section{PAIRED, FACING MONOCLINES}

If the monoclines in the Sanpete-Sevier Valley area are indeed the result of subsidence stemming from removal of salt, one would expect to find paired, facing monoclines-one facing east even as its opposite number faces west. In places, that appears to be the case. So, the eastward-facing Valley Mountains monocline is paired with the westward-facing West Gunnison monocline developed along the southwest flank of the Gunnison Plateau. Sevier Valley separates the two monoclines (fig. 61). In like fashion, the eastward-facing West Hills monocline, which delineates the east flank of the West Hills, is paired with the northern part of the westward-facing West Gunnison monocline. Juab Valley separates the two monoclines.

Farther to the east, the westward-facing Wasatch monocline then should be paired with another monocline across Sanpete Valley, one that faces east and

FIGURE 60 (facing page).-Diagrammatic sections illustrating two alternative interpretations of how diapiric folds may fail. In each view, west is at left, east is at right.

$A$, The crest of a fold collapses and a linear graben is formed.

I. Fan-shaped diapiric fold is formed as a result of the upward thrust (large arrow) of Arapien mudstones-a direct result of the upward movement of a salt diapir (not shown).

II. With gradual removal of salt, by either extrusion or dissolution, the underlying support for the Arapien mudstones is removed, and they and the overlying strata collapse (large arrow) along high-angle faults formed along both flanks of the fold's crest. (Barbs show relative movement along faults.) The end result is a long, linear graben comparable to those that break the rocks along the crest and west flank of the Wasatch Plateau. $B$, The central part of a fold gradually subsides, and facing monoclines are formed.

I. A fan-shaped diapiric fold is formed.

II. With gradual removal of salt, the Arapien mudstones, lacking support, sink into the newly created voids; the overlying sedimentary strata founder and break into large masses. Erosion quickly destroys these fragmented blocks.

III. Continued removal of salt and the concurrent subsidence of the Arapien mudstones eventually cause downward flexing of previously upturned beds to form paired, facing monoclines. that delineates the east flank of the Gunnison Plateau. Rather than a monocline, however, a northward-trending belt of upturned and locally overturned Cretaceous and Jurassic rocks marks the lower flank of the plateau. ${ }^{4}$ All sedimentary units within this distinctive belt are anomalously thin. Analogous structures elsewhere in the area imply that this belt may once have lain beneath a former monocline. Similar, anomalously thin Cretaceous and Jurassic rocks are exposed in both the Wasatch and Valley Mountains monoclines, where the downwarped Tertiary beds have been breached (Witkind, 1992). In both those areas, the upturned "Cretaceous" rocks are complexly deformed, and all strata, upturned "Cretaceous" and downwarped Tertiary, are anomalously thin compared with their thicknesses elsewhere in the area. Specifically, where the foot of the Valley Mountains monocline is breached at its north end, the sedimentary units exposed at Red Canyon are both structurally complex and remarkably thin. Similarly, where the foot of the Wasatch monocline is breached at the mouth of Sixmile Creek canyon, the exposed rocks are both unusually complex structurally and atypically thin.

Locally, this same pattern-downwarped Tertiary beds overlying upturned "Cretaceous" rocks-is exposed along the West Gunnison monocline. In that sector, too, the Cretaceous and Tertiary rocks display the anomalous thinness seen elsewhere, but not the striking structural complexity. I attribute this apparent absence of structural complexity to the fact that erosion has not cut deeply enough to expose the underlying vertical to overturned beds (fig. 62A). Weiss (in Witkind, Weiss, and Brown, 1987) and Mattox and Weiss (1987) have assigned the clastic beds beneath North Horn strata and exposed along the southwest flank of the Gunnison Plateau to the Indianola Group. I believe that the beds in question, rather than being part of the Indianola, are more correctly part of the Price River Formation. In lithology, appearance, and attitude, the beds in question are very much like the Price River strata that overlie vertical to overturned beds of the Indianola Group exposed along the east flank of the Gunnison Plateau north of Wales (fig. 62B, and fig. 17). Thus, in my view, erosion has not cut deeply enough along the west flank of the Gunnison Plateau to expose the

${ }^{4}$ The bowed up strata include, in various localities, Middle Jurassic (Twist Gulch Formation), Lower Cretaceous (Cedar Mountain Formation), Upper Cretaceous (Indianola Group, Price River Formation), and Upper Cretaceous and Paleocene units (North Horn Formation). For ease of discussion I group these beds and refer to them as "Cretaceous" in this discussion. 


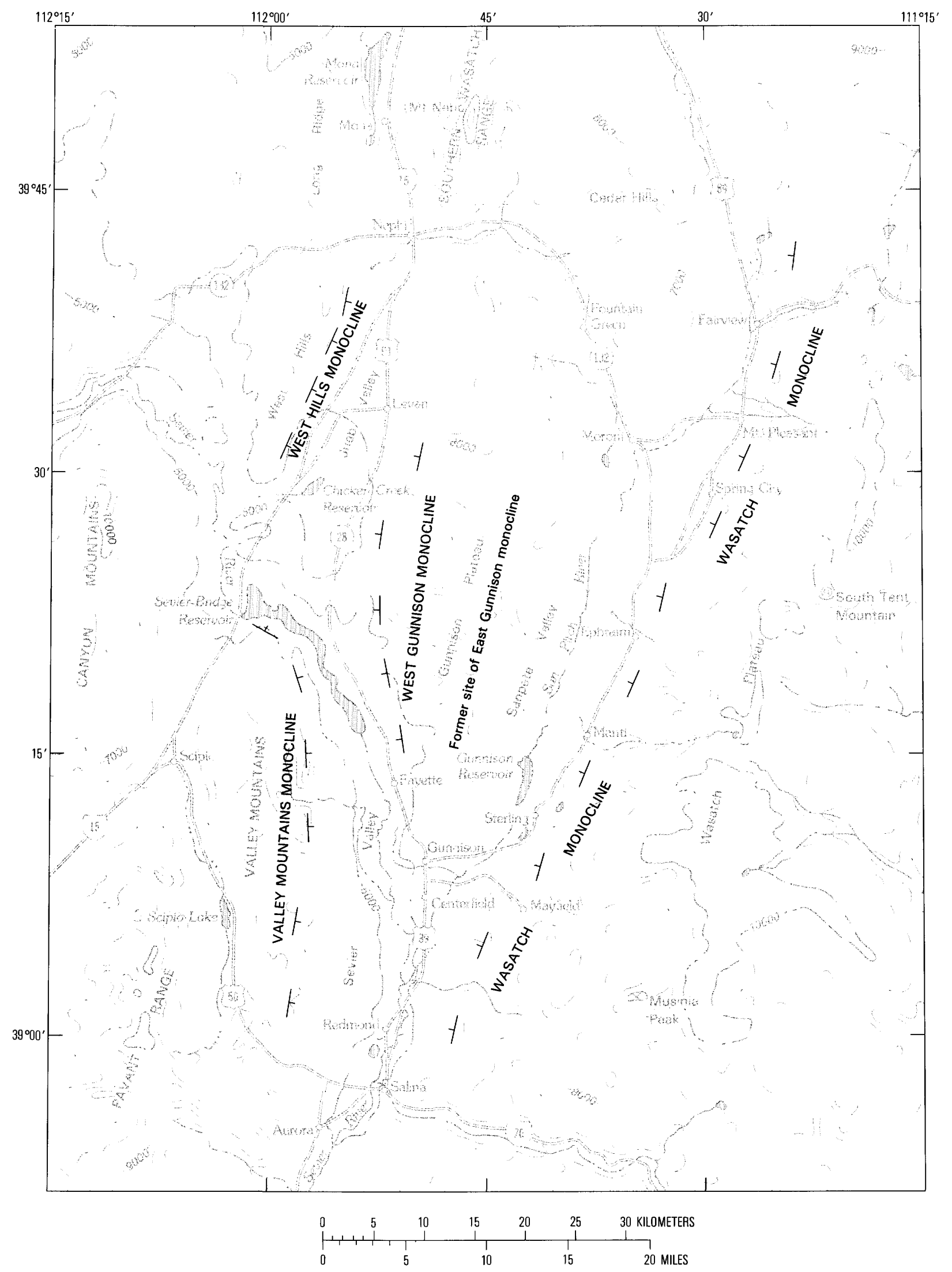


FIGURE 61 (facing page).-Paired, facing monoclines in the Sanpete-Sevier Valley area formed as the result of removal of salt from an underlying diapir. East-facing Valley Mountains monocline is paired with the west-facing West Gunnison monocline, across Sevier Valley. East-facing West Hills monocline is paired with north end of the west-facing West Gunnison monocline. A now completely eroded and removed monocline marking the east flank of the Gunnison Plateau-the East Gunnison monocline-is postulated to pair with the Wasatch monocline. Of major Neogene monoclines trending northward through the Sanpete-Sevier Valley area, only the Wasatch and Valley monoclines are essentially whole and only slightly eroded. Only remnants of the West Gunnison monocline are left to indicate its former extent, and the East Gunnison monocline, completely eroded, can only be inferred. Base modified from U.S. Coast and Geodetic Survey 1:500,000 Grand Junction (T-3) Sectional Aeronautical Chart (1954; rev.).

underlying Indianola strata. Were those Indianola strata exposed, I believe their attitudes-vertical or dipping steeply toward the east-would mimic those exposures along the east flank of the plateau (fig. 62).

Seemingly, the monoclines in the Sanpete-Sevier Valley area differ from most monoclines. A section through any monocline within the Colorado Plateau displays a sequence of stacked, layered beds that conform in attitude to those beds that form the monoclinal slope. It is much like a section through an onion. By contrast, a section through a monocline in central Utah does show the characteristic layered aspect in the upper and middle parts of the monocline, but not in the distal end-the foot-of the monocline. Those beds exposed at the foot of the monocline, beneath the downwarped Tertiary strata that define

FIGURE 62.-Diagrammatic cross sections showing suggested geologic relations along both east and west flanks of Gunnison Plateau, a southward-plunging syncline. A, West flank of the Gunnison Plateau. In general, Cretaceous strata that dip eastward along the west flank of the plateau are overlain with angular unconformity by westward-dipping Tertiary strata. These Tertiary beds form the much-dissected westward-facing West Gunnison monocline. Units here labeled Price River(?) Formation have been called the Indianola Group by Mattox and Weiss (1987). $B$, East flank of the Gunnison Plateau. In general, Cretaceous strata dip westward along the east flank of the plateau. I contend that these strata were once overlain with angular unconformity by eastward-dipping Tertiary strata that formed the East Gunnison monocline, now completely eroded. $C$, East flank of the Gunnison Plateau. Locally, the Cretaceous beds that crop out along the east flank of the plateau have been warped up into vertical and overturned attitudes. Near Wales (D-4), for example, Price River strata, which dip gently westward near the mouth of Maple Canyon (E-3), are overturned and form a prominent ridge that parallels the front of the plateau. See figure 17, and figure 23A. For an explanation of how these relations developed, see figure 25 . the monoclinal slope, are both anomalously thin and unusually complex structurally.

It seems more than fortuitous that in three widely separated areas-(1) Red Canyon in the Valley Mountains, (2) Sixmile Canyon along the west flank of the Wasatch Plateau, and (3) the lower flanks of the east side of the Gunnison Plateau-the exposed rocks display both unusual structural complexity and atypical thinness. The one great difference among the three areas is the absence of a monocline along
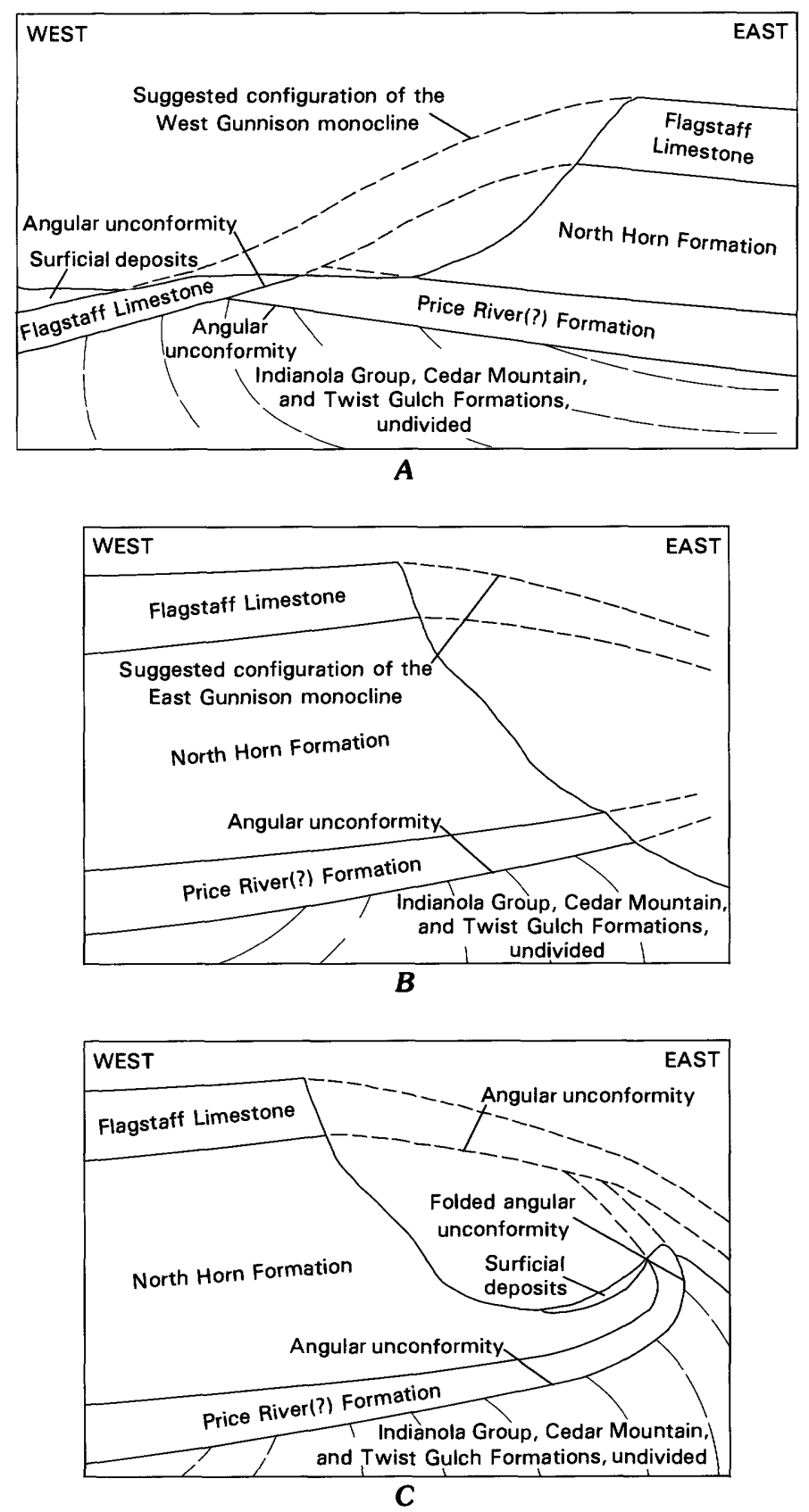
the east flank of the Gunnison Plateau; that absence can be attributed to erosion. It is this similarity between the beds exposed in the breached sectors of recognizable monoclines and comparable beds exposed along the east flank of the Gunnison Plateau that has led me to propose that the near-horizontal Tertiary units that cap the Gunnison Plateau once flexed down along the east flank of the plateau to form an eastward-facing monocline (fig. 62B). I refer to this monocline as the East Gunnison monocline, and it must have been every bit as impressive as the Wasatch monocline.

During middle and late Tertiary time, then, the geomorphic pattern of the Sanpete-Sevier Valley area was probably dominated by at least four major north-trending monoclines (fig. 61). From east to west, these were (1) the Wasatch monocline, facing west; (2) the East Gunnison monocline, facing east; (3) the West Gunnison monocline, facing west; and (4) the Valley Mountains and West Hills monoclines, facing east. The Wasatch-East Gunnison monoclines formed a facing pair separated by Sanpete Valley; the West Gunnison-Valley Mountains and West Hills monoclines formed a second facing pair separated by the lowland formed by the collinear alignment of Sevier and Juab Valleys.

\section{DIAPIRIC STAGES AND EPISODES}

The diapiric folds have grown and collapsed repeatedly. Figure 63 illustrates this repeated growth and collapse of diapiric folds. In this figure, I have, for ease of understanding, assumed that the folds collapse between parallel crestal faults. As noted in figure $60 \mathrm{~B}$, the folds may also fail by gradual subsidence.

A diapiric fold grows and collapses in three successive, interrelated stages, which together make up a diapiric episode. The first stage-the intrusive stageis characterized by the rapid upwelling of a salt diapir that forces up the mobile mudstones of the Arapien Shale. These, in turn, acting much like a viscous magma, intrude, bow up, and fold back the overlying sedimentary beds (fig. 63 , II). The resultant fan-shaped diapiric fold is probably partly destroyed, even as it rises, by gravity sliding and other forms of mass-wasting. Nevertheless, the end result is a topographic high.

This stage is followed almost immediately by the onset of the second stage, during which the fold fails, presumably owing to removal of the salt (fig. 63, III). The remnants of the collapsed fold are then eroded to form a broad, even-surfaced plain of low relief (fig. 63, IV). During this second stage-the erosional stagethe salt diapir probably resumes its slow upwelling, but its upward movement must be so slight that erosion is able to keep pace with whatever doming occurs.

The third stage begins with the deposition of sediments on this newly formed erosion surface (fig. 63, V). During this stage-the depositional stage-the salt diapir wells upward rapidly enough to restrict the amount of sediment deposited across the crest of the rising fold, resulting in depositional thinning. This third stage ends with a renewed upward surge of the salt diapir-the intrusive stage in yet another episode of salt diapirism (fig. 63, VI).

I term each cycle of growth and collapse a diapiric episode; thus, each episode comprises three distinguishable diapiric stages. Three such major diapiric episodes are well shown in the Red Rocks (F-3)Sixmile Canyon (F-4) area along the east flank of the Gunnison Plateau, and in the Red Canyon (E-2) area of the Valley Mountains.

1. Late Cretaceous-early Paleocene episode:

The first clearly recognized diapiric episode probably began during the Late Cretaceous, after deposition of the Indianola Group, and probably ended in the early Paleocene after deposition of the North Horn Formation but before deposition of the Flagstaff Limestone.

The Twist Gulch and Cedar Mountain Formations, and the Indianola Group, bowed up during this first intrusive stage (fig. 63, II), were subsequently eroded to form a surface of low relief during the first erosional stage (fig. 63, IV). Later, the Price River and North Horn Formations were deposited on this surface of low relief during the first depositional stage (fig. 63, V).

2. Early Paleocene-late Oligocene(?) episode:

The second episode probably began in early Paleocene time, after deposition of the North Horn Formation, and ended after deposition of the Crazy Hollow Formation, possibly during the late Oligocene or Miocene.

The North Horn and Price River Formations were bowed up during a second intrusive stage (fig. 63, VI). Subsequently, erosion reduced the newly formed diapiric folds to a surface of low relief by the end of the second erosional stage (fig. 63, VIII). A sequence of Tertiary units, extending from the Flagstaff Limestone to at least the Crazy Hollow Formation, was deposited on this surface during the second depositional stage (fig. 63, IX).

3. Late(?) Oligocene-Pliocene(?) episode:

The third episode probably began during the late Oligocene or Miocene, after deposition of the Goldens Ranch and Moroni Formations, and may have ended during the Pliocene or Pleistocene. The evidence as to 
when this episode ended is fragmentary and inconclusive.

Locally, the Tertiary units (Flagstaff, Colton, Green River, and Crazy Hollow) were bowed up during a third intrusive stage (fig. 63, X). The folds failed in various ways, some by collapse (fig. $63, \mathrm{XI}$ ), and some by subsidence. Erosion, however, has not as yet completely beveled the diapiric folds, and most now appear in varying stages of dissection (fig. 63, XII).

I believe that each of these three episodes was regional in extent, and that during each episode all the salt diapirs in central Utah reactivated and deformed the overlying beds. The evidence in the Gunnison Reservoir (F-3) area (fig. 28) suggests that a fourth, localized diapiric episode began and may have ended during the Pleistocene or Holocene.
Although all three stages of all three episodes are clearly shown in some exposures, elsewhere erosion has not cut deeply enough. Thus, in the ancestral Willow Creek (G-3) area (fig. 27), only that vestige of the Sanpete-Sevier Valley diapiric fold formed during the third diapiric episode (late Oligocene-Pliocene(?)) is exposed; erosion has not yet uncovered the earlier versions of the fold formed during the first (Late Cretaceous-early Paleocene) and second (early Paleocene-late(?) Oligocene) episodes.

\section{GEOLOGIC PATTERN}

The three major episodes of diapirism have stamped a geologic pattern on the area that is repeated in place after place. In its simplest form this pattern is represented by upturned conglomerate
FIGURE 63 (following pages),-Schematic sections suggesting how the repeated growth and collapse of diapiric folds have determined the structural pattern of central Utah. All sections represent part of the west limb of a typical diapiric fold.

I. Jurassic and Cretaceous sediments (KJu) were deposited on the Arapien Shale. Slow upwelling of the salt diapir (just east of area of section shown) pushed up the Arapien mudstones to form an elongate, north-trending arch, which impeded deposition of the sediments. As the arch continued to rise, all sediments that were deposited against its flanks or across its crest thinned or pinched out.

First diapiric episode (Late Cretaceous to early Paleocene):

II. Late Cretaceous intrusive stage. A sudden upward surge of the salt diapir (not shown) pushed up the mudstones and shales of the Arapien Shale (K(Ja)), which in turn bowed up and folded back (arrow) the overlying sedimentary strata (KJu) to form a fan-shaped fold. (Much of the overturned limb was soon destroyed by gravity sliding and other forms of mass-wasting.)

III. Late Cretaceous erosional stage. Removal of the salt core (chiefly by solution) caused the central part of the fold to collapse, forming a graben between high-angle normal faults. Only the western fault (A) is shown here.

IV. Late Cretaceous erosional stage. Erosion of fold remnants produced a surface of low relief. Persistent slow upwelling of the salt diapir arched the deformed strata (KJu) slightly. The fault (A), formerly vertical, is tilted. The rate of erosion either exceeded or at least kept pace with the rate of arching.

V. Late Cretaceous-early Paleocene depositional stage. Upper Cretaceous sediments deposited on the eroded surface subsequently were buried beneath lower Paleocene sediments (TKu). The continued slow upwelling of the salt diapir warped up the deformed strata $(\mathrm{KJu})$, further tilting the previously vertical fault (A), and thinning those sediments (TKu) deposited across the crest of the fold.

Second diapiric episode (early Paleocene-late Oligocene(?) episode):

VI. Early Paleocene intrusive stage. Reactivation of the salt diapir during the early Paleocene resulted in a renewed diapiric fold, whose general trend and position followed that of the earlier fold (II). The recently deposited Cretaceous and Paleocene strata ( $T K u)$ were flexed into a fan-shaped fold, and the older strata (KJu) were tilted to still steeper angles. Fault (A) was probably destroyed by the renewed movements of the mobile mudstones and shales of the Arapien Shale $(\mathrm{T}(\mathrm{Ja}))$; it is shown here to emphasize the tilting of the strata. Here too, as for the earlier fold, the overturned limb of the developing fold was probably destroyed in great part by gravity sliding.

VII. Middle(?) Paleocene erosional stage. Removal of the salt core, possibly during the middle Paleocene, resulted in collapse of the crest of the fold along high-angle normal faults. Only the western fault (B) of those faults that bound the graben thus formed is shown here. The pattern of collapse of the parental fold (III) is repeated. Near the core of the fold, the undivided Tertiary and Cretaceous strata (TKu) overlay the overturned undivided Cretaceous and Jurassic strata (KJu) with profound angular unconformity. A short distance to the west the two units are disconformable, and still farther away they are conformable. VIII. Middle(?) Paleocene erosional stage. Erosion again reduced the area to a widespread surface of low relief. The slow upwelling of the salt diapir resumed and the strata were again arched. Erosion kept pace with the upward bowing of the consolidated units.

IX. Late(?) Paleocene to late(?) Eocene depositional stage. The pattern recurs. Beginning in the late(?) Paleocene and continuing through the late Eocene and probably even into the Oligocene, sediments (Tu) were deposited on the newly formed erosion surface. The slow rise of the salt diapir arched the consolidated strata (KJu, TKu), tilted the faults (A, B), and thinned the sequence of those sedimentary units being deposited across the axis of the fold.

Third diapiric episode (late(?) Oligocene-Pliocene episode):

$\mathrm{X}$. Late(?) Oligocene intrusive stage. The salt diapir reactivated for a third time; again a new fold formed, and again it lay along the same site and had the same trend as that of the previous folds. The time of this reactivation may have been during the late(?) Oligocene or possibly even the Miocene. The newly deposited Tertiary strata ( $\mathrm{Tu}$ ) were raised and folded back by the remobilized mudstones of the Arapien Shale to form a fan-shaped fold. The overturned limb of the fold was concurrently destroyed by gravity sliding and mass wasting.

XI. Late(?) Oligocene-Pliocene erosional stage. The newest formed fold was destroyed by collapse of the crest of the fold along high-angle normal faults. Fault $\mathrm{C}$ is the westernmost of the faults that bounded the newly formed graben.

XII. Late(?) Oligocene-Pliocene erosional stage; ancestral topography. Erosion began to reduce the fold, even as the sedimentary beds were raised and arched by continued slow upwelling of the salt diapir. 

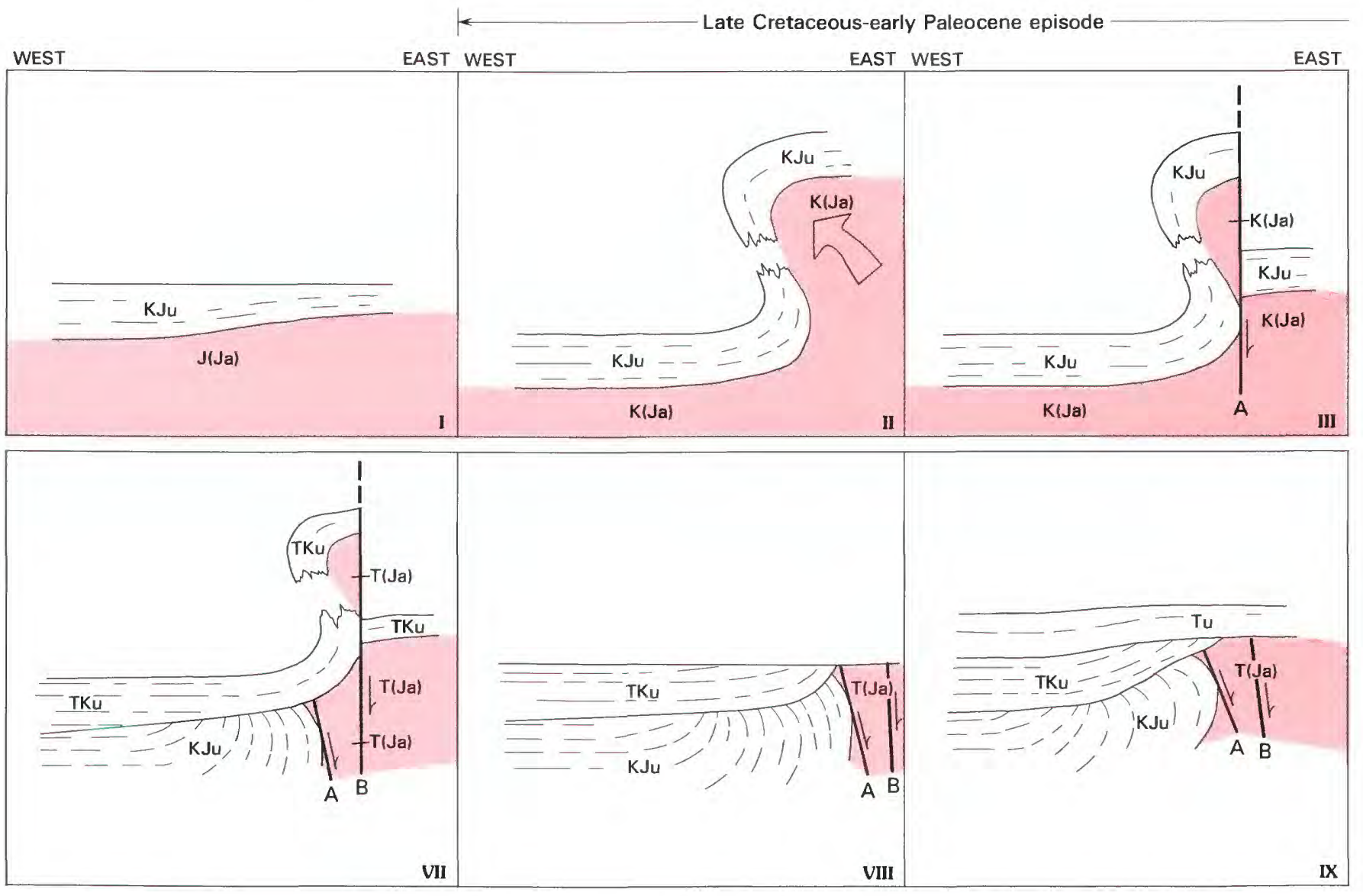

Early Paleocene-late Oligocene(?) episode

EXPLANATION
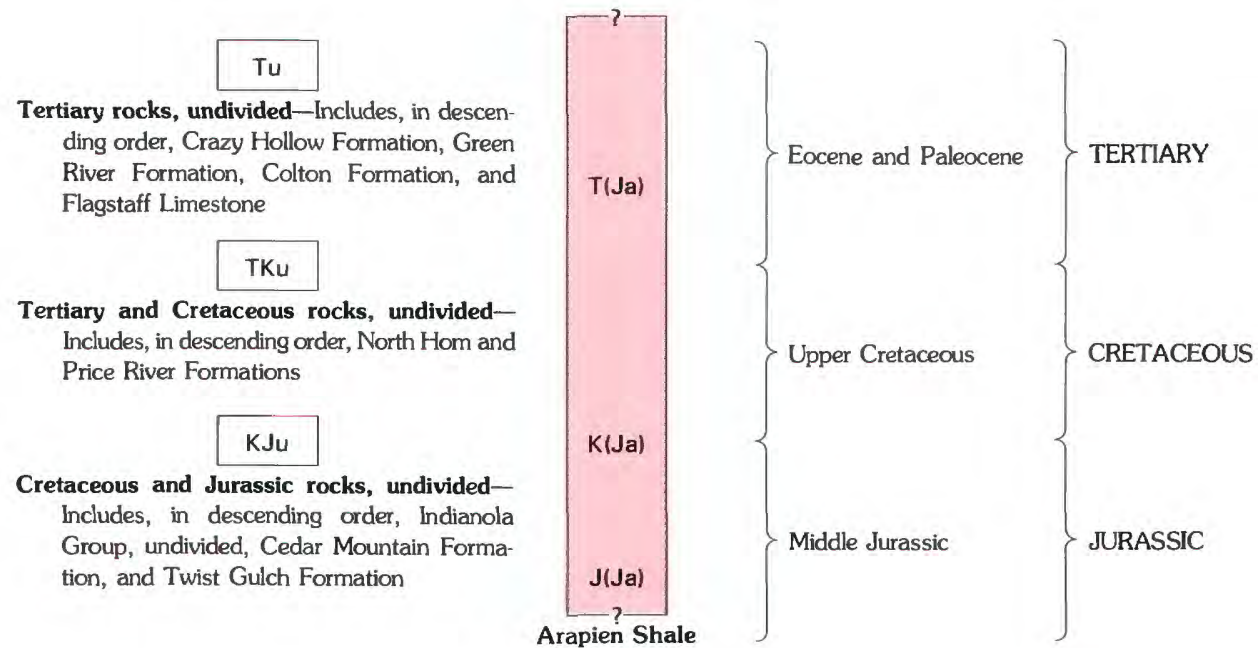

beds of the Indianola Group unconformably overlain by thin Price River and North Horn Formations, which in turn are unconformably overlain by the
Flagstaff Limestone. The two angular unconformities commonly are folded, and they are distinctive in the stratigraphic sequence. This geologic pattern is well 


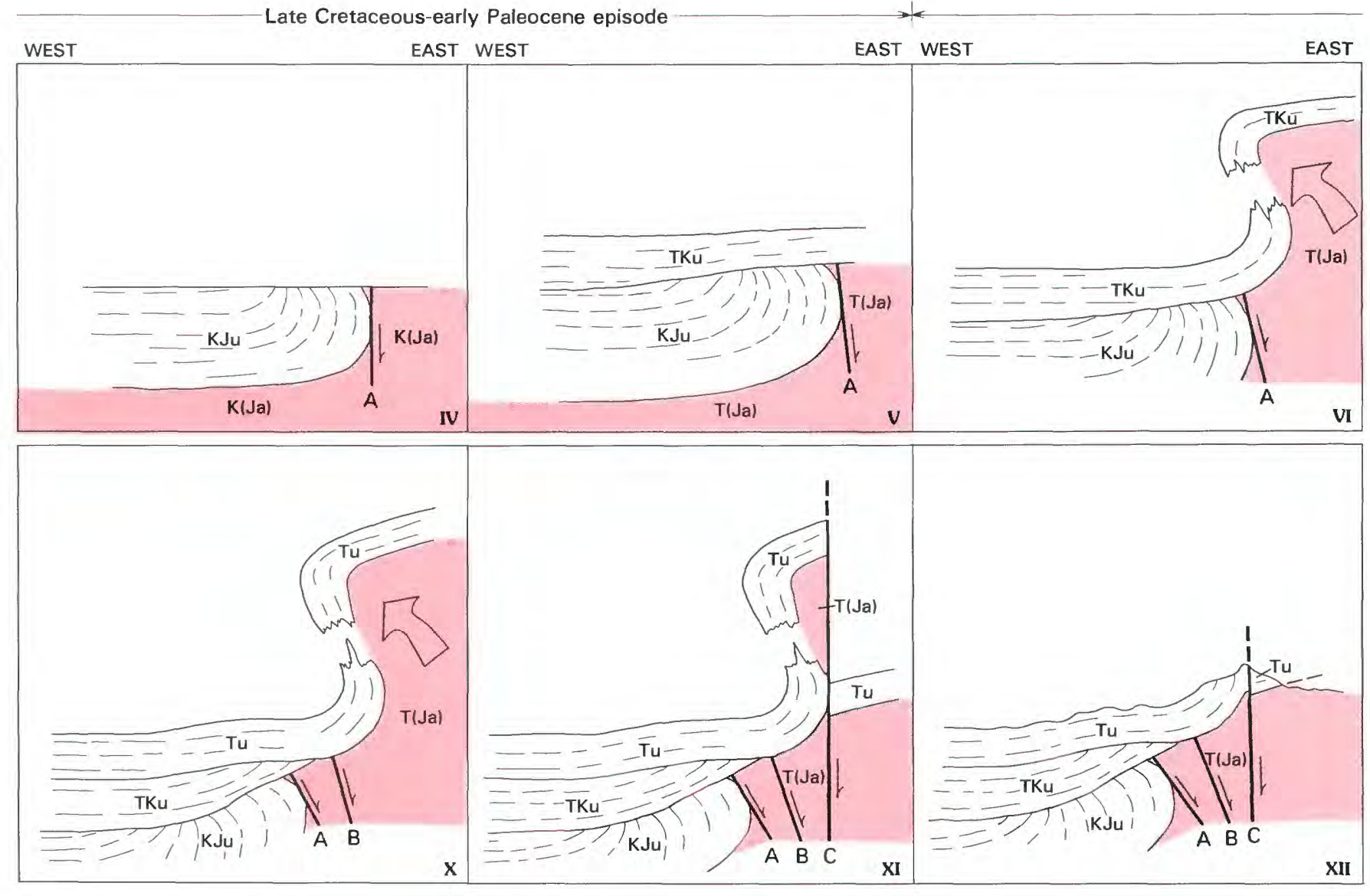

F

Late(?) Oligocene-Pliocene(?) episode

exposed at the mouth of Sixmile Creek canyon (F-4), in Red Canyon (E-2) (along the northeast flank of the Valley Mountains), and-not quite as easily recognizable-along the east and west flanks of the Gunnison Plateau.

How much of this geologic pattern is exposed depends to a great extent upon how deeply an area has been eroded. As exemplified in figure 64, if erosion has cut a deep valley through the "ancestral surface," the geologic pattern is easily recognizedupturned beds of the Indianola Group and older rocks (KJu) unconformably overlain by thin Price River and North Horn sequences (TKu), which in turn are unconformably overlain by the Flagstaff Limestone and younger Tertiary strata (Tu). If, however, erosion has cut deeper and reached the "modern surface," much of the structural complexity has been removed - the geologic pattern can only be inferred.

The angular unconformities, in which near-vertical beds are overlain by near-horizontal beds, appear to be present only near the core of a diapiric fold. As one moves away from the core, the near-vertical beds lessen in dip and several kilometers (a mile or so) away are conformable with the overlying units. So, for example, in the Red Rocks (F-3) area, which is about $1 \mathrm{~km}(0.5 \mathrm{mi})$ west of the core of the diapiric fold, the lower angular unconformity (between the Price River and North Horn and the Indianola) is well exposed, but the upper unconformity (between the Flagstaff and North Horn strata) is not easily recognized (Spieker, 1949, p. 76). Here, the FlagstaffNorth Horn contact appears as a disconformity; erosion has removed that part of the fold in which the angular unconformity between the Flagstaff and the North Horn was well displayed.

By contrast, in the Sixmile Creek canyon (F-4) area, which is about $4 \mathrm{~km}(2.5 \mathrm{mi})$ east of the crest of the fold, the lower unconformity is not as impressive as it is in the Red Rocks area, for the Price River and units in the Indianola (Sixmile Canyon Formation, in particular) are separated by only a slight angular unconformity; the beds flatten rapidly eastward and are conformable only about $1 \mathrm{~km}(0.5 \mathrm{mi})$ away. The upper unconformity, however, does catch the eye, for 

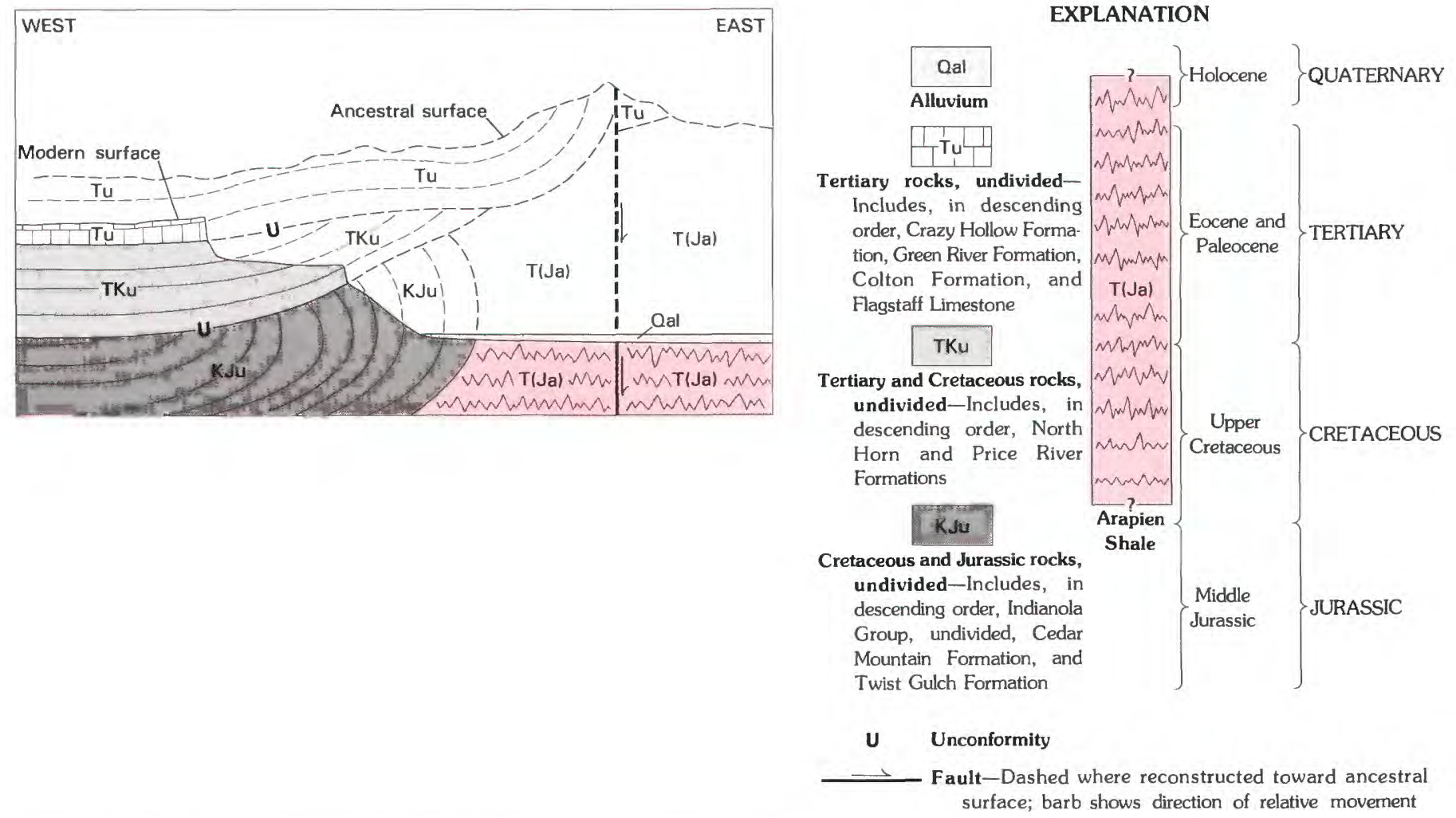

Figure 64.-Cross section of typical diapiric fold in central Utah, illustrating how the extent of erosion can influence interpretation of a geologic pattern. Vertical and overturned beds of the Indianola Group and older units are unconformably overlain by a Price River and North Horn sequence, which in turn is unconformably overlain by a Tertiary sequence of which the Flagstaff Limestone is the oldest. Two distinctive angular unconformities are produced. If erosion is at the "ancestral surface" level, both unconformities are exposed and geologic relations are unequivocal. If erosion has cut to the "modern surface" level shown, only one unconformity can be recognized, and the younger unconformity is removed or masked. Compare this illustration with figure 63, XII, and with photograph of the Red Rocks area, figure $18 B$ the westward-tilted Flagstaff Limestone rests upon the upturned eastward-tilted beds of the Price River and North Horn sequence (fig. 21).

The same geologic pattern is clearly visible in Red Canyon (E-2) along the northeast flank of the Valley Mountains. Near-vertical beds of the Indianola Group are overlain with angular unconformity by the North Horn Formation that dips west at a moderate angle. The North Horn, in turn, is overlain by beds of the Flagstaff Limestone that dip eastward (fig. 31). The exposure is a mirror image of the one in Sixmile Creek canyon (F-4) (Witkind and Page, 1984).

Only part of the pattern is exposed along the east flank of the Gunnison Plateau. At and near the mouth of Maple Canyon (C-4), Price River strata, dipping gently to moderately westward, unconformably overlie vertical to overturned Indianola beds, duplicating stratigraphic relations found in the Red Rocks ( $F-3)$ area, and in the Red Canyon area of the Valley Mountains. Erosion, however, has removed much of the North Horn and all of the Flagstaff
Limestone from the Maple Canyon area; the Flagstaff now crops out along the top of the plateau about $1.6 \mathrm{~km}(1 \mathrm{mi})$ to the southwest, far back from the crest of the diapiric fold. The Flagstaff, expectably, conformably overlies North Horn strata. Here too, then, much as in the Red Rocks area, that part of the fold (near the diapiric crest) where the Flagstaff and the North Horn were once separated by an angular unconformity has been removed by erosion.

In a few localities, an additional complexity, stemming from the collapse of a diapiric fold, has somewhat modified this geologic pattern. Along the northeast flank of the Valley Mountains, northwest of Painted Rock Canyon (E-2), younger beds are downthrown along a range-front, high-angle normal fault and abut the much older Indianola beds. Relations are confused, but in general, it appears that elements of the North Horn, Flagstaff, Colton, and Green River formations are juxtaposed against the conglomerates of the Indianola Group (fig. 29B). I interpret these relations to result from the collapse of 
the crestal part of the Sevier Bridge Reservoir diapiric fold.

\section{CYCLICAL ASPECTS}

The fact that the three diapiric episodes are represented in single outcrops at several different localities implies that ever-younger diapiric folds were formed time and again in the same structural zones and had the same trends as the earlier diapiric folds. In essence, the "parental" diapiric folds that were formed in Late Cretaceous time (and that are represented by the beveled, steeply inclined beds of the Indianola Group) were the precursors of other folds formed still later, once during the Paleocene, and again during the late(?) Oligocene or Miocene. It is much as if the salt was confined to specific conduits and repeatedly used these conduits each time it surged upward.

\section{LOCALIZATION AND CAUSATIVE FORCES}

The diapiric folds in central Utah, the "salt anticlines" (salt-cored anticlines) of the Paradox Basin, the elongate salt-cored structures of northern Germany (Trusheim, 1960; Sannemann, 1968), and northern Tunisia (Perthuisot, 1981), to select but a few examples, are all alike in that they are strikingly regular in distribution and orientation. This regularity of the salt structures in northern Germany was attributed by Trusheim (1957) to autonomous, isostatic salt movement, for which he coined the term "halo-kinesis." In brief, he proposed that as soon as deeply buried salt begins to flow, it forms a low, swelling salt mass (Trusheim, 1960, p. 1524-1527). Adjacent salt from the "mother bed" of salt moves inward toward the salt mass, which begins to expand and forms a mound. Even as this occurs, the sedimentary rocks adjacent to these areas of inflowing salt subside to form rim synclines. Sedimentary material, deposited in these rim synclines, adds weight, which augments the inflow of the salt toward the salt mass. As the salt mass swells, it arches the overlying strata, and in time, the swelling salt mass, fed by a continuous supply of mother salt, intrudes the overlying sedimentary beds, starting the diapiric stage. With continued addition of salt, the diapir may breach the sedimentary cover, and flow out across the surface. A new rim syncline, formed adjacent to this diapir, is gradually filled as sediments accumulate in it. In time, these sediments are thick and dense enough to force the mother salt adjacent to the original "parent" diapir to migrate away from it and form a new salt mass some distance away. With continued addition of mother salt, this new salt mass eventually becomes a diapir; in essence, a second generation of salt structures develops. This process is repeated again and again with ever-younger generations of diapirs forming away from the parental diapir until the mother bed of salt is depleted.

The cause of the initial movement of the salt is uncertain. It may be an inhomogeneity in the roof of the salt layer, a gentle warp in the basement rocks, or a tectonic impulse (Trusheim, 1960, p. 1523-1524; Sannemann, 1968, p. 268). In Trusheim's interpretation, autonomous, isostatic movement of the salt is the fundamental reason the salt diapirs developed.

In a series of uniformly oriented, subparallel salt diapirs, then, the oldest is the central "parental" one. On each side, a second generation of daughter diapirs flanks this parental diapir; beyond these the succeeding diapirs represent ever-younger generations with the outermost diapirs being the youngest.

This age sequence, however, is not apparent in central Utah. The oldest beds deformed (tilted vertically or overturned) as part of the westernmost diapiric fold (the Sevier Bridge Reservoir diaipiric fold (fig. 16, 4)) are conglomerate beds of the Indianola Group. Correlative beds of the Indianola Group have been tilted vertically or overturned in a central diapiric fold (the Sanpete-Sevier Valley diapiric fold (fig. 16, 1)) as well as in the easternmost diapiric fold exposed (Little Clear Creek diapiric fold (fig. 16, 9). Apparently, all the diapiric folds, no matter what their position in the diapiric cluster, were formed at the same time.

The stratigraphic sequence at several localities indicates that the area has been deformed during at least three distinct diapiric episodes. And in each of these widely separated localities, the geologic evidence suggests that each of the three episodes began and seemingly ended at the same time. There is no evidence of progressive change of age from one diapir to another during any one of the three episodes.

Moreover, the repetition of extremely localized angular unconformities, exposed in single outcrops at different localities, suggests repeated reactivation and destruction of ever-younger diapiric folds, which always occupied the same structural zones and had the same trends. As each reactivated salt diapir welled upward (seemingly using the same conduit as the previous diapir), a new diapiric fold was formed, at the same site and along the same trend as the previous fold. Each time the newly emplaced salt was removed, the newly formed fold collapsed. If, as suggested by the halokinetic hypothesis, the salt diapirs continuously form away from the parental diapir, it 
is difficult to see how this central Utah pattern of diapiric folds being formed repeatedly and simultaneously in all localities can be explained solely by halo-kinesis. Some other factor, or factors, must be involved.

Although the central Utah salt diapirs may have been formed in part by halo-kinesis, I believe that tectonic forces are probably responsible for their development, and propose, therefore, that halotectonism (another term proposed by Trusheim (1957) to imply development of salt diapirs in response to tectonic forces) is a more plausible explanation.

The diapiric folds are elongate, narrow, faintly sinuous features that extend for many kilometers. This linearity suggests some form of structural control that determined not only the trends of the folds but also their distribution. The linearity of the folds plus the fact that they grew and collapsed repeatedly along the same axes suggests that well-established fault planes may have served as conduits for the salt and intermixed mudstones as they repeatedly welled upward toward the surface. This concept is supported by the fact that two of the diapiric folds align with major fault zones, and a third parallels such a zone (fig. 65). The Sanpete-Sevier Valley diapiric fold is collinear with the northeastward projection of the Sevier fault zone, and the Redmond fold aligns with the southward projection of the Wasatch fault zone. The Levan fold, which may be a northern segment of the Redmond fold, parallels the south end of the Wasatch fault zone.

The Sevier fault zone extends northeastward from southwestern Utah into central Utah. Southeast of Richfield (I-1) it appears as a series of small scarps that break surficial deposits along the east side of Sevier Valley. The scarps end near Richfield; northeastward beyond Richfield neither scarplets nor other features suggestive of the fault zone can be found. Even as the fault zone apparently ends, the elongate, narrow welt of Arapien mudstone beds, which marks the core of the Sanpete-Sevier Valley diapiric fold, begins and extends northeastward along the east side of Sevier Valley. The trend of the fault zone and the core of the fold are collinear.

A similar alignment appears to exist between the trend of the Wasatch fault zone and the Redmond diapiric fold. The Wasatch fault zone can be traced southward from northern Utah into this area as a series of small scarps that break surficial deposits. The zone ends near Fayette (F-3) (Cluff, Brogan, and Glass, 1973), but about $6 \mathrm{~km}$ (4 mi) farther south, near Gunnison (F-3), a line of Arapien Shale outcrops - the core of the Redmond diapiric fold-begins and extends southward along the west valley wall of
Sevier Valley to Redmond (G-3). Here, too, even as the fault zone ends, the line of Arapien Shale outcrops begins and is collinear with the trend of the fault zone.

Finally, from Nephi (B-3) southward, the Wasatch fault zone, marked by a series of small scarps, closely parallels the northward-trending welt of Arapien mudstone that crops out along the west flank of the Gunnison Plateau (fig. 65), and that I consider to be the core of the Levan diapiric fold.

Possibly this collinearity between major fault zones and diapiric folds is fortuitous, but I do not think so. I believe the alignment is meaningful and propose that the position and extent of each parental diapiric fold was originally determined by a preexisting, deepseated, fundamental structure. Other workers have commented on this apparent structural control of salt-generated structures. So, Stokes (1948, p. 14), discussing the salt structures in the Paradox Basin, noted: "This regional uniformity of trend is evidently

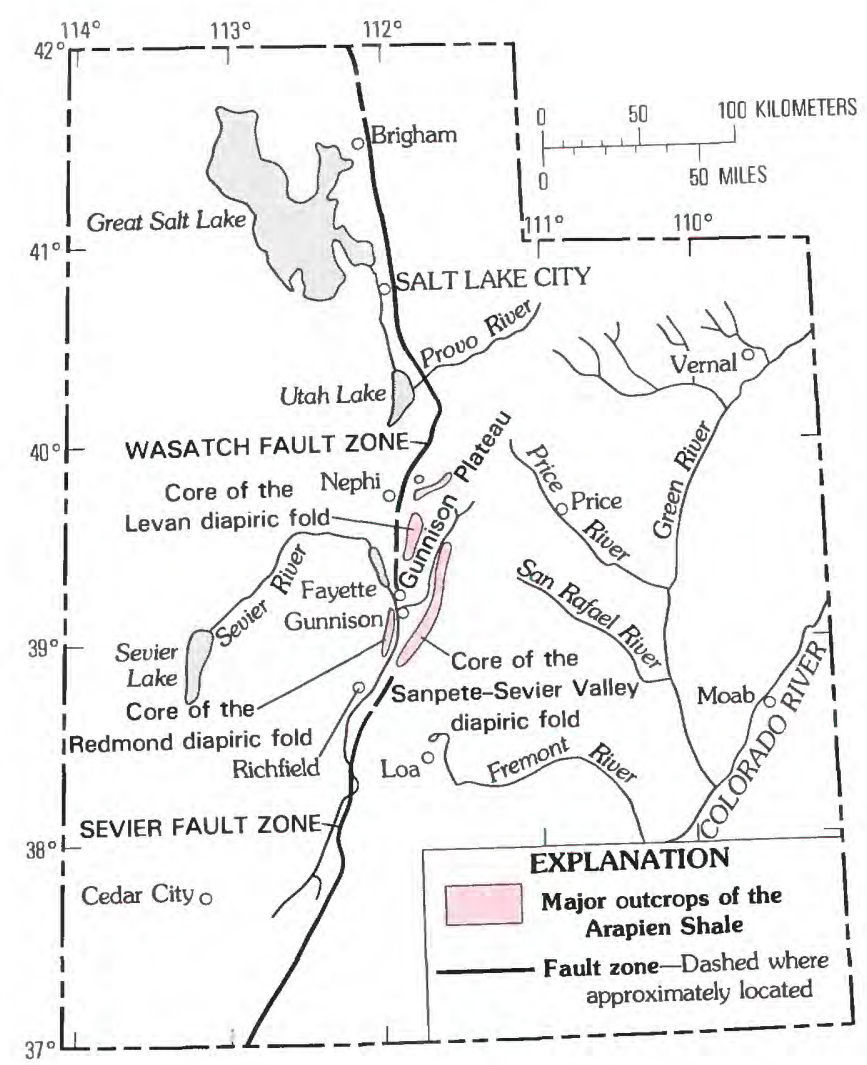

FiguRe 65.-Alignment of several diapiric cores with major fault zones in central Utah. The core of the Sanpete-Sevier Valley diapiric fold begins where the Sevier fault zone ends and extends northeastward, collinear with the fault zone. In much the same fashion, the core of the Redmond diapiric fold begins where the Wasatch fault zone ends, near Fayette, and continues the southward trend. 
a reflection of important deep-seated breaks in the basement rocks* **." Cater (1955, p. 125), also impressed by the regularity of distribution of the salt-cored anticlines in the Paradox Basin, similarly speculated that deep-seated structures were responsible for their parallelism. Cater and Elston (1963), on the basis of well data from the Paradox Basin, proposed that the larger diapirs were underlain by major pre-salt breaks. Baars and Stevenson (1981, p. 28) noted that past and recent seismic surveys in the Paradox Basin area "have left no doubt as to the existence of pre-salt faulting* **," which dictated the trend of the salt structures. Perthuisot (1981, p. 233), discussing the elongate salt diapirs of northern Tunisia, called upon deep movement of large basement blocks as an explanation for the preferred orientation of the diapirs. And Trusheim (1960, p. 1524) noted that the pattern of the northern German salt structures may reflect "a network of faults in the presaline basement."

I suggest that in central Utah such basic deepseated structures have continued to control and localize the younger reactivated versions of the diapiric folds. This would explain why these younger folds occupy the same sites and have the same trends as the older folds. Possibly each occurrence of crustal disturbance caused movement on one or more faults. Repeated movements along these faults have persisted at least from late Mesozoic time to the late Tertiary-Quaternary; each major movement has resulted in a major diapiric episode.

It may be that the salt, under confining pressure as a result of static load, finds relief when movement along a fault opens a passageway. The salt, using the fault plane as a conduit, flows upward to form a long, near-linear salt diapir. In its upward movement the salt pushes up the overlying mudstones and shaly siltstones of the Arapien Shale and these, in turn, intrude and bow up the overlying sedimentary rocks. The end result is a faintly sinuous, near-linear, fanshaped diapiric fold whose general trend, determined by the core of salt, reflects the fault plane now obliterated by the transported mudstones and siltstones. Repeated reactivation of the same fault results in repeated renewal of the same causative salt diapir. This would explain the near-linear shape of the major folds, the collinearity between known fault zones and several of these major folds, and the fact that similar folds have formed repeatedly in the same sites and with the same trends during all three major diapiric episodes.

I suggest, therefore, that each of the major diapiric folds marks the position of a zone of weakness-a preexisting fundamental fault-that may have formed in Precambrian time and that has been intermittently active ever since. These faults represent major flaws in the Earth's crust. The fact that the hingeline (the east margin of the Cordilleran geosynclinal basin), the Jurassic Arapien basin in which the salt accumulated, the transition zone, and the zone of diapiric activity all, at one time or another, occupied the same geographic area must be more than mere coincidence. Movement along these fundamental faults during Paleozoic time led to the development of the hingeline, and, during much of Early and Middle Jurassic time, to the development and subsequent growth of the saline basin of deposition in which the Arapien Shale with its contained salt and other evaporites accumulated. The striking break between the Colorado Plateaus and Basin and Range provinces probably reflects such fault movement.

If this interpretation is valid, each intrusive stage of each of the three major diapiric episodes reflects reactivation of these deep-seated faults. As all the diapiric folds display a similar pattern of development-the postulated sequence of geologic events is the same for the Sanpete-Sevier Valley fold as it is for the Sevier Bridge Reservoir fold-movement probably occurred, more or less in concert, along all the faults in the area in response to the regional stresses applied.

Presumably these faults first moved at some time after the Middle Jurassic, and were then used as conduits by the salt and intermixed mudstones of the Arapien Shale, which effectively obliterated the conduits. Subsequent tectonic pulses, probably once during the Late Cretaceous (post-Indianola Grouppre-Price River Formation), again during the Paleocene (post-North Horn Formation-pre-Flagstaff Limestone), and still again during the late(?) Oligocene or Miocene (post-Goldens Ranch Formation and post-Moroni Formation), triggered renewed movement along these faults, resulting in reactivation of the salt diapirs; this renewed diapiric movement further masked any evidence of the former faults.

Prior to the Paleocene, compressive forces from the west presumably caused movement along the faults. During the Late Cretaceous an eastward-directed thrust fault (stemming from the Sevier orogeny) may have triggered movement along these deep-seated faults and thus given rise to a diapiric episode. This may also explain the early Paleocene movement of the diapirs. Any movement along the faults since the Paleocene, however, must stem from the episode of crustal extension that began probably during late(?) Oligocene and Miocene time and that has persisted to the present. 


\section{ECONOMIC IMPLICATIONS}

The combination of multiple episodes of salt intrusion and the resultant repeated upward movements of the Arapien Shale may have created a series of structural traps in which oil and gas could accumulate, and in which mineral-rich, possibly saline, solutions could deposit their mineral content.

\section{OIL AND GAS}

The likelihood of finding economic pools of oil is enhanced if an area contains source rocks, reservoir beds, and suitable structural and stratigraphic traps. These three required elements appear to exist in this part of central Utah, and all seemingly have been influenced or modified in one way or another by the recurrent episodes of diapirism.

\section{SOURCE BEDS}

At least three major stratigraphic units in the area are potential source rocks-the Mancos Shale of Late Cretaceous age, the Manning Canyon Shale of Pennsylvanian and Mississippian age, and the Arapien Shale of Middle Jurassic age.

\section{MANCOS SHALE}

The Mancos Shale is widely exposed along the east flank of the Wasatch Plateau, in Castle Valley (E-7) (between the Wasatch Plateau and the west flank of the San Rafael Swell), and in the barren lowlands that lie at the base of the curving mass of the Book Cliffs. The shale extends westward beneath the Wasatch Plateau and, although not exposed, underlies much of Sanpete Valley. Hale's proposal $(1972$, p. 33) that Mancos sediments were deposited in a Sanpete Valley embayment of a shallow epicontinental seaway seems valid, and recent drilling has begun to give some indication of the thickness and extent of Mancos beds beneath Sanpete Valley.

The Mancos forms a thick sequence in central Sanpete Valley, but it probably thins rapidly westward and southward; I suspect that it does not extend much farther west than a north-trending line through Wales (D-4) (along the east flank of the Gunnison Plateau), nor much farther south than Manti (E-4). Three exploratory test wells drilled in the central part of Sanpete Valley, near Moroni (D-4) (fig. 9), penetrated black marine sedimentary rocks of the Mancos Shale. Together the well data indicate that the Mancos thins rapidly westward. The easternmost test (fig. 9), Hanson Oil Corporation's well Moroni $\mathrm{AX}-1$ ( $\mathrm{SE} 1 \frac{1}{4} \mathrm{NW} 1 / 4$ sec. 14 , T. 15 S., R. 3 E.) penetrated about $2,135 \mathrm{~m}(7,000 \mathrm{ft})$ of Mancos strata. About 2.4 $\mathrm{km}\left(1 \frac{1 / 2}{\mathrm{mi}}\right)$ to the west the Tennessee Gas Transmission Company's J.W. Irons well No. 1 (C, SE $1 / 4 \mathrm{NE} 1 / 4$ sec. 16 , T. 15 S., R. 3 E.) penetrated only about 1,070 $\mathrm{m}(3,500 \mathrm{ft})$ of Mancos. The westernmost well, the Phillips Petroleum Company's well Price "N" (SE $1 / 4$ $\mathrm{SE} 1 / 4$ sec. 29 , T. $15 \mathrm{~S}$., R. 3 E.), penetrated only about $610 \mathrm{~m}(2,000 \mathrm{ft})$ of Mancos Shale. These data emphasize this westward shoaling of the Mancos sea.

The two westernmost wells also demonstrate the westward rise of the top of the Mancos. In the J.W. Irons well the Mancos top is at $6,268 \mathrm{ft}$, but in the next well to the west, the Phillips Price "N" well, the top is at $3,058 \mathrm{ft}$. Possibly this westward rise of the top of the Mancos may reflect the upward movement of the Sanpete-Sevier Valley salt diapir, which is west of the three wells and hugs the east flank of the Gunnison Plateau.

Witkind and Sprinkel (1982, p. 317) interpreted these well data to mean that the Mancos sea occupied much of the present site of Sanpete Valley and probably had its shoreline close to what is now the east flank of the Gunnison Plateau.

The Mancos penetrated by the test wells appears to be lithologically similar to its exposures to the east-a series of black marine and paludal shales and brown sandstones-seemingly an excellent source of hydrocarbons.

\section{MANNING CANYON SHALE}

The Manning Canyon Shale is a dark-gray to brownish-gray marine shale that contains interleaved lenses of brown quartzitic sandstone and bluish-gray limestone. It crops out in the Charleston-Nebo thrust plate; good exposures are east of Mona (B-3).

Although the Manning Canyon, like the Mancos, is rich in an oil-generative type of organic material, it may be an unsuitable source rock because it has been subjected to high temperatures and is thermally supermature. Poole, Claypool, and Fouch (1983), discussing episodes of petroleum generation in the northern Great Basin, indicated on their figure 5 that many of the Paleozoic rocks in central Utah have been subjected to temperatures of $300^{\circ} \mathrm{C}\left(571^{\circ} \mathrm{F}\right)$ or higher. Virtually all surface exposures of the Manning Canyon are included within the area of these elevated temperatures, which coincides, in general, with the extent of the Charleston-Nebo thrust plate.

On the east flank of the Lake Mountains, along the west side of Utah Lake, several quarries have been opened in the Manning Canyon, and several clay 
beds in the shale are quarried extensively for the manufacture of brick and other ceramic products. The high-temperature clay minerals pyrophyllite and rectorite are principal constituents in these Manning Canyon exposures (Hall and Schnabel, 1985), and their presence reemphasizes the possibility that the Manning Canyon Shale is too mature, at least in that specific locality, for consideration as a promising source rock.

\section{ARAPIEN SHALE}

The calcareous mudstones that make up the bulk of the evaporite-rich Arapien Shale may also be potential source rocks for oil. Many geologists have noted the close association between evaporites and petroleum. Halbouty (1967), for example, discussing the salt domes along the Gulf Coast, demonstrated that large amounts of petroleum are associated with these domes. Weeks (1961) listed a multitude of basins in which petroleum accumulations are closely related to evaporite deposits. Kirkland and Evans (1981) proposed a new explanation for this close relation. They suggested that although most organisms cannot survive high-saline (mesosaline) conditionscharacterized by brines in which the saline content ranges from 4 to 12 percent-some algae not only can exist under these circumstances but literally thrive. Vast amounts of such algae, for example, are found in present-day basins marked by such mesosaline conditions. Upon death, the algae sink into the deeper waters of the basin, where they are buried by fine sediments and preserved as fine-grained carbonates rich in organic matter. These carbonates are immature source rocks which, upon maturation, produce petroleum.

It seems probable that the calcareous mudstones that make up most of the Arapien Shale developed under such mesosaline conditions. Presumably, marine waters from an open sea flowed periodically into the broad and extensive land-locked saline Arapien basin, which overlay much of central Utah during Middle Jurassic time. Continued evaporation resulted in increased salinity of the brines, and in time mesosaline conditions prevailed. If large amounts of organic matter did flourish in the Arapien basin, much of that organic matter must have been preserved in the bottom sediments, implying that the Arapien Shale is a possible source rock. Regrettably for the hydrocarbon potential, total organic carbon in the Arapien is low (R.J. Coskey, Forest Oil Company, oral commun., 1982); despite this, probably the one factor that detracts from the Arapien as a promising source rock is its low maturation level (D.A. Sprinkel, Placid Oil Company, oral commun., 1983).

\section{RESERVOIR BEDS}

Of the various units suitable for the accumulation of oil and gas, the most promising would be those sandstone beds that make up the Ferron Sandstone Member of the Mancos Shale. The Ferron produces both hydrocarbon and carbon dioxide gas in the Clear Creek area to the east along the crest of the Wasatch Plateau (Walton, 1963). Comparable reservoir beds, however, could be any of the sandstone beds of the Emery Sandstone Member of the Mancos Shale. Likely, some of the units in the stratigraphic section may be good reservoir beds because they are highly fractured and not because of any inherent primary porosity.

\section{POTENTIAL TRAPS}

The stratigraphic column in this sector of central Utah can be visualized as consisting of two parts: the salt-bearing and younger beds, which extend from the base of the Arapien Shale to the surface, and the pre-salt beds, which include the Twin Creek Limestone and older strata. The salt-bearing and younger beds are locally intensely warped and form the many diapiric folds described in the previous sections of this Professional Paper. By contrast, the pre-salt units, although deformed, may not be as severely contorted as the overlying younger units. I believe that structural traps suitable for the accumulation of commercial amounts of oil and gas are in both sequences of rocks.

\section{SALT-BEARING AND YOUNGER STRATA}

The upward thrust of the salt diapirs may have resulted in a series of structural traps, the most favorable of which would be those confined to areas underlain by the Mancos Shale. I recognize four types of traps related to the diapiric folds: (1) those that are along the flanks of a diapiric fold, (2) those that are along the crest of a fold, (3) those that are wholly within a diapiric fold, and (4) those that resulted from the collapse of a fold.

Traps along the flanks of the folds.-It seems probable that any diapirs formed beneath the Mancos Shale would have intruded and bowed up the Mancos. Such upwarped beds, juxtaposed against the intrusive Arapien mass, would seem to be ideal structural traps for the accumulation of oil and gas. 
The Arapien, in most localities a somewhat impervious mudstone, would serve as a barrier, trapping the oil and gas migrating up the upturned Mancos beds.

Traps along the crest of a fold.-A second type of potential trap may be those sedimentary beds that are draped across the crests of the diapiric folds. Examples are common in the Gulf Coast (Halbouty, 1967), but there, the draped, deformed beds directly overlie the salt core of the salt domes. In central Utah, the salt has pushed up the mudstones and shales of the Arapien Shale and these, in turn, have bowed up the overlying sedimentary beds. I consider these domed sedimentary beds likely targets. Although they have been extensively eroded and almost completely removed from the crests of many of the major diapiric folds, in several places, the crests of some of the larger folds (such as the north end of the Sanpete-Sevier Valley fold) are still mantled by surficial deposits. Suitable targets may underlie these surficial deposits.

Traps wholly within a diapiric fold.-Other potential oil traps may be wholly within a diapiric fold. The salt core of the diapir penetrated by the Argonaut-Federal well consisted almost completely of salt; little or no anhydrite was found. By contrast, various oil tests in this part of central Utah have drilled through an alternating sequence of salt and anhydrite. If the anhydrite beds in a diapiric fold were much fractured as a result of the repeated growth and collapse of that fold, they would have become quite porous. The salt, however, being more plastic and mobile, would retain its nonporous character. The result would be porous zones of anhydrite sealed by nonporous salt.

Traps resulting from collapse of a diapiric fold.Other structural traps may have formed as a consequence of the collapse of the diapiric folds. Although it is clear that some of the folds collapsed by gradual subsidence, much as shown in figure $60 \mathrm{~B}$, others appear to have collapsed along high-angle faults (fig. 60A). These latter folds are ones that may be worthy of investigation, for the downthrown limbs, either overturned or right-side-up (as, for example, in the ancestral Willow Creek (G-3) area, fig. 27), are probably sealed against the marginal faults, and thus become suitable traps for the accumulation of oil and gas. An inherent uncertainty in this type of trap, however, is how much the downthrown limb was fragmented. The limb was probably dropped thousands of meters, and most likely this occurred as many small spasmodic events; each event may have fractured and offset the once-continuous beds. Although the offset during each event may have been minor, the cumulative effect of many such offsets may be sizeable.

Previously, I have suggested that the zero line of the Mancos Shale is approximately along a northtrending line through Wales (D-4)-essentially along the east flank of the Gunnison Plateau-and that the Mancos thickens eastward (p. 132). In my view, then, those diapiric folds that are east of the Gunnison Plateau are the most favorable; they underlie the Mancos Shale, a good source rock, which also contains adequate reservoir rocks. By contrast, those folds west of the plateau are probably somewhat less favorable; they are distant from suitable source rocks.

\section{PRE-SALT STRATA}

Although the most feasible oil traps appear to be related in one way or another to the salt diapirs, other traps, concealed beneath the masking blanket of diapirically folded rocks, may have formed in the older pre-salt-bearing strata. Such traps seemingly would be unrelated to the diapiric deformation, which is confined to the salt-bearing and younger strata.

\section{OVERTHRUST BELT AND SALT DIAPIRS}

Salt diapirism may have had a profound effect on the position of oil pools, for whatever oil pools did form may have been displaced as a result of intrusion by the Arapien Shale. Much of the search for oil has centered on the overthrust belt, and overturned folds have been prime targets. In this sector of central Utah, for example, an overturned fold (possibly a remnant of the Charleston-Nebo thrust plate) well exposed along the west flank of the Gunnison Plateau in Chicken (D-2) and Pigeon (C-3) Creeks (east of Levan), was tested by Standard Oil of California's Levan Unit 1 (fig. 9) and by American Quasar's Chicken Creek Fed. No. 16-34. Ample evidence, however, demonstrates that the fold, after it was emplaced, was deformed and intruded by both gypsum beds and mudstones of the Arapien Shale (figs. 33, 34).

It seems clear that diapirism, throughout central Utah, has modified the thrust-related features. In the Gardner Canyon-Red Canyon (B-3) area, for example, the Arapien Shale broke, raised, and locally tilted the overturned fold that forms the upper plate of the Charleston-Nebo thrust (fig. 35). In the Thistle area, a northeast segment of the same overturned fold, plus its overlying mantle of Cretaceous and Tertiary units, has been arched to form an elongate north-trending upwarp (fig. 44). The causative agent appears to have 
been the Arapien Shale. If oil pools did form in overturned strata in this part of central Utah, they have probably been displaced during one or more episodes of salt diapirism. In essence, displacement of an oil pool may be a simple migration because of secondary deformation imposed on the original overturned fold.

\section{MINERAL DEPOSITS}

Base-metal deposits appear to be localized chiefly along the contact between the Arapien Shale and the country rock. For example, in the ancestral Willow Creek (G-3) area, a small mine known as the "Redmond silver mine" produced zinc ore intermittently from the time of World War I until about 1950, when it was closed owing to lack of ore. The mine, about 5 $\mathrm{km}$ ( $3 \mathrm{mi}$ ) east of Redmond (G-3), is in a small cuesta that occupies parts of secs. 4 and 5 , T. $21 \mathrm{~S}$., R. 1 E., Sevier County, Utah. The bulk of the oxidized zinc ore (chiefly hydrozincite and smithsonite) is concentrated in shattered Green River rocks next to a narrow "fault zone" (Heyl, 1963, 1978) that follows the contact between Arapien Shale on the east and the Green River Formation to the west.

The geologic relations near the mine (Witkind, 1981) can be interpreted in two ways: as a fault zone in which the block west of the fault has been downthrown, or as an intrusive contact between the Arapien Shale and the bowed-up Green River Formation (fig. 66). Although Heyl (1963, 1978), who examined the mine when it was open, favored the fault interpretation, I favor the second alternative because the Arapien Shale and Green River Formation relations here are identical to intrusive relations between these two units elsewhere in the area.

The source of the mineral-rich solutions is uncertain. They may stem from a volcanic center in the East Tintic Mountains, essentially the site of the East Tintic Mining District. Morris and Lovering (1979, p. 68-69) and Laughlin and others (1969) noted a significant igneous episode in that area during the Miocene. Still another possibility is that Arapien saline brines may have furnished the zinc and lead minerals. Thus, the Arapien Shale may be the ultimate source of these ore deposits. Whatever their source, these mineral-rich solutions were then deposited in the fractured rocks of the Green River Formation.

\section{SUMMARY}

Multiple episodes of salt diapirism seem the most reasonable explanation for the intense, localized deformation that marks the disturbed zone between the Colorado Plateaus and Basin and Range provinces in central Utah. The salt (halite), as well as other evaporites such as gypsum and anhydrite, is in the Arapien Shale of Middle Jurassic age. The salt, in large amounts and much of it now probably in the form of narrow, steep-walled diapirs, welled upward repeatedly, and in so doing forced the calcareous mudstones and gypsiferous shaly siltstones of the Arapien Shale to intrude, arch, and fold back the overlying sedimentary beds. The Arapien, thus, is best visualized as an intrusive sedimentary unit. Repeatedly forced upward by the reactivated salt diapirs, the soft and mobile Arapien mudstones have acted much like a viscous magma. Perhaps the best analogy is that of a hydraulic car jack. The salt represents the hydraulic fluid, the Arapien mudstones and shales, the bearing platform of the jack, and the uplifted younger strata, the car.

Upward movement of the concealed, elongate salt diapirs formed a series of generally north trending, subparallel diapiric folds, fan-shaped in cross section. Removal of the salt either by dissolution or extrusion resulted in failure of these folds. The general structural pattern, thus, resulted from the repeated growth and collapse of salt diapirs and those folds formed over them. Each time the salt diapirs reactivated, the newly formed folds occupied the same sites and followed the same trends as the earlier folds. The many signs of tectonic unrest-angular unconformities, steeply tilted to overturned beds-emanate from this recurrent growth and collapse of the reactivated salt diapirs and their overlying folds.

As a result of these recurrent disturbances, the Arapien has different "ages." Its depositional age is Middle Jurassic; its emplacement ages-the geologic age of movements-however, have changed repeatedly. In places, the Arapien deforms Cretaceous beds, elsewhere Eocene or Oligocene beds, and in several places it probably has deformed Pliocene or Quaternary beds. If one considers the age of the Arapien Shale to be solely Middle Jurassic, critical structural and economic relations are masked.

The contact relations between the Arapien Shale and the overlying beds are neither unconformities nor strip-thrusts, but rather intrusive contacts. I question whether the Arapien Shale is undisturbed anywhere in central Utah. The Arapien mudstones have been pushed about so many times by the contained salt that it seems unlikely that their present attitudes in any way reflect the attitudes of the sedimentary units that underlie them.

This recurrent movement of the salt emphasizes the critical fact that the stratigraphic section is divisible 

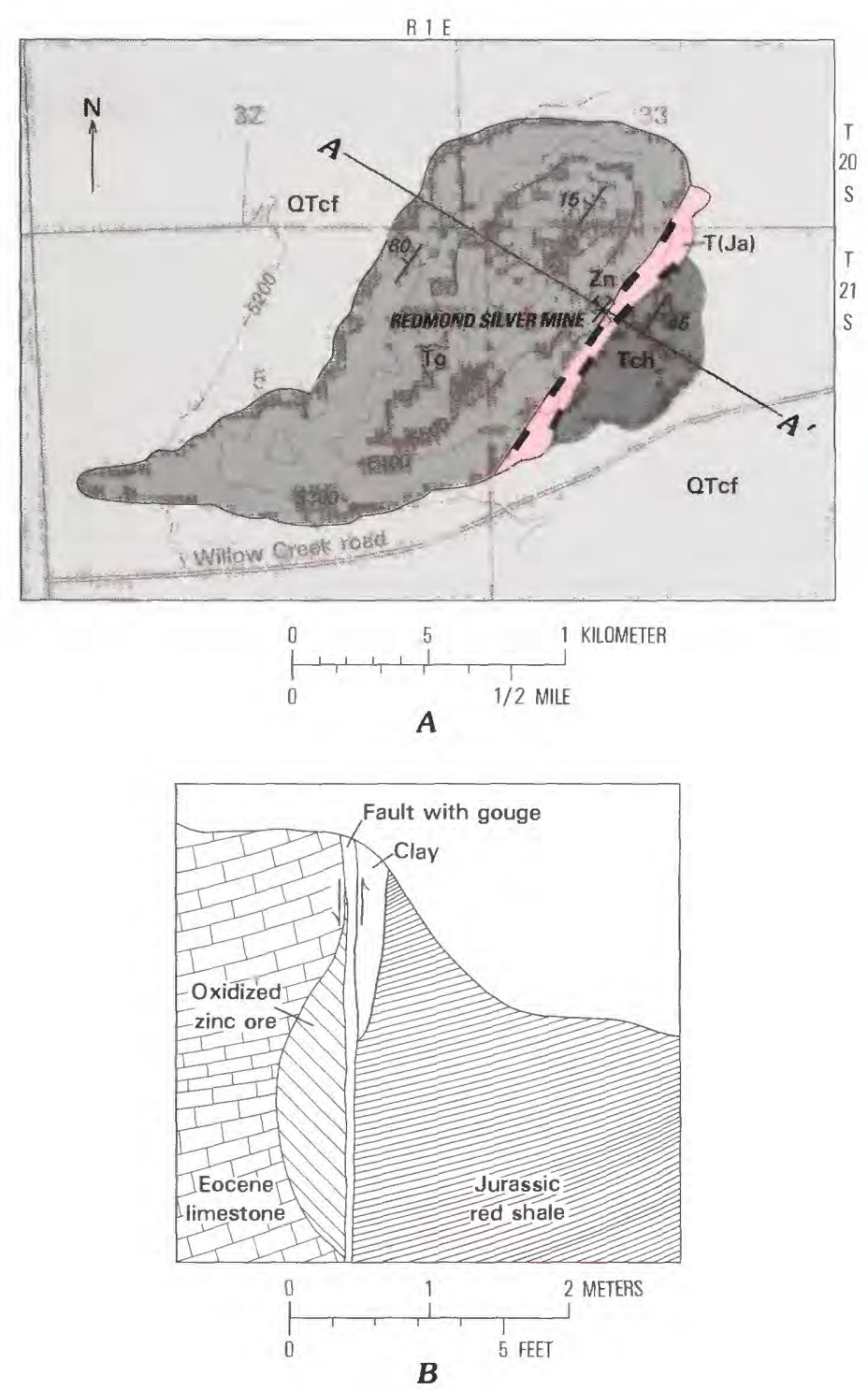

FIGURE 66.-Two alternative interpretations of the geologic relations near the abandoned zinc-producing "Redmond silver mine," secs. 4 and 5, T. 21 S., R. 1 E., Sevier County, Utah. Base modified from U.S. Geological Survey 1:24,000 Redmond (1966). Contour interval $100 \mathrm{ft}$. A, Mine is in a small, isolated cuesta about $5 \mathrm{~km}(3$ mi) east of Redmond. Geologic relations are from Witkind (1981). $B$, One interpretation suggests that the Green River Formation ("Eocene limestone") is downthrown against the Arapien Shale ("Jurassic red shale") along a normal fault. The ore is localized

into two parts - an upper part consisting of the saltbearing and younger strata, and an underlying, lower part consisting of the pre-salt older units. The intense localized deformation so visible on the surface is confined solely to the salt-bearing and younger units. The underlying pre-salt units, although deformed, have not been deformed as a result of the repeated salt movements.
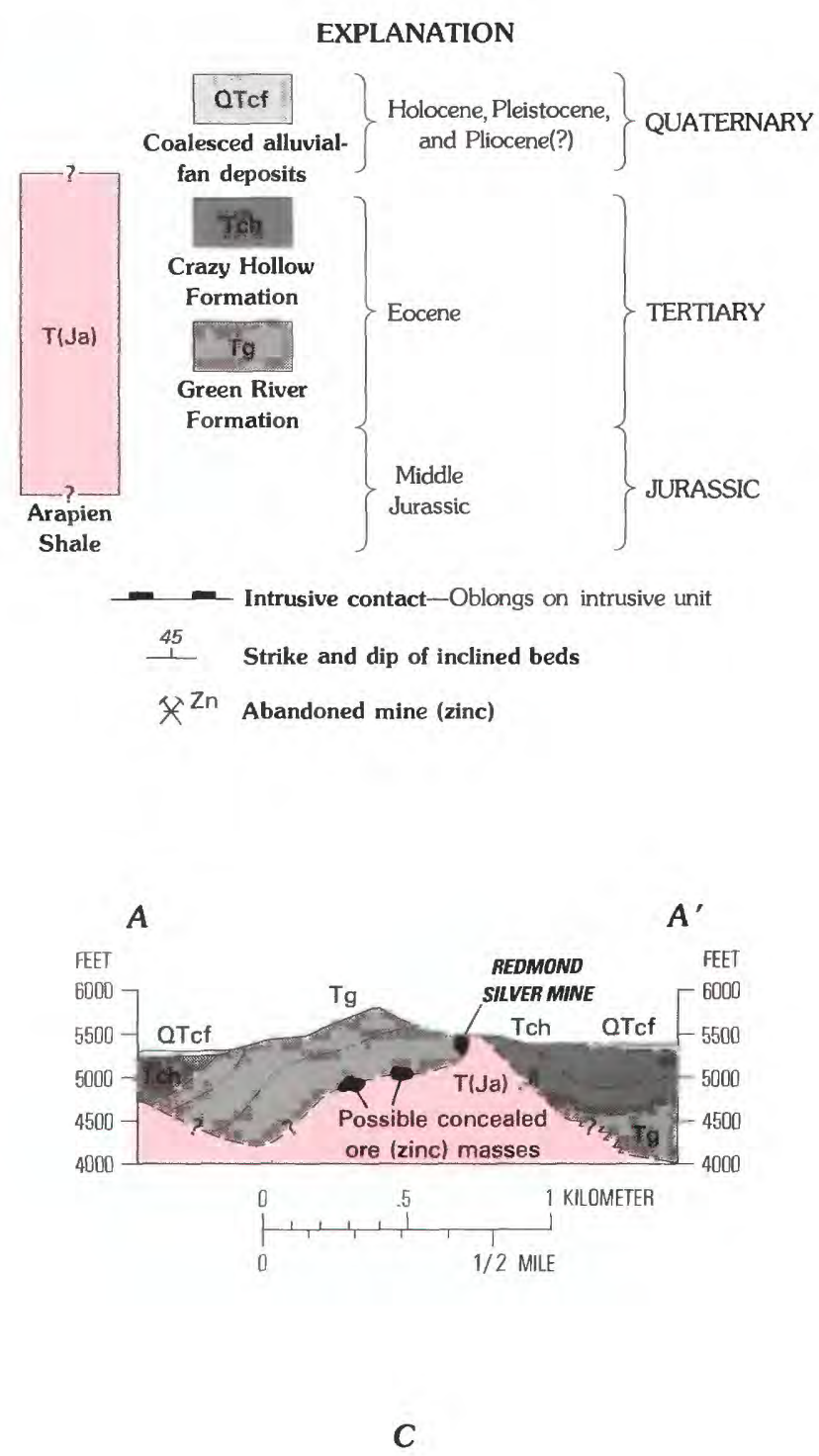

in the Green River adjacent to the fault. Illustration from Heyl (1963, 1978). Barbs show direction of relative fault movement. $C$, An alternative interpretation, which $\mathbf{I}$ favor, is that the area was deformed in the late(?) Oligocene by the intrusive action of the Arapien Shale. At this time, mineral-rich saline solutions moved up a brecciated zone formed along the intrusive contact between the Green River and the Arapien Shale and deposited their basemetal content along that contact. Bedding dashed within units; contacts dashed and queried to indicate uncertainty.

Sequences of sedimentary formations thin toward the crests of the diapiric folds, and discrete units within these sequences either pinch out against the flanks of the folds or are anomalously thin across the crests of the folds. This depositional thinning of sequences of units suggests that the salt diapirs welled upward very slowly but continuously, and in so doing have acted like dynamic barriers, impeding 
deposition. All units, from the Twist Gulch Formation of Middle Jurassic age up to and including the Green River Formation of Eocene age, display this depositional thinning. I believe that even younger units thin toward the diapiric crests, but because of inadequate exposures, I currently lack evidence to demonstrate this. Probably, these salt diapirs are rising today at a slow, almost imperceptible rate. Rapid upward surges of the salt diapirs sporadically interrupted this persistent upward movement. Each surge marked the beginning - the intrusive stage - of a new diapiric episode. Once the surge ended, the slow, continuous rise of the diapirs resumed.

The growth and collapse of a diapiric fold occur in three interrelated stages that together make up a diapiric episode: An intrusive stage, during which a salt diapir surges upward rapidly and forcibly drives up the overlying mudstones of the Arapien Shale, which in turn push up and fold back the overlying strata to form a diapiric fold, fan-shaped in cross section; an erosional stage, during which the diapiric fold fails (presumably as a result of partial removal of the salt) and its remnants are then eroded to an almost featureless plain; and a depositional stage, during which younger sediments are deposited on the newly formed erosional surface. This depositional stage is ended by a renewed upward surge of the salt diapir-the intrusive stage of the next younger diapiric episode.

I recognize at least three major diapiric episodes:

1. A Late Cretaceous to early Paleocene episode. The first clearly recognized diapiric episode probably began during the Late Cretaceous, after deposition of the Indianola Group, and ended in the early Paleocene after deposition of the North Horn Formation but before deposition of the Flagstaff Limestone.

2. An early Paleocene to late(?) Oligocene episode. The second episode probably began in early Paleocene time, after deposition of the North Horn Formation, and ended after the Eocene (possibly during the late Oligocene or Miocene) after deposition of the Goldens Ranch and Moroni Formations (of late Eocene to middle Oligocene age).

3. A late(?) Oligocene to Pliocene(?) episode. The third episode probably began during the late Oligocene or Miocene, after deposition of the Goldens Ranch and Moroni Formations, and may have ended during the Pliocene or Pleistocene. The evidence as to when this episode ended is inconclusive.

Some evidence suggests that a fourth, localized diapiric episode began and may have ended during the Pleistocene or Holocene.

The crests and flanks of many diapiric folds display a distinctive structural pattern that reflects the three episodes of salt diapirism. In its simplest form this pattern consists of vertical to overturned beds of the Indianola Group at the base of an exposure. These upturned Indianola beds are unconformably overlain by a sequence of gently to moderately inclined Price River and North Horn strata. The Price River and North Horn Formations, in turn, are unconformably overlain by a stack of downwarped Tertiary beds, consisting chiefly of the Flagstaff, Colton, and.Green River Formations. During the first diapiric episode the Indianola beds were pushed up to vertical or overturned attitudes. During the second episode the Price River and North Horn sequence also was bowed up, but in most places not as drastically as the Indianola beds. The crest of the upwarp formed during this second episode coincides, more or less, with the crest of the previous upwarp. During the third episode the Flagstaff and younger Tertiary beds were deformed. Locally, these younger Tertiary strata have been bowed up to vertical attitudes, but in most places they are warped down and define the great monoclines that mark the Sanpete-Sevier Valley area. The general geologic pattern is best expressed by the phrase: Upturned Cretaceous and Jurassic strata overlain by downturned Tertiary beds. (See also p. 8.)

Two major angular unconformities, thus, are exposed in single outcrops-one between the Indianola and the overlying Price River and North Horn sequence, and a second between the Price River and North Horn sequence and the overlying Flagstaff Limestone. These angular unconformities represent the periods of erosion during which the upturned, deformed beds were beveled to surfaces of low relief. As the strata above and below these angular unconformities are traced laterally, away from the folds, they gradually lessen in dip, and in distances as short as $0.8 \mathrm{~km}(1 / 2 \mathrm{mi})$ are conformable.

Most likely, if exposures were adequate, the same structural pattern would be found in all the diapiric folds. The repetition of this pattern-it has been found in the western, central, and eastern sectors of the area-suggests that during each of the three major diapiric episodes all the salt diapirs in the area were reactivated more or less concurrently. This implies that the causative forces were regional in extent.

Although all the salt diapirs apparently acted more or less in unison during each of the three major diapiric episodes, some evidence suggests that during the late Tertiary or Quaternary, small cells of these larger salt diapirs reactivated independently and deformed parts of the previously formed diapiric folds. The Red Knolls (p. 30), west of Redmond, are 
composed of the Arapien Shale and form topographic prominences that rise above more durable units. These knolls of the easily eroded Arapien must have been pushed up in the recent geologic past or they would have long since been eroded.

Overturned folds, part of the Charleston-Nebo thrust plate, were intruded, broken, tilted, and probably arched by the intrusive action of the Arapien Shale. The field evidence suggests that the Charleston-Nebo thrust plate was emplaced at some time after Middle Jurassic (Bathonian) time but before Late Cretaceous (Maastrichtian) time. Farther north, south of the Uinta Mountains, Bryant and Nichols (1988, p. 420) concluded, based on stratigraphic evidence, "****that major movement on the Charleston thrust occurred in Campanian time***."

Erosion partly destroyed the thrust plate during its eastward movement. Subsequently, the deeply eroded plate was buried beneath near-horizontal younger Cretaceous and Tertiary rocks. Later, salt diapirs, overridden and concealed beneath the thrust plate, welled upward and arched the thrust plate and its overlying mantle of Cretaceous and Tertiary sedimentary rocks. Since then, erosion has removed many of these younger sedimentary rocks, leaving their tilted remnants as a reflection of the former arched sedimentary cover.

Whatever oil pools formed in these overturned beds of the Charleston-Nebo thrust plate possibly were displaced or dissipated as a result of this diapiric activity.

The salt diapirs, and the diapiric folds formed over them, may be structurally controlled. The folds are elongate, faintly sinuous, northward-trending upwarps that parallel the major fault systems in the area. Two of the largest diapiric folds are collinear with major fault zones. Possibly, renewed movement along preexisting faults reactivated the salt diapirs, which then forced the Arapien mudstones and shales into the fault planes. These planes acted as conduits along which the mudstone moved upward toward the surface; in time, the rising mudstone effectively obliterated the fault planes. In this interpretation, the former trace of a fault plane is now expressed as a northward-trending, slightly sinuous belt of Arapien mudstone-the core of a diapiric fold.

The forces responsible for the movement of the salt are unknown; important factors were probably buoyancy, static load, regional lateral compression, crustal extension, or some combination of these. The slow but persistent upwelling of the salt diapirs possibly reflects sedimentary loading in those areas adjacent to the diapirs. By contrast, the rapid upward surges of the salt diapirs may have been in response to fault movement that was triggered, during pre-Paleocene time, by pulses of compression (thrust faulting) from the west, and during post-Paleocene time, by crustal extension. Static load was important, for it kept the salt under compression; the reactivated faults merely offered avenues of escape for the tightly confined, mobile salt.

The emplacement of the salt diapirs and the resultant upward bowing of the intruded rocks may have created structural traps between the diapirs and the country rock in which oil and gas could accumulate. The most promising sites for such traps would be where the diapirs deformed the Mancos Shale.

Base-metal deposits, probably deposited from mineral-rich, possibly saline solutions, may be concentrated along parts of the contact between the country rock and the intrusive mudstones of the Arapien Shale.

\section{REFERENCES CITED}

Armstrong, R.L., 1968, Sevier orogenic belt in Nevada and Utah: Geological Society of America Bulletin, v. 79, p. 429-458.

Atwater, G.I., and Forman, M.J., 1959, Nature and growth of southern Louisiana salt domes and its effect on petroleum accumulation: American Association of Petroleum Geologists Bulletin, v. 43, no. 11, p. 2592-2622.

Baars, D.L., and Stevenson, G.M., 1981, Tectonic evolution of the Paradox Basin, Utah and Colorado, in Geology of the Paradox Basin: Rocky Mountain Association of Geologists Guidebook, 1981 Field Conference, p. 23-31.

Baer, J.L., 1976, Structural evolution of central Utah-Late Permian to Recent, in Geology of Cordilleran hingeline: Rocky Mountain Association of Geologists Guidebook, 27th Annual Field Conference, 1976, p. 37-45.

Baker, A.A., 1976, Geologic map of the west half of the Strawberry Valley quadrangle, Utah: U.S. Geological Survey Miscellaneous Investigations Series Map I-931.

Banks, R.L., 1986, The geology of the Fountain Green North quadrangle, Sanpete and Juab Counties, Utah: DeKalb, Ill., Northern Illinois University M.S. thesis, 246 p.

1988, Geology of the Fountain Green North quadrangle, Sanpete and Juab Counties, Utah: Utah Geological and Mineral Survey, Open-File report 126, $78 \mathrm{p}$.

Biek, R.F., 1988a, The geology of the Nephi $7.5^{\prime}$ quadrangle, central Utah: DeKalb, Ill., Northern Illinois University M.S. thesis, $576 \mathrm{p}$.

1988b, Geologic map of the Nephi quadrangle, Juab County, Utah: Utah Geological and Mineral Survey, Open-File report $148,95 \mathrm{p}$.

Billings, Marland, 1933, Thrusting younger rocks over older: American Journal of Science (Fifth series), v. 25, no. 146, p. 140-165.

Bissell, H.J., 1962, Pennsylvanian-Permian Oquirrh Basin of Utah: Brigham Young University Geology Studies, v. 9, pt. 1, p. $26-49$.

Black, B.A., 1965, Nebo overthrust, southern Wasatch Mountains, Utah: Brigham Young University Geology Studies, v. 12, p. 55-89. 
Brown, R.P., 1975, A regional gravity survey of the Sanpete-Sevier Valleys and adjacent areas in Utah: Salt Lake City, Utah, University of Utah M.S. thesis, 73 p.

Brown, R.P., and Cook, K.L., 1982, A regional gravity survey of the Sanpete-Sevier Valleys and adjacent areas in Utah, in Nielsen, D.L., ed., Overthrust belt of Utah Symposium: Utah Geological Association Publication 10, p. 121-135.

Bryant, Bruce, and Nichols, D.J., 1988, Late Mesozoic and early Tertiary reactivation of an ancient crustal boundary along the Uinta trend and its interaction with the Sevier orogenic trend, in Schmidt, C.J., and Perry, W.J., eds., Interaction of the Rocky Mountain foreland and the Cordilleran thrust belt: Geological Society of America Memoir 171, p. 411-430.

Campbell, J.A., 1979, Middle to Late Cenozoic stratigraphy and structural development of the Canyon Range, central Utah: Utah Geology, v. 6, p. 1-16.

Cater, F.W., Jr., 1955, The salt anticlines of southwestern Colorado and southeastern Utah, in Geology of parts of Paradox, Black Mesa, and San Juan Basins: Four Corners Geological Society Guidebook, p. 125-131.

Cater, F.W., Jr., and Elston, D.P., 1963, Structural development of salt anticlines of Colorado and Utah, in Childs, O.E., and Beebe, B.W., eds., Backbone of the Americas: Tulsa, Okla., American Association of Petroleum Geologists Memoir 2, p. 152-159.

Christiansen, F.W., 1952, Structure and stratigraphy of the Canyon Range, central Utah: Geological Society of America Bulletin, v. 63, p. 717-740.

-1963 , Oil and gas possibilities of the transition zone in central Utah, in Oil and gas possibilities of Utah, re-evaluated: Utah Geological and Mineral Survey Bulletin 54, p. 327-338.

Cluff, L.S., Brogan, G.E., and Glass, C.E., 1973, Earthquake fault investigation and evaluation-Wasatch fault, southern portion: Oakland, Calif., Woodward-Lundgren and Associates, 79 p. [Prepared for Utah Geological and Mineral Survey.]

Crittenden, M.D., Jr., 1961, Magnitude of thrust faulting limits in northern Utah: U.S. Geological Survey Professional Paper 424-D, p. D128-D131.

Crosby, G.W., 1959, Geology of the south Pavant Range, Millard and Sevier Counties, Utah: Brigham Young University Geology Studies, v. 6, no. 3,59 p.

Doelling, H.H., 1988, Geology of Salt Valley anticline and Arches National Park, Grand County, Utah: Utah Geological and Mineral Survey Bulletin 122, 58 p.

Duncan, J.M., Fleming, R.W., and Patton, F.D., 1986, Report of the Thistle Slide Committee to the State of Utah, Department of Natural Resources, Division of Water Rights: U.S. Geological Survey Open-File Report 86-505, 95 p.

Eardley, A.J., 1933a, Stratigraphy of the southern Wasatch Mountains, Utah: Michigan Academy of Science, Arts, and Letters, v. 18 , p. $307-344$

$-1933 \mathrm{~b}$, Structure and physiography of the southern Wasatch Mountains, Utah: Michigan Academy of Science, Arts, and Letters, v. 19 , p. $377-400$.

1969, Charting the Laramide structures of western Utah, in Guidebook of northern Utah: Utah Geological and Mineralogical Survey Bulletin 82, p. 51-70.

Fouch, T.D., Lawton, T.F., Nichols, D.J., Cashion, W.D., and Cobban, W.A., 1982, Chart showing preliminary correlation of major Albian to Middle Eocene rock units from the Sanpete Valley in central Utah to the Book Cliffs in eastern Utah, in Nielsen, D.L., ed., Overthrust belt of Utah Symposium: Utah Geological Association Publication 10, p. 267-272.
Foutz, D.R., 1960, Geology of the Wash Canyon area, southern Wasatch Mountains, Utah: Brigham Young University Geology Studies, v. 7, no. 2, 37 p.

Gilliland, W.N., 1948, Geology of the Gunnison quadrangle, Utah: Columbus, Ohio, Ohio State University Ph. D. thesis, 178 p. 1951, Geology of the Gunnison quadrangle, Utah: University of Nebraska Studies, no. 8.

1963, Sanpete-Sevier Valley anticline of central Utah: Geological Society of America Bulletin, v. 74, no. 2, p. 115-124.

Gundersen, W.C., and Gilliland, W.N., 1967, Stratigraphic reflections of the Sanpete-Sevier Valley anticline of central Utah: Transactions of the New York Academy of Sciences, Series II, v. 29 , no. 6 , p. $686-699$.

Halbouty, M.T., 1967, Salt domes, Gulf region, United States and Mexico: Houston, Texas, Gulf Publishing Company, 425 p.

Hale, L.A., 1972, Depositional history of the Ferron Formation, central Utah, in Basin and Range transition zone, central Utah: Utah Geological Association Publication 2, p. 29-40.

Hall, R.B., and Schnabel, Lorraine, 1985, Brick clay of the Manning Canyon Shale, in Clays and clay minerals, western Colorado and eastern and central Utah: 1985 International Clay Conference Field Trip Guidebook, p. 54-67.

Hansen, A.R., 1976, Jurassic salts of the hingeline area, southern Rocky Mountains, in Geology of the Cordilleran hingeline: Rocky Mountain Association of Geologists Guidebook, 27th Annual Field Conference, p. 261-266.

Hardy, C.T., 1949, Stratigraphy and structure of the Arapien Shale and the Twist Gulch Formation in Sevier Valley, Utah: Columbus, Ohio, Ohio State University Ph. D. thesis, 85 p.

1952, Eastern Sevier Valley, Sevier and Sanpete Counties, Utah: Utah Geological and Mineral Survey Bulletin 43, 98 p.

Hardy, C.T., and Zeller, H.D., 1953, Geology of the west-central part of the Gunnison Plateau, Utah: Geological Society of America Bulletin, v. 64, p. 1261-1278.

Harris, H.D., 1954, Geology of the Birdseye area, Thistle Creek Canyon, Utah: The Compass, v. 31, no. 3, p. 189-208.

Hawks, R.L., 1980, The stratigraphy and structure of the Cedar Hills, Sanpete County, Utah: Brigham Young University Geology Studies, v. 27, pt. 1, p. 67-80.

Heller, P.L., Bowdler, S.S., Chambers, H.P., Coogan, J.C., Hagen, E.S., Shuster, M.W., and Winslow, N.S., 1986, Time of initial thrusting in the Sevier orogenic belt, Idaho-Wyoming and Utah: Geology, v. 14, p. 388-391.

Heyl, A.V., 1963, Oxidized zinc deposits in the United States: U.S. Geological Survey Bulletin 1135-B, 104 p.

-1978, Redmond silver mine, Redmond District, Sevier County, Utah, in Guidebook to mineral deposits of southwestern Utah: Utah Geological Association Publication 7 (International Association on the genesis of ore deposits), p. 73-75.

Hintze, L.F., 1962, Precambrian and Lower Paleozoic rocks of north-central Utah: Brigham Young University Geology Studies, v. 9 , pt. 1, p. 8-16.

Hunt, R.E., 1950, Geology of the northern part of the Gunnison Plateau, Utah: Columbus, Ohio, Ohio State University Ph. D. thesis, $267 \mathrm{p}$

Imlay, R.W., 1967, Twin Creek Limestone (Jurassic) in the Western Interior of the United States: U.S. Geological Survey Professional Paper 540, $105 \mathrm{p}$.

1980, Jurassic paleobiogeography of the conterminous United States in its continental setting: U.S. Geological Survey Professional Paper 1062, $134 \mathrm{p}$.

Jackson, M.P.A., 1985, Natural strain in diapiric and glacial rock salt, with emphasis on Oakwood Dome, East Texas: Bureau of Economic Geology, University of Texas at Austin, Report of Investigations $143,74 \mathrm{p}$. 
Johnson, K.D., 1959, Structure and stratigraphy of the Mount Nebo-Salt Creek area, southern Wasatch Mountains, Utah: Provo, Utah, Brigham Young University M.S. thesis, 49 p.

Kaliser, B.N., and Fleming, R.W., 1986, The 1983 landslide dam at Thistle, Utah, in Schuster, R.L., ed., Landslide damsProcesses, risk, and mitigation: American Society of Civil Engineers, Geotechnical Special Publication 3, p. 59-83.

Khin, Maung-auna, 1956, The geology of the district north of Indianola, Utah County, Utah: Columbus, Ohio, Ohio State University M.S. thesis, $214 \mathrm{p}$.

Kirkland, D.W., and Evans, Robert, 1981, Source-rock potential of evaporitic environment: American Association of Petroleum Geologists Bulletin, v. 65, no. 2, p. 181-190.

Laughlin, A.W., Lovering, T.S., and Mauger, R.L., 1969, Age of some Tertiary igneous rocks from the East Tintic District, Utah: Economic Geology, v. 64, no. 8, p. 915-918.

Lautenschlager, H.K., 1952, The geology of the central part of the Pavant Range, Utah: Columbus, Ohio, Ohio State University Ph. D. thesis, $188 \mathrm{p}$.

Lawton, T.F., 1985, Style and timing of frontal structures, thrust belt, central Utah: American Association of Petroleum Geologists Bulletin, v. 69 , no. 7, p. 1145-1159.

LeVot, Michel, 1984, L'overthrust belt face aux Uinta Mountains (Utah, U.S.A.): Brest, France, University of Brest Ph. D. thesis, $278 \mathrm{p}$.

Lindsey, D.A., Glanzman, R.K., Naeser, C.W., and Nichols, D.J., 1981, Upper Oligocene evaporites in basin fill of the Sevier Desert region, western Utah: American Association of Petroleum Geologists Bulletin, v. 65, no. 2, p. 251-260.

Mattox, S.R., 1987, Provisional geologic map of the Hells Kitchen Canyon SE quadrangle, Sanpete County, Utah: Utah Geological and Mineral Survey Map 98.

Mattox, S.R., and Weiss, M.P., 1987, Reactivation of a Cretaceous thrust surface by Basin-and-Range extension, southwestern Gunnison Plateau, central Utah: The Mountain Geologist, v. 24 , no. 3 , p. 55-65.

McGookey, D.P., 1960, Early Tertiary stratigraphy of part of central Utah: American Association of Petroleum Geologists Bulletin, v. 44, no. 5, p. 589-615.

Merrill, R.C., 1972, Geology of the Mill Fork area, Utah: Brigham Young University Geology Studies, v. 19, pt. 1, p. 65-88.

Metter, R.E., 1955, The geology of part of the southern Wasatch Mountains, Utah: Columbus, Ohio, Ohio State University Ph. D. thesis, $244 \mathrm{p}$.

Mitchell, G.C., 1979, Stratigraphy and regional implications of the Argonaut Energy No. 1 Federal, Millard County, Utah: Rocky Mountain Association of Geologists-Utah Geological Association Guidebook, Basin and Range symposium and Great Basin Field Conference, p. 503-514.

Morris, H.T., 1983, Interrelations of thrust and transcurrent faults in the central Sevier orogenic belt near Leamington, Utah: Geological Society of America Memoir 157, p. 75-81.

Morris, H.T., and Lovering, T.S., 1979, General geology and mines of the East Tintic Mining District, Utah and Juab Counties, Utah: U.S. Geological Survey Professional Paper 1024, 203 p.

Moulton, F.C., 1975, Lower Mesozoic and Upper Paleozoic petroleum potential of the hingeline area, central Utah, in Deep drilling frontiers in the central Rocky Mountains, 1975: Rocky Mountain Association of Geologists Guidebook, p. 87-97.

Muessig, S.J., 1951, Geology of a part of Long Ridge, Utah: Columbus, Ohio, Ohio State University Ph. D. thesis, 213 p.

North American Commission on Stratigraphic Nomenclature, 1983, North American Stratigraphic Code: American Association of Petroleum Geologists Bulletin, v. 67, no. 5, p. 841-875.

Perthuisot, V., 1981, Diapirism in northern Tunisia: Journal of Structural Geology, v. 3, no. 3, p. 231-235.
Picard, M.D., 1980, Stratigraphy, petrography, and origin of evaporites, Jurassic Arapien Shale, central Utah: Utah Geological Association Publication 8, Henry Mountains Symposium, p. 129-150.

Pinnell, M.L., 1972, Geology of the Thistle quadrangle, Utah: Brigham Young University Geology Studies, v. 19, pt. 1, p. 89-130.

Poole, F.G., Claypool, G.E., and Fouch, T.D., 1983, Major episodes of petroleum generation in part of the northern Great Basin: Geothermal Resources Council, Special Report 13, p. 207-213.

Pratt, A.R., Heylmun, E.B., and Cohenour, R.E., 1966, Salt deposits of Sevier Valley, Utah: Second Symposium on Salt, Northern Ohio Geological Society, pt. 1, p. 48-58.

Rigby, J.K., and Clark, D.L., 1962, Devonian and Mississippian Systems in central Utah: Brigham Young University Geology Studies, v. 9, pt. 1, p. 17-25.

Ritzma, H.R., 1972, Six Utah "hingeline" wells, in Baer, J.L., and Callaghan, Eugene, eds., Basin and Range transition zone, central Utah: Utah Geological Association Publication 2, p. 75-80.

Runyon, D.M., 1977a, Collapsed diapiric structures and their potential economic significance, Indianola, Utah, in Rocky Mountain thrust belt geology and resources: Wyoming Geological Association Guidebook, 29th Annual Field Conference, p. $479-486$.

1977b, Structure, stratigraphy, and tectonic history of the Indianola quadrangle, central Utah: Brigham Young University Geology Studies, v. 24, pt. 2, p. 63-82.

Sannemann, D., 1968, Salt-stock families in northwestern Germany: American Association of Petroleum Geologists Memoir 8, p. 261-270.

Schoff, S.L., 1951, Geology of the Cedar Hills, Utah: Geological Society of America Bulletin, v. 62, p. 619-645.

Shoemaker, E.M., Case, J.E., and Elston, D.P., 1958, Salt anticlines of the Paradox Basin, in Guidebook to the geology of the Paradox Basin: Intermountain Association of Petroleum Geologists, 9th Annual Field Conference, p. 39-59.

Spieker, E.M., 1946, Late Mesozoic and early Cenozoic history of central Utah: U.S. Geological Survey Professional Paper 205-D, p. 117-161.

1949, The transition between the Colorado Plateaus and the Great Basin in central Utah: Utah Geological Society, Guidebook to the geology of Utah 4, $106 \mathrm{p}$.

Sprinkel, D.A., 1982, Twin Creek Limestone-Arapien Shale relations in central Utah, in Nielsen, D.L., ed., Overthrust belt of Utah Symposium: Utah Geological Association Publication 10, p. 169-179.

Sprinkel, D.A., and Waanders, G.L., 1984, Correlation of the Twin Creek Limestone with the Arapien Shale in the Arapien embayment, Utah-A preliminary appraisal [abs.]: American Association of Petroleum Geologists Bulletin, v. 68, no. 7, p. 950.

Sprinkel, D.A., Witkind, I.J., and Baer, J.L., 1982, Road logs prepared for the Field Conference of the Utah Geological Association, September 21, 22, and 23, 1981, in Nielsen, D.L., ed., Overthrust belt of Utah Symposium: Utah Geological Association Publication 10, p. 301-334.

Standlee, L.A., 1982, Structure and stratigraphy of Jurassic rocks in central Utah-Their influence on tectonic development of Cordilleran foreland thrust belt, in Geologic studies of the Cordilleran thrust belt: Rocky Mountain Association of Geologists Guidebook, v. 1, p. 357-382.

Stokes, W.L., 1948, Geology of the Utah-Colorado salt dome region, with emphasis on Gypsum Valley, Colorado: Utah Geological Society Guidebook to the Geology of Utah 3, $50 \mathrm{p}$. 
1952, Salt-generated structures of the Colorado Plateau and possible analogies [abs.]: American Association Petroleum Geologists Bulletin, v. 36 , no. 5, p. 961.

1956, Tectonics of Wasatch Plateau and near-by areas [abs.]: American Association Petroleum Geologists Bulletin, v. 40, no. 4 , p. 790 .

1982, Geologic comparisons and contrasts, Paradox and Arapien basins, in Nielsen, D.L., ed., Overthrust belt of Utah Symposium: Utah Geological Association Publication 10, p. 1-11.

Stokes, W.L., and Holmes, C.N., 1954, Jurassic rocks of southcentral Utah, in Geology of portions of the High Plateaus and adjacent Canyonlands, central and south-central Utah: Intermountain Association of Petroleum Geologists Guidebook, 5th Annual Field Conference, p. 34-41.

Stolle, J.M., 1978, Stratigraphy of the Lower Tertiary and Upper Cretaceous(?) continental strata in the Canyon Range, Juab County, Utah: Brigham Young University Geology Studies, v. 25 , pt. 3, p. 117-139.

Taylor, J.M., 1980, Geology of the Sterling quadrangle, Sanpete County, Utah: Brigham Young University Geology Studies, v. 27 , pt. 1, p. 117-135.

Trusheim, F., 1957, Uber halokinese and ihre bedeutung fur die strukturelle entwicklung Norddeutschlands: Zeitschrift der Deutschen Geologischen Gesellschaft, v. 109, p. 111-151.

-1960 , On the mechanism of salt migration in northern Germany: American Association of Petroleum Geologists Bulletin, v. 44 , no. 9 , p. 1519-1540.

Villien, Alain, 1984, Central Utah deformation belt: Boulder, Colo., University of Colorado $\mathrm{Ph}$. D. thesis, $283 \mathrm{p}$.

Villien, Alain, and Kligfield, R.M., 1986, Thrusting and synorogenic sedimentation in central Utah, in Peterson, J.A., ed., Paleotectonics and sedimentation: American Association of Petroleum Geologists Memoir 41, p. 281-307.

Waanders, G.L., and Sprinkel, D.A., 1984, Palynologic age and correlation of Twin Creek Limestone and Arapien Shale, southwest Wyoming and central Utah [abs.]: Palynology, v. 9, p. 257.

Walton, P.T., 1955, Wasatch Plateau gas fields, Utah: American Association of Petroleum Geologists Bulletin, v. 39, no. 4, p. $385-421$.

-1963, Gas fields of the Wasatch Plateau: Utah Geological and Mineral Survey Bulletin 54, p. 341-352.

Weeks, L.G., 1961, Origin, migration, and occurrence of petroleum, in Moody, G.B., ed., Petroleum exploration handbook: New York, McGraw-Hill, p. 5-1 to 5-50.

Weiss, M.P., 1982, Structural variety on the east front of the Gunnison Plateau, central Utah, in Nielsen, D.L., ed., Overthrust belt of Utah Symposium: Utah Geological Association Publication 10 , p. $49-63$.

Willis, G.C., 1986, Geologic map of the Salina quadrangle, Sevier County, Utah: Utah Geological and Mineral Survey Map 83.

1987, Investigation of potential geologic hazards near the Thistle Landslide, Utah County, Utah: Utah Geological and Mineral Survey Report of Investigation 213, 24 p.
Witkind, I.J., 1981, Reconnaissance geologic map of the Redmond quadrangle, Sanpete and Sevier Counties, Utah: U.S. Geological Survey Miscellaneous Investigations Map I-1304-A.

1982, Salt diapirism in central Utah, in Nielsen, D.L., ed., Overthrust belt of Utah Symposium: Utah Geological Association Publication 10, p. 13-30.

1983, Overthrusts and salt diapirs, central Utah, in Miller, D.M., Todd, V.R., and Howard, K.A., eds., Tectonic and stratigraphic studies in the eastern Great Basin region: Geological Society of America Memoir 157, p. 45-59.

1986, Potential geologic hazards near the Thistle landslide, Utah County, Utah: U.S. Geological Survey Open-File Report 86-119, $17 \mathrm{p}$.

1987, Implications of deformation along the east flank of the Charleston-Nebo thrust plate, central Utah: U.S. Geological Survey Professional Paper 1170-F, p. F1-F29.

1988, Potential geologic hazards near the Thistle landslide, Utah County, Utah: Association of Engineering Geologists Bulletin, v. XXV, no. 1, p. 83-94.

1992, Paired, facing monoclines in the Sanpete-Sevier Valley area, central Utah: The Mountain Geologist, v. 29, no. 1, p. 5-17.

Witkind, I.J., and Hardy, C.T., 1984, The Arapien Shale of central Utah-A dilemma in stratigraphic nomenclature: U.S. Geological Survey Bulletin 1537-A, p. A5-A20.

Witkind, I.J., and Marvin, R.F., 1989, Significance of new potassium-argon ages from the Goldens Ranch and Moroni Formations, Sanpete-Sevier Valley area, central Utah: Geological Society of America Bulletin, v. 101, p. 534-548.

Witkind, I.J., and Page, W.R., 1984, Origin and significance of the Wasatch and Valley Mountains monoclines, Sanpete-Sevier Valley area, central Utah: The Mountain Geologist, v. 21, no. 4 , p. $143-156$.

Witkind, I.J., and Sprinkel, D.A., 1982, Road log, Salt diapirism in central Utah, in Nielsen, D.L., ed., Overthrust belt of Utah Symposium: Utah Geological Association Publication 10, p. 315-330.

Witkind, I.J., Standlee, L.A., and Maley, K.F., 1986, Age and correlation of Cretaceous rocks previously assigned to the Morrison(?) Formation, Sanpete-Sevier Valley area, central Utah: U.S. Geological Survey Bulletin 1584, 9 p.

Witkind, I.J., and Weiss, M.P., 1991, Geologic map of the Nephi $30^{\prime} \times 60^{\prime}$ quadrangle, Carbon, Emery, Juab, Sanpete, Utah, and Wasatch Counties, Utah: U.S. Geological Survey Miscellaneous Investigations Map I-1937.

Witkind, I.J., Weiss, M.P., and Brown, T.L., 1987, Geologic map of the Manti $30^{\prime} \times 60^{\prime}$ minute quadrangle, Carbon, Emery, Juab, Sanpete, and Sevier Counties, Utah: U.S. Geological Survey Miscellaneous Investigations Map I-1631.

Young, G.E., 1976, Geology of Billies Mountain quadrangle, Utah County, Utah: Brigham Young University Geology Studies, v. 23 , pt. 1 , p. $205-280$. 


\section{INDEX}

[Italic numbers refer to illustrations]

A

Aerial views of east flank Gunnison Plateau 39 Aggie Creek ...................................................92 Alignment between faults and folds .............130 Alternative interpretations ("Redmond Silver Mine") ............................ 136 Ancestral course of Willow Creek .......... 29, 31 Ancestral San Pitch River ..............................224 Ancestral Sevier Lake ......................................2 24 Ancestral Sevier River ..................................24 Ancestral surface, geologic pattern ......127, 128 Ancestral Willow Creek .................29, 109, 125 Ancestral Willow Creek area ..... 20, 41, 51-55 $67,100,119,134,135$

Ancient Ephraim fault .................................23 Angular unconformities .................11, 135, 137 Anhydrite ...........................................18, 135

Anomalous depositional thinning .............57, 63 Anschutz Corporation's Monroe Fee

No. 1 well..................................... 102

Arapien basin ................ 7, 11, 23, 25, 131, 133

Arapien deformation ...................................... 86

Arapien embayment ........................................223

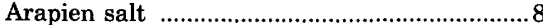

Arapien Shale ...................................... 16-27

Age ...................................................... 25

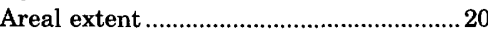

Aspects .................................................... 17

Contact relations ...................................... 19

Contained salt .......................................23

Deformed beds .........................................28

Depositional age ..............................25, 135

Geologic aspects....................................... 18

Gypsum in...............................18, 19, 135

Intrusive aspects .........................27, 30, 85

Lithology ............................................18, 23

Lower contact ........................................ 19

Nomenclature

Oil potential..............................................133

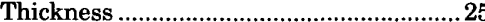

Upper contact .........................................20

Arapien sill.

Arapien Valley .......................................37, 38

Argonaut-Federal well ....................23, 24, 134

Autochthonous plate ...............................12, 13

Axtell Formation ...................................29, 55

Barton No. 1 well, Placid Oil Company..........25

Base-metal deposits ........................................ 138

Basement rocks ............................................... 11

Basin and Range province .............2, 8, 11, 135

Bennie Creek area................ 104, 105, 106, 107

Billies Mountain ............................................. 84

"Billies Mountain" area................. 29, 84, 85, 86

Birch Creek ...................................................74

Birdseye ……............................................. 92

Black Canyon ..................................... 104, 111

Block faulting ................................................. 37

Book Cliffs

132
Bouguer gravity anomaly map .....................103 Boundary Ridge Member of Twin Creek

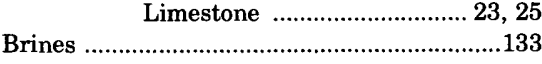

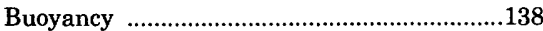

C

Calcite

Canyon Mountains …....................... 11, 21, 23

Carmel Formation ................................. 20, 21

Castle Valley ......................................... 9, 132

Causative forces of deformation....................137

Cedar Hills ........................................ 8, 10, 81

Cedar Mountain Formation ....3, 18, 50, 75, 77 $86,93,95,96,109,111,124$

Cedar Mountain road

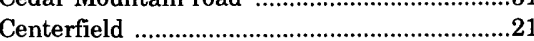

Charleston thrust fault........................................8

Charleston-Nebo overthrust ...........................101

Charleston-Nebo thrust fault ................... 8, 9, 69

Charleston-Nebo thrust plate .......... 12, 20, 21 $29,38,69,70,74,75,81,83$, $92,93,104,105,132,134,138$

Chevron U.S.A.

Chriss Canyon well ...........................24, 24

Salina Unit No. 1 well ...............................24

Chicken Creek area ................... 18, 19, 20, 134

Chriss-Mellor graben ................................ 6, 76

Christianburg ..................................................4

Clear Creek area ...........................................133

Code of Stratigraphic Nomenclature ..............16

Collapse of diapiric folds ................ 8, 119, 120

Collapse structure ................................ 120, 121

Colorado Plateaus province ......... 2, 8, 9, 11, 135

Colton Formation ......................29, 51, 63, 86 $98,99,109,137$

Complex structural relations (Sevier Bridge Reservoir diapiric fold) ...............61

Conduit for diapiric sediments .......................129

Contained salt, Arapien Shale ........................223

Cordilleran geosyncline .......................................11

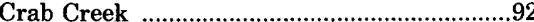

Craton, Paleozoic …...........................................11

Crazy Hollow Formation .............29, 35, 51, 55

$63,99,100,124$

Cross section of typical diapiric fold ............128

Crustal extension .........................................138

Cuesta north of Redmond ........................ 31, 33

Curtis Formation

....18

D

Dairy Fork graben .......................38. 96, 97, 98

Deformed gravels near Gunnison

Reservoir...................................................61

Delta .................................................23, 24

Depositional age (of Arapien Shale) ................25

Depositional stage (of diapiric

episode) .....

124,137

Depositional thinning ...............................63, 76

$107-117,119,136$
Pole Creek diapiric fold ...........................111 Sanpete-Sevier Valley diapiric fold ....... 109 Sevier Bridge Reservoir diapiric fold... 109-111

Thistle Creek diapiric fold ......................111 Diagrammatic cross sections of Red Rocks area ............................................... 45

Diagrammatic sketches of Red Canyon area, Valley Mountains.........................68 68

Diapiric activity .............................................. 131 Diapiric core ....................... 12, 13, 37, 38, 130 Diapiric deformation in Thistle area .............. 92 Diapiric episodes .. 124, 126-127, 129, 131, 137 Diapiric folds (salt-cored anticlines) .......... 3, 12, $13,21,25,28,37,57,67,93,102,105$, $108,117,119,124,125,129,130$, $131,134,135,136,137,138$ Collapse ............................... 119-121 Cross section ............................... 13 Distribution pattern ...................... 36 Growth .................................117-119 Localization .......................... 129-131

Diapiric processes Causative forces ................... 129-131 Cyclical aspects ............................ 129 Geologic pattern.................. 125-129

Diapiric shale ............................................... 12

Diapiric sheath .......................................12, 13

Diapiric stage ..................................... 124, 129

Diapiric stages and episodes ....................... 124

Diapiric structures ................................. 18, 27

Diapirism ............................................. 27-29

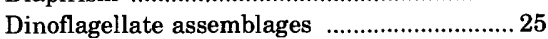

Disturbed zone ...................................... 11, 135

Dixel Resources well ........................................ 25

Dog Valley ...................................................... 9

Dome near ancestral Willow Creek ................29

Dry Canyon ...................................................... 28

Dry Hollow ........................................81, 83, 96

Dry Hollow diapiric fold ...............38, 81, 83, 95

Development................................... 86, 87 Dry Mountain .............................. 107, 118, 119

Dynamic ancestral high ................................ 108

Dynamic barriers ......................................... 136

East Fork of Sanpete Valley .....................98, 99 East Gunnison monocline ......................51, 124

East Tintic Mining District .......................... 135

East Tintic Mountains .................................. 135

Eastern Sevier Valley ....................................... 33

Economic implications of diapirism ............. 132

Elongate salt structures ................................... 37

Elsinore ...............................................21, 23

Emery Sandstone Member of the Mancos Sha

Emplacement ages of the Arapien

Shale....

133

Entrada Sandstone

25,135

Ephraim

38,98 
Erosional escarpment .............9, 10, 21, 29, 84, $92,93,104$ ErosionaI stage of diapiric episode ....... 124, 137 Escarpment fault ............................................ 76 Evaporites .......................................................... 13

Extensional tectonism ................................... 35

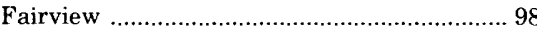

Fairview diapir(?) ................................. 98, 99 Fairview diapiric(?) fold .................... 38, 98-100 Fault plane used as conduit................. 130,131

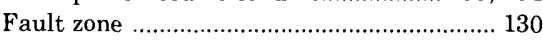

Fayette ……...................................... 38, 130

Ferron Sandstone Member of the Mancos Shale ........................... 133

Flagstaff Limestone ....... 20, 29, 41, 45, 51, 53, $62,85,92,93,98,101,107$ $109,111,124,128,137$

Footes Canyon .......................................... 69, 81 Footes Canyon diapiric(?) fold ..........21, 38, 75, $81-83,105,107$

Fountain Green …….............................. 38, 41

Freedom .......................................................... 38

\section{G}

G-24 well (Union Oil Company) .................... 98 Gardner Canyon …................................... 70, 74 Gardner Canyon-Red Canyon area .............. 134 General stratigraphy .................................... 12-16 Geologic maps of areas discussed in the report................................................ 7

Geologic pattern ..........

Geologic relations

Along both flanks of Gunnison Plateau 123

Near Middle Fork Pole Creek.................... 80

Near "Redmond Silver Mine" ................. 136

Geology near

Black Canyon....................................110, 111

Dry Mountain ...................................118, 119

Head of Payson Canyon..............................116

Head of Santaquin Canyon......................113

Red Lake .................................................... 115

Wales, Utah..................................... 52

Geology of

Ancestral Willow Creek Area ................... 58

Dry Hollow area ………………………... 84

Hjorth Canyon area................................... 95

Little Clear Creek area ..................... 96, 97

Pole Creek-Hop Creek area, Cedar Hills........................ 77, 78

Red Rocks area ........................................ 42

Salt Creek area ..................................... 108

Sixmile Creek Canyon area ..................... 46

Thistle area ………….................. 88, 89, 90 Giraffe Creek Member of

Twin Creek Limestone ............. 19

Goldens Ranch Formation .......67, 75, 101, 124

Gordon Creek well ............................................ 21

Grabens ……................................. 11, 21, 76

Gravity data ....................................... 102-104

Great Basin Section of Basin and

Range province ...................... 11, 132

Great Salt Lake ............................................... 24

Great Western Salt Company .......................... 23

Greater Scipio Valley ....................................... 101

Green River Formation .........20, 23, 29, 31, 84 $92,96,98,99,100,109,113,117,135,137$ Growth and collapse of diapiric folds ....117-121
Gulf Coast

21, 38, 41, 57,102,130

Gunnison Plateau (San Pitch Mountains)..... 10 $11,18,19,21,24,27,28,29,37,38,41$, $48,50,69,75,76,77,81,98,104,109$ $121,123,124,128,130,132,134$

Gunnison Reservoir area ..... 41, 55-57, 61, 125

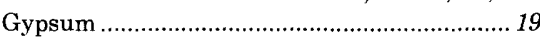

Gypsum Spring Member of Twin Creek Limestone . $\ldots 19,23$

\section{$\mathrm{H}$}

Halite (salt) ......................................................... 24 Halo-kinesis ............................................25, 129

Halo-tectonism ……………………..........25, 130

Hanson Oil Corporation's Moroni

A-1 well .......................................... 132

Hanson wells ..................................................... 25

High-saline conditions, Arapien Shale .......... 133

Hingeline (Paleozoic) .................................. 11, 131

Hjork Creek dome ............................................. 93

Hjorth Canyon area..............................93, 95, 96

Hjorth Canyon diapiric fold .................38, 93-96

Hjorth Canyon salt diapir ...............................95

Hogbacks in eastern Sevier Valley ................... 33

Hop Creek ...............................................81, 82

Hop Creek Ridge .........................................81, 82

Howard 1-A WXC well (Placid Oil Company) .................................24, 101

Hydraulic car jack (analogy)..............................22

\section{I}

Index map of central Utah

Indian Hollow

Indianola ............................... 8, 9, 21, 38, 93, 98 Indianola Group .......29, 41, 50, 57, 62, 75, 77 , $81,83,93,95,96,109,121,124,129,137$ Ingram Canyon …………………………........ 74 Intrusive sedimentary beds .......................12, 27 Intrusive stage of diapiric episode ........124, 137 Iranian diapirs .................................................... 24 Isoclinal fold, Red Rocks area ...........................42

Isopach map of salt deposits............................24

\section{J}

J.W. Irons well No. 1 132 Japanese Valley .......................................38, 101 Joes Valley graben ....................................... 119 Juab .................................................8, 19, 102 Juab County ..................................................... 20 Juab Valley ........................................9, 24, 69, $100,102,104,121,124$

Jurassic marginal basin ...................................2

K

KOA Campground area $18,77,81$

Lake Bonneville, ancestral ...............................24

Lake Fork ................................................ 83, 98

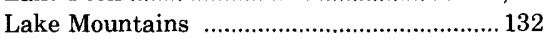
Landslide and earthflow phenomena ...............99 Leamington trans-current fault ......................... 9 Leeds Creek Member of Twin Creek Limestone ................... 19, 20, 23, 25 Levan ................................. 9, 21, 69, 104, 134
Levan area .................................................... 104

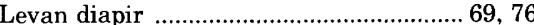
Levan diapiric core ................................ 69, 74 Levan diapiric fold ................21, 38, 57, 69-70, $74,75,76,77,81,104,130$

Levan Unit 1 well (Standard Oil of California)

69,134

Linear upwarps .......................................... 12

Little Clear Creek ........................38, 95, 96, 98

Little Clear Creek diapiric fold .............. 38, 95 ,

96-98, 129

Little Salt Creek $24,69,75$ Loafer Mountain ......... 92, 104, 107 Locality file (Index map of central Utah).... 6-7 Localization and causative forces ............... 129 Long Ridge ................................................ 100

\section{M}

Major fault zones ....................................... 130 Major test wells in central Utah .................. 26 Mancos Shale .............................. 132, 133, 134 Oil potential ............................................ 132 Manning Canyon Shale ...................... 132, 133 Oil potential ......................................... 132 Manti .....................................21, 38, 99, 132 Maple Canyon area .................................... 128 Maturation level .......................................... 133 Mayfield .................................... 18, 33, 38, 57 Mesocordilleran anticline ............................... 23 Micrite, Arapien Shale ................................. 18 Middle Fork Pole Creek ....... 20, 77, 80, 81, 111 Middle Jurassic (Callovian) (Twist Gulch Formation) (.................................... 18

Middle Rocky Mountains province .................. 8 Milburn .................................................. 9, 98

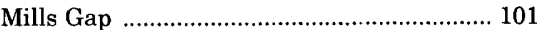

Mineral deposits ......................................... 135

Minor structures ............................................. 29

Mobilization of plastic mudstone beds ............ 3

Mona .................................................. 9, 132 Monoclines .................................. 121-124, 137 Paired, facing ............................... 121-124 Monroe 13-7 well (Placid Oil Co.) ............ 25, 69 Monroe Fee No. 1 well (Anschutz Corp.) ..... 102 Mormon temple in Manti ............................... 99 Moroni .............................................. 38, 93, 132 Moroni AX-1 well (Hanson Oil Corp.) ........ 132 Moroni Formation ........................ 75, 77, 81, 84, $92,95,96,124,137$

Moroni wells ........................................... 25, 41 "Mother bed" of salt ............................ 105, 129 Mount Nebo ..................................................... 2 Mount Pleasant ................................................. 98 Multiple episodes of orogeny ............................ 3 Multiple episodes of salt diapirism ............... 13

\section{$\mathrm{N}$}

Navajo Sandstone (Nugget Sandstone) ......... 19, 29,74

Nebo Loop Road ............................................ 77 Nebo thrust fault ............................................ 8 Nephi ........................ 8, 9, 18, 24, 70, 81, 130 Ninemile Reservoir ................................ 35, 37 North American Stratigraphic Code ............. 16 North Fork Salt Creek .......................... 18, 24 North Horn Formation .... 29, 38, 76, 84, 85, 86, $92,93,95,96,98,107,109,111,124,137$ North San Pitch River Valley diapir ....... 98, 99 
Northeast flank Valley Mountains ................62

Northern Tunisia, salt structures.................129

Nugget Sandstone (Navajo Sandstone).....19, 92

o

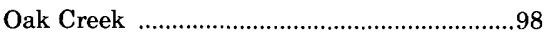
Oil and gas, accumulation of ..................16, 132 Oil and gas, source beds.............................132 Oquirrh Group .........................................70, 74

Orogenic forces ..........................................29

Osiris Tuff .................................................... 30

Overthrust belt ........................................... 134

\section{$\mathbf{P}$}

Painted Rock Canyon Paired, facing monoclines ............100, 121-124 Paleo-high ...................... 81, 83, 92, 113, 117 Paradox Basin ................. 7, 121, 129, 130, 131 Paxton No. 1 test well

(Placid Oil Company) ....................21

Pavant Range............................. 11, 21, 23, 101

Payson Canyon area........ 21, 104, 105, 107, 116 Phillips Petroleum Company's

Price "N" Well ............ 24, 25, 41, 132

Photographic overviews near erosional escarpment ...........................106, 107

Photographs of Thistle area ..........................90

Physiographic provinces in central Utah ........3

Piercement structures ...................................12

Pigeon Creek ............................................19, 134

Pigeon Creek area .........................................69

Placid Oil Company

Howard 1-A WXC well ....................24, 101

Monroe 13-7 well ...............................25, 69

Paxton No. 1 test well...............................21

WXC-USA 1-2 well ...............................102

Pole Creek area .........................................77, 81

Pole Creek diapiric fold .............................21, 38,

$69,77-81,83,111$

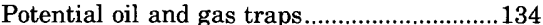

Overthrust belt......................................134

Pre-salt strata...................................134

Salt-bearing and younger strata ............133

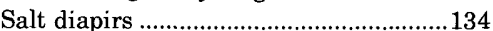

Pre-salt beds ........................ 16, 133, 134, 136

Preuss Sandstone ..........................................21

Price "N" well (Phillips Petroleum

Company).................. 24, 25, 41, 132

Price River and North Horn sequence ....45, 62

Price River Formation ................. 9, 38, 41, 45, $50,67,75,109,111,121,137$

Provo ........................................... 9, 23, 83

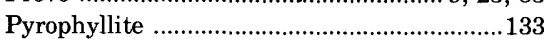

$\mathbf{R}$

Rectorite ...................................................... 133 Red Canyon area

(Southern Wasatch Range) ......... 20, $57,63,70,74,75,101,111,119$, $123,124,127,128$

Red Canyon area, Valley Mountains ............63,

$66,68,99$

Red Knolls ...............................................30, 137

Red Knolls area ................................................30

Red Lake ....................................104, 107, 115

Red Rocks area

(Christianburg) ..........28, 41, 45, 50, $51,75,117,124,127,128$
Red Rocks-Sixmile Canyon area ......41, 51, 55 Redmond ..................... 18, 21, 23, 24, 30, 31, $57,67,102,111,130,135,137$

Redmond diapiric fold .................21, 31, 38 $57,67,113,130$

Redmond Hills anticline ...................... 57, 113

"Redmond Silver Mine"........................135, 136

Rees Flat .............................................. 74, 75

Regional lateral compression ........................ 138

Reservoir beds, oil and gas............................ 132

Rich Member of the Twin Creek Limestone.

... 19

23,25

Richfield ..................................21, 38, 102, 130

Rim syncline .

..... 129

Rock salt (halite) ................................ 13, 18

Round Valley ......................................21, 101

\section{$\mathrm{S}$}

St. George ............................................... 3 Salina ..... 18, 20, 23, 24, 30, 33, 38, 51, 57, 101

Salina Canyon .............................................. 23

Salina Creek Canyon ................................. 9, 113

Saline basin ............................................. 11, 131

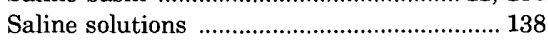

Salt (halite) ......................................... 119, 135

"Salt anticlines" (salt-cored anticlines) ..........2, 37,129

Salt-bearing and younger strata ..........133, 136 Salt-cored anticlines (diapiric folds) ................ 3, $12,20,131$

Salt cores .................................................... 12 Salt Creek ..................... 18, 21, 24, 69, 81, 104 Salt Creek Canyon .........................18, 21, 107 Salt Creek Fanglomerate ............................ 77 Salt diapir .................... 12, 13, 16, 23, 24, 25, $45,117,119,124,129,131,135,138$

Salt diapirism ...............................3, 8, 76, 135 Salt diapirs ...................12, 16, 25, 119, 135, 138 Salt-generated diapiric folds ........................... 3

Salt-generated structures ....................... 3, 105

Salt Spring Creek............................................ 24

Salt-cored dome ............................................ 12

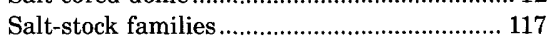

Salt stock (salt diapir) ................................. 117

Salt stocks................................................... 25

Salt structures................................................. 8

Salt structures in northern Germany.......... 129

Salt structures in northern Tunisia.............. 129

Salt walls ............................................... 12, 102

San Pitch Mountains (Gunnison Plateau) ..... 10

San Pitch River ................................... 9, 10, 57

San Rafael Group ................................. 18, 20

San Rafael Swell .......................................... 132

Sanpete County ,.............................................. 23

Sanpete-Sevier rift ........................................ 23

Sanpete-Sevier Valley and

Redmond anticlines

113

Sanpete-Sevier Valley anticline............... 29, 38

$111,113,115$

Sanpete-Sevier Valley area ...... 3, 9, 12, 20, 37, $55,76,111,115,124,137$

Sanpete-Sevier Valley diapiric fold ........21, 29, $38-57,67,98,109,111,113$,

$129,130,131,134$

Sanpete-Sevier Valley salt diapir.....55, 56, 132

Sanpete Valley ........................ 8, 9, 21, 38, 48 , $57,62,98,102,109,124,132$

Sanpete Valley embayment ......................... 132

Santaquin ........................................... 9, 105

Santaquin Canyon ....................... 104, 107, 113

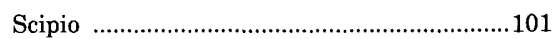

Scipio Lake ................................................... 111

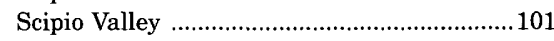

Scofield Reservoir ............................................21

Seismic reflection profiles ............................... 8

Seismic surveys ................................................

Selenite crystals in Arapien Shale .................18

Sevier Bridge Reservoir (Yuba Lake) ...........101

Sevier Bridge Reservoir area........... 57, 69, 102

Sevier Bridge Reservoir diapiric fold .............38, $57-69,109,111,129,131$

Sevier Bridge Reservoir salt diapir . 63, 69, 102

Sevier County, Utah .......................20, 23, 135

Sevier Desert ...................................................23

Sevier fault zone .......................................... 130

Sevier orogeny ...........................................35, 76

Sevier River ............................................ 101

Sevier thrusting .............................................55

Sevier Valley ........................8, 19, 21, 30, 37, $38,101,102,104,121,124,130$

Side Canyon ..................................................98

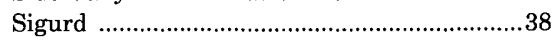

Sixmile Canyon .......99, 109, 119, 121, 123, 127

Sixmile Canyon area ...................... 41, 45, 48,

$62,109,124,127$

Sixmile Canyon Formation ........................... 127

Sixmile Creek canyon ........................29, 48, 50

Skinner Peaks ..........................................75, 76

Skinner Peaks area ..................................75, 81

Sliderock Member of Twin Creek Limestone......................... 19, 23, 25

Small-scale features of Arapien Shale (photographs)..................................33

Smiths Reservoir .........................................98

Soldier Creek ..........................9, 83, 84, 85, 86

Soldier Creek Canyon ......................................83

Source rocks (oil and gas) ............................. 132

South Valley ....................................................101

South wall of Red Canyon (Southern

Wasatch Range) ...........................76

Southern Wasatch Range ........ 8, 9, 70, 105, 107

Southwest flank of the Sevier Bridge Reservoir diapiric fold .................64

Spanish Fork Canyon ....................... 9, 85, 86

Spanish Fork River ................................84, 92

Standard Oil of California Levan unit 1 well..............................69, 134

State No. 1 well

Static load ........................................................ 138

Static topographic high ...............................108

Sterling ...........8, 18, 23, 28, 29, 38, 41, 57, 111

Stratigraphy .........................................12-26

Strip-thrust fault ...................................35, 135

Structural and stratigraphic traps ...............132

Structural complexity and diapiric folds .........63

Structural pattern of central Utah ...............125

Structural traps (oil and gas) ........................133

Summerville Formation .............................. 18

\section{$\mathrm{T}$}

Taylor Fork ................................................104

Taylor Fork area .........................................107

Temple Hill, Manti ...................................99, 100

Tertiary thrusting ..............................................37

Test wells in central Utah.............................26

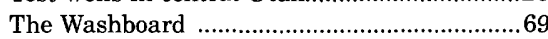

Thickness of salt ............................................ 24

Thistle $8,9,19,20,21$

$23,29,81,83,111,117$

Thistle area ..........83, 84, 92, 93, 107, 111, 134

Thistle Canyon fault 
Thistle Creek $.84,86,92,104,107$ Thistle Creek diapiric(?) fold ................. 21, 38, $83-93,104,105,107,111$

Thistle landslide ……………………...... 29, 86 Transition zone .................................. 2, 11, 131 Twelvemile Canyon Member of the Arapien Shale. 16,27 Twelvemile Creek .........................................5 57

Twin Creek Limestone ................ 19, 20, 23, 29, $69,70,71,74,86,91,92,119,133$

Boundary Ridge Member

Giraffe Creek Member ................................... 19

Gypsum Spring Member .......................... 19

Leeds Creek Member .................................. 19

Rich Member.......................................... 19

Sliderock Member.......................................... 19

Watton Canyon Member ........................... 19

Twist Gulch Formation .........16, 18, 20, 50, 51 , $77,86,93,95,96,111,117,124,137$

Aspects (photographs) ............................. 17

Thickness .................................................... 18

Twist Gulch Member of Arapien Shale .......... 16

Uinta Mountains ................................... 23, 138

Union Oil Company's No. G-24 well............... 98

Unnamed hill near Ninemile Reservoir.......... 35

USGS Professional Paper 1170-F …............ 104

U.S. Highway 6 and 89 .................................... 29

Utah, central, index map ................................. 4

Utah, central, physiographic provinces............. 3

Utah Lake

132
Utah State Highway 132 .

Utah Valley 101

V

V

Valley Mountains .................. 10, 21, 23, 24, 27, $30,38,57,61,67,101,102$ $109,111,117,119,123,124,127,128$ Valley Mountains diapiric(?) fold ...38, 101-102 Valley Mountains monocline ..................63, 69,

Vertical aerial photographs of $98,99,101,119,121$

Views Temple Hill area, Manti.............. 100

Along east flank Dry Mountain ..... 106, 107 Along west valley wall of Thistle Creek 106,107

In Salt Creek Canyon.....................106, 107 Near head of Bennie Creek............. 106, 107 Near head of Dry Hollow............................ 86 Near head of Payson Canyon................... 106 Near Red Lake ................................. 106, 107 Ancestral Willow Creek area ....................57 Volcanic gravels of Gilliland (1948) ................. 30 V-shaped dissolution synclines ........................121 V-synclines 121

\section{$\mathrm{W}$}

Wales ….................................121, 132, 134

Wales Canyon ..................................................50

Wales Gap ......................41, 50, 55, 57, 98, 109
Wasatch and Valley Mountains

monoclines

Wasatch fault zone ................... 9, 11, 105, 130

Wasatch monocline .......... 9, 37, 48, 51, 62, 64, $98,99,100,101,119,121,124$

Wasatch Plateau .......... 8, 9, 21, 23, 38, 48, 51, $76,99,101,109,119,123,132,133$

Wasatch Range 8,10

Watton Canyon Member of Twin Creek Limestone...... 19, 23, 25

West Fork of Sanpete Valley ........................... 98

West Gunnison monocline .......................69, 75,

$76,121,124$

West Hills ................... 9, 21, 24, 100, 101, 121

West Hills diapiric(?) fold ............... 38, 100-101

West Hills monocline .......................... 121, 124

Western Interior of the United States .......... 37

White Hills ..................................18, 37, 51, 57

Willow Creek ................................................. 51

Willow Creek gap .............................. 41, 51, 53

Willow Creek road .................................... 53, 55

Y

Yuba Dam $.23,62,67,69,101$

\section{Z}

Zechstein salt ...................................... 12, 102

Z-fold

Manuscript approved for publication March 13, 1992

Published in the Central Region, Denver, Colorado

Edited by Lorna Carter

Photocomposition by Marie F. Melone

Graphic design by Patricia L. Wilber

Cartography by Henry Williams

U.S. GOVERNMENT PRINTTNG OFFICE: 1994-673-046/86056 


\section{SELECTED SERIES OF U.S. GEOLOGICAL SURVEY PUBLICATIONS}

\section{Periodicals}

Earthquakes \& Volcanoes (issued bimonthly).

Preliminary Determination of Epicenters (issued monthly).

\section{Technical Books and Reports}

Professional Papers are mainly comprehensive scientific reports of wide and lasting interest and importance to professional scientists and engineers. Included are reports on the results of resource studies and of topographic, hydrologic, and geologic investigations. They also include collections of related papers addressing different aspects of a single scientific topic.

Bulletins contain significant data and interpretations that are of lasting scientific interest but are generally more limited in scope or geographic coverage than Professional Papers. They include the results of resource studies and of geologic and topographic investigations; as well as collections of short papers related to a specific topic.

Water-Supply Papers are comprehensive reports that present significant interpretive results of hydrologic investigations of wide interest to professional geologists, hydrologists, and engineers. The series covers investigations in all phases of hydrology, including hydrology, availability of water, quality of water, and use of water.

Circulars present administrative information or important scientific information of wide popular interest in a format designed for distribution at no cost to the public. Information is usually of short-term interest.

Water-Resources Investigations Reports are papers of an interpretive nature made available to the public outside the formal USGS publications series. Copies are reproduced on request unlike formal USGS publications, and they are also available for public inspection at depositories indicated in USGS catalogs.

Open-File Reports include unpublished manuscript reports, maps, and other material that are made available for public consultation at depositories. They are a nonpermanent form of publication that may be cited in other publications as sources of information.

\section{Maps}

Geologic Quadrangle Maps are multicolor geologic maps on topographic bases in $71 / 2$ - or 15-minute quadrangle formats (scales mainly $1: 24,000$ or $1: 62,500$ ) showing bedrock, surficial, or engineering geology. Maps generally include brief texts; some maps include structure and columnar sections only.

Geophysical Investigations Maps are on topographic or planimetric bases at various scales, they show results of surveys using geophysical techniques, such as gravity, magnetic, seismic, or radioactivity, which reflect subsurface structures that are of economic or geologic significance. Many maps include correlations with the geology.

Miscellaneous Investigations Series Maps are on planimetric or topographic bases of regular and irregular areas at various scales; they present a wide variety of format and subject matter. The series also includes 7 1/2-minute quadrangle photogeologic maps on planimetric bases which show geology as interpreted from aerial photographs. The series also includes maps of Mars and the Moon.
Coal Investigations Maps are geologic maps on topographic or planimetric bases at various scales showing bedrock or surficial geology, stratigraphy, and structural relations in certain coal-resource areas.

Oil and Gas Investigations Charts show stratigraphic information for certain oil and gas fields and other areas having petroleum potential.

Miscellaneous Field Studies Maps are multicolor or black-andwhite maps on topographic or planimetric bases on quadrangle or irregular areas at various scales. Pre-1971 maps show bedrock geology in relation to specific mining or mineral-deposit problems; post-1971 maps are primarily black-and-white maps on various subjects such as environmental studies or wilderness mineral investigations.

Hydrologic Investigations Atlases are multicolored or black-andwhite maps on topographic or planimetric bases presenting a wide range of geohydrologic data of both regular and irregular areas; the principal scale is 1:24.000, and regional studies are at 1:250,000 scale or smaller.

\section{Catalogs}

Permanent catalogs, as well as some others, giving comprehensive listings of U.S. Geological Survey publications are available under the conditions indicated below from USGS Map Distribution, Box 25286, Building 810, Denver Federal Center, Denver, CO 80225. (See latest Price and Availability List.)

"Publications of the Geological Survey, 1879-1961" may be purchased by mail and over the counter in paperback book form and as a set microfiche.

"Publications of the Geological Survey, 1962-1970" may be purchased by mail and over the counter in paperback book form and as a set of microfiche.

"Publications of the U.S. Geological Survey, 1971-1981" may be purchased by mail and over the counter in paperback book form (two volumes, publications listing and index) and as a set of microfiche.

Supplements for 1982, 1983, 1984, 1985, 1986, and for subsequent years since the last permanent catalog may be purchased by mail and over the counter in paperback book form.

State catalogs. "List of U.S. Geological Survey Geologic and Water-Supply Reports and Maps For (State)," may be purchased by mail and over the counter in paperback booklet form only.

"Price and Availability List of U.S. Geological Survey Publications," issued annually, is available free of charge in paperback booklet form only.

Selected copies of a monthly catalog "New Publications of the U.S. Geological Survey" is available free of charge by mail or may be obtained over the counter in paperback booklet form only. Those wishing a free subscription to the monthly catalog "New Publications of the U.S. Geological Survey" should write to the U.S. Geological Survey, $582 \mathrm{Na}$ tional Center, Reston, VA 22092.

Note.-Prices of Government publications listed in older catalogs, announcements, and publications may be incorrect. Therefore, the prices charged may differ from the prices in catalogs, announcements, and publications. 
